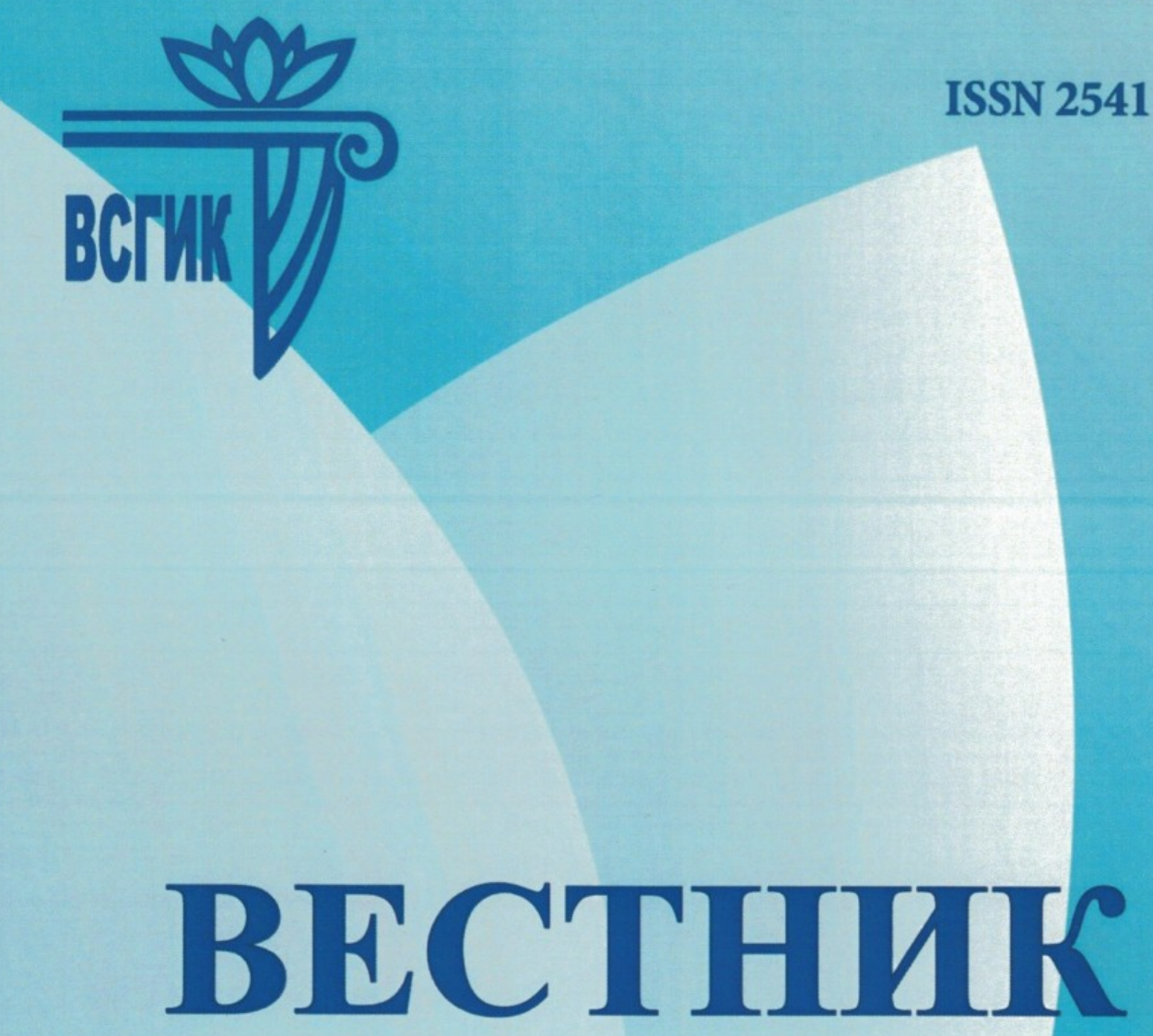

Восточно-Сибирского государственного института культуры 
Министерство культуры Российской Федерации ФГБОУ ВО «Восточно-Сибирский государственный институт культуры»

\section{В Е С Т Н И К \\ Восточно-Сибирского государственного института культуры}

Научный журнал по искусствоведению, культурологии, историческим наукам

\section{№ 3(15)}

Улан-Удэ

Издательско-полиграфический комплекс

ФГБОУ ВО ВСГИК

2020 
Учредитель: ФГБОУ ВО «Восточно-Сибирский государственный институт культуры»

Свидетельство о регистрации

ПИ № ФС 77 - 74824 от 21 января 2019 г.

Федеральная служба по надзору в сфере связи, информационных технологий и массовых коммуникаций

(Роскомнадзор)

\section{Журнал включен в систему РИНЦ}

\section{Редакционная коллегия}

Р. И. Пшеничникова, проф., академик МАН ВШ (гл. редактор); Е. Ю. Перова, кан. эконом. наук, доцент (зам. гл. редактора); И. С. Цыремпилова, д-р ист. наук, проф. (зам. гл. редактора); И. Б. Батуева, д-р ист. наук, проф.; Т. Н. Бояк, д-р социол. наук, проф.; Н. Б. Дашиева, д-р ист. наук, проф.; С. А. Езова, канд. пед. наук, проф.; В. Л. Кургузов, д-р культурологии, проф.; 3. А. Серебрякова, д-р филол. наук, доцент; С. Г. Степанова, канд. пед. наук, доцент; С. П. Татарова, д-р социол. наук, проф.; Е. В. Банзаракцаева, канд. ист. наук, доцент (отв. секретарь); Л. М. Хобракова, канд. филол. наук, доцент; Н. Д. Хосомоев, канд. филол. наук, проф.; А. В. Чебунин, д-р филос. наук, проф.

\section{В Е С Т Н И К Восточно-Сибирского государственного института культуры : научный журнал по искусствоведению, культурологии, историческим наукам. - Улан-Удэ : Издательско-полиграфический комплекс ВСГИК, 2020. - № 3(15). - 172 с.}

Адрес издателя, редакции и типографии ФГБОУ ВО «ВосточноСибирский государственный институт культуры» 670031, Республика Бурятия, г. Улан-Удэ, ул. Терешковой, д. 1. Телефон: (3012) 23-29-83; e-mail: vestnikvsgik@mail.ru

Выход в свет 30.11.2020. 70x108 1/16. Усл. печ. л. 15,05. Уч.-изд. л. 11,12. Тираж 500 экз. Заказ № 2440. Цена свободная.

Отпечатано в Издательско-полиграфическом комплексе ФГБОУ ВО ВСГИК 670031, г. Улан-Удэ, ул. Терешковой, 1.

(C) ФГБОУ ВО «Восточно-Сибирский государственный институт культуры»»), 2020. 
Бадмаев А. Г.

АНТОЛОГИЯ БУРЯТСКОГО КИНО 5

Волобуева Н. В.

КРАТКИЙ СТРУКТУРНО-ИСПОЛНИТЕЛЬСКИЙ АНАЛИЗ

ПРОИЗВЕДЕНИЙ ДЛЯ ЧАНЗЫ КОМПОЗИТОРА ДАРЬИ КОРКИНОЙ 20

Тимошенкова А. М., Кириллова Н. К.

АТРИБУЦИЯ КУКЛЫ ХХ ВЕКА, СПЕЦИФИКА И ПРОБЛЕМЫ

РЕСТАВРАЦИИ

кУЛЬТУРОЛОГИЯ 35

Дементьева В. В.

ФОРМИРОВАНИЕ КУЛЬТУРНЫХ ИНСТИТУТОВ В ГОРОДАХ

ВОСТОЧНОЙ СИБИРИ (ВТОРАЯ ПОЛОВИНА ХІХ - НАЧАЛО ХХ ВВ.)... 35

Бояк Т. Н.

СОЦИОЛОГИЯ МОЛОДЕЖИ В ПРОФЕССИОНАЛЬНОЙ ПОДГОТОВКЕ КАДРОВ ДЛЯ ОТРАСЛИ КУЛЬТУРЫ

Амгаланова М. В., Назаров В. К.

СТАНОВЛЕНИЕ И СОВРЕМЕННОЕ СОСТОЯНИЕ

КУЛЬТУРОЛОГИЧЕСКОГО ОБРАЗОВАНИЯ В РЕГИОНЕ 53

ИСТОРИЧЕСКИЕ НАУКИ 61

Дикий Я. В.

АРХЕОЛОГИЧЕСКИЕ КОЛЛЕКЦИИ В СОСТАВЕ ИСТОРИКО-

КУЛЬТУРНОГО НАСЛЕДИЯ БУРЯТИИ: ПРОБЛЕМА ДЕФИНИЦИЙ. 61

Аюшеева М. В.

ОБЗОР БУРЯТСКИХ РОДОСЛОВНЫХ В ЛИЧНОМ АРХИВНОМ ФОНДЕ Ж.

А. ЗИМИНА (1920-2012)

Немчинова Т. А., Цыремпилова И. С.

«С ЧЕГО НАЧИНАЕТСЯ ВСГИК?»: СТЕНОГРАММА ТОРЖЕСТВЕННОГО ЗАСЕДАНИЯ, ПОСВЯЩЕННОГО ОТКРЫТИЮ ВОСТОЧНО-СИБИРСКОГО БИБЛИОТЕЧНОГО ИНСТИТУТА 
Базарова О. В., Гомбожапов А. Д.

К ВОПРОСУ О СОТРУДНИЧЕСТВЕ МОНГОЛИИ И РЕСПУБЛИКИ

БУРЯТИЯ В СФЕРЕ ВЫСШЕГО ОБРАЗОВАНИЯ

ОБРАЗОВАНИЕ В СФЕРЕ КУЛЬТУРЫ И ИСКУССТВА. 100

Арбатская О. А.

ОТ НАУЧНО-ТЕХНИЧЕСКОЙ ИНФОРМАЦИИ ДО ЦИФРОВИЗАЦИИ В

ОБРАЗОВАНИИ.

Воронцова Л. С., Солнцева Г. Н.

КАФЕДРА ДИЗАЙНА - 15 ЛЕТ ТВОРЧЕСТВА И ВОСПИТАНИЯ

СОВРЕМЕННЫХ СПЕЦИАЛИСТОВ

Ернова О. С.

ЦЕНТР ЗАОЧНОГО И ДОПОЛНИТЕЛЬНОГО ОБРАЗОВАНИЯ: ИСТОРИЯ СТАНОВЛЕНИЯ И РАЗВИТИЯ.

Хобракова Л. М., Шойбонова С. В.

РОЛЬ ОЛИМПИАДНОГО ДВИЖЕНИЯ В РАЗВИТИИ

КОММУНИКАТИВНОЙ КОМПЕТЕНЦИИ СТУДЕНТОВ ВСГИК

\section{Рещиков Н. И.}

ИЗ ИСТОРИИ НАРОДНО-ПЕВЧЕСКОГО ОБРАЗОВАНИЯ В ВОСТОЧНО-

СИБИРСКОМ ГОСУДАРСТВЕННОМ ИНСТИТУТЕ КУЛЬТУРЫ

Маншеева С. Ц.

ИЗ ОПЫТА ТВОРЧЕСКОЙ ДЕЯТЕЛЬНОСТИ СТУДЕНЧЕСКОГО ФОЛЬКЛОРНОГО АНСАМБЛЯ «УЛЬГЭР»

ВЕХИ И СУДЬБЫ

Орлов Л. Г.

ГОДЫ ВО ВСГИКЕ: ГЛАЗАМИ ОЧЕВИДЦА

Дандарон М. Б.

ПРОФЕССОР Г. И. БАЛХАНОВ В НАУКЕ И ОБРАЗОВАНИИ 165

СВЕДЕНИЯ ОБ АВТОРАХ 169 


\section{ИСКУССТВОВЕДЕНИЕ}

DOI 10.31443/2541-8874-2020-3-15-5-19

УДК 791.43.03(571.54)

Бадмаев А. Г.

Badmaev A. G.

\section{АНТОЛОГИЯ БУРЯТСКОГО КИНО THE BURYAT CINEMA ANTHOLOGY}

Молодёжь, посмотрев совсем недавние фильмы бурятских кинематографистов, снятые в середине 2000-х годов, ошибочно утверждает, что это первые фильмы бурятского кинематографа. Отнюдь. Бурятскому кино, без малого, уже сто лет. Просто в последние годы, после долгого затишья, произошёл бум бурятской киноиндустрии. Снято несколько фильмов на разные темы. Чтобы опровергнуть молодость бурятского кино нам пришла мысль написать про антологию бурятской национальной кинематографии.

Young people, having watched the most recent films of the Buryat cinematographers, shot in the mid-2000s, mistakenly claim that those are the first films of the Buryat cinematography. Not at all. The Buryat cinema is almost 100 years. Just in recent years, after a long lull, there has been a boom in the Buryat film industry. Several films on various topics have been shot. To disprove the early age of the Buryat cinema, the idea to write about the anthology of the Buryat national cinematography occurred to me.

Ключевые слова: бурятское кино, история кино, бурятские режиссёры и киностудии.

Keywords: the Buryat cinema, history of cinema, Buryat filmmakers and film studios.

Историю бурятского кинематографа, к которому причастны, так или иначе, наши земляки, можно условно разделить на 2 части: советскую и российскую (новую). Обе очень сильно отличаются друг от друга, как составом актёров, так и жанром самих фильмов.

\section{Советское бурятское кино}

1920-е годы. Первым известным бурятским актёром следует считать Валерия Инкижинова (1895-1973), снявшегося в главной роли в советском фильме «Потомок Чингисхана» (1928) [76], после эмиграции в 1930 году во Францию снялся ещё в 44 кинолентах, в основном французских. До этого Инкижинов снял советский фильм «Расплата» (1926) [32] в качестве режисcëpa.

1950-е годы. После долгого перерыва выходит приключенческий боевик «Случай в тайге» (1954) [26] (реж. Юрий Егоров и Юрий Победоносцев) с народным артистом СССР Гомбо Цыденжаповым (в честь которо- 
го назван Бурятский оперный театр) и Цыреном Шагжиным. Вообще советские режиссёры приглашали бурят играть жителей всех народов Сибири. В 1956 году выходит фильм «Песня табунщика» [57] (реж. Андрей Фролов; сценарист Даширабдан Батожабай) про молодого талантливого певца, отправившегося учиться в Москву. Безусловно, эпохальным фильмом для Бурятии стала военно-историческая драма «Пора таёжного подснежника» (1958) [39] (реж. Ярополк Лапшин) Свердловской киностудии, где снялась целая плеяда бурятских артистов, в основном актёров театра бурятской драмы. Годом позже снимается знаменитый «Золотой дом» (1959) [10] (реж. Владимир Басов; сценаристы: Валентин Ежов, Гомбожап Цыденжапов, Даширабдан Батожабай). В двух последних фильмах описываются события времён Гражданской войны.

1960-1980-е годы. Фильмы Бараса Халзанова (1938-1993) [66] стали классикой бурятского советского кинематографа и вошли в его анналы. Первым его фильмом стала военная короткометражка «Белая лошадь» (1966) [59]. Одним из наиболее известных его фильмов стал «Последний угон» (1969) [60] (полнометражный режиссёрский дебют), в котором одну из главных ролей сыграла молодая Лариса Егорова, а также Буда Вампилов, Дагба Дондуков и др. В картине освещаются события времён Гражданской войны. Военная драма «Горький можжевельник» (1985) [61] также объединила целую плеяду бурятских актёров в одном проекте. В фильме описываются события в тылу во время Великой Отечественной войны. Кроме вышеперечисленных, Барас Халзанов в общем снял более десятка фильмов, снимая для башкир и тувинцев.

Известный советский режиссёр Арья Дашиев (1938-2008) [67] снял три киноленты, внесённых мной в список бурятских: «Три солнца» (1976) [15], «Крик тишины» (1981) [16], «Утро обречённого прииска» (1985) [17]. (Арья Дашиев снимал социальные драмы в условиях народного хозяйства. Во всех его фильмах непременно играл Михаил Елбонов.

Третьим известным режиссёром был Александр Итыгилов (19441990) [68], успевший снять лишь 7 фильмов с 1980 по 1990 гг., в числе которых «Продаётся медвежья шкура» (1980) [33], снятый в Прибайкальском районе Бурятии. Но по-настоящему бурятский фильм, с нашими актёрами, он так и не снял.

1990-е годы. Между делом, стоит отметить актрису и топ-модель Ирину Пантаеву [69], дочь знаменитого композитора Владлена Пантаева, снимавшуюся в советских, американских, итальянских и немецких фильмах, самый яркий из которых «Смертельная битва 2: Истребление» (США, 1997) [40], снятый по мотивам популярной в то время компьютерной игры Mortal Kombat.

\section{Новое бурятское кино}

Бурятское кино возродилось и начало снова сниматься после долгого перерыва. Фильмы сняты в основном в Бурятии, без вмешательства извне и силами полупрофессионалов, а порой и любителей. Подавляющее большинство фильмов снято на собственные деньги режиссёров, сценаристов и продюсеров, впоследствии возвращающихся за счёт проката в кинотеатрах. По- 
мощь государства в производстве «нового бурятского кино» почти отсутствует. Снимаются фильмы разного плана и жанра. От короткометражек до полного метра, мини-сериалы и документальные фильмы.

2006 год. Первой «ласточкой» считается «Первый нукер Чингисхана» (2006) [30] (реж. Саян Жамбалов и Эрдэни Жалцанов), исторический фильм по мотивам «Жестокого века» и «Сокровенного сказания монголов», снятый на бурятском языке. В главных ролях снялись актёры Бурдрама Сэнгэ Ломбоев и Баярто Ендонов. Фильм снят после долгих мытарств и судебных тяжб [77], в основном связанных с материальной составляющей. В данный момент фильм доступен к просмотру на YouTube [31].

2007 год. Режиссёрами Анатолием Баторовым и Асей Колодченко был снят музыкально-молодёжный фильм «Улан-Удэнская история» [11]. В главных ролях сыграли Эдуард Жагбаев - солист бурятского оперного театра и Юлия Семакина - Краса Бурятии-2009.

2008 год. «Улыбка Будды» [21] - короткометражка режиссёра Баира Дышенова [70]. В феврале 2009 года картина получила «Хрустальный медведь» на Берлинском фестивале.

2009 год. Режиссёр Эрдэни Жалцанов выпустил фильм «Эхо» [27] (киностудия «Урга») о молодом человеке, который заблудился по жизни и попадает то в прошлое, то в будушее. В свободное от работы время артисты Бурдрама снялись в новогоднем фильме с элементами мюзикла «Ирония любви или с новым счастьем» [28] (реж. Баярма Жалцанова), показанный по каналу «Тивиком» 31 декабря 2009 г. под названием «Ищите женщину». Фильм-мюзикл снят от души и для души, так сказать, для «своих». На широкие экраны эти фильмы не выходили. Позднее «Ирония любви...» вышла на DVD ограниченным тиражом [78].

2010 год. КВНщики решили не отставать и сняли несколько фильмов, которые вышли в прокат в кинотеатрах гг. Улан-Удэ, Москва, Иркутск, Чита и других, где есть более-менее активные бурятские диаспоры. Первая бурятская комедия «Чайник» (2010) [5] (реж. Жаргал Бадмацыренов, Александр Кузьминов и Евгений Замалиев), снятая на фотокамеру, и вышедшая в прокат в декабре 2010 года, собрала в столице Бурятии и других регионах России кассу, сравнимую с высокобюджетными голливудскими фильмами, вышедшими в то же время в прокат, и даже затмила их. Ажиотаж охватил всю бурятскую молодёжную ойкумену страны. В этом же году режиссёр Солбон Лыгденов [71], ещё один бурятский мувимэйкер, выпустивший рекламный ролик к 350-летию вхождения Бурятии в состав России и ещё множество работ, снял фильм «Золотые шахматы Будды» [41].

Поэтому в 2011 году снято уже 3 наших фильма. В ноябре выходит короткометражка «Наказ матери» («Три слезы матери») (бур. «Эхын гурбан нулимса») [22] - второй фильм Баира Дышенова, отмеченный на кинофестивале в Каннах. В декабре - комедия «Улан-Уdance» [6] (режиссёры творческое трио: Жаргал Бадмацыренов, Александр Кузьминов и Евгений Замалиев). Комедия «На Байкал» [34] (реж. Михаил Козлов и Сергей Никонов) снята летом 2011 г., а в прокат выходит в феврале 2012 года. Качество 
звука оставляло желать лучшего, но в версии всероссийского формата сделали качественную озвучку на деньги Мосфильма.

2012 год. Выходят в свет вторая часть комедии: «На Байкал-2: На абордаж» [35], мини-сериал «На Байкал. Поехали» [36], «Тайна завещания» [12] (реж. Юрий Ботоев) и криминальная драма «Решала» [3] (реж. Роман Асхаев), последний из перечисленных успел стать культовым. В главных ролях сыграли Александр Фролов, Константин Озёров и Мосэ Куртанидзе.

2013 год. В честь Сагаалгана в феврале выходит фильм «Буузы» [7] (реж. Жаргал Бадмацыренов). В марте в кинотеатрах города выходит «Отхончик. Первая любовь» [23] режиссёра Баира Дышенова, в процессе съёмок фильм носил название «Эрхүүдэй», что можно перевести как «баловень», но всё же, по словам самого режиссёра, название решили сделать более популярным для зрителя и фильм приобрёл конечное название. В сентябре в прокат выходит криминальная драма «Шлагбаум» [51] режиссёра Дмитрия Туприна и продюсера Алдара Дугарона (aka Alizan Dze). В октябре выходит иркутско-бурятский фильм «Похабовск. Обратная сторона Сибири» [65] (реж. Юрий Яшников, сценарист Жаргал Бадмацыренов) с участием звёздных актёров. В ноябре выходит вторая часть «Чайника» - «Чайник-2» [8], но успеха первой части кинолента не сыскала. Также в этом году в кинотеатрах показывается остросоциальная драма «Булаг» [42] (реж. Солбон Лыгденов), получившая хорошие отзывы от кинозрителей.

2014 год. В июне выходит документальный фильм «Танец орла» [1] (реж. Виктор и Елена Алфёровы) о многократном чемпионе Европы Баире Омоктуеве [72]. В августе в прокат выходят «Степные игры» [24] режиссёра Баира Дышенова. Творческая команда фильма «На Байкал» снимает ещё одну комедию - «Гастролёры» [47] (реж. Сергей Никонов и Евгений Жамцуев). В июне 2013 года создаётся паблик в социальной сети «Вконтакте», который называется «Аноним 03» [79]. За короткое время паблик становится невероятно популярным, ведь все самые интересные события Улан-Удэ и Бурятии обсуждаются в этом паблике. Даже телевидение и пресса начинают черпать оттуда информацию. Квинтэссенцией популярности становится выпуск одноимённого фильма «Аноним 03» [58] (реж. Александр Фролов). Фильм основан на реальных событиях реальных людей, которые режиссёр почерпнул из ставшего культовым анонимного паблика.

2015 год. В январе в прокат вышла социальная драма «Живи» [52] (реж. Баир Уладаев) об алкоголизме, безработице, самовольных постройках и других социальных проблемах. В августе вышла вторая часть нашумевшего криминального фильма «Решала 2» [4] (реж. Роман Асхаев). В этом же году режиссёры Виктор и Елена Алфёровы снова снимают документальное кино. На этот раз их взор упал на историю буддизма в Бурятии. Проект назван «Земля счастливого учения» [2].

2016 год. В январе выходит социальная драма «Сэржэм» [53] (реж. Баир Уладаев), освещающая культурно-языковые проблемы бурят. Летом 2015-го киностудией «Asia Films» снимается комедия «Байкальские каникулы» [45] (реж. Анастасия Немчинова, Ольга Бутакова, Артём Бурлов), которая вышла в прокат 11 февраля 2016-го. В сентябре с премьерой выходит 
криминальная драма «Убийца» [20] (реж. Батор Доржиев). В ноябре вышла спортивно-криминальная мелодрама «Эластико» [50] (реж. Михаил Расходников; сценаристами выступили квнщики: Жаргал Бадмацыренов, Евгений Замалиев и Александр Кузьминов). Над проектом работала московскобурятская команда и фильм по большей части был снят в Бурятии и вышел в прокат по всей стране. В ноябре того же года выходит в прокат второй московско-бурятский проект в году, драматическая комедия «Прикосновение ветра» [18] (реж. Елена Демидова, Ольга Веремеева). Ещё один (третий) московско-бурятский проект с привлечением звёздных актёров был снят в этом же году - «Стоп! Снято! На Байкал!» [37] (реж. Михаил Козлов).

2017 год. 24 марта вышел короткометражный фильм «Хранители» [54] (реж. Баир Уладаев), про тяжёлую работу врачей и вылеченных пациентов. Самым нашумевшим фильмом года становится криминальная драма «Смерти нет» [48] (реж. Виктор Овчинников). Фильм отражает историю взаимоотношений людей в пору молодёжных криминальных субкультур Улан-Удэ 1970-1980 гг. 6 апреля вышла в прокат детская комедия «Байкальские каникулы 2.0» [46] (реж. Анастасия Немчинова, Ольга Бутакова, Артём Бурлов). 13 июня на канале Тивиком стартовал студенческий комедийный сериал «Зачётная весна» [80] киностудии «Asia Films». Было снято 8 серий по 20 минут. Съёмки проходили в Бурятской государственной сельскохозяйственной академии, главные роли сыграли студенты этого вуза. Сериал также транслировался в Иркутской области и Забайкальском крае.

С 2017 по 2019 гг. Солбон Лыгденов снимает, пожалуй, самую затяжную по съёмкам историческую картину про Великую Отечественную войну, а точнее про 321-ю сибирскую дивизию, участвовавшую в Сталинградской битве 1942 года. Проект получает название «321-я сибирская» [43]. Съёмки ведутся как на территории Бурятии, так и в Иркутской и Волгоградской областях. В актёрский состав входят как бурятские артисты, так и артисты из Германии, Москвы и регионов России. В 2018-2019 гг. режиссёр организовывал предпремьерные показы, но долгожданная премьера постоянно переносится на неопределённый срок и в прокат фильм не может выйти до сих пор.

25 декабря в Национальной библиотеке Республики Бурятия прошла презентация короткометражного документального фильма «Холын харгыда» [29] (реж. Баярма Жалцанова), посвящённого 85-летию со дня рождения бурятской поэтессы Цырендулмы Дондогой [73].

2018 год. В апреле выходит криминальная драма «Головар» [13] (реж. Юрий Ботоев). В сентябре, ко дню города Улан-Удэ, выходят шесть киноновелл, объединённых в один фильм «Улан-Удэ, я люблю тебя!» [49] (режиссёры: Виктор Овчинников, Батор Цыбиков, Батор Доржиев, Баир Цыренов, Арсалан Цыренжапов). В конце октября вышла социальная драма «Дом на Луне» [62] (реж. Батор Цыбиков). Елена Демидова снимает ещё один документальный фильм в Бурятии «Феномен Этигэлова. Загадка Бурятского ламы» [19].

2019 год. В феврале выходит в прокат социально-драматический фильм «На берегу мечты» [55] (реж. Баир Уладаев). В апреле выходит драма 
«Шарнохой - жёлтый пёс» [25] (реж. Баир Дышенов). В мае на Чебоксарском международном кинофестивале короткометражный фильм «Прозрение» [64] (реж. Владимир Ширапов) получает приз «За воплощение образа духовного наследия». 31 октября стартовала криминальная драма «По совести» [63] (реж. Александр Цыренов). В декабре вышел в прокат третий фильм: приквел «Решала. Нулевые» [9] (реж. Жаргал Бадмацыренов и Александр Кузьминов). Картина выходит уже после кончины одного из режиссёров и продюсеров фильма Евгения Замалиева (1979-2019) [74].

2020 год. Зимой режиссёр Солбон Лыгденов снял фильм «Булаг 2. К новой жизни» [44]. Предпремьерный показ прошёл в марте, а в апреле должен был выйти в широкий прокат, но в планы вмешалась пандемия коронавируса. На 2020 год запланированы премьеры ещё нескольких фильмов: драма «Два капитана» [56] (реж. Баир Уладаев); военно-исторической приключенческой фантастики «Золото империи» [14] (реж. Юрий Ботоев); семейная комедия с элементами мистики «Байкальские каникулы 3» [81]. 3апланировано производство фильма «Зуһалан» [38] («Летник») (реж. Баир Уладаев). Кинокомпания «Байкалкино» совместно со студией «Гринбокс» работают над созданием комедийной криминальной многосерийки «Маньячелло».

\section{Послесловие}

Помимо скудного бюджета фильмов и отсутствия государственного финансирования, самой большой проблемой является то, что ни один режиссёр не снимает фильмы на бурятском языке. Исключением является лишь «Первый нукер Чингисхана».

О масштабном развитии республиканской киноиндустрии говорить не приходится. Редкие и непостоянные гранты государства на съёмку или доработку уже снятого материала не позволяют развить бурятское кино в полном масштабе. Снятые на бюджетные деньги (полученные частными киностудиями в условиях сильной конкуренции и скандалов) фильмы совсем не окупаются в прокате.

В бурятском кино нет единства. К ранее созданному Союзу кинематографистов Республики Бурятия под председательством Артёма Бурлова [75; 82] добавилось представительство Союза кинематографистов России в Бурятии, которую возглавил режиссёр Баир Дышенов [83]. Считаю, что настала пора изыскивать средства, чтобы построить съёмочные студии и павильоны. Нельзя дальше развиваться, снимая кино на улице любительскими камерами и монтируя материал у себя дома или в гараже. Нужно более десятка частных киностудий («Байкалкино», «Истоки», «Үндэр», «МонУлаФильмс», «БурятКино», «Азия Фильмс», «Уладай Баяр», «Урга» и др.) попытаться объединить в одну, либо создать государственную киностудию, чтобы она давала стабильный продукт.

\section{Примечания}

1. Алфёров В. Танец орла. URL: https://www.kinopoisk.ru/film/756976/ (дата обращения: 04.06.2020).

2. Алфёров В. Земля счастливого учения. URL: https:/www.kinopoisk 
.ru/film/891379/ (дата обращения: 04.06.2020).

3. Асхаев Р. Решала. URL: http://www.kinopoisk.ru/film/717355/ (дата обращения: 04.06.2020).

4. Асхаев Р. Решала 2. URL: https://www.kinopoisk.ru/film/892585/ (дата обращения: 04.06.2020).

5. Бадмацыренов Ж. Чайник. URL: https://www.kinopoisk .ru/film/580644/ (дата обращения: 04.06.2020).

6. Бадмацыренов Ж. Улан-Удэнцы. URL: https://www.kinopoisk .ru/film/677736/ (дата обращения: 04.06.2020).

7. Бадмацыренов Ж. Буузы. URL: http://www.kinopoisk.ru/film/733142/ (дата обращения: 04.06.2020).

8. Бадмацыренов Ж. Чайник 2. URL: https://www.kinopoisk. ru/film/767124/ (дата обращения: 04.06.2020).

9. Бадмацыренов Ж. Решала. Нулевые. URL: https:/www.kinopoisk .ru/film/1280515/ (дата обращения: 04.06.2020).

10. Басов В. Золотой дом. URL: https:/www.kinopoisk.ru/film/751812/ (дата обращения: 04.06.2020).

11. Баторов А. Улан-Удэнская история. URL: https:/www.kinopoisk .ru/film/802924/ (дата обращения: 04.06.2020).

12. Ботоев Ю. Тайна завещания. URL: http://www.kinopoisk. ru/film/710101/ (дата обращения: 04.06.2020).

13. Ботоев Ю. Головар. URL: https://www.kinopoisk.ru/film/1111862/ (дата обращения: 04.06.2020).

14. Ботоев Ю. В Бурятии завершили съемки фильма «Золото империи» // Восток Телеинформ. URL: https://vtinform.com/news/148/148402/ (дата обращения: 04.06.2020).

15. Дашиев A. Три солнца. URL: https:/www.kinopoisk.ru/film/754813/ (дата обращения: 04.06.2020).

16. Дашиев А. Крик тишины. URL: http://www.kinopoisk .ru/level/1/film/44982/ (дата обращения: 04.06.2020).

17. Дашиев А. Утро обречённого прииска. URL: http://www.kinopoisk. ru/level/1/film/153031/ (дата обращения: 04.06.2020).

18. Демидова Е. Прикосновение ветра. URL: https:/www.kinopoisk .ru/film/840269/ (дата обращения: 04.06.2020).

19. Демидова Е. Феномен Этигэлова. Загадка Бурятского ламы.. URL: https:/www.kinopoisk.ru/film/1206349/ (дата обращения: 04.06.2020).

20. Доржиев Б. Убийца. URL: https://www.kinopoisk.ru/film/994605/ (дата обращения: 04.06.2020).

21. Дышенов Б. Улыбка Будды. URL: https://www.kinopoisk .ru/film/474385/ (дата обращения: 04.06.2020).

22. Дышенов Б. Наказ матери. URL: https://www.kinopoisk .ru/film/677736/ (дата обращения: 04.06.2020).

23. Дышенов Б. Отхончик. Первая любовь. URL: http://www.kinopo isk.ru/film/738344/ (дата обращения: 04.06.2020).

24. Дышенов Б. Степные игры. URL: https://www.kinopoisk. ru/film/861601/ (дата обращения: 04.06.2020). 
25. Дышенов Б. Шарнохой - жёлтый пёс. URL: https://www.kinopoisk. $\mathrm{ru} / \mathrm{film} / 1257543 /$ (дата обращения: 04.06.2020).

26. Егоров Ю. Случай в тайге. URL: http://www.kinopoisk .ru/level/1/film/43859/ (дата обращения: 04.06.2020).

27. Жалцанов Э. Эхо. URL: https://www.youtube.com/watch?v $=8 \mathrm{YOclX} 4 \mathrm{On} 4 \mathrm{w}$ (дата обращения: 04.06.2020).

28. Жалцанова Б. Ирония любви или с новым счастьем. URL: http://minkultrb.ru/news/prosmotr/browse/1/article/v-ulan-udeh-sostojalas-prezen tacija-filma-ironija-ljub/?tx_ttnews\%5BpS\%5D $=1296489600 \&$ tx_ttne ws\%5Bp L\%5D $=2419199 \&$ tx ttnews\%5Barc\%5D $=1 \&$ tx ttnews\%5BbackPid\%5D=319\&c Hash=a277d69209b6d6c0027ec26a81aeb15a (дата обращения: 04.06.2020).

29. Жалцанова Б. Холын харгыда. URL: https://www.youtube. com/watch?v=1ddGGE8r_6c (дата обращения: 04.06.2020) Изображение (движущееся, двухмерное): видео.

30. Жамбалов С. Первый нукер Чингисхана. URL: http://myhit.ru/film/1667/online (дата обращения: 04.06.2020).

31. Жамбалов С. Первый нукер Чингисхана (фильм). URL: https://www.youtube.com/watch?v=e3xe7rOkcBs (дата обращения: 04.06.2020) Изображение (движущееся, двухмерное): видео.

32. Инкижинов В. Расплата. URL: https://www.kinopoisk.ru/ film /395574/ (дата обращения: 04.06.2020).

33. Итыгилов А. Продаётся медвежья шкура. URL: https://www.kino poisk.ru/film/484373/ (дата обращения: 04.06.2020).

34. Козлов М. На Байкал. URL: https://www.kinopoisk.ru/film/636356/ (дата обращения: 04.06.2020).

35. Козлов М. На Байкал 2: На абордаж. URL: http://www.kinopoisk. ru/film/707288/ (дата обращения: 04.06.2020).

36. Козлов М. на Байкал: Поехали. URL: https://www.kinopoisk .ru/series/807500/ (дата обращения: 04.06.2020).

37. Козлов М. Стоп! Снято! На Байкал!. URL: https://www.kino poisk.ru/film/994654/ (дата обращения: 04.06.2020).

38. Кравцова М. Баир Уладаев представил проект нового фильма «Зуһалан». URL: https://tvcom-tv.ru/baira-uladaev-predstavil-proekt-novogofilma-«zuhalan».html (дата обращения: 04.06.2020).

39. Лапшин Я. Пора таёжного подснежника. URL: https://www.kino poisk.ru/film/568171/ (дата обращения: 04.06.2020).

40. Леонетти Д. Смертельная битва 2. URL: https://www.kinopoisk. ru/film/6842/ (дата обращения: 04.06.2020).

41. Лыгденов C. Золотые шахматы Будды. URL: https://www.kino poisk.ru/film/468237/ (дата обращения: 04.06.2020).

42. Лыгденов С. Булаг. URL: https://www.kinopoisk.ru/film/765113/ (дата обращения: 04.06.2020).

43. Лыгденов С. 321-я сибирская. URL: https://www.kinopoisk.ru /film/1047033/ (дата обращения: 04.06.2020).

44. Лыгденов С. «Булаг-2»: к новой жизни, к сердцам земляков // Буряад Унэн. URL: https://burunen.ru/site/news?id=31895 (дата обращения: 
04.06.2020).

45. Немчинова А. Байкальские каникулы. URL: https://www.kinopoisk .ru/film/933311/ (дата обращения: 04.06.2020).

46. Немчинова А. Байкальские каникулы 2.0. URL: https:/www.kino poisk.ru/film/1271107/ (дата обращения: 04.06.2020).

47. Никонов С. Гастролёры. URL: https://www.kinopoisk.ru/ film /893305/ (дата обращения: 04.06.2020).

48. Овчинников В. Смерти нет. URL: https:/www.kinopoisk.ru/ film/714466/ (дата обращения: 04.06.2020).

49. Овчинников В. Улан-Удэ, я люблю тебя!. URL: https:/www.kino poisk.ru/film/1197716/ (дата обращения: 04.06.2020).

50. Расходников М. Эластико. URL: https:/www.kinopoisk.ru/ film /980835/ (дата обращения: 04.06.2020).

51. Туприн Д. Шлагбаум. URL: http:/www.kinopoisk.ru/film/738344/ (дата обращения: 04.06.2020).

52. Уладаев Б. Живи. URL: https://www.youtube.com/watch?v =rmuf5MN8Tvc (дата обращения: 04.06.2020) Изображение (движущееся, двухмерное): видео.

53. Уладаев Б. Сэржэм. URL: https://www.youtube.com/ watch?v $=22 \mathrm{kmDc} 82 \mathrm{BT} 8$ (дата обращения: 04.06.2020) Изображение (движущееся, двухмерное): видео.

54. Уладаев Б. Хранители. URL: https://www.youtube.com/watch ?v=y82fKHtCUXs (дата обращения: 04.06.2020) Изображение (движущееся, двухмерное): видео.

55. Уладаев Б. На берегу мечты. URL: https://www.kinopoisk. ru/film/1184900/ (дата обращения: 04.06.2020).

56. Уладаев Б. Два капитана // kinopoisk. URL: https://www.kinopoisk .ru/film/1208998/ (дата обращения: 04.06.2020).

57. Фролов А. Песня табунщика. URL: https://www.kinopoisk.ru/ film/487459/ (дата обращения: 04.06.2020).

58. Фролов А. Аноним 03 (фильм). URL: https://www.kinopoisk. ru/film/839236/ (дата обращения: 04.06.2020).

59. Халзанов Б. Белая лошадь. URL: https://www.kinopoisk.ru/ film/861667/ (дата обращения: 04.06.2020).

60. Халзанов Б. Последний угон. URL: http://www.kinopoisk. ru/level/1 /film/391263/ (дата обращения: 04.06.2020).

61. Халзанов Б. Горький можжевельник. URL: https://www. kinopoisk .ru/film/44556/ (дата обращения: 04.06.2020).

62. Цыбиков Б. Дом на Луне. URL: https://vk.com/dom_na_lune (дата обращения: 04.06.2020).

63. Цыренов А. По совести. URL: https:/www.kinopoisk.ru/film/ 1306641/ (дата обращения: 04.06.2020).

64. Ширапов В. Прозрение. URL: https:/www.youtube. com/watch ?v=Yc-kzD_Fh_A (дата обращения: 04.06.2020) Изображение (движущееся, двухмерное): видео.

65. Яшников Ю. Похабовск. Обратная сторона Сибири. URL: 
https://www.kinopoisk.ru/film/772921/ (дата обращения: 04.06.2020).

66. Барас Халзанов. URL: https://www.kinopoisk.ru/name/307587/ (дата обращения: 04.06.2020).

67. Арья Дашиев. URL: https://ru.wikipedia.org/wiki/Дашиев, Арья Цыренович (дата обращения: 04.06.2020).

68. Александр Итыгилов. URL: https://www.kinopoisk.ru/name/290076/ (дата обращения: 04.06.2020).

69. Ирина Пантаева. URL: https://www.kinopoisk.ru/name/38613/ (дата обращения: 04.06.2020).

70. Баир Дышенов. URL: https://www.kinopoisk.ru/name/1845416/ (дата обращения: 04.06.2020).

71. Солбон Лыгденов. URL: https://www.kinopoisk.ru/name/1815893/ (дата обращения: 04.06.2020).

72. Баир Омоктуев // Wikipedia.org. URL: https://ru.wikipedia. org/wiki/Омоктуев, Баир Доржиевич (дата обращения: 04.06.2020).

73. Цырендулма Дондогой // Wikipedia.org. URL: https://ru.wikipedi a.org/wiki/Дондогой, Цырендулма Цыреновна (дата обращения: 04.06.2020).

74. Евгений Замалиев // kinopoisk. URL: https://www.kinopoisk. ru/name/2383895/ (дата обращения: 04.06.2020).

75. Артём Бурлов // kinopoisk. URL: https://www.kinopoisk.ru/name /2675188/ (дата обращения: 04.06.2020).

76. Потомок Чингисхана. URL: http://www.kinopoisk.ru/level/1/film /43178/ (дата обращения: 04.06.2020).

77. Первый нукер Чингисхана угодил в историю // Информ Полис. URL: https://www.infpol.ru/168466-pervyy-nuker-chingiskhana-ugodil-v-istoriyu (дата обращения: 04.06.2020).

78. В Улан-Удэ представили фильм «Ирония любви или с новым счастьем» // Baikal-Daily. URL: https://www.baikal-daily.ru/news/16/20537/ (дата обращения: 04.06.2020).

79. Аноним 03. URL: https://vk.com/anonim_o3 (дата обращения: 04.06.2020).

80. Бурятский сериал «Зачетная весна» выйдет на телеэкраны 13 июня // Информ Полис. URL: https://www.infpol.ru/100723-buryatskiy-serialzachetnaya-vesna-vyydet-na-teleekrany-13-iyunya/ (дата обращения: 04.06.2020).

81. Вышел тизер фильма «Байкальские каникулы-3» // Baikal-Daily. URL: https://www.baikal-daily.ru/news/16/375149/ (дата обращения: 04.06.2020).

82. Союз кинематографистов Республики Бурятия. URL: https://vk. com/kinoburyatia (дата обращения: 04.06.2020).

83. В Бурятии появился ещё один Союз кинематографистов // Байкал Медиа. URL: https://baikal-media.ru/news/culture/355232/ (дата обращения: 04.06.2020). 


\section{References}

1. Alfyorov V. Tanec orla [Dance of eagle]. URL: https://www.kinopoisk.ru/film/756976/ (04.06.2020). [In Russ.].

2. Alfyorov V. Zemlja schastlivogo uchenija [Land of happy study]. URL: https://www.kinopoisk.ru/film/891379/ (04.06.2020). [In Russ.].
3. Askhayev
$\mathrm{R}$.
Reshala
[Reshala].
URL: http://www.kinopoisk.ru/film/717355/ (04.06.2020). [In Russ.].
4. Askhayev
$\mathrm{R}$.
Reshala
2
[Reshala
2]. URL: https://www.kinopoisk.ru/film/892585/ (04.06.2020). [In Russ.].
5. Badmatsyrenov
$\mathrm{Zh}$.
Chajnik
[Teapot].
URL: https://www.kinopoisk.ru/film/580644/ (04.06.2020). [In Russ.].

6. Badmatsyrenov Zh. Ulan-Udenci [Residents of Ulan-Ude]. URL: https://www.kinopoisk.ru/film/677736/ (04.06.2020). [In Russ.].
7. Badmatsyrenov
$\mathrm{Zh}$.
Buuzy
[Buuzas].
URL: http://www.kinopoisk.ru/film/733142/ (04.06.2020). [In Russ.].
8. Badmatsyrenov
J.
Chajnik
[Teapot
2]. URL: https://www.kinopoisk.ru/film/767124/ (04.06.2020). [In Russ.].

9. Badmatsyrenov J. Reshala. Nulevyje [Reshala. Zero years]. URL: https://www.kinopoisk.ru/film/1280515/ (04.06.2020). [In Russ.].

10. Basov V. Zolotoj dom [The Golden House]. URL: https://www.kinopoisk.ru/film/751812/ (04.06.2020). [In Russ.].

11. Batorov A. Ulan-Udenskaja istorija [Ulan-Ude story]. URL: https://www.kinopoisk.ru/film/802924/ (04.06.2020). [In Russ.].

12. Botoev $\mathrm{Yu}$. Tajna zaveshchanija [Secret of will]. URL: http://www.kinopoisk.ru/film/710101/ (04.06.2020). [In Russ.].
13. Botoev
$\mathrm{Yu}$.
Golovar
[Golovar].
URL: https://www.kinopoisk.ru/film/1111862/ (04.06.2020). [In Russ.].

14. Botoev Yu. V Burjatii zavershili c"'jemki fil'ma «Zoloto imperii» [The shooting of the film "The empire's gold" has been over] // Vostok Teleinform [Vostok teleinform]. URL: https://vtinform.com/news/148/148402/ (04.06.2020). [In Russ.].

15. Dashiev A. Tri solnca [The three suns]. URL: https://www.kinopoisk.ru/film/754813/ (04.06.2020). [In Russ.].

16. Dashiev A. Krik tishiny [Scream of silence]. URL: http://www.kinopoisk.ru/level/1/film/44982/ (04.06.2020). [In Russ.].

17. Dashiev A. Utro obrechennogo priiska [Morning of the doomed mine]. URL: http://www.kinopoisk.ru/level/1/film/153031/ (04.06.2020). [In Russ.].

18. Demidova Ye. Prikosnovenije vetra [The wind touch]. URL: https://www.kinopoisk.ru/film/840269/ (04.06.2020). [In Russ.].

19. Demidova Ye. Fenomen Etigelova. Zagadka Burjatskogo lamy [Etigelov's phenomenon. The riddle of the Buryat lama. URL: https://www.kinopoisk.ru/film/1206349/ (04.06.2020). [In Russ.].

20. Dorzhiev B. Ubijca [The murderer]. URL: https://www.kinopoisk.ru/film/994605/ (04.06.2020). [In Russ.].

21. Dyshenov B. Ulybka Buddy [Buddha's smile]. URL: https://www.kinopoisk.ru/film/474385/ (04.06.2020). [In Russ.]. 
22. Dyshenov B. Nakaz materi [The mother's order]. URL: https://www.kinopoisk.ru/film/677736/ (04.06.2020). [In Russ.].

23. Dyshenov B. Otkhonchik. Pervaja lubov' [Otkhonchik. The first love]. URL: http://www.kinopoisk.ru/film/738344/ (04.06.2020). [In Russ.].

24. Dyshenov B. Stepnije igry [Steppe games]. URL: https://www.kinopoisk.ru/film/861601/ (04.06.2020). [In Russ.].

25. Dyshenov B. Sharnokhoj - zhjeltyj pes [Sharnokhoy - a yellow dog]. URL: https://www.kinopoisk.ru/film/1257543/ (04.06.2020). [In Russ.].

26. Yegorov $\mathrm{Yu}$. Sluchaj $\mathrm{v}$ taige [Case in the taiga]. URL: http://www.kinopoisk.ru/level/1/film/43859/ (04.06.2020). [In Russ.].

27. Zhaltsanov E. Ekho [Echo]. URL: https://www.youtube.com/watch? $\mathrm{v}=8$ YOclX4On4w (04.06.2020). [In Russ.]

28. Zhaltsanova B. Ironija lubvi ili s novym schastjem [Irony of love or with new happiness]. URL: http://minkultrb.ru/news/prosmotr/browse/1/article/vulan-udeh-sostojalas-prezentacija-filma-ironija-ljub/?tx ttnews $\% 5 \mathrm{BpS} \% 5 \mathrm{D}=129$ 6489600\&tx ttnews\% $\% 5 \mathrm{BpL} \% 5 \mathrm{t}=\mathrm{nt} 5 \mathrm{nt} 5 \mathrm{nt} 5 \mathrm{nt5}$ _tnn_sn5_tn_5nn5s_tn_5nn5s_tn_5 $\%$ 5Barc\% 5D $=1$ \& tx ttnews\% 5BbackPid\% 5D = 319 \& $\mathrm{cHash}^{=}$ a277d69209b6d6c0027ec26a81aeb15a (04.06.2020). [In Russ.].

29. Zhaltsanova

В. Холын

харгыда.

URL: https://www.youtube.com/watch?v=1ddGGE8r_6c (04.06.2020). [In Buryat].

30. Zhambalov S. Pervyj nuker Chingiskhana [The first nuker of Genghis Khan]. URL: http://my-hit.ru/film/1667/online (04.06.2020). [In Russ.].

31. Zhambalov S. Pervyj nuker Chingiskhana (film) [The first nuker of Genghis Khan (film)]. URL: https://www.youtube.com/watch? $\mathrm{v}=\mathrm{e} 3 \mathrm{xe} 7 \mathrm{rOkcBs}$ (04.06.2020). [In Buryat].

32. Inkizhinov V. Rasplata [Payback]. URL: https://www.kinopoisk.ru/film/395574/ (04.06.2020). [In Russ.].

33. Itygilov A. Prodaetsja medvezhja shkura [A bear skin is sold]. URL: https://www.kinopoisk.ru/film/484373/ (04.06.2020). [In Russ.].

34. Kozlov M. Na Baikal [To the Baikal]. URL: https://www.kinopoisk.ru/film/636356/ (04.06.2020). [In Russ.].

35. Kozlov M. Na Baikal 2: Na abordazh [To the Baikal 2: Boarding]. URL: http://www.kinopoisk.ru/film/707288/ (04.06.2020). [In Russ.].

36. Kozlov M. Na Baikal: Poekhali [To the Baikal: Let's go]. URL: https://www.kinopoisk.ru/series/807500/ (04.06.2020). [In Russ.].

37. Kozlov M. Stop! Snjato! Na Baikal [Stop! Has been shot! To the Baikal!]. URL: https://www.kinopoisk.ru/film/994654/ (04.06.2020). [In Russ.].

38. Kravtsova M. Bair Uladaev predstavil projekt novogo fil'ma «Зуһалан» [Bair Uladaev presented the project of the new film "Zuhalan"]. URL: https://tvcom-tv.ru/baira-uladaev-predstavil-proekt-novogo-filma-«zuhalan».html (04.06.2020). [In Russ.].

39. Lapshin Ya. Pora taezhnogo podsnezhnika [It is time for taiga snowdrop]. URL: https://www.kinopoisk.ru/film/568171/ (04.06.2020). [In Russ.].

40. Leonetti D. Smertel'naja bitva 2 [Mortal Kombat 2]. URL: https://www.kinopoisk.ru/film/6842/ (04.06.2020). [In Russ.]

41. Lygdenov S. Zolotyje shakhmaty Buddy [Buddha's golden chess]. 
URL: https://www.kinopoisk.ru/film/468237/ (04.06.2020). [In Russ.].
42. Lygdenov
S. Bulag
[Bulag].

URL:

https://www.kinopoisk.ru/film/765113/ ((04.06.2020). [In Russ.].

43. Lygdenov S. 321-ja sibirskaja [The $321^{\text {st }}$ Siberian]. URL: https://www.kinopoisk.ru/film/1047033/ (04.06.2020).

44. Lygdenov S. "Bulag-2": k novoj zhizni, k serdcam zemljakov ["Bulag2": to new life, to the hearts of the countrymen // Буряад Унэн. URL: https://burunen.ru/site/news?id=31895 (04.06.2020). [In Russ.].

45. Nemchinova A. Baikal'skije kanikuly [The Baikal holidays]. URL: https://www.kinopoisk.ru/film/933311/ (04.06.2020).

46. Nemchinova A. Baikal'skije kanikuly 2.0 [The Baikal holidays 2.0]. URL: https://www.kinopoisk.ru/film/1271107/ (04.06.2020). [In Russ.].

47. Nikonov S. Gastrolery [Guest performers]. URL: https://www.kinopoisk.ru/film/893305/ (04.06.2020). [In Russ.].

48. Ovchinnikov V. Smerti net [There is no death]. URL: https://www.kinopoisk.ru/film/714466/ (04.06.2020). [In Russ.].

49. Ovchinnikov V. Ulan-Ude, ja ljublju tebja [Ulan-Ude, I love you]. URL: https://www.kinopoisk.ru/film/1197716/ (04.06.2020). [In Russ.].

50. Raskhodnikov M. Elastiko [Elastico]. URL: https://www.kinopoisk.ru/film/980835/ (04.06.2020). [In Russ.].

51. Tuprin D. Shlagbaum [The barrier]. URL: http://www.kinopoisk.ru/film/738344/ (04.06.2020). [In Russ.].
52. Uladaev
B.
Zhivi
[Live].
URL:

https://www.youtube.com/watch?v=rmuf5MN8Tvc (04.06.2020) [In Russ.].

53. Uladaev B. Сэржэм [Electronic source]. URL: https://www.youtube.com/watch?v=22kmDc82BT8 (04.06.2020). [In Buryat].
54. Uladayev
B.
Khraniteli
[Keepers].
URL:

https://www.youtube.com/watch? $v=y 82 f K H t C U X s ~(04.06 .2020)$. [In Russ.].

55. Uladaev B. Na beregu mechty [On the shore of a dream]. URL: https://www.kinopoisk.ru/film/1184900/ (04.06.2020). [In Russ.].

56. Uladaev B. Dva kapitana [Two captains] // Kinopoisk [Film search]. URL: https://www.kinopoisk.ru/film/1208998/ (04.06.2020). [In Russ.].

57. Frolov A. Pesnja tabunshika [The herder's song]. URL: https://www.kinopoisk.ru/film/487459/ (04.06.2020). [In Russ.].

58. Frolov A. Anonym 03 (film) [Anonymous 03 (film)]. URL: https://www.kinopoisk.ru/film/839236/ (04.06.2020). [In Russ.].

59. Khalzanov B. Belaja loshad' [The white horse]. URL: https://www.kinopoisk.ru/film/861667/ (04.06.2020). [In Russ.].

60. Khalzanov B. Poslednij ugon [The last carjacking]. URL: http://www.kinopoisk.ru/level/1/film/391263/ (04.06.2020). [In Russ.].

61. Khalzanov B. Gor'kij mozhevel'nik [Bitter juniper]. URL: https://www.kinopoisk.ru/film/44556/ (04.06.2020). [In Russ.].

62. Tsybikov B. Dom na lune [The house on the moon]. URL: https://vk.com/dom_na_lune (04.06.2020) [In Russ.].

63. Tsyrenov A. Po sovesti [On the conscience]. URL: https://www.kinopoisk.ru/film/1306641/ (04.06.2020). [In Russ.]. 
64. Shirapov

V. Prozrenije

[Insight].

URL:

https://www.youtube.com/watch?v=Yc-kzD_Fh_A (04.06.2020). [In Russ.].

65. Yashnikov Yu. Pokhabovsk. Obratnaja storona Sibiri [Pokhabovsk. The reverse side of Siberia]. URL: https://www.kinopoisk.ru/film/772921/ (04/06/2020). [In Russ.].

66. Baras Khalzanov [Baras Khalzanov]. URL: https://www.kinopoisk.ru/name/307587/ (04.06.2020). [In Russ.].

67. Arja Dashiev [Arya Dashiev]. URL: https://ru.wikipedia.org/wiki/ Дашиев, Арья Цыренович (04.06.2020). [In Russ.].

68. Aleksandr Itygilov [Alexander Itygilov]. URL: https://www.kinopoisk.ru/name/290076/ (04.06.2020). [In Russ.].

69. Irina Pantajeva [Irina Pantaeva]. URL: https://www.kinopoisk.ru/name/38613/ (04.06.2020). [In Russ.].

70. Bair Dyshenov [Bair Dyshenov]. URL:

https://www.kinopoisk.ru/name/1845416/ (04.06.2020). [In Russ.].

71. Solbon Lygdenov [Solbon Lygdenov]. URL: https://www.kinopoisk.ru/name/1815893/ (04.06.2020). [In Russ

72. Bair Omoktuev [Bair Omoktuev] // Wikipedia.org [Wikipedia.org]. URL: https://ru.wikipedia.org/wiki/ Омоктуев, Баир Доржиевич (04.06.2020). [In Russ.].

73. Tsyrendulma Dondogoj [Tsyrendulma Dondogoy] // Wikipedia.org. [Wikipedia.org]. URL: https://ru.wikipedia.org /wiki/Дондогой, Цырендулма Цыреновна (04.06.2020). [In Russ.].

74. Evgenij Zamalijev [Evgeny Zamaliev] // Kinopoisk [Film search]. URL: https://www.kinopoisk.ru/name/2383895/ (04.06.2020). [In Russ.].

75. Artjom Burlov [Artem Burlov] // Kinopoisk [Film search]. URL: https://www.kinopoisk.ru/name/2675188/ (04.06.2020). [In Russ.].

76. Potomok Chingiskhana [Genghis Khan's descendant]. URL: http://www.kinopoisk.ru/level/1/film/43178/ (04.06.2020). [In Russ.].

77. Pervyj nuker Chingiskhana ugodil $\mathrm{v}$ istoriju [The first nuker of Chinggis Khan made a story] // Inform Polis [Inform Polis]. URL: https://www.infpol.ru/168466-pervyy-nuker-chingiskhana-ugodil-v-istoriyu/ (04.06.2020). [In Russ.].

78. V Ulan-Ude predstavili film «Ironija lubvi ili s novym schastjem [The film «The Irony of Love or With New Happiness» was presented in Ulan-Ude] // Baikal-Dajli [Baikal-Daily]. URL: https://www.baikal-daily.ru/news/16/20537/ (04.06.2020). [In Russ.].

79. Anonim 03 [Anonymous 03]. URL: https://vk.com/anonim_o3 (04.06.2020). [In Russ.].

80. Burjatskij serial «Zachjetnaja vesna vyjdet na teleekrany 13 ijunja [The Buryat serial "Credible spring" will be released on TV on June 13] // Inform Polis [Inform Polis]. URL: https://www.infpol.ru/100723-buryatskiy-serialzachetnaya-vesna-vyydet-na-teleekrany-13-iyunya/ (04.06.2020). [In Russ.].

81. Vyshel tizer filma «Baikal'skije kanikuly-3 [The film teaser "Baikal Holiday-3" has come out] // Baikal-Daily [Electronic source]. URL: https://www.baikal-daily.ru/news/16/375149/ (04.06.2020). [In Russ.]. 
82. Sojuz kinematografistov Respubliki Burjatija [The Union of cinematographers of the Republic of Buryatia]. URL: https://vk.com/kinoburyatia (04.06.2020). [In Russ.].

83. B Burjatii pojavilsja eshchje odin Sojuz kinematografistov [Another Union of cinematographers appeared in Buryatia] // Baikal-Medija [BaikalMedia]. URL: https://baikal-media.ru/news/culture/355232/ (04.06.2020). [In Russ.]. 


\section{Волобуева Н. В.}

Volobueva $N$. $V$.

\section{КРАТКИЙ СТРУКТУРНО-ИСПОЛНИТЕЛЬСКИЙ АНАЛИЗ ПРОИЗВЕДЕНИЙ ДЛЯ ЧАНЗЫ КОМПОЗИТОРА ДАРЬИ КОРКИНОЙ}

\section{A BRIEF STRUCTURAL PERFORMANCE ANALYSIS OF THE WORKS FOR CHANZA OF THE COMPOSER DARYA KORKINA}

В данной статье осуществлена попытка структурноисполнительского анализа произведений для чанзы композитора Д.Л. Коркиной. На основе определения музыкально-выразительных средств и интонационного языка композитора автор делает заключение по поводу стиля и актуальности данного произведения в ряду аналогичных.

The article attempts to give the structural performance analysis of the works for chanza of the composer D.L. Korkina. On the basis of the composer's musical and expressive means and intonation language the author makes a conclusion about the style and actual character of the work in comparison with similar ones.

Ключевые слова: музыка, исполнитель, композиторский стиль, чанза, произведения, содержание, исполнительские приемы.

Keywords: music, performer, composer's style, cnansa, works, content, performing techniques.

Чанза - бурятский струнный плекторный инструмент монгольского происхождения (шанза, шудрага). Родственные инструменты имеются в Китае (сан хсьен), Японии (сямисен). В конце 1930-х годов шанза появилась на территории Бурят-Монгольской Автономной Советской Социалистической Республики, в период формирования первого в истории оркестра бурятских народных инструментов [1].

Дарьей Коркиной созданы 4 произведения для чанзы с фортепиано:

1. сюита «Национальные узоры». Исполняются только две части «Лирическая пьеса» и «Рондо»;

2. концертная пьеса для чанзы и фортепиано;

3. концертная пьеса «Танцующее пламя»;

4. «Поэма» по мотивам бурятской легенды об Эхэ бурхан.

Каждое из них достойно внимания со стороны исполнителя. Так, сюита «Национальные узоры» была создана в 2006 году, когда её автор была студенткой III-го курса Восточно-Сибирской государственной академии культуры и искусств. Это первое произведение автора, написанное с использованием средств музыкальной выразительности бурятского фольклора с мелодико-гармонической пентатонной основой. 
Поскольку, основу сюиты, как циклического произведения, представляет образный контраст, так и «Национальные узоры» состоят из двух разнохарактерных пьес. Обе насыщены ритмическими фигурами, сменами темпа и разнообразными штрихами.

Начальная «Лирическая пьеса» обладает спокойным, безмятежным характером с напевной мелодией, вызывающей ассоциации с картинами природы. Она укладывается в рамки простой 3-хчастной формы.

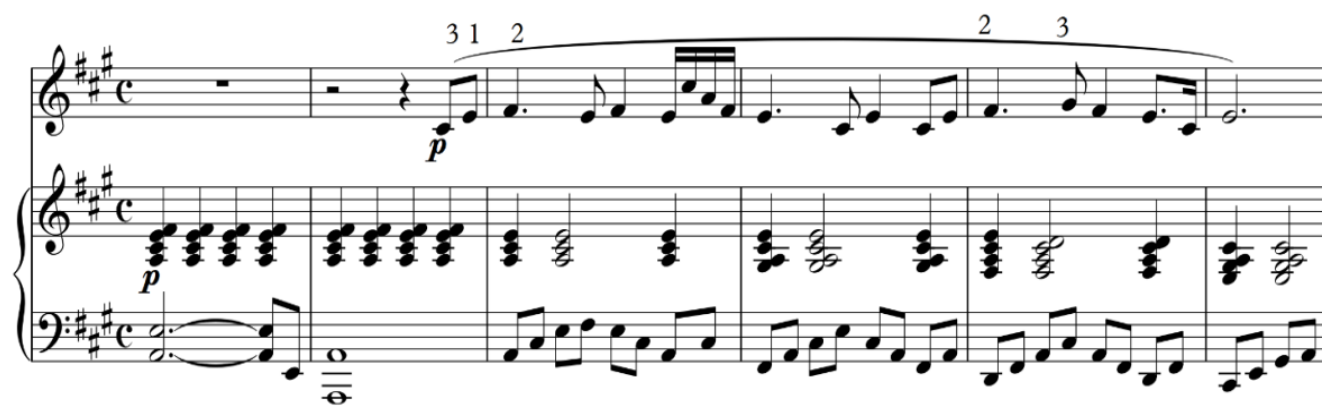

Вторая пьеса - «Рондо» лёгкого игривого характера, в которой рефрен представляет собой мужскую энергичную пляску, эпизоды - плавный, но упругий женский танец, сообразно этому происходит смена размера и темпа, придающая внутреннюю гибкость и пластичность частям.

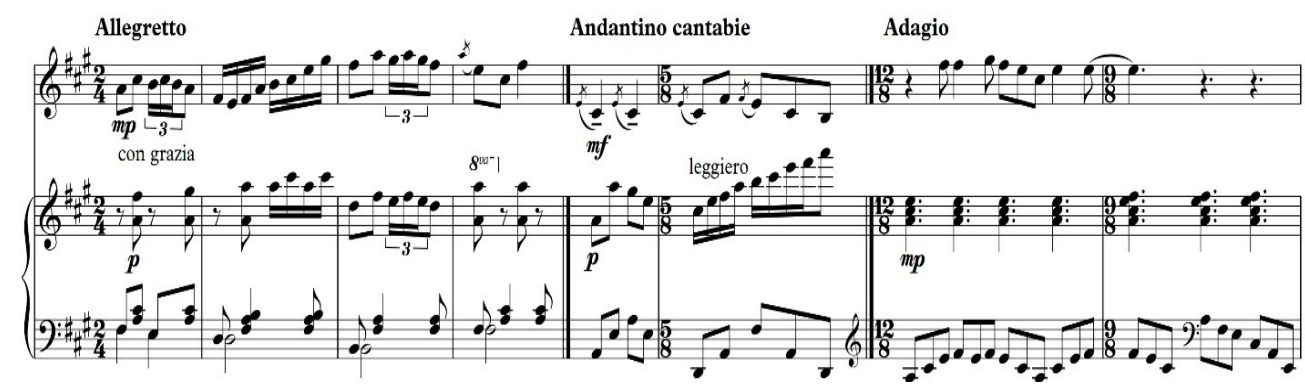

Здесь очень важно соблюдение ансамбля между партиями, которые являются равноправными. Это вытекает из того, что смысловое содержание данного произведения равномерно распределено между фортепиано и чанзой.

Сюита выделяется среди других произведений наличием исполнительской редакции: аппликатура и штрихи указаны со знанием технических возможностей инструмента, что делает данное произведение доступным и для контингента ДМШ и ДШИ.

«В современных оригинальных произведениях используется весь арсенал технических приемов и средств: виртуозных, колористических и динамических. Используя их, можно добиться богатой тембровой окраски звучания, «одухотворить» звук, сделать его выразительным, певучим» [1]. 
Во всех своих произведениях для чанзы Дарья Леонидовна тщательно подбирает все исполнительские приёмы, раскрывая музыкальный образ, что особенно выделяется в следующих произведениях.

В следующем 2007 году Дарья Коркина создает «Концертную пьесу для чанзы и фортепиано», выполняя заказ чанзистки Анны Субановой. Как и предыдущая, эта пьеса написана на материале бурятского фольклора с внедрением технически сложных чисто инструментальных приёмов: флажолетов, трелей и glissando.

Форма произведения - сложная трехчастная: крайние разделы в быстром темпе представляют собой простую трехчастную форму, а середина эпизод элегического характера. Основная тема виртуозно моторного характера в партии чанзы состоит из безостановочного потока

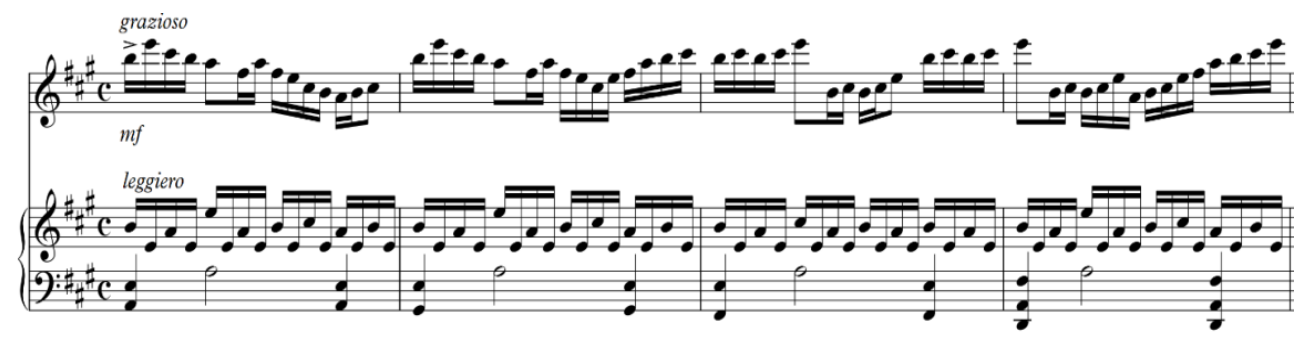

шестнадцатых и развивается на протяжении всего раздела. Особенно мягко и лирично звучит середина - элегия, построенная на мотивах лирического фольклора. Партия сопровождения у фортепиано ритмически насыщенная, она как бы обволакивает мелодию, что создает эффект звуковой «подушки», на фоне которой естественный приглушенный тембр чанзы-solo раскрывается особенными красками, не свойственных, казалось бы, ограниченным возможностям чанзы.

Подобно сюите «Национальные узоры», в пьесе огромная смысловая и мелодическая нагрузка ложится не только на чанзу, но и фортепиано.

Однако, Концертная пьеса в отличие от предыдущего произведения, требует от исполнителя самостоятельного выбора аппликатуры, расстановки приемов игры и штрихов, согласно имеющимся обозначениям в нотах. Поэтому данное произведение предназначено, по нашему мнению, лишь для более продвинутых исполнителей.

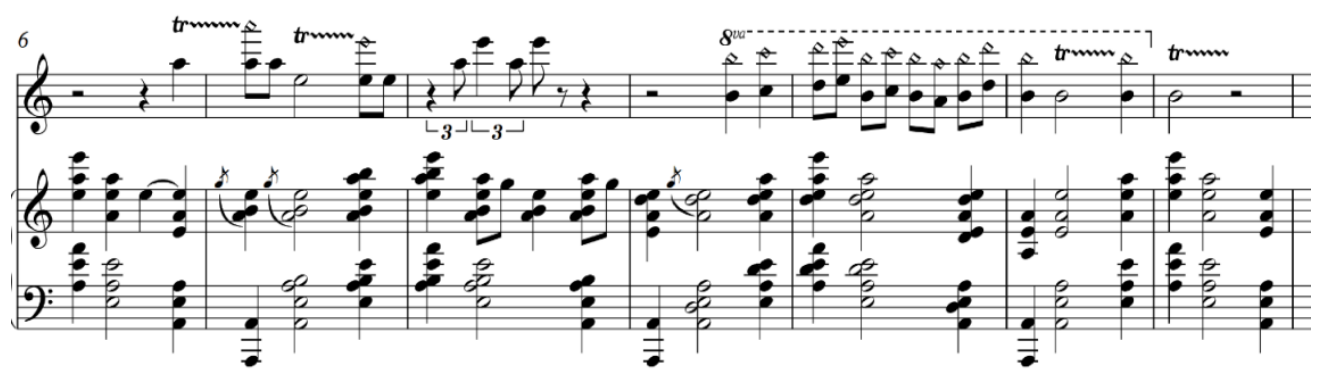


На этом различия не заканчиваются. Если тема крайних частей для взрослого исполнителя не несёт трудностей, то средняя часть требует повышенного слухового контроля и умения не только владеть приёмами игры, но и тонкостями перехода одного приёма на другой. Как в данном примере - исполнитель должен сыграть трель, подводя её окончание во флажолет.

Таким образом, можно сказать, что Концертная пьеса доступна для исполнения студентами ССУЗов и ВУЗов, однако по причине владения исполнительской техники и виртуозности сложна для учащихся ДШИ И ДМШ.

Следующие две концертные пьесы - «Танцующее пламя» и «Поэма» - наиболее яркие и показательные в творчестве Дарьи Коркиной принесли композитору звание Дипломанта международного конкурса композиторского искусства «Композитор XXI века». Первым их исполнителем стала Анна Субанова. Она же и делала исполнительскую редакцию произведений. Аудиозапись пьес можно найти на сайте $[3,6]$.

«Концертная пьеса» является заказом, а вот «Танцующее пламя» и «Поэма» являются произведениями, идея которых появилась у меня самой», - говорит Д. Коркина. «Надо сказать, что все эти сочинения были созданы согласно исполнительским возможностям Анны Субановой. После появилось достаточно сложное технически произведение «Танцующее пламя», отвечающее возможностям Анны. Узнав, что в 2014 г. в Калуге пройдет конкурс композиторов и исполнителей, я сделала предложение написать для неё современное концертное произведение на основе бурятской музыки. И на данный момент Анна Борисовна является постоянной и, можно сказать, единственной исполнительницей этих пьес» [5].

Данные произведения раскрывают творчество Дарьи Коркиной, вбирая в себя наиболее излюбленные приёмы композиторского стиля. Для них характерны современные ритмы, часто встречающиеся в электронной музыке, бурятский музыкальный фольклор как средство музыкальной выразительности, звукоизобразительность и равенство партий.

Большинство исполнителей, включая эти произведения в репертуар, сталкивается со сложностями в их интерпретации. Но при вдумчивом прослушивании аудиозаписей, имеющихся в свободном интернет-доступе, вопросы трактовки прекратили бы своё существование. «Решение проблем, связанных с трактовкой и прочтением пьес, вероятно, лежит в прослушивании уже имеющихся записей произведений, а также в проведении творческих встреч и репетиций с автором», - говорит Д. Коркина[4].

«Большое внимание нужно уделять интонации, качеству звука и тембровой окраске. Звук должен быть выразительным, осмысленным, соответствовать музыкально-художественному образу. Исполнение должно находиться под постоянным слуховым контролем» [2].

Однако, несмотря на это, в произведениях присутствует немало технических и звукоизобразительных сложностей. Так, «Танцующее пламя» написано в сонатной форме с усеченной репризой.

Особенная сложность кроется в ансамбле фортепиано и чанзы при том, что композиторский стиль Дарьи Коркиной отличает равноправность 
партий. Партия фортепиано изобилует массивной аккордовой фактурой и сложными синкопированными ритмами, природа которых исходит из популярной современной и электронной музыки. На её фоне звучит мелодически насыщенная партия чанзы, но более простая в ритмическом отношении.

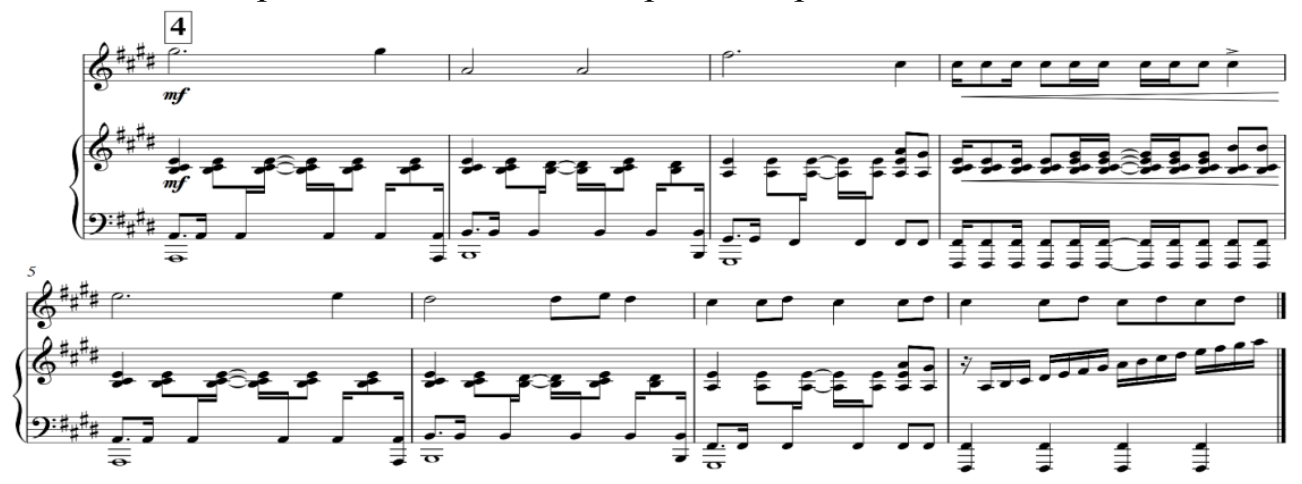

Очень важно не только сыграть вместе, но и добиться звукового баланса между партиями, так как плотная фактура фортепиано может заглушить чанзу.

Сложность произведения заключена также в двух новаторски исполненных каденциях, притом каденции чанзы вкраплена в фортепианную каденцию. Здесь особая роль ансамбля состоит в том, что в потоке фортепианных нисходящих и восходящих пассажей чанзистке почти невозможно определить нужную долю, как для вступления, так и для исполнения. В данном вопросе существует только два способа решения: консультация с композитором, или попытка договориться с концертмейстером.

Аналогичные сложности встретятся и в произведении «Поэма», созданного по мотивам космогонической легенды о божестве - Матери Жизни (Эхэ бурхан).
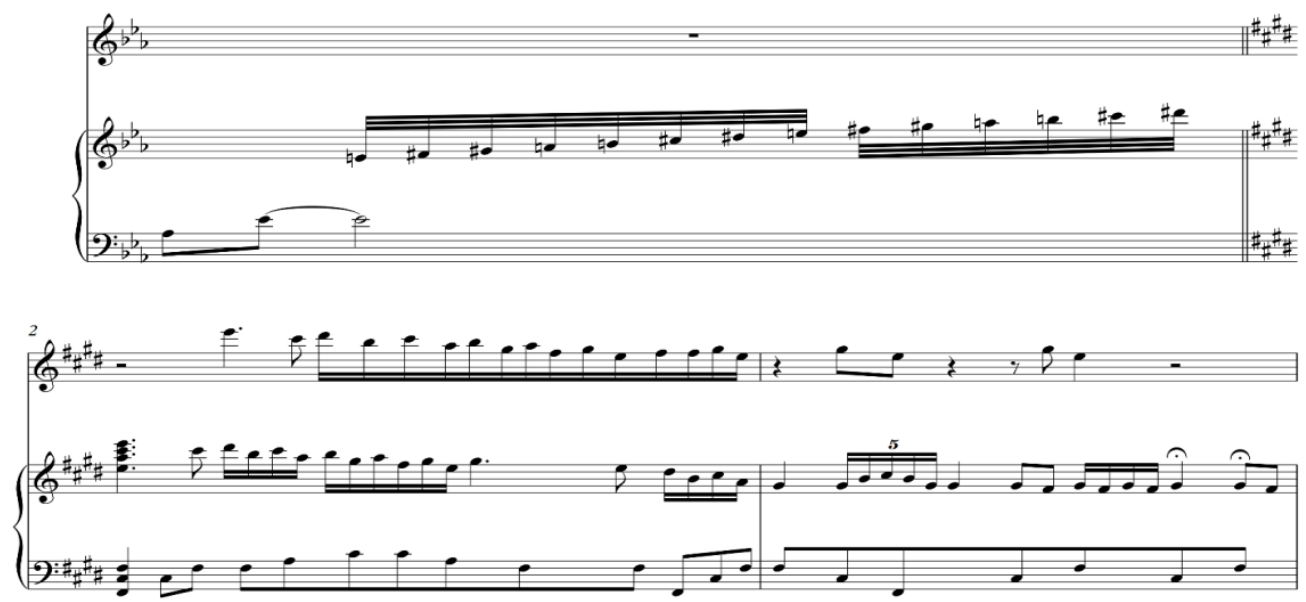

Для понимания произведения следует обратиться к эпическим источникам, согласно которым широко распространена следующая версия. 
«Вначале был хаос, в котором во мраке бродила Великая Мать - богиня Эхэ бурхан. Решила она разъединить небо и землю, сделала дикую утку, та нырнула в воду и принесла в клюве грязь. Из этой грязи Эхэ бурхан слепила землю-матушку Ульгенъ, затем сотворила на ней растения и животных. Эхэ бурхан родила от Солнца дочь - добрую Манзан Гурмэ, от которой позже родились все западные божества. Вторую дочь - злую Маяс Хара Эхэ бурхан родила от Месяца, от которой пошли все восточные небожители. Первые люди появились на земле тоже благодаря Эхэ бурхан. На стороне солнечного заката она создала женское начало, на стороне восхода - мужское. Они встретились, соединились, и родились первые мужчина и женщина - Паханг и Туя» $[7 ; 8]$.

Форма произведения - свободные вариации на бурятскую тему. В Поэме присутствует только одна тема - образ самой Эхэ бурхан, а последующие вариации изображают её детей и её творения. Наличие лишь единственной темы указывает на связь Эхэ бурхан и плодов её творений, по аналогии пуповинной связи - мать и дитя.

Способов варьирования здесь встречается много - гармонические, ритмические, темповые, использование различных приемов игры, в том числе и шумовых, а также пение.
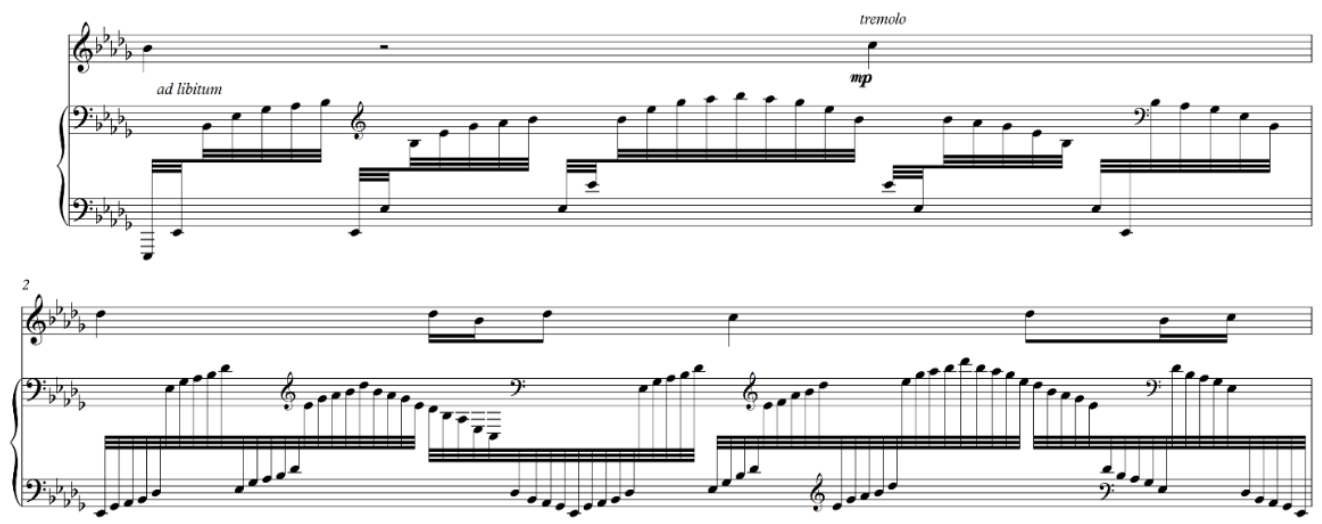

Как и в предыдущих произведениях Дарьи Коркиной, в Поэме прослеживаются черты композиторского стиля через излюбленные приемы: бурятское фольклорное цитирование, современные синкопированные ритмы, насыщенная фактура, изобретательная звукоизобразительность, равенство партий.

Особенность данного произведения заключена в редко используемых приёмах игры - игра по прижатым струнам, пение с гармоническим сопровождением на чанзе, флажолеты, глиссандо, хлопки.

Произведения кантиленного характера отличаются отношением исполнителя к звуку. Партия чанзы усложнена в Поэме аккордовой фактурой, исполнять которую необходимо приемом tremolo. Такая фактура встречается эпизодически, т.е. в момент кульминации. Здесь эта фактура является основополагающей. 
Но большую сложность для чанзиста представляет его вокальная партия, наполненная мордентами, форшлагами и другими фиоритурами. Подобный прием был использован лишь однажды - в произведении Виктора Усовича «Прохладная Селенга». Её исполнителем тоже была А. Субанова. Этот приём включения вокальной партии в инструментальное произведение можно признать новаторским, ибо для классической исполнительской практики он не характерен.

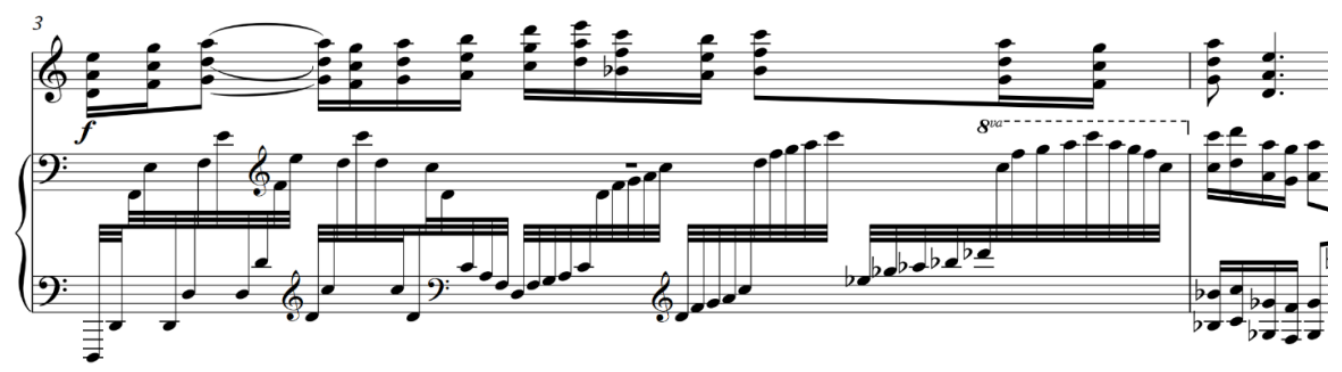

Здесь, как и в предыдущих произведениях важна роль ансамбля фортепиано и чанзы, определяемая насыщенной фактурой как партии чанзы, так и фортепиано.

Произведения «Танцующее пламя» и «Поэма» рассчитаны на более зрелых концертных исполнителей, преподавателей, и студентов ВУЗов. С учётом того, что последние произведения создавалось на возможности Анны Субановой и автора за роялем.

Для того, чтобы понять степень актуальности произведений для чанзы Дарьи Коркиной, необходимо определить требования для современных исполнителей.

Первое - высокий исполнительский уровень произведений для чанзы. Сегодня на профессиональной сцене встречаются юные музыканты, демонстрирующие хорошую техническую базу. В противовес тому, что произведения Д. Коркиной требуют владения мелкой техникой - своего рода perpetummobile - «вечное движение» (моторная игра шестнадцатых в быстром темпе), так и различными приемами игры (флажолеты, glissando).

Излюбленным средством музыкальной выразительности Д. Коркиной является использование бурятского фольклора, что важно, чанза является предметным воплощением духовно-материальной национальной культуры, пригодным для сохранения и популяризации национальной культуры.

Традиционный фольклор соединён в творчестве Д. Коркиной с приметами современного музыкального языка и ритмами электронной музыки, приобретая новый, освежающий колорит. Потому её произведения для чанзы вполне актуальны для сегодняшних исполнителей и слушателей и отвечают их желаниям и чаяниям. К сожалению, таких почитателей творчества Д. Коркиной и любителей традиционной инструментальной музыки ничтожно мало. Потому эти произведения редко исполняются, как и мало аудио- и видеозаписей, которые помогли бы исполнителю их постичь в деталях. 
Надеюсь, что данная статья поможет юным исполнителям и преподавателям в трактовке и исполнении произведений для чанзы Дарьи Коркиной.

\section{Примечания}

1. Чанза: Школа мастерства : учеб. пособие : в 3 ч. / Федерал. агентство по культуре и кинематографии РФ, Вост.-Сиб. гос. акад. культуры и искусств, Рос. акад. музыки им. Гнесиных [и др.] ; ред. и сост. В. В. Китов. Улан-Удэ : Информполис, 2007. 3 ч.

2. Субанова А. Б. Исполнительский анализ концерта для чанзы с симфоническим оркестром В. А. Усовича : учеб.-метод. пособие / Вост.-Сиб. гос. акад. культуры и искусств, Ин-т музыки, Каф. нар. инструментов. УланУдэ : Изд.-полигр. комплекс ВСГАКИ, 2014. 40 с.

3. Пасхальный бенефис // ATB online : сетевое издание. URL: http://tvatv.ru/news/6/295070/ (дата обращения: 22.04.2020).

4. Радио "Маяк" Улан-Удэ. «КОФЕ ТАЙМ». Дарья Коркина. Композитор. URL: https://www.youtube.com/watch? $=\mathrm{aOZ}$ zfrXW3w (дата обращения: 22.04.2020).

5. II конкурс "Композитор XXI века". I тур. Дуэт Анны Субановой и Дарьи Коркиной. URL: https://www.youtube.com/watch?v=aPmuzg4uSnQ (дата обращения: 25.04.2020).

6. Буряты, мифы, легенды и предания : отрывок из научной работы // Иркипедия.ru : энциклопедия и новости Приангарья. URL: http://irkipedia.ru/content/buryaty_mify_legendy_i_predaniya (дата обращения: 17.03.2020).

7. Коркина Дарья Леонидовна // Союз Композиторов России : Bсероссийская общественная организация.

URL: https://unioncomposers.ru/composer/view/?id=272 (дата обращения 28.03.2020).

8. Международный конкурс композиторов имени Юрия Фалика 02.07.2012 // РГМЦ. Российский государственный музыкальный телерадиоцентр. URL: http://www.muzcentrum.ru/news/2012/07/9465-mezhdunarodnyjkonkurs-kompozitorov-imeni-yuriya-falika (дата обращения: 28.03.2020).

\section{References}

1. Chanza: Shkola masterstva : ucheb. posobije : v 3 ch. [Chanza. School of mastery : manual : in 3 parts / Federal agency for culture and cinematography of the Russian Federation, East-Sib. state acad. of culture and arts, Russian academy of music named after Gnesinykh [et.al.] ; ed. and comp. by V. V. Kitov. Ulan-Ude, 2007. Part 3. [In Russ.].

2. Subanova A. B. Ispolnitel'skij analiz koncerta dlja chanzy s symphonicheskim orkestrom V. A. Usovicha : ucheb.-metod. posobije [The analysis of performing of the concert for chanza with the symphony orchestra of $\mathrm{V}$. A. Usovich : manual] / East-Siberian state acad. of culture and arts, Institute of music, Depart. of folk instruments. Ulan-Ude, 2014. 40 p. [In Russ.]. 
3. Paskhal'nyj benefis [Easter benefit] // ATB online : setevoje izdanije. [ATB online : network edition]. URL: http://tvatv.ru/news/6/295070/ (22.04.2020). [In Russ.].

4. Radio "Мајак" Ulan-Ude. «KOFE TAJM». Darja Korkina. Kompositor [Radio "Мауак" Ulan-Ude. «COFFEE TIME». Darya Korkina. Composer]. URL: https://www.youtube.com/watch?v=aOZ4zfrXW3w (22.04.2020). [In Russ.].

5. II konkurs "Koмpositor XXI veka". I tur. Duet Anny Subanovoj i Darji Korkinoj [II ${ }^{\text {nd }}$ contest "Composer of the XXI century". $1^{\text {st }}$ stage. Duet of Anna Subanova and Darya Korkina]. URL: https://www.youtube.com/watch? v=aPmuzg4uSnQ (25.04.2020). [In Russ.].

6. Burjaty, mify, legendy i predanija : otryvok iz nauchnoj raboty [The Buryats, myths, legends and stories : abstract from the scientific work] // Irkipedija.ru : enciklopedija i novosti Priangarja [Irkipedia.ru : encyclopedia and news of Priangarye]. URL: http://irkipedia.ru/content/buryaty_mify_legendy_i_predaniya (17.03.2020). [In Russ.].

7. Korkina Darja Leonidovna [Korkina Darya Leonidovna] // Sojuz Kompositorov Rossii : Vserossijskaja obshchestvennaja organizacija [The Union of the Composers of Russia : All-Russian public organization]. URL: https://unioncomposers.ru/composer/view/?id=272 (28.03.2020). [In Russ.].

8. Mezhdunarodnyj konkurs kompozitorov imeni Jurija Falika 02.07.2012 [The Interntational contest of composers named after Yury Falik 02.07.2012] // RGMC. Rossijskij gosudarstvennij muzikal'nij teleradiocentr [RSMC. Russian state musical teleradio center]. http://www.muzcentrum.ru/news/2012/07/9465-mezhdunarodnyj-konkurskompozitorov-imeni-yuriya-falika (28.03.2020). [In Russ.]. 
DOI 10.31443/2541-8874-2020-3-15-29-34

УДК 688.721(47+57)«20»

Тимошенкова А. М., Кириллова Н. К.

Timoshenkova A. M., Kirillova N. K.

АТРИБУЦИЯ КУКЛЫ ХХ ВЕКА, СПЕЦИФИКА И ПРОБЛЕМЫ РЕСТАВРАЦИИ

\section{ATTRIBUTION OF THE XX CENTURY'S DOLL, SPECIFICS AND PROBLEMS OF RESTORATION}

В статье представлена атрибуция, поступившей на реставрацию куклы, изготовленной из материалов XX века, рассмотрены её историкокультурные особенности. Составлена историческая справка о развитии кукольной промышленности в СССР, обусловленной появлением новых видов материалов. Рассмотрены идеологические особенности советской игрушки. Обозначена проблема сложности предреставрационных исследований объектов, выполненных в смешанных техниках, показана необходимость данных исследований для проведения реставрационных работ. Рассмотрена проблема реставрации кукол-игрушек XX века.

The article presents the attribution of the doll received for restoration which was made from the materials of the XX century and considers its historical and cultural features. The document concerning the history of the doll industry development in the USSR, due to the emergence of new types of materials, has been compiled. The ideological features of the Soviet toy have been considered. The problem of the complexity of pre-restoration studies of the objects made in mixed techniques has been outlined, the necessity in those studies for doing the restoration work has been shown. The restoration problem of the toy dolls of the $\mathrm{XX}$ century has been considered.

Ключевые слова: история советской куклы, реставрация пластмасс, проблемы научной реставрации.

Keywords: history of the Soviet doll, restoration of plastics, problems of scientific restoration.

В двадцатом веке промышленная революция повлияла на все сферы жизни общества, появилось множество новых искусственных материалов, которые обладают широким спектром эксплуатационных свойств при небольших затратах на производство. Не могли они не затронуть и кукольную промышленность, так хрупкие и дорогие фарфоровые куклы стали заменяться игрушками из новых более пригодных для игры материалов. Однако, вместе с удешевлением материалов и массовостью производства изменилось и отношение к куклам: если ранее кукол могли себе позволить только зажиточные граждане, которые покупали их для демонстрации нарядов и декора интерьера, то со сменой материалов кукла стала в первую очередь игрушкой. 
В России куклы из новых материалов стали появляться после революции. В Советском Союзе в двадцатые годы было ограничено производство игрушек. Исследователь М. С. Костюхина высказывает мнение, что политика государства была направлена на то, что игрушками для ребенка должны служить настоящие инструменты, которые с детства привили бы любовь к трудовой коллективной деятельности [3]. Кукол, в те годы покупали только на ярмарках и в маленьких лавочках у кустарей-одиночек. Это связано, в первую очередь, с упадком промышленности, из-за войн и революции, которые разорили страну. Послереволюционная литература превозносила идею детского труда, тем самым выполняя государственные заказы. Такое направление в воспитательной политике было вызвано как идеологией нового государства, так и недоступностью игрушек для части населения, из-за ограниченности производства и высоких цен. Однако, власти быстро поняли, что игрушки играют важную роль в воспитании ребенка, в формировании его мировоззрения. И уже через несколько лет в городах с традиционными народными промыслами восстанавливаются фабрики [4].

Работу по устранению дефицита игрушек проводили на всех этапах производства. Одним из способов решения проблемы поставки сырья стало использование отходов других производителей, в частности заводов и фабрик, разрабатывающих новые рецептуры целлулоида и резины. Также особенностью советской игрушки было то, что она часто являлась на предприятии попутной продукцией. Например, Охтинский химкомбинат специализировался на производстве пороха для пушек, и в технологии использовался целлулоид, которого оставалось много. Его стали применять для игрушек, открыли для этого специальный цех №6 [5]. Швейные мастерские на комбинате отсутствовали, поэтому кукол продавали без одежды, выпускали так называемых «голышек», и, желающим их «одеть» покупателям приходилось шить платья самостоятельно. Несмотря на это, предприятие производило по 5 млн. кукол в год. Такой подход негативно сказывался на разнообразии и дизайне кукол, но позволял достаточно быстро наладить их выпуск [6].

В истории развития советской куклы особое место занимает её воспитательная направленность. В 1930-е гг. началась разработка новых кукол, образы которых должны были отражать эпоху и нового человека - строителя социализма. В городе Загорске в 1932 году был открыт Всесоюзный научно-исследовательский институт игрушки, у него также был филиал в городе Вятке. Институт стал единственным в мире научным учреждением по данному профилю [4]. Новые образы игрушек должны были формировать новый тип личности, который бы основывался на социалистических ценностях, стереотипах и нормах. Помощниками в этом стали периодические издания, например, журнал «Советская игрушка» (в 1937 году переименован в «Игрушка»). В одном из номеров этого журнала писали, что детская игрушка является мощным оружием коммунистического воспитания, чувствительным идеологическим инструментом, поэтому производство ее должно быть под непосредственным идейно-политическим контролем [4]. $\mathrm{B}$ образах игрушек прослеживалась идеологизация, популярными образами были пионеры, солдатики-красноармейцы, крестьяне, рабочие [1]. 
Основным типом кукол были динамично-подвижные, эстетически просто оформленные различного размера и художественного решения, в тканевых костюмчиках или «голышки». Такие куклы привлекали родителей и детей широкими игровыми возможностями, благодаря подвижным ручкам и ножкам, и своей непосредственной схожестью с ребенком; играя с куклой малыш мог перевести на нее свои желания [2].

В СССР куклы и игрушки были самостоятельными художественными произведениями, которые призывали к эмоциональной зрелости. Художник через игрушку говорил о добре, об искренности, о честности, он хотел нести радость детям [5]. Перед тем как советская кукла попадала на производство, она проходила многоступенчатый и длительный процесс одобрения художественным советом. Вначале художник делал эскизы, затем определялся с материалом, после лепил образ из пластилина. Именно этот пластилиновый, несовершенный образ поступал на первый художественный совет, на фабрику, оценивали технологическую сторону — размеры, удобность изготовления. Далее была формовка в гипсе, которая покрывалась акварелью - теперь оценивалась эстетическая составляющая. И только после одобрения делалась рабочая модель идеальной формы, в материале - и снова художественный совет. Процесс утверждения игрушки мог длиться несколько месяцев, некоторые образцы утверждали больше года [5].

Ярким примером куклы-младенца с пухлыми щечками, розовыми ручками и ножками и озорной улыбкой, который отражал образ здорового и счастливого советского ребенка, является кукла, поступившая на реставрацию в мастерские Санкт-Петербургского государственного института культуры.

Памятник поступил в реставрацию из частной коллекции. Кукла была подарена хозяйке на Урале, в эвакуации во время Великой Отечественной войны (ориентировочно 1943-1945 гг.), в то время хозяйка была еще ребенком и памятник, в первую очередь, служил игрушкой.

Данные куклы выпускались заводом им. Косякова с начала 1930-х гг. до начала 1950-х гг. В 1930-е годы Рошальский завод был инициатором внедрения в пороховую промышленность древесной целлюлозы. А также первым стал производить нитраты целлюлозы, которые использовались для изготовления пластмасс, целлулоида, нитролаков, нитроэмалей, бездымного пороха, динамита [7]. Несмотря на то, что вся промышленность во время Великой Отечественной войны была направлена на военные нужды, выпуск игрушек на заводе, являлся попутным, и не останавливался в даже в то время, так как военная промышленность, особенно специализирующаяся на производстве пороха, имела большое количество отходов, которые использовали для производства игрушек. В частности, для кукол подходили остатки целлулоида, дешевый композит и недорогие ткани.

Во время игры к кукле относились бережно, с любовью, так как игрушек у военных детей было мало, а плачущая кукла (в туловище памятника находится механизм, издающий короткий плач) была особой редкостью. В ходе эксплуатации было утрачено родное платье, остались только синие шорты и белая майка, износ родной одежды обусловлен дешевизной исполь- 
зуемых при производстве тканей. Новые верхние шорты и платье были сшиты хозяйкой в 1950-ые годы.

История бытования куклы с 60-х годов XX века до начала XXI века достоверно неизвестна, известно только, что кукла хранилась в квартире, предположительно памятник могли использовать как игрушку еще какое-то время, после перевозить в коробке, как памятную вещь. Также неизвестно когда именно были получены механические повреждения головы, предположительно во время одного из переездов коробку с куклой или саму куклу уронили. С 2003 г. по 2018 г. памятник находился в нежилом неотапливаемом загородном доме, где были постоянные изменения температурновлажностного режима, которые привели к разрушению лакокрасочного покрытия на руках и ногах куклы. В конце 2018 года куклу нашли, и было принято решение передать ее на реставрацию.

Сегодня памятник представляет историческую ценность, как объект военной советской мануфактуры, которая, несмотря на войну, продолжала работу не только по производству оружия, но и по производству игрушек. Также кукла является памятником советской идеологии, игрушки в те времена были направлены на формирование нового типа личности - трудящегося человека. Кукла-малыш с розовыми щечками должна была привить детям навыки заботы и ответственности.

Куклу можно рассмотреть как художественный памятник. Образы для игрушек прошлого века тщательно разрабатывались художниками, которые передавали через них свои мысли о доброте, радости, искренности, они были способом донесения идеалов художника и советской идеологии подрастающему поколению.

Также кукла стала семейной реликвией, вещью, которая наполнена важными воспоминаниями. Когда-то памятник был любимой игрушкой, ценностью и сокровищем для ребенка, сейчас он стал частью семейной истории, которую важно и хочется сохранять и передавать следующим поколениям.

На момент поступления в реставрацию памятник находится в аварийном состоянии и требует реставрационного вмешательства. Специфика работы определяется разнообразием используемых для создания куклы материалов: голова выполнена из полимерного материала, ручки и ножки из покрытого краской композитного материала, туловище тканевое со встроенным механизмом короткого плача, таким образом, данные материалы требуют разных реставрационных подходов. Реставрационное вмешательство в поступивший на реставрацию памятник возможно только на основе историко-художественных и технико-технологических исследований, они позволят составить полное представление о структуре и особенностях материалов объекта, рассмотреть причины и виды разрушений, например, голова выполнена из полимеров, вид которых определить с помощью зрительного осмотра не представляется возможным, необходимо проведение качественного анализа.

Реставрация памятников XX века, выполненных из искусственных материалов, представляет собой широкий спектр вопросов, как в разработке 
методик, так и в подборе реставрационных материалов, которые отвечали бы предъявляемым к ним требованиям: они должны не искажать авторский замысел, не препятствовать повторной реставрации и быть долговечными. Так как на сегодняшний день реставрацией подобных объектов с научной стороны подробно никто не занимался, данный вид работ с большей вероятностью можно было бы рассматривать как ремонт. Мастера-художники, любители и коллекционеры занимаются сохранением памятников XX века, в частности кукол, зачастую ремонтируют их подручными материалами, чтобы спасти от полного разрушения.

В современном обществе параллельно можно наблюдать два процесса: одной стороны наблюдается рост интереса к подобным памятникам, а с другой, их стремительное исчезновение, связанное как с пренебрежительным отношением со стороны бывших владельцев, так и отсутствием научнообоснованного подхода к их реставрации и консервации. Таким образом, можно судить, что пришло время для проведения исследований и разработки реставрационных методик для объектов, выполненных из новых материалов, разработанных в XX веке.

\section{Примечания}

1. Смирнова Е. О., Соколова М. В. История европейских и отечественных игрушек // Современная зарубежная психология. 2016. № 5/1. С. 3238.

2. Иванова Е. С. Психологический анализ специфики изменения образа куклы // Вестник ТГУ. 2011. № 12.

3. История советской игрушки // StudFiles : [сайт]. URL: https://studfile.net/preview/6019308/ (дата обращения: 15.01.2020).

4. Мишина Ю. Игрушка: история и современность // Победа : информационный портал Аксайского района. 03.08.2018. URL: http://www.pobeda-aksay.ru/2018/08/03/igrushka-istoriya-i-sovremennost/ (дата обращения: 16.01.2020).

5. Орехова Н. Почему советские игрушки лучше тех, что делают теперь // Город 812. Петербургский журнал. Мысли о городе и мире : Электронная версия журнала. 08.06.2018. URL: http:/gorod-812.ru/pochemusovetskie-igrushki-luchshe-teh-chto-delayut-teper/ (дата обращения: 18.01.2020).

6. Усачев M. Кукла // RETAILED.ru : [сайт]. URL: https://retailer.ru/sovetskaja-torgovlja-strana-strashnyh-igrushek/ (дата обращения: 13.01.2020).

7. Рошальский химический комбинат им. А. А. Косякова // LiveJournal. 25.02.2012. URL: https://bronetractor.livejournal.com/2588.html (дата обращения: 20.01.2020).

\section{References}

1. Smirnova Ye. O., Sokolova M. V. Istorija evropejskikh i otechestvennykh igrushek [The history of European and national toys] // Sovremennaja zarubezhnaja psikhologija. 2016. №5/1. Pp. 32-38 [In Russ.]. 
2. Ivanova Ye. S. Psikhologicheskij analiz specifiki izmenenija obraza kukly [Psychological analysis of the change of the specifics of a doll' image // Vestnik TGU [Bullettin of TSU]. 2011. № 12 [In Russ.].

3. Istorija sovetskoj igrushki [The history of the Soviet toy] // StudFiles : [sajt] [StudFiles : [site]. URL: https://studfile.net/preview/6019308/ (15.01.2020) [In Russ.].

4. Mishina Ju. Igrushka: istorija i sovremennost' [Toy: history and modernity] // Pobeda: information portal of the Aksakay district]. 2018. URL: http://www.pobeda-aksay.ru/2018/08/03/igrushka-istoriya-i-sovremennost/ (16.01.2020) [In Russ.].

5. Orekhova N. Pochemu sovetskije igrushki luchshe tekh, chto delajut teper' [Why are the Soviet toys better that those made at present] // Gorod 812 Peterburgskij zhurnal. Mysli o gorode i mire : Electronnaja versija zhurnala [City 812. The journal of St.-Petersburg. Thoughts about the city and the world : Electronic magazine version]. 2018. URL: http://gorod-812.ru/pochemu-sovetskieigrushki-luchshe-teh-chto-delayut-teper/ (18.01.2020) [In Russ.].

6. Usachev M. Kukla [A Doll] // RETAILED.ru [sajt] [RETAILED.ru : [site]. URL: https://retailer.ru/sovetskaja-torgovlja-strana-strashnyh-igrushek/ (13.01.2020) [In Russ.].

7. Roshal'skij khimicheskij kombinat im. A. A. Kosjakova // Roshal chemical mill named after A.A. Kosyakov // LiveJournal. 25.02. 2012. URL: https://bronetractor.livejournal.com/2588.html (20.01.2020) [In Russ.]. 
кУЛЬТУРОЛОГИЯ

DOI 10.31443/2541-8874-2020-3-15-35-45

УДК 930.85(571.5)

Дементьева В. В.

Dementyeva $V . V$.

\section{ФОРМИРОВАНИЕ КУЛЬТУРНЫХ ИНСТИТУТОВ В ГОРОДАХ ВОСТОЧНОЙ СИБИРИ (ВТОРАЯ ПОЛОВИНА ХІХ - НАЧАЛО ХХ ВВ.)}

\section{CULTURAL INSTITUTIONS FORMATION IN THE CITIES OF EASTERN SIBERIA (THE SECOND HALF OF THE XIX-BEGINNING OF THE XX CENTURIES)}

В статье рассмотрены особенности формирования культурных институтов в городах Прибайкалья и Забайкалья. Показана роль научных обществ, ученых, политических ссыльных, разночинной интеллигенции, торговых и промышленных предпринимателей в создании и развитии музеев, библиотек, театрально-зрелищных объединений в Иркутске, Верхнеудинске, Чите, Нерчинске, Кяхте во второй половине XIX - начале XX вв.

The article considers the features of cultural institutions formation in the cities of the Pre-Baikalia and Transbaikalia. The role of scientific societies, scientists, political exiles, various intelligentsia, trade and industrial entrepreneurs in the creation and development of museums, libraries, performing societies in Irkutsk, Verkhneudinsk, Chita, Nerchensk, Kyakhta in the second half of the XIX early XX centuries is shown.

Ключевые слова: культурный институт, библиотеки, музеи, театрально-зрелищные объединения, Восточная Сибирь, Прибайкалье, Забайкалье.

Keywords: cultural institute, libraries, museums, performing societies, Eastern Siberia, the Baikal region, Transbaikalia.

Вторая половина XIX - начало XX вв. - это период в истории России связан с модернизационными процессами, которые затронули самые важные сферы общества: политическую, социально-экономическую, образования и культуры. Одним из следствий проводимых реформ стало интенсивное формирование культурных институтов, которые рассматривались, с одной стороны, как необходимые инструменты просветительского движения, а с другой - как важный механизм пропаганды политики государства.

По мнению А.Я. Флиера, дефиниция «культурный институт» имеет непосредственное и расширительное толкование. В первом случае речь будет идти об организации, которая выполняет функции создания, хранения, регулирования и транслирования культурного продукта (библиотеки, музеи, театры, учебные заведения, филармонии, творческие союзы, научно- 
исследовательские институты и т.д.). Расширительная трактовка данного термина подразумевает деятельность, которая сложилась стихийно, но имеет высокую социальную значимость для определенного общества (нравы, традиции, обычаи и т.п.) [18].

В нашей статье мы будем придерживаться непосредственной трактовки культурного института, определим особенности формирования библиотек, музеев, театрально-зрелищных объединений в городах Восточной Сибири во второй половине XIX - начале XX вв.

Созданию музеев в Сибири способствовал интерес местной интеллигенции, политических ссыльных к изучению края. Большое внимание исследователи уделяли изысканиям в области геологии, метрологии, зоологии, археологии, ботаники и др. Был собран обширный материал по хозяйственному укладу, быту, фольклору, традициям и обычаям автохтонных народов и переселенцев. Решающую роль в организации масштабных исследований (экспедиций) сыграло Императорское Русское Географическое Общество, главной целью которого стало утверждение стратегических и геополитических интересов российского государства на обширной территории Сибири и Дальнего Востока [16]. Сибирский отдел ИРГО создан 17 ноября 1851 года в Иркутске, а в 90-х гг. открылись Читинское Отделение Приамурского Отдела ИРГО (ЧОПОИРГО) и Троицкосавско-Кяхтинское Отделение ИРГО (ТКОПОИРГО) в Кяхте [3].

Научные общества стали своеобразными плацдармами для институционального оформления предметов коллекционирования и появлением первых региональных музеев. Одним из старейших музеев Сибири является Иркутский, созданный ещё в 1782 году. Однако развитие и становление музея как крупнейшего центра по изучению края связывают с деятельностью СОИРГО в Иркутске. После передачи музея Географическому Обществу в 1854 году, его собрания активно пополняются за счет пожертвований и материалов, полученных в ходе различных экспедиций [14]; осуществляется регулярное экспонирование коллекций на выставках разного уровня (Казань, Москва, Париж). Благодаря деятельности выдающихся ученых и общественных деятелей в музее велась научно-исследовательская, просветительская работа.

Решающую роль в организации музеев сыграли не только научные общества, но и политические ссыльные, разночинная интеллигенция, купцы, которые вносили денежные средства на содержание данных культурных институтов, оказывали помощь в пополнении коллекций, а также являлись инициаторами создания многих музеев. Одной из таких личностей был бывший политический ссыльный А.К. Кузнецов. С его именем связано образование Нерчинского публичного музея в 1886 году, открытие Читинского отделения Приамурского отдела Императорского Русского Географического общества в 1894 году и основание Забайкальского областного музея в 1895 году как структурного подразделения ЧОПОИРГО [4; 15$].$

Идея создания музея в Троицкосавске также принадлежала политическим ссыльным И.И. Попову и Н.А. Чарушину. Их поддержала местная интеллигенция, известный ученый-путешественник Г.Н. Потанин. Однако 
вопрос о статусе музея еще долго оставался нерешенным. Только после организации в Кяхте отделения ИРГО в 1894 году, музей вошел в его ведение и стал официальным учреждением, а в 1895 году был открыт для посещений [12].

Совершенно иначе происходил процесс оформления публичного музея в Верхнеудинске. Несмотря на неоднократные попытки его создания со стороны Верхнеудинской городской думы и интеллигенции в начале XX века, сделать это было достаточно сложно. Во-первых, не способствовала этому социально-политическая и экономическая ситуации в стране (первая мировая война и революционная обстановка). Во-вторых, идея образования отдела ВСОИРГО возникла значительно позже, чем в других уездных городах Забайкалья. Лишь в 1916 году местной интеллигенцией было подано ходатайство об учреждении отделения ИРГО в городе Верхнеудинск [3]. Планировалось, что появление данного отделения благоприятно скажется на организации музея и изучении прилегающих территорий. Большая работа по сбору материала о крае и формированию музея была проделана «Обществом изучения Прибайкалья». Однако музей был создан только в 1923 году, в первые годы советской власти.

Финансирование общественных музеев осуществлялось разными способами: это могли быть поступления от учредителя или инициатора создания музея (городское самоуправление, членские взносы) либо частные пожертвования населения. Кроме того, разночинная интеллигенция часто организовывала спектакли, концерты, чтения лекций, а полученные от этих мероприятий средства направляла на развитие музеев.

Что касается востребованности этих заведений среди населения, то, по данным разных источников [14; 17], основную группу посетителей составляли воспитанники учебных заведений, горожане. Для популяризации знаний о крае и сопредельных территориях проводились объяснительные чтения. Тематика и содержание чтений зависели от уровня подготовленности публики и имеющихся в фондах музея коллекций.

Как правило, организация музеев во многих городах стала возможной благодаря их выгодному политическому, экономическому и административно-территориальному положениям. Например, Иркутск - торговый и административный центр Восточной Сибири. Нерчинск являлся крупным горнопромышленным городом. Троицкосавск - приграничный город, пункт русско-китайской торговли.

Еще до появления общественных музеев в городах Восточной Сибири было распространено частное коллекционирование различных предметов среди представителей местного купечества. Например, частный музей А.M. Курбатова в г. Верхнеудинск и М.А. Зензинова, М.Д. Бутина в г. Нерчинск.

Таким образом, формирование и развитие музеев на территории Восточной Сибири было закономерным явлением, следствием модернизационных процессов, происходивших в Российской империи в 60-70-х годах XIX столетия. Важную роль в организации музейного дела сыграло Русское Географическое Общество, а также известные ученые, политические ссыльные, разночинная интеллигенция, местная буржуазия. Общественные музеи за- 
частую создавались в крупных городах - административных, промышленных, торговых центрах при отделениях ИРГО и выполняли функции научноисследовательских и просветительских учреждений.

Наряду с музеями, культурно-просветительские и образовательные задачи решали и библиотеки. В губернских и уездных городах Восточной Сибири имелись библиотеки разных видов: научные, церковные, школьные, городские, общественные, частные и другие. В организации научных библиотек большую роль сыграло ИРГО. Известно, что при данном обществе создавались как музеи, так и библиотеки, многие из которых впоследствии выполняли функции публичных.

При Читинском отделении Приамурского отдела Императорского Русского Географического общества функционировала библиотека (1895), которая должна была содействовать ученым в исследовании края. Но ситуация сложилась таким образом, что ввиду низкого уровня грамотности населения и отсутствия городской библиотеки, научная библиотека стала решать еще и задачи публичной, ориентированной на культурно-просветительские цели. В формировании ее фонда приняли участие общественность города, политические ссыльные, разночинная интеллигенция, купцы и др. В разные годы в дар библиотеке переданы частные книжные коллекции краеведа А.К. Кузнецова, врача Н.В. Кирилова, действительного члена ИРГО И.Ю. Турнефора, собрания из книгохранилищ императора Николая II и др. [2]. Пользователями библиотеки были как сотрудники отделения, так и население города. В целях доступности фонда малоимущим гражданам предоставлялись некоторые льготы.

В связи с недостаточностью средств на содержание и комплектование библиотеки в 1909 году она была передана в ведение Читинского городского самоуправления. С этого времени в ЧОПОИРГО продолжала работать только научная библиотека [2].

Одной из старейших публичных библиотек Сибири являлась Иркутская, основанная в 1861 году на пожертвования горожан. С 1864 года она находилась в ведении Городского общества. Фонд библиотеки пополнялся в основном за счет частных коллекций (В.И. Вагин, М.П. Шестунов и др.), а после пожара 1879 года денежные и книжные пожертвования на восстановление библиотеки стали поступать из многих городов России. В связи с увеличением книжных собраний, количества абонентов, в конце 80-х годов XIX века встал вопрос об изучении состояния и реорганизации библиотеки. По результатам проверки было направлено ходатайство в думу о повышении ассигнований на приобретение книг и журналов и получен положительный ответ [9]. К началу XX в. библиотека располагала богатым книжным собранием. Наряду с платным абонементом, в библиотеке имелся бесплатный читальный зал [8].

Создание в Нерчинске городской общественной библиотеки относят к 1876 году, но ее активная деятельность начинается с 1886 г., когда был сформирован особый комитет, который начал заниматься делами библиотеки. Пополнение фонда осуществлялось за счет пожертвований местной интеллигенции, купечества (М.М. Зензинов, И.М. Сибиряков и др.). Значи- 
тельная материальная поддержка библиотеке была оказана членами Чайного клуба (с 1886 года - Нерчинский кружок любителей музыки и литературы) во главе с А.И. Шумихиным. Следует отметить, что представители кружка составляли основное ядро пользователей библиотеки. Благодаря их активному участию в деятельности данного учреждения уже к концу XIX столетия увеличилось количество постоянных читателей, регулярно выписывались периодические издания, пополнялся фонд библиотеки. Большой вклад в развитие библиотеки внесли: И.В. Багашев, М.Ф. Суровцев, А.Н. Малевич, Г.А. Стуков и другие. Например, политический ссыльный М.М. Чернавский несколько лет бесплатно работал библиотекарем, был одним из составителей каталога Нерчинской библиотеки [13].

Однако, в начале XX в. положение Нерчинской общественной библиотеки значительно ухудшилось. Причиной этому послужили сложная социально-политическая, экономическая ситуация в предреволюционной имперской России; отъезд многих пассионарных личностей, составлявших «культурное гнездо» края и являвшихся инициаторами различных прогрессивных начинаний в области науки, культуры, образования; невыгодное территориальное положение города вдали от железной дороги.

Одна из первых общественных библиотек в Забайкалье была открыта в 1881 году в г. Верхнеудинск. Попытки создания библиотеки предпринимались неоднократно, о чем свидетельствуют различные источники [1; 7; 17]. Организатором и первым управляющим библиотеки стал штатный смотритель Верхнеудинского уездного училища Н.С. Нелюбов. Согласно уставу, библиотека являлась собственностью города, однако субсидии на ее содержание выдавались небольшие. Как и во многих публичных библиотеках, фонд пополнялся за счет пожертвований горожан: купцы, разночинная интеллигенция. Наиболее значительный дар в виде книг и журналов был сделан купцом Д.А. Меньшиковым.

Несмотря на заявленный общественный статус, пользование библиотекой было платное и зависело от разряда подписчика, каждый из них обладал определенными правами в соответствии с внесенной суммой [17]. Тем не менее, некоторым малоимущим гражданам, по особому ходатайству городской управы, разрешалось льготное посещение библиотеки, о чем упоминает в своей монографии И.Ю. Замула.

Вопрос о необходимости создания в г. Кяхта общественной библиотеки впервые возникает еще в 60-е гг. XIX века и связан с именем градоначальника А.И. Деспот-Зеновича. Известно, что она просуществовала до 70-х годов XIX в. Позднее, в 1887 г., инициаторами открытия публичной библиотеки становятся политические ссыльные И.И. Попов и супруги Н.А и А.Д. Чарушины. Идея ее создания была поддержана городским главой М.О. Осокиным, который передал в дар приобретенную им частную библиотеку. Для решения организационных вопросов формируется выборный Распорядительный Совет и Попечительский комитет, в состав которого в разные годы входили: Ю.Д. Талько-Гринцевич, П.С. Михно, А.Д. Старцев и др. [11].

Основными источниками финансирования библиотеки являлись: пожертвования горожан, городская субсидия, абонементная плата, взносы 
членов попечительского совета, а также средства, полученные от различных мероприятий (концерты, лекции), проводимых разночинной интеллигенцией [1]. Благодаря меценатам и активной позиции городской управы, фонды Троицкосавской библиотеки пополнялись быстрее, чем Верхнеудинской. В начале XX века (1907 г.) количество выписываемых журналов и газет было больше, чем в публичных библиотеках гг. Иркутск и Нерчинск [11]. Тем не менее за пользование библиотекой взымалась плата.

Еще до организации общественных библиотек многие из числа просвещенной интеллигенции, купечества имели личные книжные собрания. В г. Иркутск были известны частные библиотеки М.П. Шестунова, В.И. Вагина. Владельцами крупных книжных коллекций в г. Нерчинск были М.M. Зензинов, М.Д. Бутин. В г. Верхнеудинск значительными личными библиотеками владели Д.А. Меньшиков, А.П. Лосев, М.В. Танский. Крупные книжные собрания в Троицкосавске имелись у А.М. Лушникова, И.М. Немчинова и др. Некоторая часть книг из личных собраний была передана в дар на развитие общественных библиотек.

Таким образом, появление публичных библиотек в губернских и уездных городах Восточной Сибири во второй половине XIX столетия связано с деятельностью научных обществ, местной интеллигенции, политических ссыльных, купцов. Необходимо отметить, что важную роль в организации данных учреждений сыграло Русское Географическое Общество, члены которого во многом способствовали созданию общественных библиотек. Зачастую открытие библиотек было личной инициативой и, как правило, после переезда инициатора, работа их либо прекращалась, либо велась не на должном уровне. Поэтому попытки образования публичных библиотек в регионе предпринимались неоднократно. Несмотря на заявленный публичный статус, фонды библиотек были доступны ограниченному кругу лиц, в зависимости от вносимой платы. Общественные библиотеки, как и музеи, являлись важными научными, культурно-просветительными учреждениями, которые способствовали формированию культурного пространства региона во второй половине XIX - начале XX вв.

В этом процессе значительную роль сыграли любительские объединения литературной, музыкальной, театральной направленности. Интерес к театральному искусству в Предбайкалье и Забайкалье появился в среде разночинной интеллигенции, торговых и промышленных предпринимателей. Если в г. Иркутск уже действовал профессиональный театр с 1850-х гг. [5; 10], то во многих уездных городах только к концу ХІХ столетия возникают любительские театральные кружки.

Одним из первых объединений подобного рода считается Нерчинский кружок музыки и литературы, созданный в 1886 г. Деятельность кружка поддерживалась крупным меценатом М.Д. Бутиным, по инициативе которого в 1874 г. открыто Нерчинское отделение императорского русского музыкального общества [6; 13]. Благодаря его поддержке было построено специальное театральное здание и передано в пользование кружка. В отличие от других любительских групп, в Нерчинске сложились благоприятные условия для развития театрального искусства. По мнению Е.М. Дележи, ос- 
новная деятельность этого объединения была сосредоточена на популяризации музыкальной культуры и литературы посредством проведения музыкально-драматических и литературных вечеров, постановок спектаклей. Наряду с этим, члены кружка организовывали чтение публичных лекций, посвященных литературе, музыке, театру; оказывали материальную помощь различным учреждениям и нуждающимся людям творческих профессий [6].

Аналогичные любительские общества учреждаются и в других городах: Верхнеудинск, Чита, Кяхта. В 1887 г. создается «Троицкосавское литературно-музыкальное общество» под руководством купцов А.М. Лушникова и Г.С. Синицина с целью объединения, поддержки, выявления талантливых людей и развития различных видов искусств. В Верхнеудинске, в 1880 г., по инициативе смотрителя уездного училища Н.С. Нелюбова ставятся первые любительские спектакли, а с 1891 года официально зарегистрирован кружок актеров-любителей [7; 17]. Появление группы любителей музыки, литературы и драматического искусства в Чите (1895 г.) связано с именем политического ссыльного А.К. Кузнецова [15].

Большое значение для последующего формирования профессиональных театров в Забайкалье имело не только наличие любительских кружков драматического и музыкального направления, но и гастроли актеров Иркутского театра, выступление выдающихся артистов России, а также деятельность антрепренеров. Как правило, от хорошо организованной работы антрепренера во многом зависел успех спектакля, так как в его обязанности входили подбор актуального репертуара и формирование труппы. Необходимо отметить, что благодаря совместной игре профессионалов и любителей, начинающие актеры перенимали опыт, повышали уровень своего мастерства, а также знакомились с последними новшествами в мире искусства.

Репертуарная политика в отношении профессионального и любительского театров строилась исходя из соответствующих предписаний надзорных органов, например, «Полного алфавитного списка драматических сочинений на русском языке, одобренных к представлению на сценах народных театров» (1897 г.) и включала в основном произведения развлекательного характера. Однако, по мнению некоторых исследователей [7; 17], местные театральные коллективы любителей обращались и к более содержательным художественным сочинениям. Особенно отчетливо это тенденция прослеживалась в начале XX в., в период первой русской революции, в связи с ослаблением цензуры.

Рассматривая деятельность театрально-зрелищных объединений в обозначенный период, отметим следующие моменты: 1) появление любительского театра и его дальнейшее развитие в регионе зависело от инициативы местной интеллигенции, торговых и промышленных предпринимателей, а также поддержки городской власти; 2) как правило, в состав кружков входили купечество, представители разночинной интеллигенции, многие из которых впоследствии стали профессиональными актерами (например, члены Нерчинского кружка); 3) любительские объединения музыкального и драматического искусства выполняли образовательные, воспитательные, культурно-просветительские функции; оказывали благотворительную по- 
мощь; формировали благоприятную культурную среду для возникновения профессионального театра; 4) наряду с любительскими обществами, в некоторых крупных городах функционировали профессиональные театры (г. Иркутск, 1851 г., г. Чита, 1911 г.).

Таким образом, формирование и развитие культурных институтов в городах Забайкалья и Прибайкалья было закономерным явлением, следствием ряда либеральных реформ, проводимых правительством Российской империи в 60-70-х годах XIX столетия. Появление музеев, библиотек, театрально-зрелищных объединений связано с деятельностью научных обществ, инициативой известных ученых, политических ссыльных, разночинной интеллигенции, предпринимателей. Наиболее выгодное положение в оформлении соответствующих институтов было у крупных губернских городов, торгово-промышленных центров. Дальнейшее развитие данных учреждений во многом определялось заинтересованностью в них властных структур.

\section{Примечания}

1. Бадлаева Т. В. История светских библиотек в Забайкалье (вторая половина ХІХ в. - февраль 1917 г.). Улан-Удэ : Изд-во БНЦ СО РАН, 2008. C. $14-42 ; 101-117$.

2. Базылева Е. А. Роль Читинского отделения Приамурского отдела Императорского Русского географического общества в развитии книжной культуры Забайкалья // Книга: Сибирь - Евразия : труды 1 Междунар. науч. конгресса. Новосибирск : ГПНТБ СО РАН, 2016. Т. 2. С. 179-187. URL: https://elibrary.ru/item.asp?id=30027676 (дата обращения: 21.01.2020).

3. Бандура Е. М. К вопросу об истории музейного строительства в Забайкалье начала XX в. // Вестник Томского гос. ун-та. 2008. № 309. URL: https://elibrary.ru/item.asp?id=10338331 (дата обращения: 21.01.2020).

4. Бураева С. В., Мишакова О. Э., Саяпарова Е. В. Музейное дело Бурятии в конце XIX в. - первом десятилетии XXI в.: формирование, развитие и современное состояние. Улан-Удэ : Изд.-полигр. комплекс ВСГАКИ, 2012. C. 27-46.

5. Воронова М. В. История театра и театрального искусства Восточной Сибири: региональные особенности // Вестник Санкт-Петерб. гос. ун-та. Серия 2. История. 2012. № 4. URL: https://cyberleninka.ru/article/n/istoriyateatra-i-teatralnogo-iskusstva-vostochnoy-sibiri-regionalnye-osobennosti (дата обращения: 15.04.2020).

6. Дележа Е. М. Формирование русского театра в Забайкалье (вторая половина XIX - начало XX вв.). Улан-Удэ : Изд.-полигр. комплекс ВСГАКИ, 1997. $111 \mathrm{c.}$

7. Замула И. Ю. Городская культура и общественный быт Верхнеудинска (1875 - февраль 1917). Иркутск : Облмашинформ, 2001. С. 114-131.

8. Иркутская городская публичная библиотека. URL: http://irkipedia. ru/content/irkutskaya_gorodskaya_publichnaya_biblioteka (дата обращения: 06.04.2020).

9. Иркутская публичная библиотека. URL: https://www.irklib.ru/about /istoriya-biblioteki (дата обращения: 06.04.2020). 
10. Иркутский академический театр им. Н. П. Охлопкова. URL: http://irkipedia.ru/node/42191/talk (дата обращения: 10.04.2020).

11. История Кяхтинской библиотеки // Библиотечное дело Республики Бурятии в лицах. URL: http://baikal-center.ru/bibliodelo/?page_id=318 (дата обращения: 10.04.2020).

12. Мишакова О. Э. Специфика организации музейной практики в Западном Забайкалье в конце XIX - начале XX в. // Вестник Томского гос. ун-та. 2015. № 394. URL: https://cyberleninka.ru/article/n/spetsifika-organizatsiimuzeynoy-praktiki-v-zapadnom-zabaykalie-v-kontse-hih-nachale-hh-v (дата обращения: 05.02.2020).

13. Нерчинск. Чита : ЗабГУ, 2013. С. 285-292. URL: http://encycl.chita.ru/encycl/person/?id=8834 (C) Энциклопедия Забайкалья (дата обращения: 06.04.2020).

14. Оглезнева Г. В. Музей как фактор социальной коммуникации во второй половине XIX - начале XX в. (на материалах Иркутской губернии) // Известия Иркутского гос. ун-та. Серия: История. 2012. № 2-2. URL: https://cyberleninka.ru/article/n/muzey-kak-faktor-sotsialnoy-kommunikatsii-vovtoroy-polovine-hih-nachale-hh-v-na-materialah-irkutskoy-gubernii (дата обращения: 21.01.2020).

15. Очерки истории Забайкальского края. Т. 1-2. Чита : Экспресс-издво, 2009. С. 136-147.

16. Павлов К. А. Русское географическое общество: история и современность // Современные проблемы сервиса и туризма. 2010. № 1. URL: https://cyberleninka.ru/article/n/russkoe-geograficheskoe-obschestvo-istoriya-isovremennost (дата обращения: 10.04.2020).

17. Паликова Т. В. Города Забайкалья второй половины XIX - начала $\mathrm{XX}$ в. (социальное, экономическое, культурное развитие). Улан-Удэ : Изд-во Бурят. гос. ун-та, 2010. С. 138-160.

18. Флиер А. Я. Культурный инструментарий социальной политики // Культура культуры. 2016. № 4 (12). URL: https://cyberleninka.ru/article/ n/kulturnyy-instrumentariy-sotsialnoy-politiki (дата обращения: 21.03.2020).

\section{References}

1. Badlaeva T. V. Istorija svetskikh bibliotek v Zabajkalje (vtoraja polovina XIX v.- fevral' $1917 \mathrm{~g}$. [History of public libraries in Transbaikalia (the second part of the XIX century - February of 1917]. Ulan-Ude, 2008. Pp. 14-42 ; 101117. [In Russ.].

2. Bazyleva Ye. A. Rol' Chitinskogo otdelenija Priamurskogo otdela Imperatorskogo Russkogo geograficheskogo obshchestva $\mathrm{v}$ razvitii knizhnoj kyl'tury Zabajkalija [The role of the Chita department of the Imperial Russian geographical society in the development of book culture of Transbaikalia] // Kniga : Sibir' - Jevrazija : Trudy 1 Mezhdunar. nauch.kongressa. [Book: Siberia Eurasia: works of the I Intern. scient. congress]. Novosibirsk, 2016. V. 2. Pp. 179187. URL: https://elibrary.ru/item.asp?id=30027676 (21.01.2020). [In Russ.].

3. Bandura Ye. M. K voprosu ob istorii muzejnogo stroitel'stva $\mathrm{v} Z \mathrm{Za}-$ baikalje nachala XX v. [To the issue of the history of the museum construction in 
Transbaikalia of the XX century] // Vestnik Tomskogo gos. un-ta [Bulletin of Tomsk state university]. 2008. № $309 . \quad$ URL: https://elibrary.ru/item.asp?id=10338331 (21.01.2020). [In Russ.].

4. Buraeva S. V., Mishakova O. E., Sayaparova Ye. V. Muzejnoje delo Burjatii v konce XIX v. - pervom desjatiletii XXI v. : formirovanije, razvitije i sovremennoje sostojanije [Museum business of Buryatia at the end of the XIX c.first decade of the XXI c. : formation, development and modern condition]. UlanUde, 2012. Pp. 27-46. [In Russ.].

5. Voronova M. V. Istorija teatra i teatral'nogo iskusstva Vostochnoj Sibiri: regional'nyje osobennosti [History of theatre and theatre art of Eastern Siberia: regional peculiarities // Vestnik Sankt-Peterb. gos. un-ta. Serija 2. Istorija [Bulletin of Saint-Petersb. state univ. Series 2. History 2012. № 4. URL: https://cyberleninka.ru/article/n/istoriya-teatra-i-teatralnogo-iskusstvavostochnoy-sibiri-regionalnye-osobennosti (15.04.2020). [ In Russ.].

6. Delezha Ye. M. Formirovanije russkogo teatra v Zabajkalje (vtoraja polovina XIX-nachalo XX vv. [The Russian theatre formation in Transbaikalia (second half of the XIX-beginning of the XX century). Ulan-Ude, 1997. $111 \mathrm{p}$.[In Russ.].

7. Zamula I. Yu. Gorodskaja kul'tura i obshchestvennyj byt Verkhdeudinska (1875-fevral' 1917) [City culture and social life of Verkhneudinsk (1856-February of 1917). Irkutsk, 2001. Pp. 114-131. [In Russ.].

brary].

8. Irkutskaja gorodskaja publichnaja biblioteka [Irkutsk city public liru/content/irkutskaya_gorodskaya_publichnaya_biblioteka (06.04.2020). [In Russ.].

9. Irkutskaja publichnaja biblioteka [Irkutsk public library]. URL: https://www.irklib.ru/about/istoriya-biblioteki. (06.04.2020). [In Russ.].

10. Irkutskij akademicheskij teatr im. N. P. Okhlopkova [Irkutsk academic theater named after N. P. Okhlopkov]. URL: http://irkipedia.ru/node/42191/talk (10.04.2020). [In Russ.].

11. Istorija Kjakhtinskoj biblioteki [History of Kyakhta library] // Bibliotechnoje delo Respubliki Burjatii $\mathrm{v}$ licakh [Librarianship of the Republic of Buryatia in faces]. URL: http://baikal-center.ru/bibliodelo/?page_id=318 (10.04.2020). [In Russ.].

12. Mishakova O. E. Specifika organizacii muzejnoj praktiki v Zapadnom Zabaikalje v konce XIX - nachale XX veka [Specifics of arranging museum practice in the Western Transbaikalia at the end of the XIX- beginning of the XX century] // Vestnik Tomskogo gos. universiteta [Bulletin of Tomsk state university]. 2015. № 394. URL: https://cyberleninka.ru/article/n/spetsifika-organizatsiimuzeynoy-praktiki-v-zapadnom-zabaykalie-v-kontse-hih-nachale-hh-v 05.02.2020). [In Russ.].

13. Nerchinsk [Nerchinsk]. Chita, 2013. Pp. 285-292. URL: http://encycl.chita.ru/encycl/person/?id=8834 (c) The encyclopedia of Zabaikalia (06.04.2020). [In Russ.].

14. Oglezneva G. V. Muzej kak factor social'noj kommmunikacii vo vtoroj polovine XIX - nachale XX v. (na materialakh Irkutskoj gubernii) [Muse- 
um as a factor of social communication in the second part of the XIX-nachale XX v. (on the materials of the Irkutsk governorate) // Izvestija Irkutskogo gos. universiteta. Serija: Istorija [News of Irkutsk state university. Series: History]. 2012. № 2-2. URL: https://cyberleninka.ru/article/n/muzey-kak-faktor-sotsialnoykommunikatsii-vo-vtoroy-polovine-hih-nachale-hh-v-na-materialah-irkutskoygubernii (21.01.2020). [In Russ.].

15. Ocherki istorii Zabajkal'skogo kraja [Feature stories of the history of the Transbaikal region].V. 1-2. Chita, 2009. Pp.136-147. [In Russ.].

16. Pavlov K. A. Russkoje geograficheskoje obshchestvo: istorija i sovremennost' [The Russian geographical society: history and modernity] // Sovremennyje problemy servisa i turizma [Modern problems of service and tourism]. 2010. № 1. URL: https://cyberleninka.ru/article/n/russkoe-geograficheskoeobschestvo-istoriya-i-sovremennost (10.04.2020). [In Russ.].

17. Palikova T. V. Goroda Zabajkalja vtoroj poloviny XIX-nachale XX v. (social'noje, ekonomicheskoje, kul'turnoje razvitije [Towns of Transbaikalia of the second half of the XIX-beginning of the XX centuries (social, economic, cultural development)]. Ulan-Ude, 2010. Pp. 138-160. [In Russ.].

18. Flier A. Ya. Kulturnyj instrumentarij social'noj politiki [Cultural tools of social policy] // Kul'tura kul'tury [Culture of culture]. 2016. № 4 (12). URL: https://cyberleninka.ru/article/ n/kulturnyy-instrumentariy-sotsialnoy-politiki (21.03.2020). [In Russ.]. 
Бояк T. H.

Boyak T. N.

\section{СОЦИОЛОГИЯ МОЛОДЕЖИ В ПРОФЕССИОНАЛЬНОЙ} ПОДГОТОВКЕ КАДРОВ ДЛЯ ОТРАСЛИ КУЛЬТУРЫ

\section{SOCIOLOGY OF YOUTH IN THE PERSONNEL PROFESSIONAL TRAINING FOR THE SPHERE OF CULTURE}

В научной статье отмечается важность роли учреждений культуры в процессах социализации молодежи и необходимость вузов культуры осуществлять подготовку кадров, готовых к эффективной работе с молодежью, организации досуга группы на высоком современном уровне. Раскрывается, обосновывается значимость социологии молодежи в профессиональной подготовке кадров для отрасли культуры, способных компетентно решать задачи развития культуры общества, молодежи.

The article points out the importance of the role of the cultural establishments in the processes of youth socialization and necessity of higher educational institutions of culture to train the personnel ready for the effective work with the young people, organization of group leisure on the high modern level. The significance of youth sociology in the professional training of the personnel for the sphere of culture able to solve adequately the problems of the development of culture and youth is justified.

Ключевые слова: социология молодежи, молодежь, студенты, культура, общество, профессиональная подготовка кадров.

Keywords: sociology of youth, youth, students, culture, society, personnel professional training.

Молодежь выступает динамичной социально-демографической группой, выполняющей в жизни общества очень важную роль. От характера жизнедеятельности, ценностей молодого поколения напрямую зависят дальнейшие перспективы развития общества, темпы, направленность, результаты социальных преобразований.

Однако, характер проявления молодежи как субъекта социального развития во многом определяется условиями социализации, предлагаемыми социумом.

Важную роль в процессах личностного развития, социализации молодого поколения играют учреждения культуры. Работа с молодежью, организация досуга группы - одно из приоритетных направлений их деятельности. Качество, эффективность этой работы определяется уровнем профессионализма, компетентности сотрудников, умением системно, продуманно решать задачи, связанные с воспитанием, развитием личности, предоставлением широких возможностей для ее самореализации. Для этого профессиональным кадрам отрасли культуры необходимы: глубокие знания моло- 
дежной проблематики, методов ее исследования; умения применять знания на практике, научно обоснованно находить оптимальные пути решения актуальных задач в работе с молодежью посредством реализации целесообразных конкретных досуговых мероприятий, проектов. Важны знания возрастных, социально-психологических особенностей молодежного возраста для нахождения наиболее интересных для группы форм работы.

Сегодня заинтересовать молодое поколение в культурных услугах, предлагаемых учреждением - не простая задача. На содержание досуга современной молодежи оказывают влияние многие факторы: высокая значимость сети интернет, глобализация, индивидуализация, актуализация гедонистических ценностей в обществе, финансовые возможности молодых людей. Роль этих факторов неоднозначна. Поэтому досуговые потребности группы усложняются, имеют неоднозначный характер: с одной стороны, повышаются требования к организованному досугу, ожидания от него чего-то нового, способного удивить, с другой стороны, выраженной является ориентация на рекреативно-развлекательный и внеинституциональный досуг.

В связи с этим, важными задачами, которые предстоит решить учреждениям культуры, являются: повышение досуговой культуры молодого поколения, формирование его ориентаций на содержательный, развивающий, институциональный досуг, преодоление отношения к досугу только как средству получения удовольствий, развлечений. Решить такие задачи способны динамично развивающиеся учреждения культуры, компетентно применяющие в своей деятельности необходимые научные знания, опирающиеся на передовой практический опыт социокультурных институтов в области воспитания, организации досуга, внедряющие эффективные современные технологии работы с молодежью, которые отвечают требованиям времени, целям полноценного развития и самореализации личности. Тем более, данные анкетирования, проведенного автором среди студенческой молодежи Восточно-Сибирского государственного института культуры (ВСГИК) в 2016 году, показывают, что рассматриваемая группа осознает значимость ценностей личностного развития и самореализации. Для большинства респондентов в реализации смысла жизни очень важными являются: «реализовать себя как личность» - 76,3\%; «получить хорошее образование» - 69,2\%, «быть образованным, высоконравственным, интеллигентным человеком» $-62,6 \%$.

Досуг - важное слагаемое социально-психологического самочувствия физического, нравственного здоровья группы. Плохой досуг оказывает негативное влияние на процессы социализации молодежи, является одной из причин снижения уровня нравственной, гражданской культуры, распространения в ее среде девиации, преступности, актуализации проблемы выбывающей миграции.

Все вышеизложенное свидетельствует о важности миссии учреждений культуры в процессах формирования человеческого ресурса общества, перспективах социума, его культуры и одновременно о необходимости вузов культуры осуществлять подготовку кадров, способных к выполнению этой миссии на должном уровне, готовых к профессиональной, эффектив- 
ной работе с молодежью, организации ее досуга на высоком современном уровне.

Данное обстоятельство подчеркивает значимость дисциплины «Социология молодежи» в процессе профессиональной подготовки кадров для отрасли культуры.

Будучи одной из активно развивающихся отраслей социологической науки, социология молодежи позволяет осознать важность роли молодого поколения в развитии общества, изучить и осмыслить актуальные проблемы социально-демографической группы, понять их причины, необходимость и возможности (пути) решения, в том числе, средствами профессиональной, культурно-просветительской деятельности.

В рамках данной статьи мы освещаем роль социологии молодежи в подготовке бакалавров социально-культурной деятельности. Реализация профессиональной деятельности выпускников вуза, прошедших обучение по направлению «Социально-культурная деятельность», требует глубокого понимания связи тенденций, происходящих в современном обществе с процессами социализации и самореализации молодежи, умений на основе этого понимания разрабатывать и внедрять значимые, эффективные социальнокультурные проекты, программы. От глубины понимания бакалаврами социально-культурной деятельности широкого круга вопросов «обществомолодежь», степени развитости умений внедрять это понимание в решение задач профессиональной деятельности, а также от уровня их социальной активности, гражданской, нравственной культуры во многом зависят результаты деятельности учреждений культуры.

Вырабатываемые в процессе изучения дисциплины умения анализировать актуальные проблемы общества, молодежи, осмысливать пути их решения, являются важными составляющими формирования как профессиональных, так и личностных качеств у студентов.

Изучение дисциплины «Социология молодежи» способствует формированию у студентов знаний, адекватной ориентации в обществе, гражданских позиций, нравственных ценностей, необходимых для успешного решения задач профессиональной деятельности.

В процессе рассмотрения широкого круга вопросов во время занятий по социологии молодежи, обсуждения возможных путей решения тех или иных молодежных проблем средствами социально-культурной деятельности у студентов формируются навыки коллективной работы, качества толерантности, в том числе, относительно восприятия различных точек зрения, социальных, культурных различий друг друга. Подготовка к занятиям формирует также умения работать с литературой, эмпирической информацией, развивает способности к самоорганизации, самообразованию - важные компетенции, предусмотренные Федеральным государственным образовательным стандартом высшего образования по направлению подготовки «Социально-культурная деятельность» (уровень бакалавриата).

Учебный курс «Социология молодежи» призван обеспечить студентов необходимыми знаниями, умениями и навыками необходимыми для: а) глубокого анализа вопросов «молодежь - общество» (основанного на изучении 
литературы, статистики, материалов социологических исследований и др.), б) эффективной реализации потенциала дисциплины в решении профессиональных задач - применении результатов анализа / исследования в разработке социально-значимых проектов.

Так, например, в контексте освоения темы «Социология молодежи как отрасль социологического знания и учебная дисциплина» студенты изучают: предметное поле отрасли; теоретические подходы в определении понятия «молодежь», основные направления исследования молодежной проблематики; группообразующие признаки, характерные черты молодежи как социально-демографической группы; научные взгляды относительно определения возрастных границ молодежного возраста. Важным в контексте данной темы является изучение истории становления и развития социологии молодежи, содержания, проблематики, направленности исследований проблем молодежи в зарубежной и отечественной социологии. Студенты должны понимать роль молодежи в развитии современного общества, значение дисциплины в освоении профессии.

Тема «Социологический анализ процессов социализации молодежи» требует изучения концепций социализации молодежи. Приобретаются знания институтов, агентов, факторов социализации молодежи; осмысливаются содержание, характер процессов социализации группы в условиях современного российского общества, особенности социализации городской и сельской молодежи. Освоение темы определяет также необходимость изучения гражданских позиций, социальной активности молодежи, ее ориентаций на ценности здорового образа жизни и их формирования в процессе социализации. Важно понимание студентами и роли досуга в социализации личности, умение анализировать деятельность учреждений социально-культурной сферы по организации досуга молодого поколения.

Освоение темы «Духовно-нравственные ценности молодежи: диалектика преемственности поколений» предусматривает рассмотрение дефиниции «духовно-нравственные ценности»; факторов формирования, динамики духовно-нравственных ценностей российской молодежи (с начала 1990-х г . XX в. по настоящее время). В процессе освоения темы формируются умения студентов осмысливать особенности ценностей молодежи, определяющиеся жизнедеятельностью группы в условиях региона, города, села. Учет этих особенностей важен при разработке социокультурных проектов. В контексте темы обращается внимание и на изучение роли, места этнонациональных ценностей в процессе социализации, формировании духовнонравственной культуры молодежи; возможностей, потенциала и характера деятельности учреждений социально-культурной сферы по формированию ценностей социально-демографической группы.

Тема «Молодежь: образование, труд, занятость, миграция» включает: осмысление роли образования как ценности, социального института, процесса; анализ ориентаций молодежи на ценность образования. В рамках темы изучаются также вопросы профессионального самоопределения молодежи, обращается внимание на особенности, тенденции, актуальные проблемы 
профессионального самоопределения молодого поколения в современных условиях, факторы, оказывающие влияние на выбор профессии.

Поскольку студенты являются одной из прогрессивных групп молодежи, с которой общество связывает свои лучшие надежды на будущее, то в процессе изучения темы рассматриваются ценности, профессиональные ориентации, жизненные планы данной группы, а также направленность и содержание воспитательной работы со студенческой молодежью в современном вузе.

В рамках темы глубоко изучаются и вопросы, связанные трудовой самореализацией, занятостью, миграцией молодого поколения, вырабатываются умения осмысливать научную литературу с результатами социологических исследований, эмпирические, статистические данные.

Одна из тем курса «Молодежная семья» направлена на формирование понимания важных вопросов: любовь как ценность, мотив создания семьи; роль и место семьи в социализации, ориентациях молодежи. Необходимым является формирование у студентов умений анализировать семейно-брачные отношения молодежи в условиях современного российского общества; культурно-досуговые потребности молодежной семьи и возможности их удовлетворения средствами социально-культурной деятельности. В процессе изучения темы уделяется внимание также анализу процессов адаптации современной молодежи к семейной жизни, осмыслению задач, связанных с подготовкой группы к семейно-брачным отношениям, в том числе, посредством реализации социально-культурных проектов.

В рамках темы «Субкультура и девиантное поведение молодежи» студенты изучают особенности, причины образования феномена молодежной культуры; соотносят понятия «субкультура», «контркультура»; анализируют характер деятельности неформальных молодежных объединений; осмысливают проблемы девиации, преступности, экстремизма в молодежной культуре, а также роль учреждений социально-культурной сферы в предупреждении и профилактике этих проблем.

В процессе освоения темы изучаются и факторы формирования правового сознания, правовой культуры молодежи, обсуждаются возможности повышения уровня гражданско-правовой культуры группы посредством социально-культурной деятельности.

Тема «Основные аспекты государственной молодежной политики» включает изучение таких вопросов, как: роль государственной молодежной политики в создании благоприятных условий социализации, самореализации молодежи, решении проблем группы; основные направления, задачи, содержание государственной молодежной политики в России; молодежь и молодежные общественные объединения как объект и субъект государственной молодежной политики; деятельность учреждений социальнокультурной сферы по решению актуальных задач государственной молодежной политики.

В процессе освоения темы «Методология и методы социологического исследования проблем молодежи» формируется понимание основных слагаемых социологического исследования, его структуры, функций, видов, 
роли в познании актуальных проблем молодежи. Студенты изучают классификации основных методов сбора социологической информации, методику разработки инструментария и должны не только знать методы, методику социологического исследования, но и уметь применять их в профессиональной социально-культурной деятельности, разработке программ, проектов, направленных на решение задач, проблем, связанных с молодежью. Для этого предусмотрены практические задания по разработке программы и инструментария социологического исследования в контексте выбранных студентами тем.

Отметим, что освоение всех тем дисциплины «Социология молодежи» осуществляется в ходе лекционных, семинарских / практических занятий, самостоятельной работы студентов. Тексты сообщений, с которыми студенты выступают перед аудиторией на занятиях, основываются на анализе статистических данных, научной, учебной литературы, содержащей эмпирический, фактологический материал. Одним из слагаемых выступления является также предлагаемое студентом видение возможностей решения проблем, задач посредством профессиональной деятельности.

Процедура экзамена по дисциплине включает не только ответ по билету, но и подготовку, презентацию студентами на итоговом круглом столе «Актуальные проблемы социологии молодежи» своих исследовательских работ по одной из выбранных тем курса. Эти работы должны быть основаны на анализе научной литературы, эмпирических, статистических данных, обобщении результатов исследования, должны содержать рекомендации по решению выявленных в ходе исследования актуальных проблем, задач посредством социально-культурной деятельности.

Представляется, что это является важным относительно реализации практико-ориентированного обучения.

Освещение основных составляющих дисциплины «Социология молодежи», преподаваемой студентам, обучающимся по направлению подготовки «Социально-культурная деятельность», приведено с целью обоснования значимости этой дисциплины в профессиональной подготовке кадров для отрасти культуры, подтверждения ее практико-ориентированной направленности, значимости в формировании компетенций, необходимых работникам отрасли культуры в работе с молодежью.

Сегодня выстраивание эффективных моделей практикоориентированного обучения в подготовке кадров для отрасли культуры актуальная задача. От успеха решения данной задачи во многом зависят перспективы культуры общества, молодежи, как важнейшей социальнодемографической группы, в процессах социализации которой участвуют учреждения культуры.

В научной статье О.А. Подольского, В. А. Погожиной освещены результаты исследований, показывающие компетенции выпускников, молодых кадров, которые являются ключевыми при приеме на работу: «эксперты солидарны во мнении, что хотели бы видеть на рабочих местах в своих компаниях сотрудников, способных критически и аналитически мыслить, эффективно взаимодействовать с коллегами, качественно организовывать 
собственную рабочую деятельность и работу в команде, собирать и анализировать информацию из различных источников, справляться с повседневными рабочими проблемами и принимать взвешенные решения» [1, с. 101]. Развитию этих качеств, компетенций во многом способствует изучение социологии молодежи.

Все вышеизложенное свидетельствует о значимости социологии молодежи в профессиональной подготовке кадров для отрасли культуры.

\section{Примечания}

1. Подольский О. А., Погожина В. А. Ключевые компетенции выпускников и молодых специалистов при приеме на работу // Научное обозрение: гуманитарные исследования. 2016. № 1. С. 96-103.

\section{References}

1. Podolsky O. A., Pogozhina V. A. Kljuchevyje kompetencii vypusknikov i molodykh specialistov pri prijeme na rabotu [Graduates and young specialists' key competencies at applying for a job // Nauchnoje obozrenije : gumanitarnyje issledovanija [Scientific review: humanitarian research]. 2016. № 1. Pp. 96-103. [In Russ.]. 
DOI 10.31443/2541-8874-2020-3-15-53-60

УДК 378.016:008(571.54-25)

Амгаланова М. В., Назаров В. К.

Amgalanova M. V., Nazarov V. K.

СТАНОВЛЕНИЕ И СОВРЕМЕННОЕ СОСТОЯНИЕ КУЛЬТУРОЛОГИЧЕСКОГО ОБРАЗОВАНИЯ В РЕГИОНЕ

\section{DEVELOPMENT AND MODERN CONDITION OF THE REGIONAL CULTUROLOGICAL EDUCATION}

В статье рассмотрена история и современное состояние культурологического образования в Восточно-Сибирском государственном институте культуры, развитие культурологической науки. Авторы подробно останавливаются на анализе подготовки обучающихся по направлению «Культурология», роли культурологии как науки в учебном процессе.

The article considers the history and current condition of cultural education in East Siberian state Institute of culture, the development of cultural science. The authors give a detailed analysis of training the learners majoring in Culturology, the role of cultural science as a science in the educational process.

Ключевые слова: культурологическое образование, культурология как наука, бакалавриат, магистратура, аспирантура.

Keywords: cultural education, culturology as a science, bachelor's course of studies, master's course of studies, postgraduate studies.

Под культурологическим образованием понимается направление высшего образования по специальности «Культурология», а также общеобразовательный цикл дисциплин культурологического профиля для всех уровней образования, направленный на формирование мировоззренческих ориентиров, умение анализировать и оценивать явления культуры.

Культурология как наука имеет более широкий спектр определений. Остановимся на варианте, который предложил известный российский культуролог В.Л. Кургузов. Он пишет следующее: «По существу теоретический статус культурологии изначально укладывался в модель научной парадигмы - специфической области знания, интегрирующей методы и результаты других наук социально-гуманитарного профиля вокруг актуального проблемного поля - Культуры, включая морфологические единицы её многочисленных феноменов» [1, с. 15].

Во ВСГИК преподавание культурологии, под общепринятым в те времена названием «Марксистско-ленинская теория культуры», началось в 1975 году.

В 1985 году в стране началась перестройка. Наряду с большими просчетами и недостатками, были в этих реформах и позитивные результаты, многие из которых, правда, носили «косметический» характер. Так, в частности, от главной дисциплины культурологического цикла «Марксистско- 
ленинская теория культуры» ушло сочетание «марксистско-ленинская» и этот предмет стал называться «Теория и история культуры». Произошли положительные изменения и в содержании учебного курса, ушли порядком надоевшие сюжеты о К. Марксе, Ф. Энгельсе, В.И. Ленине, Н.К. Крупской, КПСС и т.д.

Главное, чем вошел 1991 год в анналы истории, это геополитический крах СССР и появление целой группы новых государств, включая Российскую Федерацию. В связи с тем, что Б.Н. Ельцин и его команда во главе с Е. Гайдаром, были ярыми западниками и активно поддерживались Западом во главе с США, в России началось распространение западной культуры, в первую очередь, массовой культуры, включая ее худшие образцы. Однако для дисциплин культурологического блока здесь произошли позитивные изменения, правда, в той же косметической манере, что и в начале перестройки. Историческая справедливость восторжествовала, и главному предмету культурологического цикла «Теория и история культуры» было возвращено название, которое впервые публично озвучил в своей судьбоносной для культурологии книге «Наука о культуре» известный американский культурантрополог Л.А. Уайт в 1949 году. Этим названием было слово «культурология».

В 1994 году в Российской Федерации появляются государственные образовательные стандарты (первого поколения), где культурология была включена в блок ГСЭ и в обязательном порядке читалась во всех вузах страны. Для культурологии наступил «золотой век» (правда, он оказался недолгим). В этом же году во ВСГИК создается первое в истории института структурное подразделение, одной из задач которого являлось развитие культурологического образования - Гуманитарно-культурологический центр.

Центр объединил все кафедры вуза, обеспечивающие блок предметов ГСЭ. Центр явился тем фундаментом, на котором был создан гуманитарнокультурологический факультет.

1995 год стал поворотным в истории вуза. Первое - ректором института избирается Р.И. Пшеничникова. Второе - институт культуры получает статус академии культуры и искусств. Эти события весьма благотворно повлияли на развитие культурологической науки и образования в академии. Особо следует отметить роль ректора ВСГАКИ, профессора Р.И. Пшеничниковой, которая проявляла неустанную заботу в деле развития науки о культуре.

В 1996 году было принято важнейшее решение об открытии на факультете культурного и природного достояния специальности «Культурология». Инициатива и лавры первенства в подготовке культурологов в академии культуры и искусств принадлежат В.В. Гапоненко, декану факультета КПД. Это был неординарный человек, ищущий ученый, талантливый педагог. Ее деятельность оставила яркий след в жизни академии, и не только в области культурологии. 
В 1997 году, буквально год спустя, во ВСГИК открывается аспирантура по культурологии по двум научным специальностям: 24.00.01 - теория и история культуры (культурология) и 24.00 .03 - музееведение, консервация и реставрация историко-культурных объектов (культурология). В течение долгого времени заведующей аспирантурой являлась кандидат исторических наук, доцент Т.Б. Батуева.

В 1998 году в академии происходит не очень заметное, но знаковое событие, явившееся важной вехой на пути культурологического процесса. Кафедра философии была переименована в кафедру философии, культурологии и политологии. Слово культурология стало звучать все чаще, а культурологическая проблематика стала предметом обсуждения на ректоратах, ученых советах и других мероприятиях вуза.

Следующим шагом был выход культурологических инициатив за пределы ВСГАКИ. В 1999 году ВСГАКИ совместно с Научноисследовательским институтом культурологии (Москва) и Министерством культуры РФ утверждает «Региональный образовательный культурологический центр», который функционирует на базе академии культуры и искусств. Возглавил Центр В.К. Назаров.

2000 год оказался переломным в развитии культурологического образования и науки во ВСГАКИ: при гуманитарно-культурологическом факультете была создана кафедра теории и истории культуры, возглавил которую В.К. Назаров. Наряду с ним, первый состав кафедры был представлен кандидатом культурологии, доцентом О.Н. Судаковой, кандидатом исторических наук, доцентом Т.Ф. Ляпкиной и совместителями: кандидатом философских наук, доцентом Е.Г. Хилтухиной и кандидатом культурологии, старшим преподавателем Л.В. Санжеевой. «Региональный образовательный культурологический центр» был прикреплен к кафедре теории и истории культуры, что способствовало активному взаимодействию кафедры с НИИ культурологии.

2001 год также явился определяющим, особенно в формировании культурологической науки в регионе. Во ВСГАКИ был открыт диссертационный совет К 210.002.01 по присуждению ученой степени кандидата культурологии по тем же специальностям, что были в аспирантуре: «Теория и история культуры», «Музееведение, консервация и реставрация историкокультурных объектов». Диссертационный совет возглавил доктор культурологии, профессор В.Л. Кургузов. За весь период своей деятельности диссертационный совет подготовил более 60 кандидатов культурологии, которые работают как у нас в стране, так и за рубежом.

С 2003 года кафедра стала осуществлять подготовку студентов по специальности «Культурология». В дальнейшем на кафедре, одной из первых в вузе, была создана законченная система многоуровневого культурологического образования: бакалавриат - специалистура - магистратура аспирантура - докторантура. 
В этом деле кафедра была первопроходцем в масштабе всей академии. Нельзя не отметить большую роль в создании этой системы кандидата исторических наук, доцента Т.Ф. Ляпкиной, ныне доктора культурологии, профессора и первого проректора ВСГАКИ, кандидата педагогических наук, доцента В.И. Солодухина, ныне доктора педагогических наук, профессора.

В 2006 году было создано Восточно-Сибирское региональное отделение российского культурологического общества (сегодня «Научнообразовательное культурологического общество Российской Федерации»), председателем которого был избран В.Л. Кургузов. В этом же году во ВСГАКИ создается факультет культурологии, в который вошли три кафедры: теории и истории культуры, теории и истории искусств, теории и истории народной художественной культуры. Первым деканом факультета был назначен В.К. Назаров.

В 2008 году в развитии культурологической науки во ВСГАКИ произошло очередное знаменательное событие: был открыт объединенный диссовет (ВСГАКИ-ВСГТУ) по защите диссертаций на соискание ученой степени доктора культурологии по тем же специальностям, что были ранее у диссертационного совета по защите кандидатских диссертаций. Председателем Совета также был утвержден В.Л. Кургузов.

В этом же году во ВСГАКИ были осуществлены масштабные структурные изменения, в частности, факультет культурологии был реорганизован в гуманитарно-культурологический факультет, а кафедра теории и истории культуры была переименована в кафедру культурологии.

В 2009 году при ВСГАКИ открылась докторантура по специальности «Теория и история культуры» (культурология), в 2011 году был зарегистрирован «Вестник Восточно-Сибирской государственной академии культуры и искусств», основным профилем которого является история, культурология, искусствоведение.

Также следует упомянуть, что при ГКФ 3 года успешно работал «Байкальский инновационный консалтинговый центр "Культура+"», возглавляемый кандидатом педагогических наук, доцентом С.Р. Баталовой. В процессе долгих лет трансформаций этот центр превратился в «Региональный образовательный культурологический центр».

Подводя итоги, можно отметить следующее, почти двадцать лет тому назад в 2001 году во ВСГАКИ была принята «Концепция культурологического образования». Фактически все поставленные в этой концепции цели и задачи были реализованы. Так, были созданы необходимые структурные подразделения, через которые функционировала вся инфраструктура культурологического образования и науки: кафедра культурологии, гуманитарно-культурологический факультет, диссовет по защите кандидатских и докторский диссертаций по культурологии, инновационный центр «Культура +». Сформирована законченная система подготовки кадров культурологов всех уровней: бакалавриат - специалистура - магистратура - аспирантура докторантура. 
Развитие кафедры происходило очень динамично. В 2009 году кафедра была переименована в кафедру культурологии, в 2013 - кафедру философии и культурологии, а в 2016 году была образована кафедра культурологии и искусствоведения, осуществляющая подготовку по направлениям «Культурология», «Теория и история искусств», «Изящные искусства».

За это время кафедрой было подготовлено более 130 культурологов. Многие из них работают по специальности, в учреждениях культуры и образования Восточной Сибири. Особенно приятен тот факт, что среди выпускников есть те, кто продолжает заниматься наукой, учатся в магистратуре и аспирантуре по своей специальности, а двое выпускников стали кандидатами культурологии.

В настоящее время это направление образовательной деятельности вуза реализуется на кафедре культурологии и искусствоведения и представлено развитой многоуровневой системой и двумя направлениями. Вопервых, изучение студентами всех направлений подготовки ряда культурологических дисциплин, обеспечивающих формирование общекультурных (или согласно новому стандарту универсальных) и общепрофессиональных компетенций. И, во-вторых, подготовка кадров по направлению «Культурология».

Первое направление - общевузовский блок культурологических дисциплин в условиях перехода на ФГОС $3++$ состоит из следующих курсов:

- «Культурология» - теоретический курс, который направлен на овладение основополагающим понятийно-категориальным аппаратом будущей профессиональной деятельности, формирование целостного представления о мировой, национальной, этнической культуре, культуре личности и закономерностях развития современной культуры;

- «Основы государственной культурной политики» - практикоориентированный курс, дающий знание целей, задач, направлений государственной культурной политики в РФ и форм их реализации на региональном и муниципальном уровнях;

- «Культура и искусство Сибири и Дальнего Востока» - курс регионального компонента, который предлагается на выбор руководителям образовательных программ и направлен на знакомство с духовным и материальным культурным наследием региона.

В образовательную программу магистрантов введена дисциплина «Межкультурное взаимодействие».

Данный блок дисциплин, включенный в учебные планы 2019 года набора, наиболее полно отражает принцип культурологического образования, а именно интеграцию теории и практики, системность и направленность на развитие социально-ценностных качеств личности. Особенно внимание педагогами при чтении данных курсов уделяется культурологическому подходу, который в нашем вузе определяется как базовый в формировании личностно-ориентированного образования. 
Второе направление реализации культурологического образования в нашем вузе - это подготовка кадров по направлению «Культурология», открытого еще в 1996 году. Кафедра - одна из немногих в Институте, которая реализует подготовку по трем уровням образования: бакалавриат - магистратура - аспирантура. Именно поэтому в структуре культурологического образования особенное внимание уделяется научно-исследовательской деятельности, что выражается в значимых для формирования имиджа Института достижениях студентов и аспирантов. Это:

- лауреаты государственной премии в области поддержки талантливой молодежи Республики Бурятия;

- стипендиаты «Персональной стипендии им. Д.С. Лихачева для студентов вузов РФ»;

- стипендиаты республиканского конкурса стипендий студентов и аспирантов образовательных организаций высшего образования и научных организаций в области культуры и искусства;

- призеры Международной интернет-олимпиады по философии, культурологии, правоведения, истории;

- призеры Первого Всероссийского студенческого конкурса научных и творческих работ;

- призеры Всероссийской открытой олимпиады научных работ «Культурное пространство России: инновации и традиции»;

- призеры Республиканских олимпиад по философии, английскому языку, истории, правоведению.

Ежегодно студенты и аспиранты принимают активное участие в различных международных, российских, внутривузовских научных конференциях, среди которых наиболее значимыми являются Международные научно-практические конференции «Культурное пространство Восточной Сибири и Монголии», организовывается и проводится кафедрой (Улан-Удэ, 2015, 2017, 2019), «Система ценностей современного общества» (Новосибирск, 2016), XXXVII «Молодежный научный форум: Общественные и экономические науки» (Москва, 2016), «Байкальский встречи» (Улан-Удэ, 2016, 2018), «Актуальные проблемы литературоведения, языкознания и культуры Восточной Сибири, Монголии и Китая» (Улан-Удэ, 2018, 2019), «Художественные традиции Сибири» (Красноярск, 2018), Всероссийский молодёжный форум «Таврида» (Крым, 2016, 2019). В 2015, 2016 годах студентами был выигран Открытый грантовый конкурс благотворительного фонда М. Прохорова «Академическая мобильность» с целью сбора материала в г. СанктПетербург и г. Харбин (Китай). За последние 5 лет обучающимися кафедры была опубликована 81 статья, в том числе 5 статей ВАК. За всеми этими достижениями студентов без сомнения стоит профессионализм педагогов, которые с ними работают.

В течение многих лет кафедра разрабатывает научную тему: «Культурное пространство Восточной Сибири: становление, современной состояние и тенденции развития». Целью научной темы является исследование 
фундаментальных и прикладных аспектов культурного пространства Восточной Сибири: изучение, проблематизация и формирование перспективы развития культуры и искусства региона.

Еще одним важным компонентом в структуре культурологического знания является прохождение практики. В соответствии с заключенными договорами у обучающихся имеется возможность получить навыки владения будущей профессии в Министерстве культуры РБ, научных заведениях, образовательных учреждениях и т.п. По профилю: «Культура Китая» осуществляется выездная практика. Имеется заказ на проведение разного рода мероприятий в школах. В целом основными сферами профессиональной деятельности культурологов - выпускников Института - являются:

- управленческая деятельность в органах федерального, регионального, муниципального государственного управления;

- преподавательская деятельность в образовательных учреждениях профессионального и дополнительного образования;

- научно-исследовательская деятельность;

- работа культурно-просветительных учреждениях (музеи, библиотеки, культурные центры, досуговые центры и др.);

- в сфере туризма;

- СМИ;

- экспериментальная деятельность в организациях и учреждениях по международным культурным связям, межрегиональному сотрудничеству и межнациональным отношениям.

Анализ трудоустройства выпускников за последние 5 лет показал, что по специальности работают около 40\% (культурно-досуговые центры, СОШ и школы искусств, музеи, библиотеки, туристические агентства, муниципальные отделы культуры); примерно 15\% выпускников продолжают учебу в магистратуре и аспирантуре; около 45\% занимаются коммерческой деятельностью либо трудоустроены не по специальности.

Что касается перспективы развития культурологического образования в нашем вузе, то они видятся в первую очередь в наличии (предоставлении) бюджетных мест, которых, к сожалению, в вузах культуры, подведомственных Министерству культуры РФ, в последние два года не было выделено. Поэтому особенное внимание стоит обратить на уровни магистратура и аспирантура. Обучающимися здесь являются не только студенты направления культурологии, но и других специальностей, вузов и регионов. Окончившие магистратуру, а также преподаватели, не имеющие ученой степени, могут продолжить обучение в аспирантуре, защититься и работать в вузе с более высокой квалификацией.

Подводя итог сказанному, отметим, что культурологическое образование в ФГБОУ ВО ВСГИК имеет хорошие перспективы в плане реализации учебных дисциплин, в подготовке кадров направления «Культурология», организации практик, в том числе и выездных, научно-исследовательской деятельности. Все это является площадками для взаимодействия не только 
внутри нашего Института, но и профессионального культурологического сообщества.

\section{Примечания}

1. Культурологическое образование и наука в Восточной Сибири: актуальные проблемы и перспективы : материалы регион. круглого стола, посвящ. 10-летию каф. культурологии и 10-летию Диссертационного совета ДМ 210.002.01 - Теория и история культуры (культурология) (Улан-Удэ, 20 мая 2011 г.). Улан-Удэ : Изд.-полигр. комплекс ВСГАКИ, 2011. 238 с.

\section{References}

1. Kul'turologicheskoje obrazovanije i nauka v Vostochnoj Sibiri: aktual'nyje problemy i perspektivy : materialy region. kruglogo stola, posvjashch. 10-letiju kaf. kul'turologii i 10-letiju Dissertacionnogo soveta DM 210.002.01 Teorija i istorija kul'tury (kul'turologija) (Ulan-Ude, 20 maja 2011g.). Ulan-Ude, 2011. 238 p. [In Russ.]. 
DOI 10.31443/2541-8874-2020-3-15-61-72

УДК 902/904(571.54)

Дикий Я. В.

Dikiy Ya. $V$.

\section{АРХЕОЛОГИЧЕСКИЕ КОЛЛЕКЦИИ В СОСТАВЕ ИСТОРИКО-КУЛЬТУРНОГО НАСЛЕДИЯ БУРЯТИИ: ПРОБЛЕМА ДЕФИНИЦИЙ ${ }^{1}$}

\section{ARCHAEOLOGICAL COLLECTIONS WITHIN THE HISTORICAL AND CULTURAL HERITAGE OF BURYATIA: THE PROBLEM OF DEFINITIONS}

В статье исследуется проблематика определения «археологическая коллекция». В настоящее время в источниковедении, археологии и музееведении нет единого подхода к этому термину. Приведены примеры использования в работах ученых дефиниции «археологическая коллекция» в разных контекстах. В законодательных и нормативно-правовых актах также нет единого определения этого термина. Отсутствие общего понимания дефиниции приводит к ряду трудностей при анализе археологических коллекций. Разработка единого подхода позволит повысить сохранность этой важной части культурного наследия Бурятии.

В связи с этим основной задачей статьи стало предложение общего определения «археологическая коллекция» с учетом специфики источниковедения, археологии и музееведения. Археологическая коллекция рассматривается автором как комплексный исторический источник, состоящий из трех основных частей: вещественной (археологические находки), письменной (научные отчеты, полевые дневники, научно-делопроизводственные и учетные документы) и визуальной (фотографии, чертежи, рисунки).

The article explores the problem of defining "the archaeological collection". At present, there is no unified approach to this term in source studies, archaeology and museum studies. The examples of the definition "archaeological collection" use in different contexts are given in the works of the scientists. There is also not any unified definition of this term in legislative and regulatory acts. The lack of common understanding of the definition "archaeological collection" leads to the number of difficulties in the analysis. The unified approach development will allow to preserve this important part of the cultural heritage of Buryatia.

In this regard, the main task of the article is to suggest a general definition of the "archaeological collection" taking into account the specifics of source stud-

\footnotetext{
${ }^{1}$ Исследование выполнено при финансовой поддержке гранта Правительства Российской Федерации № 14.W03.31.2016 «Динамика народов и империй в истории Внутренней Азии»
} 
ies, archaeology and museology. The author considers the archaeological collection as a complex historical source consisting of three main parts: material (archaeological findings), written (scientific reports, field diaries, scientific and financial records) and visual (photographs, drawings, drawings).

Ключевые слова: источниковедение, археология, музееведение, археологическая коллекция, археологическое собрание, Бурятия.

Keywords: source studies, archaeology, museology, archaeological collection, archaeological collection, Buryatia.

Археологические коллекции - составная часть историко-культурного наследия; это важный источник исторической памяти любого народа. Сегодня на государственной охране в Бурятии находятся более 700 объектов археологического наследия, и с каждым годом их перечень увеличивается. Наша общая задача - сохранить и передать будущим поколениям богатое и самобытное историческое наследие республики. Для этого очень важно понимать, что именно хранится, как вести учет, каким образом включать в исторические исследования и т.д. Все эти процессы требуют точного понимания дефиниций сохраняемых объектов.

Для того, чтобы дать определение «археологической коллекции» и выявить особенности археологических коллекций, прежде всего необходимо понять специфику исторического источника в археологии.

Археологическая коллекция в нашем исследовании рассматривается в источниковедческом контексте, что вызывает необходимость учитывать так называемый эффект двойной субъективации, когда работа с любым историческим источником является взаимодействием двух культур - создателя и исследователя. Более того, археологическая коллекция является и объектом двух культур: прошлого и современности.

Рассмотрим «триаду» исторический источник - археологический источник - археологическая коллекция. В современном источниковедении выработано три подхода к историческому источнику: культурологический - в широком смысле, как все созданное людьми (О.М. Медушевская, В.А. Муравьев, И.Н. Данилевский); расширительный - представители этого подхода исторический источник вывели термин за рамки только источников «исторического происхождения» (С.О. Шмидт, С.М. Каштанов, В.В. Кабанов); информационный - исторический источник, по мнению сторонников данного подхода, выполняют функцию накопления, хранения и передачи социальной информации о прошедшей действительности (И.Д. Ковальченко, А.Г. Голиков, Т.А. Круглова) [20, с. 7-9].

Исторический источник в данном исследовании понимается с позиций расширительного подхода. При этом подходе исторический источник «это все, откуда можно получить информацию о развитии человеческого общества... все то, что может источать информацию, полезную для историка, а не только результаты целенаправленной человеческой деятельности, хотя именно источники исторического происхождения (т.е. памятники материальной и духовной культуры) составляют основной массив исторических источников. Источники - это и окружающая естественно- 
географическая среда, и физико-биопсихические свойства самого человека, во многом предопределяющие и объясняющие деятельность и отдельных индивидуумов, и общества в целом» [20, с. 7].

Обратимся теперь к такому фундаментальному понятию археологии, как «археологический источник» [12, с. 4]. В отечественной науке этот термин не имеет общепринятого понимания и подхода.

Так, в Советской исторической энциклопедии, археология - «отрасль исторической науки, изучающая первобытные, древние и средневековые памятники и реконструирующая по ним прошлое человеческого общества. На последнем этапе исследования археолог выступает как историк» [23, с. 824]. Вещественные памятники (к которым относятся и памятники археологические), в свою очередь являются историческими источниками $[23$, с. 591].

Однако ряд ученых считали, что ископаемые объекты, которые относятся по происхождению к археологическим источникам, не должны входить в блок исторических источников. Более того, «прямо никакой археологический источник не способен дать ответы на вопросы историка» [5, с. 41].

По мнению Л.С. Клейна, «понятием «археологические источники» характеризуется главное средство обеспечения археологических исследований базой фактов» [12, с. 5]. В то же время он считает, что «археологические источники - и не безоговорочно исторические, и не только исторические» $[12$, c. 25$]$. Такое понимание «археологического источника» возможно в том случае, если «археология играет роль источниковедческой дисциплины по отношению к другим наукам» [13, с. 315].

Иного мнения по отношению к термину «археологический источник» придерживаются И.С. Каменецкий, Б.И. Маршак и Я.А. Шер [11]. По их мнению, «археологический источник, даже не совсем достоверный, вне науки невозможен» [11, с. 162]. Более того, археологический источник, как любой источник научной информации, «должен позволять обращаться к нему многократно, если возникают новые вопросы или новые исследовательские подходы» [11, с. 162]. При этом авторы понимают, что повторное обращение к археологическому памятнику невозможно по причине его уничтожения в ходе раскопок. По этой причине источником научной информации становится не сам памятник, а «наблюдения и факты», которые выражаются в отчетах о раскопках и в другой полевой документации. Документация эта ведется при раскопках, а также в ходе камеральных, лабораторных работ и иных анализов и определений (антропологических, палеозоологических, палинологических и др.) [11, с. 162-163]. При таком подходе археологическим источником становится не столько сам археологический памятник, сколько «комплекс тех документов, которые формируются исследователем при изучении памятника» [11, с. 162].

Термин «археологическая коллекция» широко используется в научных статьях, монографиях и диссертациях ученых. Между тем «археологическая коллекция» как особая единица учета не отражена ни в одном из законодательных или нормативно-правовых документах РФ. 
В музееведении «археологическая коллекция» трактуется как «систематическое собрание предметов археологии» [19]. Такое определение мало чем отличается от понимания «этнографической коллекции - систематизированное собрание предметов... этноса или этнической группы» или «художественной коллекции - собрание предметов изобразительного искусства» [19]. При таком подходе не учитываются специфические особенности.

В последнее десятилетие выходят научные работы, в которых говорится об «археологической коллекции» как важном информационном источнике, который состоит из нескольких частей. Коллекция в подобных работах рассматривается во всей своей целостности без отрыва от научной документации [3; 14; 10;2].

Археологи Бурятии используют этот термин в разном контексте. Так, Л.Г. Ивашина констатировала: «При кратком обзоре собранных коллекций автор (прим. А.П. Мостиц) классифицировал имевшийся материал по типам орудий» [9, с. 10]. Или «в районе Троицкосавска, на Гусином озере, и в Агинской степи в Восточном Забайкалье П.С. Михно собраны археологические коллекции, ныне хранящиеся в Кяхтинском краеведческом музее» [9, с. $11]$.

А.В. Давыдова, описывая имеющуюся источниковую базу своего исследования, писала: «Сохранившиеся материалы раскопок 1949-1950 гг. хранятся в двух местах: часть керамики была сдана в Улан-Удэнский краеведческий музей, незначительная часть археологической коллекции хранится в Государственном Эрмитаже» [6, с. 8].

Б.Б. Дашибалов в своей работе также использует термин «археологическая коллекция» и его синонимы: «Археологическая коллекция, собранная М.П. Овчинниковым, это, прежде всего, предметы подъемных сборов» [7, с. 53]. Или «коллекция Б.Э. Петри по «Курумчинским кузнецам» хранится в Музее антропологии и этнографии (г. Санкт-Петербург) и Иркутском краеведческом музее» [7, с. 58]. Еще одним примером использования стало следующее предложение: «коллекция Шохтоя неоднородна и является смешанной» [7, с. 58].

В.И. Ташак, используя этот термин, отмечает, что коллекции служили основным источником: «Многочисленные, но разнородные и разрозненные коллекции с различных местонахождений каменного века долгое время служили основным источником для построения периодизационных схем и формирования общей картины древнейшего прошлого Забайкалья» [24, с. 3]. Далее контекст использования иной: «К 90-м гг. к палеолитическим предположительно можно было отнести небольшое количество артефактов из археологических коллекций, собранных в окрестностях Усть-Кяхты» [24, c. 89].

В коллективной работе «Раскопки жилища монгольского времени на нур-тухумском археологическом комплексе» отмечается, «что необходимы дальнейшие исследования на памятнике для получения данных об архитектурных и планиграфических особенностях поселения, определению взаимных связей между его структурными элементами и новой археологической коллекции для корреляции с имеющимися материалами погребальных па- 
мятников, что позволит дать более четкую интерпретацию памятника в историко-хронологическом контексте» [1, с. 84].

А.И. Симухин, используя термин «археологическая коллекция», отмечает, что «источниковую базу составили археологические коллекции предметов из цветного металла, хранящиеся в Музее БНЦ СО РАН, Музее истории Бурятии им. М.Н. Хангалова, Кяхтинском краеведческом музее им. В.А. Обручева» [21, с. 4].

Как отмечалось выше, кроме непосредственно термина «археологическая коллекция», исследователями часто используются синонимы этого термина «коллекция», «коллекция артефактов».

Так, Л.В. Лбова использует несколько синонимов термина «археологическая коллекция»: «Коллекция артефактов, хранящаяся в фондах ИАиЭ СО РАН (1451 ед.), в лаборатории археологии ИГУ (16 ед.), в лаборатории археологии ИМБиТ СО РАН (21 ед.), в целом насчитывает 1488 предметов» $[15$, c. 66]. Или: «Орудийный набор коллекции Варвариной горы представлен 327-ю экземплярами (21\% артефактов), из них 24 экз. так называемые атипичные предметы (галечные «терки»)» [15, с. 69].

В другой работе Л.В. Лбовой синонимы также встречаются: «При подготовке монографии использовались материалы и коллекции из раскопок Фофановского могильника 1948, 1950 гг. (фонды Музея истории Бурятии)» [16, с. 5]. В другой части работы: «Такие ононские поселения, как Чиндант и Арын-Жалга, а также монгольское поселение Тамцак-Булак, дали выразительные коллекции изделий» [16, с. 82]. Также термин «коллекция» используется для обозначения отдельного типа артефактов: «В состав коллекции каменного инвентаря входят: нуклеусы, микропластины, проколки, резчики, двулезвийные ножи, скребки, пилки, отщепы и скребла» [16, с. 131]. Или: «Коллекция украшений включает бусины и 2 подвески из клыков марала, пришлифованные ниже отверстий» [16, с. 104].

Н.В. Цыденова также отмечает: «В итоге сборов подъемного материала была сформирована коллекция артефактов» [25, с. 124].

Таким образом, понимание термина «археологическая коллекция» или его синонимов зачастую сводятся к систематическому собранию археологических предметов.

Надо отметить, что отсутствие единого понимания «археологической коллекции» вызывает трудности при работе с ними. Так, например, в разных учреждениях Бурятии в основу деления археологического фонда на отдельные археологические коллекций положены разные принципы. В Этнографическом музее народов Забайкалья весь фонд археологии входит в одну археологическую коллекцию. По сути, эта коллекция Хунну, которая была передана А.В. Давыдовой в 1977 г. с археологического памятника «Иволгинское городище». Причина выбора такого принципа деления связана с небольшим размером археологического фонда музея (всего 99 предметов).

В Кяхтинском краеведческом музее им. В.А. Обручева принцип деления коллекций иной. Этот первый краеведческий музей на территории Бурятии также стал первым местом хранения археологических коллекций. Исторически сложилось, что все коллекции этого музея авторские, т.е. основ- 
ной принцип деления - это принадлежность к автору археологических работ. Так, в дореволюционный период были сформированы коллекции Ю.Д. Талько-Грынцевича, А.П. Мостица, П.С. Михно, Я.С. Смолева. В советские годы продолжилось формирование коллекции П.С. Михно, а также были сформированы новые: С.А. Успенского, А.П. Окладникова, Р.Ф. Тугутова, А.В. Давыдовой, П.Б. Коновалова, С.С. Миняева, А.Д. Цыбиктарова.

В Национальном музее Республики Бурятия представлен третий принцип, по которому выделяют отдельные археологические коллекции. В его основу положена принадлежность к археологическому памятнику. Например, в Национальном музее РБ имеются коллекции: «Хотык», «Варварина гора», «Мухор-Тала», «Нянги» и т.д. всего 32 коллекции. При этом важно подчеркнуть, что несколько подобных коллекций объединены в группу коллекций, согласно принципу принадлежности к исторической эпохе: «Палеолит», «Неолит», «Хунну» и т.д.

В Музее Бурятского научного центра сектор археологии объединен в единое собрание археологических предметов.

В Институте монголоведения, буддологии и тибетологии СО РАН деление коллекций происходит по принадлежности материала к археологическому памятнику. Исключением является краниологическая коллекция. Крупными коллекциями являются «Ильмовая падь», «Енхор», «Сутайская феодальная усадьба», «Иволгинское городище», «Удинский острог» и др. Всего - 37 коллекций.

Еще один принцип деления фондов на отдельные археологические коллекции - это типологический принцип, т.е. объединение предметов в коллекции на основе типологического родства отобранных предметов. При этом предметы могут относиться к разным культурам и эпохам. Данный принцип деления условный и встречается в научных публикациях, а объединение это необходимо для удобства исследования, вошедших в коллекцию предметов [22; 18$]$.

Таким образом, в Бурятии выявлено пять основных принципов деления фондов на археологические коллекции: авторский принцип; локальный (принадлежность к археологическому объекту); хронологический (отношение к исторической эпохи); принадлежность к археологической культуре; типологический (основан на типологическом родстве предметов).

Определенные трудности вызывают собрания так называемого «подъемного материала» - предметы археологии, которые получены в ходе разведочных работ и обследований археологических объектов и сборов. Кроме того, в учреждениях хранится значительное количество материала, который не поставлен на учет и не принят на хранение. Например, в Кяхтинском краеведческом музее имеется коллекция А.Д. Цыбиктарова, которая не учтена в музейной документации (Книга поступлений, коллекционная опись, инвентарная книга). Несвоевременная постановка на учет археологической коллекции может привести к потере важной информации об обнаруженных предметах, времени и месте обнаружения, а также к потере артефактов. 
Также с определенными трудностями мы столкнулись при работе с материалами разновременных археологических памятников. Возможно ли объединять археологические предметы с подобного рода памятников в одну коллекцию? Или группировать их по принадлежности к исторической эпохе или по отношению к автору? Единства в этом вопросе также нет. Например, коллекция «Кибалино» (ИМБТ СО РАН) включает разновременные материалы раскопок 1977 г. (неолит - средневековье). В ее составе - около 14 тыс. предметов, среди них фрагменты неолитической керамики и остатки каменной индустрии, и антропологический материал, относящийся к средневековью.

На этом фоне понимание дефиниции естественнонаучных коллекций, в частности геологических, более регламентировано и разработано.

Сравним методические рекомендации по формированию, учету, хранению и использованию геологических коллекций [8] и пособие по учету и хранению археологических коллекций [17; 4]. Прежде всего, у геологов четко выработано понимание «геологической коллекции» как отдельной учетной единицы. Отдельный предмет является лишь составной частью коллекции. В то время как в рекомендациях по работе с археологическими коллекциями все сводится к работе с отдельным «археологическим предметом» $[4$, c. 10-16]. Часто археологический предмет уравнивается с археологической коллекцией, и употребляется в следующей форме: «археологический предмет/коллекция» [4, с. 23-24].

Кроме того, в составе «геологической коллекции» обязательным является наличие различной документации, баз данных, а также научных работ, написанных на основе анализа этой коллекции [8, с. 28]. Для археологических коллекций с одной стороны признается необходимость включения документации в состав коллекции [4, с. 13]. С другой, «археологическая коллекция» сводится к совокупности предметов, происходящих с одного археологического памятника, и не учитывает наличие документации [4, с. 11-13]. Более того, не дается никаких рекомендаций по работе с этими документами, состав которых также точно не определен.

В ходе исследования нами был выработан подход к «археологической коллекции» как к комплексному историческому источнику. Комплексность его заключается в том, что в коллекцию обязательно должны входить три типа исторических источников: вещественные - весь объем археологического материала, полученного в ходе полевых работ; письменные - научная документация (дневники, отчеты, научная публикации), сопроводительная документация (описи, акты); визуальные - фотографии, чертежи и рисунки. Письменная и визуальная части часто (но не всегда) являются единым документальным массивом (научные отчеты, публикации), а также имеют ряд научных требований. Они могут быть объединены в группу «научная документация».

Важно отметить, что вещественная часть и научная документация должны быть равноправными частями археологической коллекции. Изучение только вещественной части, в отрыве от научной документации, приведет к тому, что станет вероятна утрата контекста обнаружения, т.е. собрание 
предметов становится большой группой единиц хранения без привязки к историческому контексту. Исследуя только научную документацию, можно упустить особенности предметов или группы предметов, так как не весь объем обнаруженного материала подробно описывается автором раскопок.

Кроме того, комплексный подход к археологической коллекции позволяет получить информацию не только о памятниках, эпохах и культурах, но и о развитии археологии как науки в регионе. Появляется возможность проследить основные этапы становления, подъемов и спадов археологических исследований, расширения исследовательского поля. Показательным в этом отношении является период 90-х гг. ХХ в. В это время отмечается спад археологических исследований, что отразилось и на объемах археологических коллекций, сформированных в этот период. С другой стороны, в 80-х гг. XX в., когда наблюдается рост числа исследований, расширение исследовательского интереса, ускоряются и темпы формирования новых и доукомплектование уже имеющихся археологических коллекций.

Однако, чтобы такой подход работал, археологическую коллекцию необходимо воспринимать как самостоятельную единицу хранения, в состав которой входит вещественная, письменная и визуальная части. Таким образом, археологическую коллекцию правомерно рассматривать как комплексный исторический источник.

Отличительной чертой археологической коллекции является то, что наибольший объем научной информации возможно получить лишь при использовании разных типов источников: вещественные, письменные и визуальные. При этом вещественная часть понимается в максимально широком значении, т.е. весь археологический материал. В свою очередь этот материал должен быть тщательно зафиксирован на других носителях информации (письменных и визуальных). Письменная и визуальная части составляют важную и необходимую составляющую коллекции. Их наличие позволяет получить разнообразную информацию: об археологическом объекте, о ходе работ, об используемых методах, о контексте обнаружения отдельных находок и их групп, о предварительной интерпретации обнаруженного материала и др. Иными словами, с помощью полевой и научной документации появляется возможность повторного обращения к разрушенному в ходе полевых археологических работ памятнику. Кроме того, письменные и визуальные материалы позволяют проследить этапы развития археологии как науки.

Итак, лишь при комплексном использовании всех составляющих археологических коллекций можно получить максимум информации об этом сегменте историко-культурного наследия Бурятии, а также репрезентативные данные для реконструкции древней и средневековой истории региона.

\section{Примечания}

1. Раскопки жилища на Нур-Тухумском археологическом комплексе / Б. А. Базаров, Д. А. Миягашев, Н. В. Именохоев, А. М. Клементьев // Поволжская археология. 2019. № 4 (26). С. 84-97. 
2. Баранов В. С. Целостность археологических коллекций в музейном хранении. Эффект «распредмечивания» // Археология Евразийских степей. 2019. № 5. C. 66-75.

3. Бердникова Н. Е. Археологические объекты, коллекции и проблемы хранения // Известия Иркутского гос. ун-та. Серия: Геоархеология. Этнология. Антропология. 2014. Т. 10. С. 94-109.

4. Воробьева С. Л. Комплектование, учет, хранение и научное описание археологических коллекций в музеях: правовые аспекты и практический опыт : науч.-метод. пособие. Уфа : Национальный музей Республики Башкортостан, 2019. $160 \mathrm{c}$.

5. Григорьев Г. П. О предмете археологии // Тезисы докладов сессии, посвященной итогам полевых археологических исследований 1972 г. в СССР. Ташкент, 1972. С. 41-48.

6. Давыдова А. В. Иволгинский комплекс (городище и могильник) памятник хунну в Забайкалье. Л. : Изд-во ЛГУ, 1985. 111 с.

7. Дашибалов Б. Б. Очерки по древней и средневековой истории монголов и бурят. Улан-Удэ : Респ. тип., 2002. $81 \mathrm{c.}$

8. Методические рекомендации по формированию, учету, хранению и использованию геологических коллекций / И. М. Задорожный, А. А. Иванов, Л. Р. Колбанцев, А. М. Карпунин. М. : ВСЕГЕИ, 2005. 54 с.

9. Ивашина Л. Г. Неолит и энеолит лесостепной зоны Бурятии. Новосибирск : Наука, 1979. 157 с.

10. Казанцева О. А. Делить нельзя изучать (целостность археологической коллекции: возможности и трудности научного исследования) // Археология Евразийских степей. 2019. № 5. С. 57-66.

11. Каменицкий И. С., Маршак Б. И., Шер Я. А. Анализ Археологического источника: возможности формализованного подхода. Изд. 2-е. М. : ИА РАН, 2013. $182 \mathrm{c.}$

12. Клейн Л. С. Археологические источники : учеб. пособие. Л. : Издво Ленинград. ун-та, 1978. 119 с.

13. Колпаков Е. М. Почему «археологические источники»? // Археологические источники / Л. С. Клейн. Изд. 2-е, доп. СПб. : Фарн, 1995. С. $302-$ 327.

14. Конончук К. В. Археологическая коллекция музея-заповедника «Томская Писаница» как источник по древнейшей истории юга Нижнего Притомья : препринт // Историко-культурный и природный заповедник «Томская писаница». Ф. 5. Оп. 1. Д. 28. 13 с.

15. Лбова Л. В. Палеолит северной зоны Западного Забайкалья. Улан-Удэ : Изд-во БНЦ СО РАН, 2000. 240 с.

16. Лбова Л. В., Жамбалтарова Е. Д., Конев В. П. Погребальные комплексы неолита-раннего бронзового века Забайкалья (формирование архетипов первобытной культуры). Новосибирск : Изд-во Ин-та археологии и этнографии СО РАН, 2008. 248 с.

17. Методика обработки коллекций : учеб. пособие / А. П. Бородовский, Л. В. Лбова, В. П. Мыльников, Л. Н. Мыльникова, Т. И. Нохрина, И. В. Сальникова. Новосибирск, 2013. 391 с. 
18. Мясников В. Ю., Ярославцева Л. Г. Три средневековых клинка из коллекции национального музея Республики Бурятия // Теория и практика археологических исследований. 2017. № 3 (19). С. 57-68.

19. Российская музейная энциклопедия. URL: http://museum.ru/rme/rme.htm (дата обращения: 17.05.2020).

20. Русина Ю. А. Источниковедение новейшей истории России : учеб. пособие. Екатеринбург : Изд-во Урал. ун-та, 2015. 236 с.

21. Симухиин А. И. Технологические традиции в производстве изделий из цветного металла в Забайкалье (II тыс. до н. э. - XIX в.) : автореф. дис. ... канд. ист. наук. Улан-Удэ, 2006.

22. Симухин А. И. Коллекция бронзовых ножей музея Бурятского научного центра СО РАН (II-I тыс. до н. э.) // Древние культуры Монголии и Байкальской Сибири : материалы 4 междунар. науч. конф. (Чита, 13-19 сент. 2013 г.) : в 2 ч. Ч. 2. Чита, 2013. С. 277-287.

23. Советская историческая энциклопедия / гл. ред. Е. М. Жуков. М. : Сов. энцикл., 1965.

24. Ташак В. И. Палеолитические и мезолитические памятники УстьКяхты. Улан-Удэ : Изд-во БНЦ СО РАН, 2005. 130 с.

25. Цыденова Н. В. Поселение неолита-средневековья Муханские озера (Западное Забайкалье) // Вестник НГУ. Серия: История, филология. 2009. Т. 8, вып. 5: Археология и этнография. С. 123-131.

\section{References}

1. Raskopki zhilishcha na Nur-Tukhumskom arkheologicheskom komplekse [Dwelling excavations at Nur-Tukhum archaeological complex] / B. A. Bazarov, D. A. Miyagashev, N. V. Imenokhoev, A. M. Klementyev // Povolzhskaja archeologija [Volga archaeology]. 2019. № 4 (26). Pp. 84-97. [In Russ.].

2. Baranov V. S. Celostnost' arkheologicheskikh kollekcij v muzejnom khranenii: Effekt «raspredmechivanija» [Integrity of archaeological collections in museum conservation. The effect of «desobjectivation» // Arkheologija Evrazijskikh stepej [Archaeology of Eurasian steppes]. 2019. № 5. Pp. 66-75. [In Russ.].

3. Berdnikova N. E. Arkheologicheskije ob"ekty, kollekcii i problemy khranenija [Archaelogical objects, collections and problems of conservation] // Izvestija Irkutskogo gosudarstvennogo universiteta. Serija: Geoarkheologija. Etnologija. Antropologija [News of Irkutsk state university. Series: Geoarchaeology. Ethnology. Anthropology]. 2014. V. 10. Pp. 94-109. [In Russ.].

4. Vorobyeva S. L. Komplektovanije, uchjet, khranenije i nauchnoe opisanije arkheologicheskikh kollekcij v muzejakh: pravovyje aspekty i prakticheskij opyt. Nauchno-metodicheskoe posobije [Acquisition, recording, conservation and scientific description of archaeological collections in the museums: legal aspects and practical experience]. Ufa, 2019. 160 p. [In Russ.].

5. Grigoryev G. P. O predmete arkheologii [About the subject of archaeology] // Tezisy dokladov sessii, posvjashchennoj itogam polevykh arkheologicheskikh issledovanij $1972 \mathrm{~g}$. v SSSR [Abstracts of the session reports devoted to 
the results of the field archaeological research of 1972 in the USSR]. Tashkent, 1972. Pp. 41-48. [In Russ.].

6. Davydova A. V. Ivolginskij kompleks (gorodishche i mogil'nik) - pamjatnik khunnu v Zabajkal'je [The Ivolginsk complex (settlement and burial ground) - monument to the Huns in Transbaikalia]. L., 1985. 111 p. [In Russ.].

7. Dashibalov V. V. Ocherki po drevnej i srednevekovoj istorii mongolov $i$ burjat [Feature articles in ancient and middle age history of the Mongols and Buryats]. Ulan-Ude, 2002. 81 p. [In Russ.].

8. Metodicheskije rekomendacii po formirovaniju, uchjetu, khraneniju i ispolzovaniju geologicheskikh kollekcij [Methodical recommendations in forming, recording and conserving geological complexes] / I. M. Zadorozhniy, A. A. Ivanov, L. R. Kolbancev, A. M. Karpunin. M., 2005. 54 p. [In Russ.].

9. Ivashina L. G. Neolit i eneolit lesostepnoj zony Burjatii [Neolithic and Eneolithic of the forest and steppe zone of Buryatia]. Novosibirsk, 1979. 157 p. [In Russ.].

10. Kazantseva O. A. Delit' nel'zja izuchat' (celostnost' arkheologicheskoj kollekcii: vozmozhnosti i trudnosti nauchnogo issledovanija) [You cannot divide but study (integrity of archaeological collections: possibilities and challenges of the scientific study] // Arkheologija Evrazijskikh stepej [Archaeology of the Eurasian steppes]. 2019. № 5. Pp. 57-66. [In Russ.].

11. Kamenitskiy I. S., Marshak B. I., Sher Ya. A. Analiz Arkheologicheskogo istochnika: vozmozhnosti formalizovannogo podkhoda [Analysis of the archaeological source: possibilities of the formalized approach]. $2^{\text {nd }}$ ed. M., 2013. 182 p. [In Russ.].

12. Kleyn L. S. Arkheologicheskije istochniki : ucheb. posobije [Archaeological sources : manual]. Leningrad. 1978. 119 p. [In Russ.].

13. Kolpakov Ye. M. Pochemu «arkheologicheskije istochniki?» [Why are «the archaeological excavations? » // Arkheologicheskije istochniki [Archaeological sources] / L. S. Kleyn. $2^{\text {nd }}$ ed., enl. S.-P., 1995. Pp. 302-327. [In Russ.].

14. Kononchuk K. V. Arkheologicheskaja kollekcija muzeja-zapovednika «Tomskaja Pisanica» kak istochnik po drevnejshej istorii juga Nizhnego Pritomja : preprint [Archaeological collection of the museum-reserve «Tomskya Pisanitsa» as the source in ancient history of the south of Nizhny Pritomye // Istorikokul'turnyj i prirodnyj zapovednik «Tomskaja pisanica» [Historical and cultural nature reserve «Tomskya Pisanitsa»]. F. 5. Inv. 1. C. 28. 13 p. [In Russ.].

15. Lbova L. V. Paleolit severnoj zony Zapadnogo Zabajkal'ja [Paleolithic of the northern zone of Western Transbaikalia]. Ulan-Ude, 2000. 240 p. [In Russ.].

16. Lbova L. V., Zhambaltarova Ye. D., Konev V. P. Pogrebal'nyje kompleksy neolita-rannego bronzovogo veka Zabajkal'ja (formirovanije arkhetipov pervobytnoj kul'tury) [Burial complexes of Neolithic - early Bronze age of Transbaikalia (formation of the primitive culture archetypes]. Novosibirsk, 2008. 248 p. [In Russ.].

17. Metodika obrabotki kollekcij : ucheb. posobie [Methods of collection processing : manual / A. P. Borodovskiy, L. V. Lbova, V. P. Mylnikov, L. N. Mylnikova, T. I. Nokhrina, I. V. Salnikova. Novosibirsk, 2013. 391 p. [In Russ.]. 
18. Myasnikov V. Yu., Yaroslavtseva L. G. Tri srednevekovykh klinka iz kollekcii nacional'nogo muzeja Respubliki Burjatija [Three middle-aged blades from the collection of the national museum of the Republic of Buryatia] // Teorija i praktika arkheologicheskikh issledovanij [Theory and practice of the archaeological research]. 2017. № 3 (19). Pp. 57-68. [In Russ.].

19. Rossijskaja muzejnaja enciklopedija [The Russian museum encyclopedia]. URL: http://museum.ru/rme/rme.htm [17.05.2020]. [In Russ.].

20. Rusina Yu. A. Istochnikovedenije novejshej istorii Rossii : ucheb. posobije [Source study of the recent history of Russia : manual]. Ekaterinburg. 2015. 236 p. [In Russ.].

21. Simukhin A. I. Tekhnologicheskije tradicii v proizvodstve izdelij iz cvetnogo metalla v Zabajkal'je (II tys. do n.e - XIX v.) : avtoref. dissert. .... kand. ist. nauk [Technological traditions in the production of items from nonferrous metal in Transbaikalia (II ${ }^{\text {nd }}$ millennium BC - XIX century] : dissertation thesis ... candidate of historical sciences]. Ulan-Ude, 2006. [In Russ.].

22. Simukhin A. I. Kollekcija bronzovykh nozhej muzeja Burjatskogo nauchnogo centra SO RAN (II-I tys. do n.e.) [The collection of the bronze knives of the museum of the Buryat scientific center of the SB RAS] // Drevnije kul'tury Mongolii i Bajkal'skoj Sibiri : materialy IV mezhdunar. nauch. konf. [Ancient cultures of Mongolia and Baikal Siberia : materials of the $4^{\text {th }}$ intern scient. conf.]. In 2 v. Part 2 (Chita, 13-19 Sept. 2013). Chita, 2013. Pp. 277-287. [In Russ.].

23. Sovetskaja istoricheskaja enciklopedija [The soviet historical encyclopedia] / chief ed. Ye. M. Zhukov. M., 1965. [In Russ.].

24. Tashak V. I. Paleoliticheskije i mezoliticheskije pamjatniki UstKyakhty [Paleolithic and Mesolithic monuments of Ust-Kyakhta]. Ulan-Ude, 2005. 130 p. [In Russ.].

25. Tsydenova N. V. Poselenije neolita-srednevekov'ja Mukhanskije ozera (Zapadnoje Zabajkal'je) [Settlement of Neolithic-middle aged Mukhansky lakes (Western Transbaikalia] // Vestnik NGU. Serija: Istorija, filologija. 2009. V. 8, vypusk 5: Arkheologija i etnografija [Bulletin of NSU. Series: History, Philology. 2009. V. 8, issue 5: Archaeology and Ethnography]. Pp. 123-131. [In Russ.]. 
DOI 10.31443/2541-8874-2020-3-15-73-80

УДК 930.25(571.53)+929.5(=512.31)

Аюшеева М. В.

Ausheeva M. V.
ОБЗОР БУРЯТСКИХ РОДОСЛОВНЫХ В ЛИЧНОМ АРХИВНОМ ФОНДЕ Ж. А. ЗИМИНА (1920-2012)

\section{THE BURYAT GENEALOGIES REVIEW IN THE PERSONAL AR- CHIVAL FUND OF ZH. A. ZIMIN (1920-2012)}

В статье дана характеристика и история формирования личного архивного фонда Жана Александровича Зимина, педагога, литератора и краеведа, хранящегося в Центре восточных рукописей и ксилографов ИМБТ СО РАН. Среди архивных материалов выделены материалы по бурятским родословным. Генеалогические материалы сгруппированы по типу отражаемой информации на план-схемы и родословные. Отмечено, что личный фонд Ж. А. Зимина является востребованным для восстановления как частной генеалогии отдельных лиц, так и истории бурят.

The article gives the characteristic and history of the personal archival fund formation of Zhan Alexandrovich Zimin, a teacher, writer and local historian, stored at the Center of Oriental Manuscripts and Xylographs of the IMBTS SB RAS. The materials on the Buryat genealogies are identified among the archival materials. The results of the activity on collecting Buryat family trees are considered. The genealogy materials are grouped into plan-schemes and genealogies according to the type of the information reflected. It is noted that $\mathrm{Zh}$. A. Zimin's personal fund is in demand for restoring both the individuals' private genealogies and the history of the Buryats.

Ключевые слова: архивные материалы, родословные, Ж. А. Зимин, личный фонд, буряты, ЦВРК.

Keywords: archival materials, genealogies, Zh. A. Zimin, personal archive, the Buryats, COMX.

В этом году исполняется 100 лет со дня рождения Жана Александровича Зимина (1920-2012), кандидата географических наук, заслуженного учителя Российской Федерации, литератора, этнографа, краеведа, действительного члена Географического общества, почетного жителя Аларского района Иркутской области.

Ж. А. Зимин родился 20 сентября 1920 г. в улусе Аляты Балаганского округа (ныне Аларский район) Иркутской области. Биография Ж. А. Зимина, его творческий путь нашли отражение в ряде юбилейных изданий и научных статьях $[1 ; 2 ; 3 ; 4]$. В жизненном пути Жана Александровича было три

${ }^{1}$ Исследование выполнено при финансовой поддержке РФФИ в рамках научного проекта № 18-49-030011 «Исследование корпуса бурятских родословных в Центре восточных рукописей и ксилографов ИМБТ СО РАН». 
большие стези, которые он блестяще реализовал: педагог, литератор, ученый. После окончания школы 17-летний Жан был приглашен на должность учителя и всю свою жизнь посвятил просветительству. В 1951 г. окончил географический факультет Иркутского государственного университета. Преподавал географию в школах Аларского района и Республики Бурятия. В системе образования Жан Александрович проработал более 50 лет, был учителем в разных школах, завучем, директором, методистом. Учительство он считал своим призванием и выделял его из ряда других своих занятий. Делился своим богатым жизненным и педагогическим опытом, издал ряд учебно-методических пособий, монографических исследований, а также большое количество научно-краеведческих, публицистических статей в разных журналах и газетах [5]. Особо стоит отметить его литературную деятельность: творчество для детей, пьесы (часть вошла в репертуар профессиональных и непрофессиональных театров), стихотворения, в которых ярко прослеживается лирическая натура автора.

Научные труды Ж. Зимина отличает системный подход к рассматриваемым предметам. Как отмечено в рецензии на его труды, «в своих исследованиях Жан Александрович рассматривает факты и явления во взаимосвязи, комплексом проблем человеческой деятельности» [6]. Вполне закономерно, что его интересы в краеведении уходят в изучение вопросов исторического прошлого бурят, отсюда необходимость знания генеалогии, особенностей природопользования и хозяйствования, материальной и духовной культуры того или иного рода. Все это требовало комплексного рассмотрения с фольклором, традициями и обычаями.

По-своему красноречив и иллюстративен один документ из личного архива Ж. А. Зимина, где отражена и работоспособность, и целеустремленность, и сила воли, и жажда к труду. Озаглавлен он так: «Что я делал за период с сентября 2003 г. по март 2004 г.», составлен 28 марта 2004 г. На листе формата A4 представлен список проделанной работы по месяцам: в сентябpe 2003 г. состоялась защита диссертации на соискание ученой степени кандидата географических наук по теме «Природно-экологические ситуации Приангарской лесостепи» в Восточно-Сибирском институте географии СО РАН (Иркутск); в октябре была сдана в печать монография «Аларь: история и современность»; в ноябре Ж. Зимин работал над составлением библиографического указателя своих опубликованных произведений, педагогических и публицистических, научных работ (408 наименований); в декабре писал монографию «Моя педагогическая философия»; в январе собирал материалы для будущей книги о Г. П. Абашееве; в феврале разрабатывал план новой монографии «Из этнической истории присаянских хонгодоров» (аларских, тункинских, окинских); а в марте подбирал материалы для новой книги «Педагогический портфель» (об учителях Аларского района - мастерах педагогического труда). Последняя запись в данном списке: «27 марта исполнилось 65 лет моей педагогической, литературной и научной деятельности» [6, л. 6].

За заслуги перед своей малой родиной, за его неутомимый труд в деле просветительства и изучения родного края, в честь 75-летия знаменитого 
земляка, постановлением Алятской сельской администрации от 29 февраля 1996 г. было решено переименовать улицу Почтовая в селе Аляты в улицу имени Ж. Зимина [6, л. 30]. А в августе 2002 г. Ж. А. Зимину было присвоено звание «Почетный гражданин Аларского района».

Многогранность его деятельности и широкий диапазон проделанной работы хорошо отражены в архивных материалах. Личный архивный фонд Жана Александровича Зимина представлен в Центре восточных рукописей и ксилографов ИМБТ СО РАН под номером 26 в пяти описях.

Первоначально фонд был принят на хранение в 1989 г. После замечаний оценочной комиссии, в которую вошли К. Д. Басаева, С. С. Бардаханова, Ц. Б. Цыдендамбаев и другие сотрудники Бурятского института общественных наук (ныне ИМБТ СО РАН), Ж. Зимин провел доработку своих материалов. Дополнил паспортизацию фольклорных записей, уточнил сведения о родословных. Он сообщает в дневнике, что весь март работал над замечаниями К. Д. Басаевой по этнографии. На воскресенье 2 апреля им были доработаны план-схемы населенных пунктов Халта, Ныгда, Бурков, Нарены, Кукунур, Куркат, Киркей, Алят и Куйты. Оставалось внести дополнения в план-схемы сел Алзобей и Шалоты. В основном дополнял графу «род» и писал приложения по план-схемам. Как пишет сам Ж. Зимин, работа немного муторная и отнимала много времени: «Казалось, работы немного. Оказалось, хлопот было достаточно. На семь населенных пунктов потратил добрых три дня» [7, л. 39].

Понимая важность своей собирательской и научной деятельности, нуждался в поддержке и поощрении своих занятий, намеревался продолжать сотрудничество с БИОНом: «Это сотрудничество я не должен обрывать. Никоим образом» [7, л. 29]. Общение с учеными из БИОНА, их доброжелательность и советы ободряли Жана Александровича, он искренне был рад той поддержке, которую ему оказывала С. Бардаханова. Ему было приятно услышать от К. Басаевой высокую оценку его материалов по этнографии и собирательской деятельности, которую он характеризует следующим образом: «Только я сам не придаю своему хождению собирательскому особого значения. Для меня это - в порядке вещей. Я нахожу в хождении своего рода стихию свою» [7, л. 14].

Решение о принятии его фонда на хранение в Рукописный отдел Бурятского института общественный наук (ныне ЦВРК ИМБТ) явилось знаковым событием для самого Ж. А. Зимина. В дневниках за этот период он описывает свои переживания так: «Это - событие. Это - победа. И нравственная, точнее моральная и материальная». «Считаю: это - огромная победа! Признан мой многолетний собирательский труд. Мой фонд станет предметом исследований» [7, л. 34, 42]. Судьба своих материалов сильно заботила Ж. Зимина, он писал: «среди осуществленных, осуществимых и не осуществленных забот-хлопот, самое главное в данное время - это Фонд, принятый (фактически) БИОНом» [7, л. 41].

Он был горд, что его материалы послужат последующим поколениям: «Можно сказать. Мои деяния увековечены. Жизнь моя не бесследна. ... Ну, кто из просвещенцев-бурят располагает фондом в наше время? Молод- 
цы же Онгодов, Хангалов, Балдаев, Мадасон - все они работали учителями. Нелегкий учительский труд сочетали с собирательской работой. Да и сама собирательская работа - это подвижническое дело. Пешком, в телеге на лошади, на машине (авто), мотоцикле и в дождь, и в жару, и в мороз ходишь из дома в дом. От знатока к знатоку - собираешь мифы, легенды, предания, были, рассказы. Сказки, песни, загадки, проклятия, благопожелания. Родословные, родовой состав, воспоминания и т.д. Да и иметь надо подход к миру того или иного знатока старины, информатора. Располагать надо определенной методикой записывания, опроса, беседы. Надо быть и психологом иметь такт, не утомлять, не назидать, не наводить скуку. Собирательские «сеансы» должны быть разнообразными: побуждать информатора к воодушевлению, охоте рассказывать, желать перерыв, самому рассказывать и т.д.» [7, л. 35-36].

Ж. Зимин планировал дальше пополнять свои фонды. О чем имеется запись в дневнике: «Удастся ли столько же собрать за 2-3 года? Если удастся, было бы хорошо» [7, л. 42]. В планах на год, отмечал, что летние месяцы посвятит, в основном, собирательской работе. При этом давал себе установку о том, что «надо разработать более или менее совершенно методику записывания материалов от информаторов, а также с архивов, документов и др. источников» [7, л. 41].

После принятия в 1989 г. личного архива Ж. А. Зимина на хранение в общий фонд Рукописного отдела, лишь в 1996 г. была завершена его научно-техническая обработка. Из сданных фондообразователем 257 папок была сформирована первая опись личного фонда Ж. А. Зимина в составе 247 единиц хранения. Сокращение количества папок произошло в виду объединения ряда дел по тематическому принципу.

По большей части материал представлен в рукописном виде, имеются и машинописные, печатные документы. В личном фонде исследователя выделено несколько крупных блоков, как: творческие материалы, куда вошли его литературные труды, поэтические работы, пьесы, материалы по языкознанию; и материалы, собранные фондообразователем, среди них следует отметить: историко-этнографические и фольклорные материалы, газетные вырезки, программы и фотографии спектаклей.

В последующие годы Ж. А. Зимин пополнял и расширял свой фонд новыми материалами, не только собранным им полевым материалом, но и рукописями статей, монографий, документами, отражающими его творческую и общественную деятельность. Стоит отметить, что весьма скудно представлены биографические документы, в основном, они касаются защиты кандидатской диссертации, юбилейных мероприятий.

Во вторую опись, пополнившую фонд в 2000 г., вошло 93 единицы хранения. В 2006 г. Ж. А. Зиминым сданы в Центр восточных рукописей и ксилографов материалы, доработанные и вновь собранные во время командировок. После НТО было сформировано 142 ед. хр., составивших третью опись его личного фонда. Четвертая опись была сформирована в 2008 г. в составе 30 ед. хр. Пятую опись составили материалы по истории и родословным жителей Аларского района, изучению Гэсэра, хозяйственной куль- 
туре Окинского района, здесь также представлены личная переписка и дневники ученого. В пятую опись включено 32 ед. хр. Таким образом, личный архивный фонд Ж. А. Зимина составляет 544 ед. хр. В нем отложились как опубликованные материалы, так и черновики, рукописи монографий, пособий и статей.

Как уже отмечено выше, к собиранию своих материалов Ж. Зимин относился очень ответственно. Особое место в собранном им этнографическом материале занимают бурятские родословные. Среди материалов по генеалогиям можно выделить родословные частных лиц, например, дело № 91, опись 3 «Генеалогическое древо жителя с. Кижинга Балдандоржиева Пунцыка» на 1 листе, так и генеалогические таблицы родов (например, дело № 7, опись 5 «Род шоно ураг»), населенных пунктов. Генеалогические таблицы родов представлены, в основном, в виде линейной записи сверху вниз. Родословные населенных пунктов, главным образом, представлены в виде план-схем, где схематически изложен план поселения: улица за улицей, дом за домом. По этим картам можно увидеть, кто с кем соседствовал, где располагалась школа или магазин. Все скрупулезно было зафиксировано собирателем. Каждое домохозяйство представлено в виде отдельной окружности, поделенной пополам, в одной из половин записан глава семейства, в другой - его супруга с указанием рода. Ж. А. Зиминым была разработана специальная система отражения родовой принадлежности: каждому роду было присвоено отдельное графическое обозначение, например, рисунок из букв «г» обозначал род галзутов. Каждая план-схема населенного пункта имела «легенду», расшифровку графических обозначений.

Собранные Ж. А. Зиминым материалы отличает еще одна особенность: по ним можно выявить родословную со стороны матери. В то время как среди большинства представленных в фондах ЦВРК материалов записаны только предки по мужской линии, иногда даже без указания имен дочерей. В докладе «Генеалогия бурят как национально-культурная традиция» на окружной научно-практической конференции «Музей настоящего и будущего: традиции, обычаи народов Сибири», посвященной 55-летию Государственного национального музея Усть-Ордынского Бурятского автономного округа (май 1999 г.) Ж. А. Зимин изложил свои размышления о необходимости записи и сбора родословных как по отцовской, так и по материнской линии: «существовала традиция знания родословной по материнской линии. Она бытовала в улусах Западной Бурятии до недавних лет (50-е - 70е гг.). Во время бесед хозяев и гостей было обычаем задавать вопрос: «Нагасанадай найман үе нэрлэгты», т.е. перечислите предков по матери до 8 поколений» [8].

«На наш взгляд, мужские генеалогии представляют все же неполный источник для современной этнографии, демографии, антропонимии. В своей практике, как правило, мы придерживаемся составления генеалогических таблиц как по мужской, так и по женской линии. Ц. Б. Цыдендамбаев придерживался записи родословных и по мужской, и по женской линии. Особенно большое внимание он уделял на так называемое нагасачество, т.е. на родственников жены и матери мужа. Он указывал на то, что невестки, прие- 
хавшие из другого рода, вводят в родовую среду мужа особенности в языке, обрядах, ритуалах и других традиционных процессах, бытовавших ранее в ее роде» $[8$, л. 7$]$.

Поясняя важность знания рода, ученый углубляется в историю сложения бурятских родов. «С развитием производительных сил и разделением труда в древнем обществе материнский род сменялся отцовским. ... История рода стала отсчитываться с главы рода, т.е. родоначальника. От него отсчитывалось и генеалогическое древо. Генетически связанные роды составляли племя. Роды, численно увеличиваясь, расширяя территории расселения, особенно с развитием скотоводства, разделялись на рода и подроды. В процессе социального расслоения подроды делились на фамильные кланы. Когда семья формировалась как самостоятельная социально-этническая ячейка, образовывала она фамильную генеалогию. Таким образом, бурятская генеалогия составляет систему этнических родословных подразделений. Это генеалогия племенная, родовая, подродовая, фамильная, семейная, личная» [8, л. 2].

О ценности материалов по родословным бурят и их научнопрактическому применению Ж. А. Зимин пишет: «Генеалогическая таблица представляет важный источник антропологических, этнических, демографических и лингвистических исследований. На основе генеалогических данных можно составлять словарь имен и выяснять их происхождение, воссоздавать этнически родственные связи, устанавливать генетическую наследственность, историю своей семьи, фамильной ветви, познавать семейные, фамильные, родовые традиции, обычаи, обряды» [8, л. 4]. В данном же докладе Ж. Зимин отдельно остановился на пользе сведений из родословных для проведения генетических исследований для изучения наследственности; что ранее на родословие смотрели при выборе супругов «удха узуур хараха». O применении и дальнейшем использовании своих материалов ученыйкраевед предполагает, что «после обработки, думается, они послужат источниками для монографического исследования, могут быть использованы как музейные экспонаты и способствовать дальнейшему развитию национальных этнокультурных традиций и пропаганде их среди нынешней ассимилирующейся молодежи, а также среди школьников и дошкольников» $[8$, л. 9].

На начало 2000-х гг. исследователь сообщает, что им собраны генеалогические древа, родословные составы бурят в более чем 20 районах Западной и Восточной Бурятии. Но это еще не окончание его собирательской деятельности. Об устремленности Жана Александровича, можно сказать, рвении к сохранению, пропаганде бурятской духовной культуры красноречиво говорят строки его письма от 8 июня 2004 г. на имя главы администрации Усть-Ордынского Бурятского автономного округа В. Г. Малеева: «Всю жизнь «пешкодралом», слабеют ноги, хожу из села в село, собираю материалы, прихрамывая. Прошу Вас выделить мне легковую машину, так как я намерен продолжать сбор полевых материалов для новых работ» [6, л. 10].

В заключение отметим, что материалы личного фонда Ж. Зимина отражают его широкий кругозор, эрудицию и тягу к познанию нового, они востребованы среди ищущих свои корни, восстанавливающих родовую при- 
надлежность и генеалогию, интересующихся историей Оки, Алари (двух главных мест воспетых и скрупулезно изучаемых в научном и творческом наследии Ж. Зимина). Представленные материалы в пяти описях, в виду своей постепенной передачи на постоянное хранение, по тематическому принципу разбросаны, потому для более эффективного изучения творческого наследия Ж. Зимина следует создать указатель, либо аннотированный каталог. Собранные им материалы с каждым годом обретают все большую научную ценность и значимость.

\section{Примечания}

1. Шулунова-Баирова Л. В. Любя свой труд и не прельщаясь славой... (к 85-летию со дня рождения Жана Александровича Зимина): биография отдельного лица. Улан-Удэ, 2006. 31 с.

2. Календарь знаменательных и памятных дат на 2020 год. Аларский район : библиогр. указ. / МБУК «Межпоселенческая центральная библиотека им. А. В. Вампилова»; сост. М. А. Атанова. Кутулик, 2019. 34 с. : фот.

3. Жапов В. Д. Творчество Ж. А. Зимина для детей // Мир Центральной Азии : материалы Междунар. науч. конф. / отв. ред. Б. В. Базаров. УланУдэ : Изд-во БНЦ СО РАН, 2002. С. 64-68.

4. Ринчинов О. С. Источники по бурятским генеалогиям: проблемы цифровой обработки на примере фонда Ж. Зимина // Улан-Удэ - 350 лет: история, пространство, общество : сб. науч. ст. / отв. ред. Б. В. Базаров. Иркутск : Оттиск, 2016. С. 471-476.

5. Жан Александрович Зимин : библиогр. указ. : к 90-летию со дня рождения / сост. Ж. А. Зимин, ред. Б. С. Дугаров. Улан-Удэ. 2009. 42 с.

6. ЦВРК ИМБТ СО РАН (Центр восточных рукописей и ксилографов Института монголоведения и буддологии Сибирского отделения Российской академии наук). ЛАФ (Личный архивный фонд) № 26. Оп. 3. Д. 1, 30 л.

7. ЦВРК ИМБТ СО РАН. ЛАФ. № 26. ОП. 2. Д. 62. Дневник № 1.

8. ЦВРК ИМБТ СО РАН. ЛАФ. № 26. Оп. 2. Д. 20, 10 л.

\section{References}

1. Shulunova-Bairova L. V. Ljubja svoj trud i ne prel'shchajas' slavoj... (k 85-letiju so dnja rozhdenija Zhana Aleksandrovicha Zimina): biografija otdel'nogo lica [Loving one's own work and not being attracted by glory... (to the 85th anniversary of the birth of Zhan Alexandrovich Zimin): individual's biography]. Ulan-Ude, 2006. 31 p. [In Russ.]

2. Kalendar' znamenatel'nykh i pamjatnykh dat na 2020 god: Alarskij rajon: bibliogr. ukaz. / MBUK «Mezhposelencheskaja central'naja biblioteka im. A. V. Vampilova» [Calendar of significant and memorable dates in 2020: the Alarsky district: bibliography / MBIC "Inter-Settlement Central Library named after A. V. Vampilov"; comp. by M. A. Atanova]. Kutulik, 2019. 34 p. : photo 3. [In Russ.]

3. Zhapov V. D. Tvorchestvo Zh. A. Zimina dlja detej [Creativity of Zh. A. Zimin for children] // Mir Central'noj Azii : mat-ly mezhdunar. nauch. konf. 
[The world of Central Asia : materials of the intern. scient. conf.]/ ed. by B. V. Bazarov]. Ulan-Ude, 2002. Pp. 64-68. [In Russ.]

4. Rinchinov O. S. Istochniki po burjatskim genealogijam: problemy cifrovoj obrabotki na primere fonda $\mathrm{Zh}$. Zimina [The Buryat genealogical sources: the problems of digitalization on the example of Zh. Zimin's collection] // UlanUde - 350 let: istorija, prostranstvo, obshchestvo : sb. nauch. st. [Ulan-Ude - 350: history, space, society: collection of articles / chief editor B. V. Bazarov]. Irkutsk, 2016. Pp. 471-476. [In Russ.].

5. Zhan Aleksandrovich Zimin: bibliogr. ukaz. : k 90-letiju so dnja rozhdenija [Zhan Alexandrovich Zimin: bibliographic index: to the 90th anniversary of the birth] / comp. by Zh. A. Zimin, ed. by B. S. Dugarov]. Ulan-Ude, 2009. 42 p. [In Russ.].

6. CVRK IMBT SO RAN (Centr vostochnykh rukopisej i ksilografov Instituta mongolovedenija i buddologii Sibirskogo otdelenija Rossijskoj akademii nauk) [COMX IMBTS SB RAS (Center of oriental manuscripts and xylographs of the Institute for Mongolian, Buddhist and Tibetan Studies of the Siberian branch of the Russian academy of sciences)]. LAF (Lichnyj arkhivnyj fond) [PAF (Personal archival fond)]. No. 26. Inv. 3. C. 1. 30 1. [In Russ.].

7. CVRK IMBT SO RAN [COMX IMBTS SB RAS]. No. 26. Inv. 2. C. 62. Dnevnik [Diary] № 1. [In Russ.].

8. CVRK IMBT SO RAN [COMX IMBTS SB RAS]. No. 26. Inv. 2. C. 20. 101. [In Russ.]. 
DOI 10.31443/2541-8874-2020-3-15-81-88

УДК 378.6(571.54-25)

Немчинова Т. А., Цыремпилова И. С.

Nemchinova T. A., Tsyrempilova I. S.

«С ЧЕГО НАЧИНАЕТСЯ ВСГИК?»: СТЕНОГРАММА

ТОРЖЕСТВЕННОГО ЗАСЕДАНИЯ, ПОСВЯЩЕННОГО ОТКРЫТИЮ

ВОСТОЧНО-СИБИРСКОГО БИБЛИОТЕЧНОГО ИНСТИТУТА

\section{«WHAT DOES ESSIC BEGIN WITH?»: THE TRANSCIPT OF THE CEREMONIAL MEETING DEDICATED TO THE OPENING OF EAST- SIBERIAN LIBRARY INSTITUTE}

Статья раскрывает информационный потенциал документа «Стенограмма торжественного заседания, посвященного открытию ВосточноСибирского библиотечного института», находящегося на хранении в архиве ВСГИК. Авторами рассмотрен один из первых неопубликованных документов по истории вуза, отражающий детали и факты торжественного события, приуроченного к его открытию.

The article reveals the information potential of the document "The record of the ceremonial meeting dedicated to the opening of East-Siberian library Institute", which remains stored in the archives of East-Siberian state Institute of culture. The authors have examined one of the first unpublished documents in the history of the institute reflecting the details and facts of the ceremonial meeting dedicated to its opening.

Ключевые слова: Восточно-Сибирский библиотечный институт, Восточная Сибирь, Дальний Восток, подготовка кадров, культура, стенограмма, источник

Keywords: East-Siberian Library Institute, Eastern Siberia, the Far East, staff training, culture, transcript, source.

История Восточно-Сибирского государственного института культуры - это 60 лет, в течение которого небольшой библиотечный институт прошел путь до многофункционального образовательного учреждения, осуществляющего подготовку по десяткам востребованных направлений подготовки и специальностей, ведущего активную научно-исследовательскую и творческо-исполнительскую деятельность, прочно занимающего свою нишу в региональной системе высшего образования.

20 сентября 1960 г. Совет Министров СССР принял постановление № 1008: «Принять предложение Совета Министров РСФСР, согласованное с Министерством высшего и среднего специального образования СССР, об организации в 1960 г. в г. Улан-Удэ Восточно-Сибирского библиотечного института». 13 октября 1960 г. Совет Министров Бурятской АССР принимает постановление об открытии с 1 ноября 1960 г. института и его временном размещении «в здании по улице Рабочая 16 с полезной площадью 1146 кв. 
метров и под общежитие здание по улице Пионерская 3 на 100 мест» [2, с. $107]$.

Создание института стало важнейшим этапом реализации государственной программы культурного строительства на территории Восточной Сибири, Дальнего Востока и Севера и позволило в короткие сроки решить проблему подготовки кадров для учреждений культуры на востоке страны.

Многолетняя и насыщенная событиями история института нашла отражение в документах, воспоминаниях, юбилейных изданиях, научных публикациях и др. Особый исследовательский интерес, вне всякого сомнения, представляют архивные документы, среди которых «Стенограмма торжественного заседания, посвященного открытию Восточно-Сибирского библиотечного института, состоявшегося 30 ноября 1960 г.».

Вводная часть документа содержит сведения о датировке. Стенограмма датируется 30 ноября 1960 г., г. Улан-Удэ. Документ не опубликован. Количество - 1 ед., 20 листов, машинописный набор. Место хранения Архив ВСГИК.

Основная часть стенограммы включает (персоналии, наименования должностей, учреждений, городов приведены как в тексте документа):

1. Доклад директора Института Жалсабона.

2. Поздравительные адреса/приветственные слова:

- от органов власти (Хахалов, Председатель Президиума Верховного Совета Бурятской АССР, Дондуков, секретарь Улан-Удэнского горкома КПСС, Жалсараев, министр культуры Бурятской АССР, Дамбаев, секретарь Бурятского обкома ВЛКСМ, Цыремпилон, секретарь Улан-Удэнского горкома ВЛКСМ);

- от научных организаций (Очиров, заместитель директора Бурятского Комплексного Научно-исследовательского института Сибирского Отделения Академии Наук);

- от образовательных организаций (Амоголонов, Бурятский педагогический институт им. Доржи Банзарова, Васильев, Бурятский сельскохозяйственный институт);

- от учреждений культуры и искусства (Гофман, Заслуженный деятель искусств Бурятской АССР, Государственный русский драматический театр, Лоханина, Республиканская библиотека им. А.М. Горького);

- от общественных объединений (Батубаев, Союз художников Бурятской АССР, Жимбиев, Союз писателей Бурятской АССР).

3. Поздравительные телеграммы:

- от органов управления культурой других регионов (Министерство культуры Якутской АССР, Красноярское краевое управление культуры, Управление культуры Томского облисполкома, Управление культуры Сахалинского облисполкома, Камчатки);

- от общественных организаций (обком профсоюзов работников культуры);

- от образовательных организаций (Ленинградский библиотечный институт, Московский библиотечный институт, Улан-Удэнское музыкальное училище имени П.И. Чайковского, культпросветучилище); 
- от учреждений культуры и искусства (Государственная библиотека им. В.И. Ленина, Бурятский театр драмы имени Хоца Намсараева, Бурятское книжное издательство).

4. Ответное слово (Мохов И.А.).

Постановляющая часть стенограммы представлена принятым на торжественном заседании письмом в адрес ЦК партии и Совета Министров РСФСР.

Документ не содержит подписей, заверяющих стенограмму, только датировку. К сожалению, остается открытым вопрос о наличии копий стенограммы, текстах поздравительных адресов и телеграмм.

Основной исследовательской задачей является определение информационного потенциала документа. Анализ «Стенограммы торжественного заседания, посвященного открытию Восточно-Сибирского библиотечного института» свидетельствует о том, что в день открытия вуза был вынесен широкий спектр вопросов и проблем, требующих решения и не теряющих своей актуальности сегодня.

Основное место в стенограмме занимает доклад директора ВосточноСибирского библиотечного института Д.Ж. Жалсабона. Руководитель нового вуза сразу обозначил перспективы его развития: «На новый ВосточноСибирский библиотечный институт возложена подготовка специалистов выстей квалификачии культурно-просветительных, библиотечных работников для областей, краев, автономных республики Восточной Сибири и Дальнего Востока» и далее: «Институт имеет два факультета: факультет библиотековедения в будущем с кафедрами - библиография и библиотековедение, массовая библиотека, детская библиотека; факультет культурно-просветительной работы с кафедрами - хороведение и дирижирование, драматическая театральная самодеятельность, оркестр народных инструментов». В качестве ближайших задач были определены: контингент студентов свыше 1000 человек, в структуре института - более десяти кафедр, профессорско-преподавательский состав - свыше 100 человек. С поставленными задачами институт справился в короткий срок, так за 10 лет были сформированы 16 кафедр, на которых трудилось 160 педагогов, из них 154 штатных; было осуществлено 7 выпусков более 2-х тысяч специалистов клубной и библиотечной работы [1, с. 19-20].

В докладе нашла отражение специфика отбора будущих студентов, характерная для вузовской подготовки советского периода. В частности, наличие опыта работы в соответствующей отрасли для последующего поступления в институт. Об этом говорит Жалсабон на торжественном заседании: «Это соответствует условиям приема в Вузы студентов из числа молодежи после окончания десятилетки с практикой производственной работы, особенно по избранной профессии. Широко призываем для поступления в институт молодежь $c$ практикой библиотечной $и$ культурнопросветительной работы». Именно такой подход определял цель и содержание высшего образования, в основе которого была высокая мотивация студентов к получению профессии, в которой они себя уже «попробовали». 
Установленный приоритет для поступления в вуз представителей всех автономных республик, краев и областей Сибири и Дальнего Востока реализовывается во ВСГИК и сегодня. Так, он впервые был закреплен в основных тезисах, прозвучавших с высокой трибуны: «B числе студентов нашего института представители одиннадиати национальностей Сибири и Дальнего Востока: русские, буряты, якуты, алтайцьl, хакасы, эвенки и др.». 180 студентов первого набора являлись представителями Камчатки, Сахалина и Приморья, Красноярского, Хабаровского краев, Якутской АССР, Амурской, Новосибирской, Кемеровской, Иркутской, Читинской областей и Горного Алтая. Это являлось наглядным подтверждением реализации государственной национальной политики.

Качество подготовки специалистов во многом определяется уровнем профессорско-преподавательского состава. В связи с этим вопросы кадрового обеспечения учебного процесса в новом вузе были поставлены во главу угла. Для этого в первый год деятельности института были привлечены лучшие специалисты. Так «в числе приглашенных заведующий кафедрой библиографии Ленинградского библиотечного института, кандидат педагогических наук, дочент Мохов Иван Андреевич, декан факультета культурно-просветительной работы Борисов Николай Николаевич, окончивший аспирантуру Невский Владимир Андреевич, дочент пединститута Белоусов Андрей Андреевич, доцент по мастерству актера, режиссер Иофин Григорий Аронович и другие». Взвешенная кадровая политика, приглашение преподавателей и аспирантов из московских и ленинградских вузов, оказываемая методическая помощь и другие факторы заложили основы будущих педагогических и научных школ института.

Вопросы развития материально-технической базы института находят отражение в стенограмме торжественного заседания. В докладе директора института было отмечено, что уже в первые годы существования вуза Министерством культуры РСФСР были выделены средства на разработку проектно-сметной документации на строительство нового корпуса (в котором сегодня размещается ВСГИК), открытие фундаментальной библиотеки (основу фондов которой составили книги из центральных библиотек тогда Москвы и Ленинграда), приобретение специального учебного оборудования и музыкальных инструментов, в том числе 8 пианино, 20 баянов, 1 комплекта оркестра народных инструментов. Также была отмечена помощь со стороны органов региональной власти: Бурятского обкома КПСС, Президиума Верховного Совета и Совета Министров Бурятской АССР, которые выделили помещения для учебных занятий и общежития для студентов.

Интересным фактом является то, что в документе находит отражение факт первоначального размещения «младшего брата вузов Бурятской АССР» в том же здании, где в свое время располагались поочередно первые вузы республики - современные БГСХА им. В.Р. Филиппова и БГУ им. Д. Банзарова (ул. Рабочая, 16, пересечение улиц Ленина и Рабочей, сегодня ул. Сухэ-Батора, 16). Цитируя Жалсабона: «Кстати сказать, здание, в котором мы проводим наше торжественное собрание, является в известном смысле историческим: здесь было открыто первое учебное заведение рес- 
публики - Бурпедтехникум, здесь долгие годы размещались старейшие вузь республики: педагогический институт им. Доржи Банзарова и сельскохозяйственный институт».

Давая общую оценку выступлению директора института Жалсабона на таком ответственном мероприятии, следует отметить четкость и логичность построения доклада, который отвечал общепринятым в тот период идеологическим установкам. Текст стенограммы дает также полное представление о понимании руководством стоящих перед ним задач и основных ориентирах, о необходимости поэтапного развития создаваемого вуза, о видении первоочередных проблем, решением которых предстоит заниматься. Не менее важным в словах руководителя является призыв к плодотворной работе и творчеству.

Текст стенограммы содержит оценку и взгляд руководителей республики и города на открытие нового высшего учебного заведения в Восточной Сибири. На торжественном собрании присутствовали «первые лица» республики - Председатель Президиума Верховного Совета Бурятской АССР А.У. Хахалов, секретарь Улан-Удэнского горкома КПСС Дондуков, министр культуры Бурятской АССР Д.З. Жалсараев, секретарь Бурятского обкома ВЛКСМ Дамбаев, секретарь Улан-Удэнского горкома ВЛКСМ Цыремпилон.

А.У. Хахалов в приветствии участников торжественного собрания отмечает: «Открытие Восточно-Сибирского библиотечного института третьего по счету высшего учебного заведения в Бурятии стало возможно благодаря огромному подъему культуры, росту научных кадров в республике и является новым проявлением заботы нашей родной Коммунистической партии и Советского правительства о дальнейшем развитии советской культуры. Перед институтом поставлена благородная задача подготовки высококвалифицированных работников библиотек и культурнопросветительных учреждений». Продолжая поздравления, секретарь УланУдэнского горкома партии Дондуков, подчеркивает, что «napmuйнble u coветские органы сделали все возможное, чтобы помочь вам, молодому коллективу в создании материальной базы. При всей трудности с помещением, жильем, выделен вам прекрасный учебный корпус, неплохое здание общежития, укомплектован квалифицированными кадрами научнопедагогический состав. Теперь дело за вами. Учеба, как любой труд, требует от каждого из вас проявления настойчивости, силь воли. Думаю, что у студентов будет достаточно воли на преодоление трудностей, которые встретятся, и настойчивости для того, чтобы хорошо учиться». Представитель научного сообщества - заместитель директора Бурятского комплексного научно-исследовательского института СО АН общественности Ц.О. Очиров, в свою очередь, указывает на дальнейшие перспективы созданного института: «Восточно-Сибирский библиотечный институт, безусловно, станет не только цеентром подготовки высококвалифицированных кадров, работников культуры, но и одним из научно-исследовательских учреждений Бурятии».

Стенограмма имеет особое значение для изучения атмосферы важного для Бурятии события, понимания отношения к нему государственных и партийных органов, общественности. Язык документа, эмоциональная выра- 
зительность речевых оборотов, содержательная ценность провозглашаемых призывов и лозунгов, как ничто другое передают дух и тональность советской эпохи.

Текст стенограммы свидетельствует, что представители научных организаций, вузов, творческих объединений, учреждений культуры и искусства высказались о необходимости плодотворного взаимодействия и сотрудничества в целях развития системы высшего образования, как в республике, так и в Восточной Сибири. С приветствиями к коллективу и студентам вуза обратились Д.Д. Амоголонов (Бурятский педагогический институт им. Доржи Банзарова), К.А. Васильев (Бурятский сельскохозяйственный институт), Г.Р. Гофман, заслуженный деятель искусств Бурятской АССР (Государственный русский драматический театр), Лоханина (Республиканская библиотека им. А.М. Горького), Батубаев (Союз художников Бурятской АССР), Жимбиев (Союз писателей Бурятской АССР). Наряду с персоналиями можно извлечь дополнительную информацию о самих организациях. Например, о том, что в 1960 г. контингент студентов сельхозинститута составлял 2,5 тыс. чел., коллектив педагогического института - 3 тыс. чел., количество работников культуры Красноярского края - 10 тыс. чел.

В стенограмме представлен широкий круг пожеланий от коллег, в которых определяется будущая роль института в региональном развитии. «Коллектив Восточно-Сибирского библиотечного института окажет серьезную научно-педагогическую и практическую помощь учреждениям культуры республики» (Министерство культуры Бурятской АССР), «призван готовить кадры библиотечных и культурно-просветительных работников Сибири и Дальнего Востока.... кадры высшей квалификации работников культурного фронта» (Бурятский пединститут), «вы будете смело нести в народ знания» (республиканская библиотека), «институт станет настоящей кузницей кадров культпросветучреждений восточных регионов» (Министерство культуры Якутской АССР) и др.

В целом, общая оценка происходящего события была высказана следующим образом: «Открытие института в Улан-Удэ - величайшее событие в культурной жизни всей Восточной Сибири», «как новое проявление заботьл Коммунистической партии и Советского правительства о дальнейшем развитии культуры, как большое событие в культурной жизни республики», проявление заботы государства «о культурном росте трудящихся страны»».

Одной из характерных черт стенограммы является наличие в ней автобиографических сведений. Так, И.А. Мохов, в ответном слове на поздравление Ленинградского института культуры останавливается на фактах своей биографии: «Из всех телеграмм меня особенно волнует телеграмма от нашего Ленинградского библиотечного института. Я, товарищи, считаю себя питомием этого института. Мне в свое время не повезло: меня не приняли в этот институт. Это был коммунистический институт, а я не был членом партии, но потом 25 лет тесно связаны с этим институтом. Все мои успехи, достижения были куском этого института».

Несомненный интерес представляет постановляющая часть стенограммы. Директор института Жалсабон предлагает принять письмо в адрес 
ЦК партии и Совета Министров РСФСР. Оно является завершающим акцентом документа, ярким подтверждением атмосферы советской эпохи. Письмо было зачитано заведующим кафедрой А.А. Белоусовым: «Cmyденты, профессорско-преподавательский состав, рабочие и служащче, собрались на торжественное заседание, посвященное открытию первого в Сибири библиотечного института, выражают горячую благодарность Центральному комитету Коммунистической партии Советского Союза, Советскому правительству и его главе Никите Сергеевичу Хрущеву за внимание и заботу о молодежи, ее образовании и воспитании.

Сибирь - в прошлом страна каторги и ссылки - ныне, благодаря героическим усилиям нашего народа, руководимого нашей родной коммунистической партией, превращена в край могучего коммунистического созидания; на огромных ее просторах создаются первоклассные заводы и фабрики, гигантские гидротехнические сооружения, открываются высшие учебные заведения.

Открытие в Улан-Удэ Восточно-Сибирского библиотечного института - большое и радостное событие в культурной жизни не только Бурятской АССР, но и всей Восточной Сибири и Дальнего Востока. Он призван готовить высококвалифицированные кадры библиографов и библиотекарей, руководителей художественной самодеятельности двориов культуры и клубов, полнее удовлетворять все возрастающие духовные запросы намего народа.

Восточно-Сибирский библиотечный институт вошел в строй действующих учебных заведений страны, созданы необходимые условия для учебы и науки.

Заверяем ЦК КПСС и Советское правительство, что задачи в подготовке высококвалифицированных кадров работников культуры коллектив выполнит с честью.

Да здравствует родная Коммунистическая партия! Да здравствует наша великая Родина!».

Организационно-распорядительные, делопроизводственные документы, протокольная документация занимают одно из центральных мест в комплексе источников по истории становления и развития того или иного учреждения. Детальное изучение протоколов и стенограмм позволяет раскрыть широкие возможности их как исторических источников. Важным при исследовании такого рода источников является то, что текст документа представляет собой стенограмму сказанного практически без редактирования. Это преимущество дает возможность погрузиться целиком в процесс события, через каждое слово и фразу представить ушедшее от нас время, мысли, идеи и планы выступающих, а через них понять эпоху, почувствовать атмосферу того времени. Это позволяет говорить о социальнопсихологической составляющей документа как исторического источника.

«Стенограмма торжественного заседания, посвященного открытию Восточно-Сибирского библиотечного института, состоявшегося 30 ноября 1960 г.» как источник обладает высоким информационным потенциалом. Уникальный документ содержит подлинные факты и живую речь участни- 
ков события, которые позволяют сформировать целостное представление о начале деятельности института. Стенограмма вкупе с постановлениями и приказами об организации вуза, может рассматриваться как отправная точка для комплексного воссоздания истории института, в том числе с привлечением и анализом более широкого круга источников.

Изучение такого рода документов, без сомнения, требует решения и ряда источниковедческих задач: сохранение и продолжение традиции стенографирования и ведения в делопроизводстве не только протоколов, но и стенограмм заседаний, особенно ключевых событий (с учетом перехода на аудио-видеозаписи заседаний и постепенной утратой традиционной стенограммы); применение методов сравнительного анализа и привлечения других видов документов при изучении стенограмм, ввиду их субъективности; систематизация комплекса документов по истории ВСБИ-ВСГИКВСГАКИ-ВСГИК, их публикация и введение в научный оборот, чтобы в полном объеме представить все факты, события, оценки и мнения людей.

Таким образом, анализ содержания стенограммы свидетельствует о том, что в рассматриваемый период система отечественного образования находилась под жестким идеологическим контролем, партийные и государственные решения определяли стратегические вопросы развития высшей школы. И в любой исторический период перспективы дальнейшего развития вузов были связаны с необходимостью решения ключевых вопросов: поиск оптимальной организационной структуры, качество профессорскопреподавательского состава, улучшение и постоянная модернизация материально-технической базы и адекватный ответ на потребности регионального рынка труда. В связи с этим, вузы, играя значимую роль в социальноэкономическом развитии территории, должны быть постоянно готовы к вызовам времени и его новым требованиям.

\section{Примечания}

1. Никифоров С. И. Виват, академия! Улан-Удэ : Изд.-полигр. комплекс ВСГАКИ, 2000. 95 с.

2. Перова Е. Ю., Цыремпилова И. С. Исторический опыт подготовки профессиональных кадров для сферы культуры и искусств в региональном вузе // Известия Иркутского гос. ун-та. Серия: История. 2018. Т. 25. С. 106114.

\section{References}

1. Nikiforov S. I. Vivat, akademija! [Vivat, academy!]. Ulan-Ude, 2000. 95 p. [In Russ.].

2. Perova E. Yu., Tsyrempilova I. S. Istoricheskij opyt podgotovki professional'nykh kadrov dlja sfery kul'tury $\mathrm{i}$ iskusstv $\mathrm{v}$ regional'nom vuze [Historical experience of staff training for the sphere of culture and arts in the regional higher educational institution] // Izvestija Irkutskogo gosudarstvennogo universiteta. Serija: Istorija [Bulletin of Irkutsk state university. Series: History]. 2018. V. 25. Pp. 106-114. [In Russ.]. 
DOI 10.31443/2541-8874-2020-3-15-89-99

УДК 378(517.3:571.54)

Базарова О. В., Гомбожапов А. Д.

Bazarova O. V., Gombozhapov A. D.

\section{К ВОПРОСУ О СОТРУДНИЧЕСТВЕ МОНГОЛИИ И РЕСПУБЛИКИ БУРЯТИЯ В СФЕРЕ ВЫСШЕГО ОБРАЗОВАНИЯ \\ TO THE ISSUE OF COLLABORATION OF MONGOLIA AND THE REPUBLIC OF BURYTIA IN THE FIELD OF HIGHER EDUCATION}

В статье рассмотрены основные аспекты сотрудничества между высшими учебными заведениями Монголии и Республики Бурятия на современном этапе. Все представленные в Республике Бурятия вузы имеют тесные связи с образовательными и научно-исследовательскими организациями, с учреждениями культуры и искусства Монголии, позволяющие расширять экспорт образовательных услуг и развивать стратегическое партнерство.

The article considers the main aspects of collaboration between higher educational institutions of Mongolia and the Republic of Buryatia at the present stage. All higher learning institutions functioning in the Republic of Buryatia have close ties with educational and research organizations, cultural and art institutions in Mongolia, which allow to expand the export of educational services and develop strategic partnerships.

Ключевые слова: сотрудничество, высшее образование, Монголия, Республика Бурятия.

Keywords: cooperation, higher education, Mongolia, the Republic of Buryatia.

Республика Бурятия имеет общую границу с Монголией протяженностью в 1213,6 км. Приграничное положение Республики Бурятия предоставляет ей широкие возможности для развития взаимовыгодного сотрудничества.

Бесспорно, что наличие границы - это специфический ресурс, использование которого способствует преодолению периферийности окраинных регионов [3; 4]. В большинстве своем эти регионы характеризуются слабой экономической базой. В связи с этим в исследованиях приграничья и трансграничья основным изучаемым аспектом стали именно внешнеэкономические связи и их роль в развитии региональной экономики. В то же время фактор социальных и этнокультурных особенностей территорий в приграничном сотрудничестве при большом разнообразии российских регионов, безусловно, не мог не стать предметом теоретических и практических исследований $[5 ; 10]$.

Сфера гуманитарного сотрудничества, которая включает в себя целый комплекс вопросов культуры, социально-трудовых отношений, образования и науки, наряду с экономической представляет важную и неотъемле- 
мую составляющую приграничного взаимодействия. От характера и степени развитости гуманитарного сотрудничества напрямую зависит и формирование «пояса добрососедства» на границах Российской Федерации, о намерении укрепления которого неоднократно высказывался и глава МИД РФ Сергей Лавров [14]. Важное значение в укреплении добрососедских отношений представляют вузы приграничных субъектов РФ. Уникальное положение географической и социокультурной близости позволяет им стать активными субъектами в процессе продвижения российской культуры, стандартов образования, русского языка, формировать эффективную площадку межкультурного и межнационального диалога. Кроме того, необходимо подчеркнуть, что вузы - это непосредственные участники регионального экономического развития, которые за счет интернационализации своих образовательных программ и экспорта образовательных услуг готовят уникальных специалистов, владеющих двумя и более языками, способных достойно конкурировать на рынке труда приграничных областей.

Сотрудничество в образовательной сфере Республики Бурятия с Монголией имеет давнюю историю и опирается на многовековой опыт взаимодействия. Это сотрудничество определялось общим руслом взаимоотношений СССР и Монгольского государства. С момента своего образования Монгольская Народная Республика была тесно связана с СССР [11]. Для вступившей на путь всеобщей модернизации Монголии неизбежно вставала проблема отсутствия собственных профессиональных кадров. В августе 1921 года по решению Правительства МНР первая группа студентов, состоящая из 15 монгольских граждан, была отправлена в Москву на учебу в Коммунистический университет трудящихся Востока. Эта дата считается началом партнерства в области образования и культуры между Россией и Монголией.

Большую роль в решении вопроса подготовки национальных кадров сыграла Бурятия. В 30-е гг. прошлого столетия в г. Улан-Удэ действовал рабочий факультет для обучения молодежи из Монголии (Монголрабфак), который осуществил большую работу в деле подготовки кадров для социалистической Монголии [16]. Всего за период его существования с 1930 по 1940 гг. прошли обучение более 400 человек [6]. В середине прошлого столетия в ходе реализации программы индустриализации страны возник острый дефицит квалифицированных кадров для сельского хозяйства и промышленности. В 1952 году между правительством СССР и МНР было заключено соглашение «Об обучении граждан МНР в высших учебных заведениях СССР». В конце 1970-х гг. количество монгольских студентов в вузах СССР насчитывало более 3 тыс. В 1980-е гг. в г. Иркутске обучалось 2000 студентов, в Москве - более 1000 , в Ленинграде - около 800, которые проходили обучение в 287 высших и средних специальных учебных заведениях. Всего за многолетний период сотрудничества в стенах советских и российских учебных заведений прошли обучение свыше 60 тыс. граждан Монголии [17]. В настоящее время в Монголии действует ассоциация «МАВСУЗ Холбоо», которая объединяет монгольских граждан, окончивших учебные заведения СССР и России. Ее усилиями проводятся регулярные встречи выпускников 
и студентов, организуются культурные мероприятия, способствующие становлению и развитию культурно-гуманитарных связей между Монголией и Россией. Так, в сентябре 2019 г. состоялся Форум выпускников советских и российских вузов и молодёжи, который был приурочен к 80-летию совместной победы на Халхин-Голе.

После распада СССР, а вместе с ним всего социалистического лагеря, сотрудничество в сфере образования стало менее интенсивным. В условиях открытости и отказа от идеологических установок изменились и предпочтения монгольских граждан в получении заграничного образования. Монгольская молодежь стала ориентироваться на учебные заведения, располагающиеся в США, КНР, Республике Корея и Японии. По данным Министерства иностранных дел за 2016 год общее количество обучающихся за рубежом монгольских студентов составляло 47132 человек. Из них в долевом соотношении наибольшее количество приходилось на США, затем следует КНР с количеством в 8339 студентов, на третьем месте Республика Корея, в учебных заведениях которой учатся 7396 студентов. Доля монгольских студентов, обучающихся в России, насчитывает 1396 человек [18].

Таблица 1. Количество монгольских студентов, обучающихся в зарубежных высших и средних учебных заведениях по странам

\begin{tabular}{|c|l|c|c|c|}
\hline \multirow{2}{*}{ № } & \multirow{2}{*}{ Страна } & \multicolumn{2}{|c|}{ Количество обучающихся } & \multirow{2}{*}{$\begin{array}{c}\text { Общее } \\
\text { количество }\end{array}$} \\
\cline { 3 - 4 } & & До 18 & От 18 лет & 10,000 \\
\hline \multirow{2}{*}{1} & США & 6,500 & 3,500 & 8,339 \\
\hline 2 & КНР & 415 & 7,924 & 7,963 \\
\hline 3 & Республика Корея & 2,902 & 5,061 & 6,590 \\
\hline 4 & Япония & 1,185 & 5,405 & 2,530 \\
\hline 5 & Канада & 960 & 1,570 & 1,936 \\
\hline 6 & Россия & 112 & 1,824 & 1,692 \\
\hline 7 & ФРГ & 742 & 950 & 1,534 \\
\hline 8 & Великобритания & 634 & 900 & 1,386 \\
\hline 9 & Чехия & 1,300 & 86 & 891 \\
\hline 10 & Казахстан & 148 & 743 & 4,271 \\
\hline 11 & Другие & 310 & 3,961 & 47,132 \\
\hline & Итого & 15,208 & 31,924 & \\
\hline
\end{tabular}

Источник: Номин Г. Монголчууд гадаадын аль оронд очиж суралидаг вэ? [Электронный ресурс] // IKON.MN. - URL: https://ikon.mn/n/u3g.

Надо отметить, что российской стороной в отношении Монголии последовательно проводится политика содействия образовательным контактам и связям между университетами и научно-исследовательскими организа- 
циями, увеличению образовательных квот для монгольских граждан, наращиванию усилий экспорта образовательных услуг. Можно отметить, что в укреплении взаимного сотрудничества в образовательной сфере событием большой значимости стало подписанное 1 июля 2003 г. Соглашение между Правительством Российской Федерации и Правительством Монголии о взаимном признании документов об образовании, ученых степенях и ученых званиях. Также важным шагом в этом направлении стал рост количества образовательных квот для Монголии, по которым предоставляется стипендия на обучение в российских вузах. Если в 2010 году количество квотных бюджетных мест составляло 250, то в 2019 г. оно было доведено до 500 [2].

В настоящее время в российских вузах обучается около 3000 граждан Монголии, что составляет 4\% от общего числа иностранных студентов, получающих высшее образование в России, и является 4-м показателем для стран дальнего зарубежья (после КНР, Индии и Вьетнама) [9, с. 32].

Географическая близость, длительные этнокультурные связи и общность исторических событий выгодно отличают Республику Бурятию среди других российских регионов и являются привлекательными моментами для монгольских граждан при выборе вузов. Развитая сфера высшего образования в Республике Бурятия и признанный высокий уровень подготовки специалистов предоставляют широкие возможности в получении различных востребованных профессий.

Система высшего образования в Республике Бурятия представлена 4 учебными заведениями: ФГБОУ ВО «Восточно-Сибирский государственный университет технологий и управления» (ВСГУТУ), ФГБОУ ВО «Бурятский государственный университет» (БГУ), ФГБОУ ВО «Бурятская государственная сельскохозяйственная академия им. В.Р. Филиппова» (БГСХА им. В.Р. Филиппова), ФГБОУ ВО «Восточно-Сибирский государственный институт культуры» (ВСГИК). В вузах реализуются программы подготовки кадров по 232 направлениям подготовки бакалавров, 12 направлениям подготовки специалистов и по 120 направлениям подготовки магистров.

Из нижеприведенной таблицы видно, что на начало 2017-2018 учебного года количество принятых на обучение монгольских студентов составляло 38 человек, общее количество студентов - 129 и 40 специалистов было выпущено. Для сравнения в 2017-2018 учебном году 450 монгольских выпускников поступили в российские учебные заведения за счет государственной академической стипендии. 
Таблица 2. Иностранные студенты, обучающиеся по программам бакалавриата, специалитета, магистратуры в образовательных организациях высшего образования и научных организациях Республики Бурятия (на начало 2017-2018 учебного года; человек)

\begin{tabular}{|l|c|c|c|}
\hline & $\begin{array}{c}\text { Принято на } \\
\text { обучение }\end{array}$ & $\begin{array}{c}\text { Численность сту- } \\
\text { дентов }\end{array}$ & $\begin{array}{c}\text { Выпущено спе- } \\
\text { циалистов }\end{array}$ \\
\hline $\begin{array}{l}\text { Численность ино- } \\
\text { странных студен- } \\
\text { тов - всего }\end{array}$ & 136 & 398 & 136 \\
\hline $\begin{array}{l}\text { из них граждане } \\
\text { стран: }\end{array}$ & 5 & 12 & 3 \\
\hline Азербайджан & - & 1 & - \\
\hline Армения & - & 1 & - \\
\hline Болгария & - & 1 & - \\
\hline Грузия & - & 1 & - \\
\hline Израиль & - & 3 & 2 \\
\hline Казахстан & - & 1 & - \\
\hline Камбоджа & 1 & 5 & - \\
\hline Киргизия & 78 & 185 & 84 \\
\hline Китай & 38 & 129 & 40 \\
\hline Монголия & - & 2 & - \\
\hline Республика Корея & 3 & 20 & - \\
\hline Таджикистан & 1 & 1 & 1 \\
\hline Туркмения & - & 2 & 4 \\
\hline Турция & 9 & 28 & - \\
\hline Узбекистан & 1 & 5 & - \\
\hline Украина & - & 1 & - \\
\hline Филиппины & - & 5 & \\
\hline
\end{tabular}

Источник: Статистический ежегодник. 2018 г. Статистический сборник / Бурятстат. - Улан-Удэ, 2018. - 482 с.

Было бы неправильным говорить, что основной формой сотрудничества является лишь подготовка монгольских национальных кадров. Все высшие учебные заведения Республики Бурятия имеют хорошо налаженные контакты с образовательными учреждениями и научно-исследовательскими организациями Монголии. Так, ВСГУТУ - один из крупнейших в Сибири технологических вузов, имеющий широкие связи с монгольскими высшими учебными заведениями и научно-исследовательскими институтами. Среди партнеров, с которыми заключены договора о сотрудничестве, находятся ведущие вузы Монголии, такие как Монгольский национальный университет, Монгольский государственный аграрный университет, Международный университет г. Улан-Батор, Институт техники и технологий г. Улан-Батор, Корпорация «Армоно» (научно-экспериментальный центр кожи). Совместно с зарубежными партнерами осуществляется проведение прикладных научно-исследовательских работ, прохождение профессиональных стажировок 
преподавателей, языковых и производственных практик студентов. На базе ВСГУТУ осуществляется подготовка высококвалифицированных научнопедагогических кадров для Монголии через аспирантуру университета [13].

Существенную роль в доступности высшего образования сыграла и организация филиалов. В 2000 году на основе межведомственного протокола приказами Министерства образования России от 01.11.2000 г. № 3154 и Министерства образования, культуры и науки Монголии от 09.01.2001г. № 9 создан Улан-Баторский филиал ВСГУТУ. Подготовка специалистов шла по российским образовательным стандартам с получением диплома государственного образца. В филиале было предусмотрено прохождение образовательных программ студентами в течение 1-2 лет (в зависимости от выбранной специальности) с последующим их переводом в г. Улан-Удэ для завершения обучения на базе ВСГУТУ. В филиале прошли начальный период обучения более 1 тысячи студентов. Это сказалось и на увеличении контингента студентов. Так, в 2014 году в ВСГУТУ обучалось 125 монгольских граждан.

Укреплению образовательных и научных связей содействовала и постоянная организация на базе Монгольского филиала ВСГУТУ разного рода олимпиад, конференций и семинаров в партнерстве с Монгольским национальным университетом, Монгольским государственным университетом, Российским Центром науки и культуры.

Один из ведущих вузов Бурятии - Бурятский государственный университет - наладил широкую сеть партнерств с зарубежными образовательными организациями. Среди монгольских образовательных и научных учреждений соглашение о сотрудничестве подписано с Монгольским государственным университетом, Монгольским государственным университетом образования, Монгольским международным университетом, УланБаторским университетом, Монгольским университетом науки и технологий, с институтами Академии наук Монголии, медицинскими институтами (институт «Новая медицина», Институт традиционной медицины и технологии, Монгольский университет фармацевтических наук) и др. [8]. Благодаря установленным двухсторонним связям студенты университеты имеют возможность выезжать на летние полевые практики в Монголию, проходить стажировку, принять участие в образовательных мероприятиях и проектах. Совместно с монгольскими коллегами проводятся международные конференции, семинары и круглые столы, выполняются научноисследовательские работы по грантам. Выпускники восточного факультета Бурятского госуниверситета работают в системе высшего образования Монголии: Монгольском государственном университете, Монгольском университете образования, Улан-Баторском университете, в Российском экономическом университете им. Г. В. Плеханова, лицейско-университетском комплексе «Их засаг», а также в российских консульствах в гг. Дархан, Эрдэнэт, гостиничных и туристических агентствах, телевизионных компаниях, совместных российско-монгольских предприятиях ГОК, российскомонгольской школе №3 г. Улан-Батор. 
Устойчивыми партнерскими отношениями характеризуются и ведомственные вузы. Бурятская государственная сельскохозяйственная академия им. В.Р. Филиппова, начиная с 60 -х годов прошлого столетия, тесно сотрудничает с Монгольским сельскохозяйственным университетом, с Институтом растениеводства и сельскохозяйственных наук Монгольского сельскохозяйственного университета (г. Дархан). Для преподавателей и студентов предусмотрена возможность краткосрочных стажировок, участие в исследовательских проектах, на базе заключенных договоров ведется подготовка аспирантов, реализуется программа международного обмена [12].

Восточно-Сибирский государственный институт культуры на протяжении длительного времени плодотворно сотрудничает с образовательными организациями и учреждениями науки и культуры Монголии. Институт заключил соглашения и договоры о сотрудничестве с Монгольским государственным университетом культуры и искусств, с Международным университетом «Их Засаг» им. Чингисхана, с Монгольской академией работников искусства, с вузом «Маргад», с Завханским музыкально-хореографическим колледжем, с Государственным музыкально-хореографическим колледжем им. Гончигсумлы г. Улан-Батор и др. [7]. На базе института проводятся курсы повышения квалификации, преподаватели имеют возможность участвовать в программах международного академического обмена. Следует отметить, что среди партнеров присутствуют не только столичные, но и региональные учреждения. Это говорит о достаточно широком географическом присутствии института в образовательном и культурном пространстве Монголии.

Платформой для научно-образовательного сотрудничества являются и академические институты Сибирского отделения, находящиеся в Республике Бурятия (Институт монголоведения, буддологии и тибетологии, Байкальский институт природопользования, Геологический институт, Институт общей и экспериментальной биологии и др.), в которых проходит подготовка кадров высшей квалификации. Большое количество монгольских аспирантов и докторантов представили и защитили диссертации на соискание ученых степеней кандидата и доктора наук.

Перспективы углубления взаимовыгодного сотрудничества обозначаются и в рамках запускаемых в России нацпроектов «Наука» и «Образование». Об этом было заявлено заместителем министра науки и высшего образования Российской Федерации Марины Боровской в ходе встречи с министром образования, науки, культуры и спорта Монголии госпожой Цэдэнбалын Цогзолмаа 19 ноября 2019 г. [15].

Контакты между вузами Республики Бурятия и Монголии укрепляются также благодаря проведению общих культурных и спортивных мероприятий и акций. Так, следует отметить, что регулярно проводятся Слеты монгольских студентов Республики Бурятия, которые организуются силами Генерального консульства Монголии в г. Улан-Удэ совместно с образовательными учреждениями и общественными организациями.

В декабре 2016 года состоялись «Дни Монголии в Бурятском государственном университете», учредителями которого стали Генеральное кон- 
сульство Монголии в г. Улан-Удэ и ФГБОУ ВО «Бурятский государственный университет».

Активная жизненная позиция монгольских студентов, необходимость в координации и взаимопомощи определили потребность в их едином организационном взаимодействии. В 2010 году монгольские студенты ВСГУТУ инициировали создание Ассоциации монгольских студентов Республики Бурятия.

Ярким примером сотрудничества и дружественных отношений стала помощь в сложных условиях распространения эпидемии COVID-19. Бурятский государственный университет принял участие в мероприятиях Правительства Монголии по возвращению граждан Монголии, находящихся за рубежом - студентов высших учебных заведений Москвы, СанктПетербурга, иных российских городов, а также других категорий граждан Монголии. Под руководством Генерального Консульства Монголии в г. Улан-Удэ и Министерства образования РБ университет отработал списки выезжающих, 14 мая 2020 г. организовал централизованный вывоз монгольских студентов на своем транспорте и обеспечил двухразовым питанием [1].

Таким образом, сотрудничество Монголии и Республики Бурятия в сфере образования находится на высоком уровне, все представленные в республике вузы характеризуются устойчивыми партнерским связями с образовательными, научными и культурными учреждениями и центрами Монголии. Каждое высшее учебное заведение имеет свою направленность, позитивный опыт подготовки иностранных студентов и предлагает выпускникам монгольских школ получить качественное образование по востребованным специальностям. Все это позволяет вузам Бурятии расширять экспорт образовательных услуг, тесно взаимодействовать и развивать стратегическое партнерство с учебными заведениями, научными центрами и организациями Монголии.

\section{Примечания}

1. БГУ принял участие в мероприятиях по возвращению студентов Монголии домой // Бурятский государственный университет. URL: http://www.bsu.ru/ news/23048/ (дата обращения: 30.05.2020).

2. В Монголии открыта российская образовательная выставка // ИА REGNUM. URL: https://regnum.ru/news/polit/2591006.html (дата обращения: 30.05.2020).

3. Вагин В. Д. Основа приграничного сотрудничества // Проблемы и перспективы европеизации образования в приграничных территориях : сб. материалов междунар. конф. Псков : Псков. гос. ун-т, 2013. С. 24-28.

4. Вардомский Л. Б. Приграничное сотрудничество на новых и старых границах России // Евразийская экономическая интеграция. 2008. № 1. C. $90-108$.

5. Герасименко Т. И., Лапаева М. Г. Формирование трансграничных регионов как пространственно-временной результат трансграничного взаимодействия // Вестник Оренбургского гос. ун-та. 2012. № 2 (138). С. 298-302. 
6. Дугаржав Л., Филин С. А. Взаимодействие России и Монголии в сфере образования. Улан-Батор : АДМОН, 2012. 300 с.

7. Зарубежные партнеры // Восточно-Сибирский институт культуры. URL: https://vsgaki.ru/international-activities/foreign-partner// (дата обращения: 30.05.2020).

8. Зарубежные партнеры университета // Бурятский государственный университет. URL: http://www.bsu.ru/university/ international/partners/ (дата обращения: 30.05.2020).

9. Индикаторы образования: 2018 : стат. сб. / Н. В. Бондаренко, Л. М. Гохберг, Н. В. Ковалева [и др.] ; Нац. исслед. ун-т «Высшая школа экономики». М. : НИУ ВШЭ, 2018. 400 с.

10. Каганский В. Л. Типы границ и типы районов культурного ландшафта // Культурный ландшафт: теоретические и региональные исследования. Третий юбилейный выпуск трудов семинара "Культурный ландшафт" / отв. ред. В. Н. Калуцков, Т. М. Красовская. М. : Изд-во Моск. ун-та, 2003. C. 20-24.

11. Лиштованный Е. И. От Великой империи к демократии : очерки политической истории Монголии. Иркутск, 2007.

12. Международное сотрудничество // Бурятская государственная сельскохозяйственная академия им. В. P. Филиппова. URL: http://www.bgsha.ru/podrazdeleniya/otdel-mezhdunarodnykhsvyazej/mezhdunarodnoe-sotrudnichestvo.html (дата обращения: 30.05.2020).

13. Международные партнеры // Восточно-Сибирский государственный университет технологий и управления. URL: https://www.esstu.ru/uportal/cooperation/international.htm (дата обращения: 30.05.2020).

14. Россия будет укреплять "пояс добрососедства" у своих границ, заявил Лавров // РИА Новости. URL: https://ria.ru/20190412/ 1552627587.html?rcmd_alg=\&rcmd id =1552627587 (дата обращения: 30.05.2020).

15. Россия и Монголия подтвердили свою заинтересованность в развитии сотрудничества в сфере образования и науки // Министерство науки и высшего образования Российской Федерации : офиц. сайт. URL: https://www.minobrnauki.gov.ru/ru/press-center/card/?id_4=535 (дата обращения: 30.05.2020).

16. Цыремпилов Д. В. Из истории создания и деятельности Монгольского рабочего факультета в г. Верхнеудинск // Государственный архив Республики Бурятия. URL: http://gbu-garb.ru/mongolrabfak (дата обращения: 30.05.2020).

17. Эрдэнэбаяр Г. Взаимодействие России и Монголии в области образования и науки // Вестник РУДН. Серия: Всеобщая история. 2017. № 2. С. 184-193.

18. Номин Г. Монголчууд гадаадын аль оронд очиж суралцдаг вэ? // IKON.MN. URL: https://ikon.mn/n/u3g (дата обращения: 30.05.2020). 


\section{References}

1. BGU prinjal uchastije v meroprijatijakh po vozvrashcheniju studentov Mongolii domoj [BSU participated in the activities to return the Mongolian students home] // Burjatskij gosudarstvennyj universitet [The Buryat state university]. URL: http://www.bsu.ru/news/23048/(30.05.2020). [In Russ.].

2. V Mongolii otkryta rossijskaja obrazovatel'naja vystavka [The Russian educational exhibition has opened in Mongolia] // IA REGNUM. URL: https://regnum.ru/news/polit/2591006.html (30.05.2020). [In Russ.].

3. Vagin V. D. Osnova prigranichnogo sotrudnichestva [Fundamentals of the cross-border cooperation] // Problemy i perspektivy evropeizacii obrazovanija $\mathrm{v}$ prigranichnykh territorijakh : sb. materialov mezhdunar. konf. [Problems and perspectives of education europeanization at the frontier : coll. of the materials of the intern. conf.]. Pskov, 2013. Pp. 24-28. [In Russ.].

4. Vardomskiy L. B. Prigranichnoje sotrudnichestvo na novykh i starykh granicakh Rossii [The frontier collaboration at the new and old borders of Russia] // Evrazijskaja ekonomicheskaja integracija. [The Eurasian economic integration]. 2008. № 1. Pp. 90-108. [In Russ.].

5. Gerasimenko T. I., Lapaeva M. G. Formirovanije transgranichnykh regionov kak prostranstvenno-vremennoj rezul'tat transgranichnogo vzaimodejstvija [Formation of transboundary regions as the space and time results of the transboundary interaction] // Vestnik Orenburgskogo gos. un-ta [Bulletin of Orenburg state university]. 2012. № 2 (138). Pp. 298-302. [In Russ.].

6. Dugarzhav L., Filin S. A. Vzaimodejstvije Rossii i Mongolii v sfere obrazovanija [Interaction of Russia and Mongolia in the field of education]. Ulaanbaatar, 2012. 300 p. [In Russ.].

7. Zarubezhnyje partnery [The foreign partners] // Vostochno-Sibirskij institut kul'tury [East-Siberian institute of culture]. URL: https://vsgaki.ru/international-activities/foreign-partners/ (30.05.2020). [In Russ.].

8. Zarubezhnyje partnery universiteta [The foreign university partners] // Burjatskij gosudarstvennyj universitet [The Buryat state university]. URL: http://www.bsu.ru/university/international/partners/ (30.05.2020). [In Russ].

9. Indikatory obrazovanija: $2018:$ stat. sb. [Indicators of education : 2018 : coll. of articles] / N. V. Bondarenko, L. M. Gokhberg, N. V. Kovaleva [et al] ; National research un-ty «Higher school of Economics]. M., 2018. 400 p. [In Russ.].

10. Kaganskiy V. L. Tipy granic i tipy rajonov kul'turnogo landshafta [Types of borders and types of districts of cultural landscape] // Kul'turnyj landshaft: teoreticheskije i regional'nyje issledovanija. Tretij jubilejnyj vypusk trudov seminara "Kul'turnyj landshaft" [Cultural landscape : theoretical and regional studies. The $3^{\text {rd }}$ jubilee edition of the works of the seminar «Cultural landscape» / chief ed. V. N. Kalutskov, T. M. Krasovskaya. M., 2003. Pp. 20-24. [In Russ.].

11. Lishtovanny Ye. I. Ot Velikoj imperii k demokratii: ocherki politicheskoj istorii Mongolii [From the Great empire to democracy: feature articles about the political history of Mongolia]. Irkutsk, 2007. [In Russ.].

12. Mezhdunarodnoje sotrudnichestvo [International collaboration] // Burjatskaja gosudarstvennaja sel'skokhozjajstvennaja akademija im. V. R. Filippova 
[The Buryat state agricultural academy named after V. R. Filippov]. URL: http://www.bgsha.ru/podrazdeleniya/otdel-mezhdunarodnykhsvyazej/mezhdunarodnoe-sotrudnichestvo.html (30.05.2020). [In Russ.].

13. Mezhdunarodnyje partnery [International partners] // VostochnoSibirskij gosudarstvennyj universitet tekhnologij i upravlenija [East-Siberian state university of technology and management]. URL: https://www.esstu.ru/uportal/cooperation/international.htm (30.05.2020). [In Russ.].

14. Rossija budet ukrepljat' "pojas dobrososedstva" u svoikh granic, zajavil Lavrov [Russia will strengthen «the neighborhood belt» at its borders, Larvov said] // RIA Novosti [RAII News]. URL: https://ria.ru/20190412/1552627587.html?rcmd_alg=\&rcmd_id=1552627587 (30.05.2020). [In Russ.].

15. Rossija i Mongolija podtverdili svoju zainteresovannost' v razvitii sotrudnichestva $\mathrm{v}$ sfere obrazovanija i nauki [Russia and Mongolia have confirmed their interest in the field of education and science] // Ministerstvo nauki i vysshego obrazovanija Rossijskoj Federacii : ofic. sajt [Ministry of science and higher education of the Russian Federation : official site]. URL: https://www.minobrnauki.gov.ru/ru/press-center/card/?id_4=535 (30.05.2020). [In Russ.].

16. Tsyrempilov D. V. Iz istorii sozdanija i dejatel'nosti Mongol'skogo rabochego fakul'teta $\mathrm{v} g$. Verkhneudinsk [From the history of creation and activity of the Mongolian working faculty in Verkhneudinsk town] // Gosudarstvennyj arkhiv Respubliki Burjatija [The state archive of the Republic of Buryatia]. URL: http://gbu-garb.ru/mongolrabfak (30.05.2020). [In Russ.].

17. Erdenebayar G. Vzaimodejstvie Rossii i Mongolii v oblasti obrazovanija i nauki [Interaction of Russia and Mongolia in the field of education and science] // Vestnik RUDN. Serija: Vseobshchaja istorija [Bulletin of RUPF. Series: General History]. 2017. № 2. Pp. 184-193. [In Russ.].

18. Nomin G. Монголчууд гадаадын аль оронд очиж суралцдаг вэ? // IKON.MN. URL: https://ikon.mn/n/u3g (30.05.2020). [In Mong.]. 
DOI 10.31443/2541-8874-2020-3-15-100-116

УДК 378.6(091)(571.54-25)

Арбатская О. А.

Arbatskaya O. A.

\section{ОТ НАУЧНО-ТЕХНИЧЕСКОЙ ИНФОРМАЦИИ ДО ЦИФРОВИЗАЦИИ В ОБРАЗОВАНИИ}

\section{FROM SCIENTIFIC AND TECHNICAL INFORMATION TO DIGITIZATION IN EDUCATION}

Работа посвящена истории становления и развития направления подготовки кадров в области информатизации социально-культурной сферы в Восточно-Сибирском государственном институте культуры. Эта история отражает этапы развития информационного общества в нашей стране: от концепции научно-технической информации до концепции цифровизации на уровне федерального проекта. Прослеживается становление научной и педагогической школы, отмечается инновационная деятельность по внедрению современных информационных технологий в культуре и образовании.

The article is devoted to the history of formation and development of the specialty in the field of informatization of the socio-cultural sphere in East Siberian state institute of culture. This process reflects the stages of the information society development in our country: from the conception of scientific and technical information to that of digitalization at the federal project level. The author traces the formation of the scientific and pedagogical school and notes innovative activities to introduce modern information technology in culture and education.

Ключевые слова: научно-техническая информация, информатика, информационные технологии, информационные системы, социальнокультурная сфера, информационный менеджмент, прикладная информатика, автоматизация библиотек, мультимедиатехнологии, web-дизайн, цифровая экономика.

Keywords: scientific and technical information, Informatics, information technology, information systems, socio-cultural sphere, information management, applied Informatics, library automation, multimedia technologies, web design, digital economy.

Восточно-Сибирский государственный институт культуры (ВСГИК) вписал в свою историю одно из самых инновационных для конца XX века начала XXI века направление образования. В течение 25 лет институт выпускал сначала специалистов для информатизации библиотек, а затем и для других учреждений социально-культурной сферы, востребованных в условиях становления информационного общества, с учетом региональной специфики. Благодаря коллективу преподавателей, осуществляющих подготов- 
ку этих специалистов, институт мог на хорошем уровне обучать новым информационным технологиям будущих специалистов учреждений культуры по всем остальным образовательным программам.

Однако не всем известно, что история становления этого направления образования в нашем вузе началась еще в СССР 38 лет назад. Её участниками было немало сделано для будущих успехов вуза в подготовке специалистов для информатизации учреждений культуры и образования. Данная работа рассказывает об истории становления нового направления подготовки и образования в сфере культуры и уважаемых коллегах, посвятившим себя развитию данного инновационного направления. Эта история отразила этапы развития информационного общества в нашей стране.

Кафедра информатики появилась в нашем институте в 1982 году по инициативе декана библиотечного факультета Ажеевой Раисы Борисовны и при поддержке руководства вуза. Поводом к её созданию явилось стремление не отставать от ведущих вузов культуры, которые создавали кафедры информатики в связи с подготовкой библиотекарей со специализацией «библиотекарь научно-технических библиотек».

Первым заведующим кафедрой был назначен Смирнов Евгений Михайлович, ст. преподаватель кафедры библиографии. В 1968 г. он окончил Ленинградский государственный институт культуры по специальности «Библиотекарь-библиограф» и с 1968 г. по 1985 г. работал преподавателем ВСГИК с перерывом в 1972-1975 гг. на очную аспирантуру ЛГИК. В 1983 году Евгений Михайлович защитил кандидатскую диссертацию на тему «Совершенствование деятельности МТЦНТИ по библиографическому обслуживанию специалистов региона». С 1985 г. Смирнов работал в Омском филиале Алтайского государственного института искусств и культуры доцентом, заведующим кафедрой библиотековедения и библиографии, в 1995 г. был избран профессором кафедры.

В составе первой кафедры информатики работали преподаватели разных дисциплин: Арбатская О.А. - «Технические средства библиотечной работы», Крашневский Н.А. - «Технические средства культурнопросветительной работы», Миткинова Н.М. - «Информатика», Осокина Т.А. - «Математические методы библиотечной работы», Суворов П.С. - «Проблемы современного естествознания». Материально-технической базой кафедры было несколько лабораторий информационной техники: фотолаборатория, студия звукозаписи, лаборатории кинопроекционной техники, аппаратов для чтения микрофильмов и машинописи.

«Информатику» преподавала Миткинова Нелли Моисеевна, выпускница библиотечного факультета МГИК, закончившая аспирантуру Всесоюзного института научно-технической информации (ВИНИТИ). Эта дисциплина содержала в основном теорию информационно-поисковых систем, информационно-поисковые языки, что соответствовало существующей на тот момент концепции информатики, изложенной в монографии «Основы информатики» [6] (1-е издание вышло под заглавием «Основы научной информации»). Термин «информатика» в СССР был несколько иным, чем computer science или аналогичные, используемые в тот период учеными ка- 
питалистических (по терминологии того времени) стран. До этого, согласно определению, данному в Большой Советской энциклопедии, информатика рассматривалась как «дисциплина, изучающая структуру и общие свойства научной информации, а также закономерности ее создания, преобразования, передачи и использования в различных сферах человеческой деятельности».

Однако в это же время, в начале 1980-х годов, в СССР происходило становление информатики как научного направления, связанного с компьютерными науками. Информатика в новом толковании объединяла несколько направлений отечественной науки: кибернетики, прикладной математики и вычислительной техники. В 1982 году вышла монография академика Глушкова В.М. «Основы безбумажной информатики», которая пролила свет на возможности использования ЭВМ в различных областях деятельности.

3 марта 1983 года Постановлением Общего собрания АН СССР на базе четырех институтов: Института прикладной математики им. М.В.Келдыша, Вычислительного центра, Института проблем передачи информации, Ленинградского института информатики и автоматизации образовано Отделение информатики и вычислительной техники и автоматизации (ОИВТ), а в 1984 году был создан государственный комитет по информатике. В 1985 году А. П. Ершовым совместно с группой соавторов был выпущен школьный учебник «Основы информатики и вычислительной техники» (ОИВТ) и началось преподавание информатики как учебного предмета во многих школах Советского Союза. В вузах были созданы кафедры информатики и введена общеобразовательная дисциплина «Информатика», в которой ведущая роль в содержании отводилась программированию.

Новая тенденция изменила профиль деятельности и нашей кафедры. В 1986 году заведующим кафедрой информатики ВСГИК был назначен Баторов Афанасий Раднаевич, выпускник Томского политехнического института по специальности «Автоматика и телемеханика». В 1981 г. он закончил очную аспирантуру Ленинградского электротехнического института, защитил диссертацию на соискание ученой степени кандидата технических наук по теме «Моделирование цифровых вычислительных структур уровня функциональных схем на базе мини ЭВМ».

С этого года дисциплина «Информатика» на библиотечном факультете содержательно изменилась - она соответствовала новой концепции информатики как дисциплины о технологии ЭВМ и программировании. Изучались логико-математические основы ЭВМ, архитектура, компоненты и возможности ЭВМ, области её применения, основы алгоритмизации и построения блок-схем, основы программирования. Однако первые годы основы программирования на нашей кафедре изучались с помощью программируемых микрокалькуляторов; их приобретение для того времени было уже большим достижением.

В конце 1980-х годов ВСГИК получил на основе централизованной поставки советской компьютерной техники компьютерный класс КУВТ готовый комплект учебных персональных компьютеров, объединяемый в локальную сеть. Он был оснащен пользовательским программным обеспечением: текстовым процессором ЛЕКСИКОН, табличным процессором ЛО- 
ТОС, языком программирования БЭЙСИК. Под эту технику был оборудован первый компьютерный класс в нашем вузе - аудитория 300. Были приобретены советские персональные компьютеры «Электроника», принтеры, на которых начиналось внедрение новых информационных технологий в деятельность ВСГИК: первый в вузе сводный расчет часов в электронной таблице, первые электронные тексты различных документов, учебнометодических материалов. Через несколько лет компьютерный класс был оснащен новым поколением персональных компьютеров на основе процессоров IBM-286 с однозадачной операционной системой DOS.

В конце 1980-х годов состав преподавателей кафедры информатики пополнили преподаватели дисциплины «Библиотечные каталоги»: Батуева Э.Б., Бушанова А.Ф., Солодкова Г.С. Такое решение было связано с растущими надеждами на успехи в автоматизации библиотек, которые тогда связывали в основном с созданием электронных каталогов. Но начинали мы с освоения технологии создания баз данных на основе известного тогда программного пакета FoxPro.

Идея подготовки библиотечных кадров, которые могли бы стать специалистами в области автоматизации библиотечно-библиографических процессов, как говорится, «витала в воздухе». Тем более, что к тому времени уже имелся успешный опыт Кемеровского государственного института культуры (КГИК), где в 1979 году на кафедре научно-технической информации под руководством Сбитнева С.А. была создана новая специализация для библиотечной профессии «Технолог АБС».

Поэтому инициативной группой в составе заведующего кафедрой Баторова А.Р., старших преподавателей к.П.н. Арбатской О.А., к.п.н. Батуевой Э.Б. был разработан план функциональной специализации «Технолог АБС», который поддержала декан Р.Б. Ажеева. Первый вариант этого плана соединял в себе комплекс основных специальных дисциплин по традиционной библиотечной технологии и ряд специальных дисциплин функциональной специализации, в том числе по современным программным средствам, например, изучалась технология создания электронных каталогов на базе демонстрационной версии автоматизированной библиотечно-информационной системы (АБИС) MARK. Программы практик и требования к содержанию курсовых работ также соответствовали профилю специализации. Состоялись два выпуска таких специалистов по очной форме в 1994 и 1995 годах и по заочной форме - годом позже. Эти выпускники оказались востребованными преимущественно в самых крупных библиотеках, которые тогда начали создавать электронные каталоги, впоследствии стали незаменимыми специалистами в библиотеках вузов.

В начале 1990-х годов начала формироваться новая концепция информатики как науки об информационных процессах в технических системах, в природе и обществе, в том числе с помощью ЭВМ. Этому способствовало быстрое развитие аппаратных и программных средств, серийный выпуск персональных ЭВМ, которые вскоре стали называть персональными компьютерами (ПК), развитие международного рынка этих средств. Активно разрабатывались и внедрялись автоматизированные информационные 
системы (АИС) на основе баз и банков данных. Стало возможным использовать глобальную вычислительную сеть Интернет: в 1991 году был зарегистрирован отечественный домен $\mathrm{SU}$, а вскоре после образования РФ - еще один домен RU. Кроме того, РФ переживала переход к рыночной экономике и демократизации.

Анализ трудоустройства выпускников тех лет показал, что многие выпускники библиотечного факультета трудоустраиваются в качестве информационных работников, как в государственных, так и в коммерческих структурах, на местах, требующих хотя бы минимальной подготовки пользователей персональных ЭВМ в сочетании с документоведческой подготовкой. Наличие регионального спроса на информационные кадры, а также представленная возможность разрабатывать и внедрять экспериментальные учебные планы предопределили появление новых направлений подготовки специалистов в области информационного обслуживания.

По инициативе к.П.н. Бурловой Е.Н., которая тогда была заведующей кафедрой библиотековедения, при поддержке Р.И. Пшеничниковой, проректора по учебной и воспитательной работе, была создана инициативная рабочая группа, в которую вошли: Арбатская О.А., декан информационногуманитарного факультета, Баторов А.Р., зав. кафедрой информатики, доцент кафедры информатики Батуева Э.Б. За короткий срок была проделана огромная работа по разработке двух образовательных программ и учебных планов. Разработчики экспериментальных учебных планов создали модели специалистов нового профиля, основанные на современном представлении об информационной среде социально-культурной сферы [1].

Программа специализации «Технолог АИС» (Баторов А.Р., Арбатская О.А., Батуева Э.Б.) сочетала программно-техническую подготовку и обучение технологии аналитико-синтетической переработки информации. Предусматривалось изучение методов структурирования баз данных, проектирования АИС, создания информационных продуктов и услуг, соответствующих запросам потребителей информации. Предполагались квалификации: технолог АИС, системный аналитик АИС, администратор АИС.

Программа специализации «Организатор информационного маркетинга» (Бурлова Е.Н., Баторов А.Р.) включала наряду с программнотехнической подготовкой и технологией обработки документов экономическую и правовую подготовку, углубленное изучение китайского, турецкого и английского языков, психологии общения, риторики, а также методики информационного маркетинга. Предполагаемые квалификации: менеджер информационного маркетинга, менеджер информационных систем.

Первый набор по новым планам состоялся в 1992 году. Впоследствии эти экспериментальные планы были приведены в соответствие государственному образовательному стандарту по специальности 071900 «Информационные системы в социально-культурной сфере».

Реализация планов подготовки специалистов нового направления потребовала значительных усилий по разработке методического обеспечения дисциплин, курсовых работ и практик. Оба плана предусматривали изучение архитектуры АИС, современных методов и средств программирования, 
создания и администрирования компьютерных сетей, поэтому в кадровый состав кафедры были приняты молодые специалисты по вычислительным системам и сетям, выпускники Восточно-Сибирского технологического института: Дегтярёв С., Баторов П., Хорват И.

Поиски партнеров в организации баз практик, заказчиков на выполнение курсовых и дипломных работ способствовали развертыванию инновационной деятельности коллектива кафедры не только в учреждениях социально-культурной сферы, но и в самом вузе. С 1992 года кафедра принимала участие в инновационных проектах по автоматизации библиотек региона. А.Р. Баторов, О.А. Арбатская, Э.Б. Батуева являлись соавторами, консультантами и исполнителями инновационных проектов внедрения новых информационных технологий в библиотеке ВСГАКИ, Бурятской Республиканской библиотеке, Государственной республиканской юношеской библиотеке. Проект «Внедрение новых информационных технологий в деятельность учреждений культуры Республики Бурятия» получил грантовую поддержку Правительства республики.

1995 год оказался для нашего вуза богатым на масштабные преобразования и события. Ректором ВСГИК была избрана Р.И. Пшеничникова. ВСГИК был реорганизован в Восточно-Сибирскую государственную академию культуры и искусств (ВСГАКИ). Были открыты региональные факультеты ВСГАКИ в Республике Саха (Якутия) и Республике Тыва. О.А. Арбатская приняла участие в создании регионального факультета ВСГАКИ в Кызыле, А.Р. Баторов и Э.Б. Батуева - в Якутске. На обоих факультетах было создано актуальное для республик Тыва и Саха направление подготовки по специальности «Информационные системы в социально-культурной сфере», причем наборы осуществлялись на внебюджетной основе. Впервые для Восточной Сибири началась подготовка кадров по специальности, потребность в которой в условиях начального этапа информатизации во всех сферах деятельности и перехода к рыночной экономике была чрезвычайно актуальной.

На базе кафедры информатики приказом ректора № 199/1 от 4.10.1995 г. был создан новый факультет менеджмента информационных технологий (МИТ). Деканом был назначен А.Р. Баторов. В составе факультета созданы новые выпускающие кафедры: автоматизированных информационных систем (АИС), маркетинга и менеджмента информационной деятельности (ММИД).

На должность первого заведующего кафедрой АИС был приглашен к.ф.-м.н., доцент Дармаев Тумэн Гомбоцыренович, который закончил в 1982 году математический факультет Новосибирского государственного университета (НГУ), в 1986 г. - очную аспирантуру НГУ, защитил диссертацию на тему «Методы построения адаптивных разностных сеток». Дармаев Т.Г. работал в 1986-1990 гг. младшим научным сотрудником НГУ, в 1990-1992 гг. - научным сотрудником Института теоретической и прикладной механики СО АН СССР; в 1992-1994 гг. - старшим преподавателем кафедры высшей математики Бурятского филиала НГУ, в 1994 г. - заведующим кафедрой информатики БФ НГУ. В 1995-1999 гг. был заведующим кафедрой АИС ВСГАКИ. В 1999-2002 гг. - заведующим геоинформационным центром БИП 
СО РАН, в 2002 г. - исполнительный директор Бурятского центра информатизации Байкальского региона, с 2005 года - Научно-образовательного и инновационного центра системных исследований и автоматизации БГУ. Имеет звание «Почетный работник высшего профессионального образования РФ».

Кафедра АИС обеспечивала подготовку по общепрофессиональным и специальным дисциплинам для специализации «Технолог АИС». В первом её составе работали доценты: Арбатская О.А., Баторов А.Р., Батуева Э.Б., Дармаев Т.Г., совместителем - специалист по экспертным системам к.ф.м.н. Занданова Г.И. (БНЦ СО РАН); позже - приняты молодые специалисты: Ринчинова С.Е. (МГИК, библиотекарь-библиограф) и Урбаханов А.В. (БГПИ, математик).

Заведующей кафедрой ММИД стала к.п.н., доцент Бурлова Елена Николаевна. В 1975 году она закончила библиотечный факультет ВСГИК, работала в научно-методическом отделе Бурятской Республиканской научной библиотеки. В 1987 году закончила очную аспирантуру МГИК, защитила диссертацию на соискание ученой степени кандидата педагогических наук. С этого года работала преподавателем, старшим преподавателем, заведующей кафедрой библиотековедения ВСГИК; заведующей кафедрой ММИД (1995-2001); деканом факультета МИТ (2001-2006), директором Института экономики, управления и информационных технологий (2006-2008), доцентом кафедры УИРС (2008-2012). Имеет звания: «Заслуженный работник культуры Республики Бурятия» и «Почетный работник высшего профессионального образования РФ».

Кафедра ММИД обеспечивала подготовку по экономике, менеджменту и маркетингу, а также дисциплинам специализации «Организатор информационного маркетинга». В первом составе кафедры работали Бурлова Е.Н., Кургузова 3.С., Занданов Б.И., Ландо Б.Б. Приглашена с кафедры экономики БГСХА опытный педагог к.э.н. Алексеева Ф.А.

На факультете сохранилась и кафедра информатики, но уже в новом качестве - вузовской, обеспечивающей по дисциплинам математика и информатика, в том числе для образовательных программ подготовки менеджеров и экономистов.

Заведующей кафедрой информатики была назначена к.п.н., доцент Арбатская Ольга Александровна. В 1973 году она закончила Иркутский государственный университет по специальности физика; работала учителем в одной из школ г. Иркутска. С 1977 года стала преподавателем кафедры кинофотомастерства, затем - библиотековедения, а в 1982 году - кафедры информатики ВСГИК. В 1986 году закончила очную аспирантуру ЛГИК, защитила диссертацию на тему «Влияние структуры текста на выбор формализованного метода библиографического анализа» и вернулась на кафедру информатики ВСГИК. В 1992-1995 гг. работала в должности декана информационно-гуманитарного факультета ВСГИК, в 1995-2000 гг. - доцента кафедры АИС и заведующего кафедрой информатики ВСГАКИ. С 2000 по 2010 гг. работала доцентом на кафедре информатики Санкт-Петербургской государственной академии культуры и искусств. С 2010 года - доцент ка- 
федры информационно-коммуникационных технологий (ИКТ) ВСГАКИ, в 2016-2018 гг. - заведующая кафедрой ИКТ, с 2018 года - доцент кафедры библиотечно-информационных ресурсов ВСГИК. Имеет звание «Заслуженный работник культуры Республики Бурятия».

На этой кафедре начинали трудовую деятельность молодые специалисты Гармаева О.В. (БГПИ) - ныне доцент кафедры прикладной информатики БГСХА, и первые выпускники Ашатуева (Доржиева) Э.С. (технолог АБИС), Горохова Т.В. (технолог АИС), с 1997 года - Цыренжапов Н.Б. (БГПИ, математик) Были приглашены опытные программисты-математики Климентьева Л.Г., Сяськина Н.Г.

В 1996 году ВСГАКИ получил лицензию на учебные планы двух квалификаций: «Информатик-технолог» и «Менеджер информационных систем» по специальности 071900 «Информационные системы в социальнокультурной сфере», состоялся первый выпуск новых специалистов. По этой специальности было сделано 5 выпусков по очной форме, несколько выпусков по заочной форме, в том числе - первые группы из региональных филиалов в Тыве и Саха-Якутии. В 2000 году также состоялся первый выпуск экспериментальной группы, обучающейся по целевому набору на заочном обучении в ускоренные сроки (так называемые «ускоренники»). Такой набор стал возможен в результате целенаправленной работы Батуевой Э.Б., Бурловой Е.Н. по организации двухуровневой системы подготовки кадров. Были налажены связи и заключены договоры о целевых местах для лучших выпускников колледжей и лицеев с профильными специализациями.

На факультете своими силами проводились масштабные работы по развитию программно-технической базы вуза. Созданы новые компьютерные классы, локальная компьютерная сеть факультета, интернет-сервер и первые веб-страницы академии. Для ведения электронного делопроизводства и обслуживания имеющейся техники потребовалось ввести должности техников ЭВМ, на которых работали наши же студенты. Изменения произошли не только в техническом обеспечении деятельности факультета, но и в учебно-методическом. Для преподавателей и студентов в помощь организации научно-исследовательской и самостоятельной работы был открыт кабинет информатики с современной научной, методической литературой и периодическими изданиями по информатике, программированию, информационному маркетингу, менеджменту. Заведующей кабинетом почти 20 лет проработала Д.Б. Цыренова.

В этот период были заложены основы педагогической и методической школ новых направлений подготовки: от методики преподавания дисциплин базового блока и специализаций до моделей курсовых работ, практик, дипломных работ. В этих моделях был заложен принцип выполнения практико-ориентированных проектов в русле инновационной деятельности кафедр. С целью поддержки разработок студенческих проектов была создана учебная лаборатория «Инфомаркет» под руководством Бурловой Е.Н. Для разработки некоторых проектов на базе лаборатории создавались временные трудовые коллективы, например, проект создания справочника «Желтые страницы Улан-Удэ» (Путилин Д., Холявко С.) стал сначала до- 
черним предприятием, а впоследствии - самостоятельным предприятием. Факультет в этот период активно приобретал новых партнеров, предлагая для апробации различные инновации на основе создания баз данных, автоматизированных информационных систем (АИС), автоматизированных рабочих мест (AРМ). Преподаватели кафедры АИС совместно со студентами разрабатывали и внедряли проекты для учреждений культуры и социальнокультурной сферы. Одним из первых внедренных проектов была АИС «Аптечная сеть Улан-Удэ» (Поплаухин В., Самокрутов Р.).

Факультет МИТ стал форпостом внедрения новых информационных технологий (НИТ) в академии. Была внедрена созданная под руководством А.Р. Баторова АИС «Абитуриент», которая использовалась более 15 лет. В 1996 году был создан информационный центр ВСГАКИ, первыми сотрудниками которого стали наши выпускники. Жанчипова С.З. до сего времени работает документоведом. В деканатах и отделах установлены компьютеры, и появилась необходимость обучения сотрудников - этим занималась кафедра информатики. Были организованы курсы пользователей ПК для сотрудников академии, разработан курс «Информационная культура» для аспирантов, а также краткосрочные коммерческие курсы пользователей.

Проект «Внедрение новых информационных технологий в деятельность учреждений культуры Республики Бурятия» стал комплексной темой факультета и получил свое дальнейшее развитие. По инициативе и с участием Арбатской О.А. и Баторова А.Р. был создан отдел автоматизации в Республиканской библиотеке, которая с 1992 года начала создание электронного каталога. Учебно-исследовательская лаборатория «Технолог» способствовала внедрению пакета «Библиотека 4.0» (разработчик АО «Библиотечная компьютерная сеть» МГУ) в библиотеки всех вузов Республики Бурятия, разрабатывались проекты корпоративной каталогизации вузовских библиотек, «Библиотечная компьютерная сеть РБ». В научную библиотеку ВСГИК была распределена Путинцева Н. (технолог АБС) и под руководством Батуевой Э.Б. началось создание электронного каталога в АБИС «Библиотека 4.2». Большой вклад в автоматизацию нашей библиотеки внесла Алдарова М.M., которая около 20 лет была технологом АБИС ИРБИС.

Результаты разработок по комплексной теме «Внедрение новых информационных технологий в деятельность учреждений культуры республики Бурятия (1995-2000 гг.) нашли отражение в сборнике материалов региональной научно-практической конференции «Новые информационные технологии в культуре и образовании» [7], проведенной ВСГАКИ по гранту совместно с Министерством культуры РФ 26-30 июня 2000 года.

Масштабные работы по информатизации во всех областях деятельности в начале 2000-х годов требовали подготовки соответствующих кадров, что объясняет появление в российском классификаторе специальностей «Прикладной информатики» по областям применения. Реформы в социально-экономической жизни, образовании и информатизации региона определили потребность в кадрах, способных внедрять новые информационные технологии в социально-культурной сфере. Эти факторы определили переход от специальности «Информационные системы» к новой специальности 
080801 «Прикладная информатика в СКС». На факультете были разработаны две специализации по этой специальности: «Мультимедийные технологии и web-дизайн» (Э.Б. Батуева - кафедра АИС), в связи с актуальностью освоения веб-технологий и мультимедиа, и «Информационные системы в бизнес-реинжиниринге» (Е.Н. Бурлова, Ф.А. Алексеева - кафедра ММИД), в связи с тенденцией системной реорганизации деятельности предприятий при внедрении АИС.

В 2002 году факультет МИТ возглавила кандидат педагогических наук, доцент Е.Н. Бурлова. К 2003 году на факультете были сформированы две кафедры, выпускающие по специализациям: информационнокоммуникационных технологий (ИКТ) - «Мультимедийные технологии и web-дизайн» и управления информационными ресурсами и системами (УИРС) - «Информационные системы в бизнес-реинжиниринге».

Заведующей кафедрой ИКТ назначена Батуева Эвелина Батуевна. В 1972 она году закончила библиотечный факультет ВСГИК со специализацией «Библиотекарь-библиограф научных библиотек», в 1977 году - очную аспирантуру ЛГИК, в 1983 году защитила диссертацию на соискание ученой степени кандидата педагогических наук. Работала преподавателем кафедры библиотековедения ВСГИК, а с 1983 года - заместителем декана по заочному обучению. С 1988 года перешла на кафедру информатики, в 1993 году стала доцентом кафедры информатики, в 1995 году - кафедры АИС. Имеет почетные звания: «Отличник культуры Республики Саха (Якутия)» «Заслуженный работник образования Республики Бурятия», награждена нагрудными знаками «За достижения в культуре», «Почетный работник высшего профессионального образования Российской Федерации».

Преподавателями кафедры ИКТ были в основном молодые специалисты: выпускники ВСГУТУ Базархандаев Д.В., Токмаков Д.И., Тулонов Н.К., Федотов В.В., выпускники ВСГАКИ Дондупова Э.С., Тутубалин В.А., Цыденова О.М., Шактамаева Л.В., Шевляков А.И.

Заведующей кафедрой УИРС стала Алексеева Федосья Алексеевна, которая с 2002 года возглавляла кафедру ММИД. В 1970 году она окончила Бурятский государственный сельскохозяйственный институт (БГСХИ), работала главным экономистом совхоза. После окончания аспирантуры Ленинградского сельскохозяйственного института и защиты диссертации на соискание ученой степени кандидата экономических наук в 1979 году работала преподавателем кафедры экономики БГСХИ. В 1996 году приглашена на должность доцента кафедры ММИД ВСГИК, с 2001 года занимала должность заведующей кафедрой УИРС, в 2009-2013 гг. работала доцентом кафедры ИКТ. Награждена нагрудным знаком «Почетный работник высшего профессионального образования Российской Федерации».

Преподавателями кафедры УИРС были опытные педагоги: доценты Алексеева Ф.А., к.э.н., Бурлова Е.Н., к.П.н., уже состоявшиеся старшие преподаватели Сяськина Н.Г., Ренчинова С.Е., Цыренжапов Н.Б. и молодые преподаватели, выпускники БГУ Бурдуковская Ю.В., Хогоев И.А. и ВСГАКИ - Казачков М.А., Целовальникова Е.В. 
В таком составе факультет МИТ просуществовал до 2006 года. Эти годы отметились самыми большими выпусками по очной, заочной и ускоренной формам обучения. Была создана действенная система многоуровневой подготовки специалистов: НПО-ССУЗ-ВУЗ, налажены контакты с учреждениями культуры, здравоохранения, образования, библиотеками высших учебных заведений, которые нуждались во внедрении новых информационных технологий.

Продолжена традиция активной инновационной деятельности на основе студенческих проектов информатизации библиотек, музеев и других учреждений социально-культурной сферы, что позволило выпускать востребованных на рынке труда специалистов. В учебно-творческой лаборатории «Инфомаркет» под руководством к.э.н. доцента Алексеевой Ф.А. разрабатывались студенческие проекты АИС поддержки принятия управленческих решений. Учебно-творческая лаборатория «Технолог» под руководством к.П.н., доцент Батуева Э.Б. взяла курс на проекты, соответствующие новой специализации: разработка мультимедийных справочников, web-сайтов («Звуки Евразии: международный фестиваль традиционной музыки»), разработок для академии («Система управления дистанционным обучением в ФГОУ ВПО ВСГАКИ»).

В этот период продолжала развиваться научная школа факультета, что позволило вырастить «свои» научно-педагогические кадры. Была заложена традиция апробации научно-инновационной деятельности студентов. Опубликованы сообщения в сборнике научных работ студентов ВСГАКИ «Культура: История и современность глазами студентов» 2003 г. Совместно с Российским фондом фундаментальных исследований, БНЦ СО РАН, БГУ, Иркутским научным центром, Институтом динамики систем и управления СО РАН в 2003 году проведена конференция «Инфокоммуникационные и вычислительные технологии и системы» и выпущен научный сборник [4].

Молодые преподаватели и сотрудники - выпускники факультета Баторова Е.М., Будаева О.В., Будаева Э.В., Мисникова Н., Аюшиева Е.Б., Дондупова Э.С., Манжуева (Цыденова) О.М., Казачков М.А., Сапунова А.Ф., Ульзетуева Д.Д., Целовальникова Е.В., Шактамаева Л.В., Шевляков А.И., а также выпускники ВСГУТУ Токмаков Д.И., Федотов В.В. обучались в очной и заочной аспирантурах города Москвы, Улан-Удэ, Красноярска, СанктПетербурга, успешно занимались научной и преподавательской деятельностью.

Защитили кандидатские диссертации на соискание ученой степени кандидатов физ.-мат. наук Н.Б. Цыренжапов, А.В. Урбаханов, культурологии - С.Е. Ренчинова, исторических наук - Л.Ц. Алексеева, экономических наук - Е.Б. Аюшиева, философских наук - О.М.Манжуева.

Блестящую научную карьеру сделала Манжуева O.M. - выпускница 1998 года по специализации «Технолог АИС» защитила в 2005 году диссертацию по специальности 09.00.11 «Социальная философия», на тему «Философско-этические основания информационной безопасности», а в 2017 году - докторскую диссертацию по специальности 09.00.08 «Философия науки и 
техники» на тему «Философская парадигма информационной безопасности».

В начале 2000-х годов на факультете МИТ была создана инженернотехническая служба (Кржановский А.Ф., Федотов В.В.), которая обслуживала интернет-сервер, локальную сеть факультета, парк компьютеров и периферийных устройств, обеспечивала дистанционное обучение со студентами Тувинского филиала. В 2004 году на основе этой службы был создан Центр информационных технологий академии, в состав которого вошли и специалисты работающего с 1996 года информационного центра. Возглавил Центр старший преподаватель кафедры ИКТ Токмаков Д.И. Центр взял на себя ответственность за информатизацию учебного процесса и управления вузом, объединение, развитие и сопровождение единой компьютерной сети вуза.

Факультет менеджмента информационных технологий просуществовал до 2006 года. За годы своего существования факультет подготовил 10 выпусков и дал Восточно-Сибирскому региону почти 1000 специалистов. Многие из них являются руководителями и ведущими специалистами центров информационных технологий (Путилин Д., Холявко С., Мисникова Н., Самокрутов Р., Никифоров А., Баженов А., Дамбаев М., Бадмаев А., Смирнов Е., Бальжанова А., Вологжанина О., Ульзетуева Д.Д., Горохова Т.В., Абарыкова Л.В., Чеботарев П.С., Рассохина В.Н. и др.). Большинство выпускников работает в своем регионе (Республиках Бурятия, Тыва и СахаЯкутия, гг. Иркутск, Чита), некоторые нашли свое место в других городах (Москва, Санкт-Петербург и др.). Горохова (Семёнова) Т.В. (1997) - заместитель директора по дистанционным образовательным технологиям Центра детско-юношеского технического творчества и информационных технологий Пушкинского района г. Санкт-Петербурга. Чеботарев П.С. (2000) - директор IT департамента по Восточному Полигону «ЛокоТех» г. Иркутск. Воложанина О.А. (2001) начала карьеру с программиста научной библиотеки Бурятского государственного университета, ныне - заместитель директора библиотеки по информатизации.

Выпускники факультета были востребованы в учреждениях социально-культурной сферы: библиотеках, музеях, отделах информационных технологий районных, городских администраций, предприятий; а также - в школах, колледжах и вузах в качестве преподавателей информатики и специалистов информационных центров. Ульзетуева Д.Д. (2002), начав с работы специалиста информационно-аналитического центра Северо-Западного института управления Российской академии народного хозяйства и государственной службы при Президенте Российской Федерации (г. СанктПетербург), закончила аспирантуру, защитила диссертацию на соискание ученой степени кандидата технических наук, работает доцентом кафедры бизнес-информатики, математических и статистических методов в этом же институте. Отбоева С.Д. (2004) - к. социол. н., доцент кафедры «Системы информатики» ВСГУТУ.

Выдающуюся карьеру сделала Перова Е.Ю. Она закончила ВСГАКИ по специальности «Информационные системы в СКС», работала сотрудником, затем руководителем Центра заочного и дополнительного образования, 
защитила диссертацию на соискание ученой степени кандидата экономических наук, с 2015 года исполняла обязанности ректора ВСГИК, в 2019 году избрана на должность ректора.

В нашем вузе на ответственных должностях работают и другие выпускники: Ануева И.В. - руководитель Центра заочного и дополнительного образования, Нетребина Л.А. - начальник общего отдела ВСГИК.

Период с 2005 года отличается чередой преобразований кафедр и факультетов. Под влиянием тенденций тех лет 16 декабря 2006 года на базе факультета МИТ и факультета бизнеса и администрирования в СКС был создан институт экономики, управления и информационных технологий (ИУЭИТ), объединивший укрупненную группу специальностей: экономика, менеджмент, вычислительная техника. Институт возглавила Е.Н. Бурлова. В составе ИУЭИТ инновационная деятельность кафедр ИКТ и УИРС в процессе подготовки специалистов новых профилей обогатилась за счет плодотворного сотрудничества с другими направлениями подготовки.

В декабре 2008 года произошла очередная реорганизация. В состав института вошла кафедра библиотечно-информационных ресурсов (БИР), ИЭУИТ был переименован в Институт информационных технологий, экономики и управления (ИИТЭУ). Его возглавил Урбаханов А.В., к.ф.-м.н., доцент кафедры ИКТ, который на тот момент занимал должность заместителя директора ИЭУИТ. Его трудовая биография началась в 1997 году после окончания БГПИ на кафедре АИС. С 1999 по 2001 гг. он выполнял обязанности заведующего кафедрой, в 2003 году окончил очную аспирантуру ВСГУТУ, в 2005 году защитил диссертацию, в 2008 году возглавил ИИТЭУ, в 2011-2015 гг. - институт культурного наследия и информационных технологий (ИКНИТ).

В 2009 году кафедры ИКТ и УИРС были объединены в кафедру ИКТ, которую возглавила Э.Б. Батуева. В составе преподавателей тех лет были как опытные специалисты высшей школы, доценты Алексеева Ф.А., Батуева Э.Б., Бурлова Е.Н., Убонов А.В., Урбаханов А.В., Цыренжапов Н.Б.; старшие преподаватели Алексеева Л.Ц., Банзаракцаев Ю.Н., Сяськина Н.Г., так и молодые ст. преподаватели: Манжуева О.М., Сапунова А.Ф., Севергина Ю.В., Токмаков Д.И., Тулонов Н.К., Тутубалин В.А., Федотов В.В., Целовальникова Е.В., Шактамаева Л.В., преподаватели Дондупова Э.С., Казачков М.А., Столбовский С.В., Шевляков А.И.

Казачков М.А., выпускник по специализации «Организатор информационного маркетинга», работал преподавателем на кафедрах УИРС, ИКТ, экономики; в настоящее время работает в ЦИТ специалистом технической поддержки информационно-коммуникационных систем.

Благодаря профессионализму ППС кафедра могла выполнять договорные проекты и разработки по формированию электронных коллекций и справочников, созданию мультимедийных продуктов, проведению маркетинговых исследований и др. работы для учреждений социально-культурной сферы и производства. Преподаватели кафедры под руководством Батуевой Э.Б. приняли активное участие в различных грантах и проектах как академического, так и международного уровня. Наиболее крупными из них явля- 
ются проекты, руководителем которых был к.ф.-м.н., доцент кафедры, проректор по учебно-воспитательной работе ВСГАКИ Цыренжапов Н.Б., по грантам Российского Фонда Фундаментальных научных исследований: семинар молодых ученых в рамках III Международной конференции «Инфокоммуникационные и вычислительные технологии и системы» [3]; Международный проект «Древо культуры» Россия - Монголия - Южная Корея и семинар молодых ученых «Информационные технологии и традиционная кочевая культура: проблемы взаимодействия» [5].

Преподаватели и студенты активно участвовали в научнопрактических конференциях вузовского, межвузовского, республиканского уровня, а также на международном уровне по различным аспектам экономики, информационных технологий. Большая часть разработок выполнялась в рамках комплексной темы кафедры «Создание мультимедийных ресурсов об объектах природного и культурного наследия Бурятии».

Результатом очередных преобразований структуры ВСГАКИ в 2011 году стало образование института культурного наследия и информационных технологий - ИКНИТ, в состав которого вошли кафедры: ИКТ, библиотечно-информационных ресурсов, музейного дела и культурного наследия, директором был избран Урбаханов А.В.

Один из самых драматических моментов высшего образования в нашей стране - переход на уровневую систему высшего профессионального образования (ВПО) и федеральный государственный образовательный стандарт (ФГОС) ВПО пришелся на долю нового заведующего кафедрой ИКТ, нашей выпускницы Шактамаевой Л.В. В 2000 году она закончила ВСГАКИ по специальности «Информационные системы в СКС». С 2003 года работала преподавателем, затем старшим преподавателем кафедры ИКТ, с 2011 по 2016 гг. выполняла обязанности заведующего кафедрой. В настоящее время совмещает работу специалиста по менеджменту качества и преподавательскую деятельность.

Профессорско-преподавательский состав кафедры составляли доценты: проректор по учебной работе к.ф.-м.н. Цыренжапов Н.Б., директор ИКНИТ к.ф.-м.н. Урбаханов А.В., к.п.н. Батуева Э.Б., к.п.н. Арбатская О.А., к.т.н. Убонов А.В., к.филос.н. Манжуева О.М., к.э.н. Аюшиева Е.Б., старшие преподаватели Дулгаров А.Я., Федотов В.В., Целовальникова Е.В., Дондупова Э.С.

Дулгаров А.Я., выпускник по специализации «Технолог АИС», в 2010 году защитил диссертацию на соискание ученой степени кандидата культурологии, работал ст. преподавателем кафедры ИКТ и декоративноприкладного искусства (ДПИ), с 2013 г. - доцент, заведующий кафедрой ДПИ.

В 2011 году кафедра ИКТ перешла на утвержденный ФГОС ВПО подготовки бакалавров по направлению подготовки 230700 «Прикладная информатика» с профилем «Дизайн». Заведующая кафедрой Шактамаева (Миронова) Л.В. с участием Батуевой Э.Б. и Арбатской О.А. энергично взялась за разработку образовательной программы бакалавриата. 
В новой образовательной программе были учтены современные тенденции развития и внедрения цифровых технологий в социальнокультурной сфере - стремительное развитие мультимедиа и сетевых услуг на основе веб-сервисов. При этом сохранена специфика, отличавшая программу ВСГИК по специальности «Прикладная информатика»: серьезная математическая и программно-техническая подготовка, проектный подход в организации курсовых работ и практик, выпускных квалификационных работ.

Областью профессиональной деятельности бакалавра прикладной информатики с профилем «Дизайн» было определено проектирование и внедрение информационных систем и технологий в различных сферах, а также дизайн-проектирование мультимедиа и печатной продукции, webдизайн. Вторая версия ФГОС ВПО «Прикладная информатика» потребовала переработки образовательной программы и учебного плана, и с 2014 года кафедра ИКТ осуществляла подготовку бакалавров по направлению подготовки 09.09.00 «Прикладная информатика» с профилем «Информационный дизайн».

Были подготовлены 4 выпуска бакалавров наборов 2011-2015 гг. Сложность этого периода заключалась в одновременном обучении и бакалавров, и специалистов. Так в 2015 и 2016 гг. выпускались и бакалавры, и специалисты, группы Тувинского и Читинского филиала. Тематика выпускных работ студентов заочного отделения отражала растущие потребности учреждений культуры региона в специалистах, способных проектировать, создавать, эксплуатировать корпоративные web-сайты, разрабатывать рекламные информационные продукты на основе современных цифровых технологий, использовать онлайновые сервисы.

Кафедрой были организованы и успешно проведены в 2013 и 2014 годах республиканские олимпиады по математике (председатель оргкомитета - к.ф.-м.н., доцент Цыренжапов Н.Б.) и программированию (председатель оргкомитета - к.ф.-м.н., доцент А.В. Урбаханов). Наши студенты принимали активное участие в межвузовских, всероссийских олимпиадах по информатике, математике, экономике, маркетингу, менеджменту, гуманитарным дисциплинам; занимали призовые места.

Профессорско-преподавательский состав кафедры информационнокоммуникационных технологий ежегодно принимал активное участие в научных конференциях разного уровня. Темы докладов и публикаций студентов и преподавателей [2], выпускных квалификационных работ бакалавров, посвященных актуальным проектам созданию и интеграции информационных ресурсов об объектах природного и культурного наследия региона, внедрению ЭИОС в вузе, говорят об инновационном характере научной деятельности студентов и преподавателей кафедры ИКТ.

В 2015 году ВСГАКИ вновь становится институтом культуры ВСГИК. Кафедра ИКТ в результате реорганизации структуры вуза оказывается в составе гуманитарно-информационного факультета (ГИФ), заведующей кафедрой в 2016 году назначается Арбатская О.А. 
В 2017 году был опубликован национальный проект «Цифровая экономика РФ». В обиход вошли новые термины: «цифровые технологии», «цифровая экономика», «цифровизация», «электронная информационнообразовательная среда вуза». Ведутся масштабные работы по внедрению цифровых технологий во все сферы деятельности. Учреждения культуры и социальной сферы по-прежнему нуждаются в новых кадрах, способных разрабатывать, внедрять и поддерживать web-сайты, web-сервисы, электронный документооборот, разрабатывать маркетинговые и рекламные информационные продукты.

\section{Примечания}

1. Арбатская О. А., Баторов А. Р., Бурлова Е. Н. Современные направления подготовки кадров для социально-культурной сферы в области внедрения новых информационных технологий // Новые информационные технологии в культуре и образовании : материалы регион. науч.-практ. конф. Улан-Удэ : Изд.-полигр. комплекс ВСГАКИ, 2000. С. 98-102.

2. Вестник Восточно-Сибирского государственного института культуры. 2013. № 2.124 c.

3. Инфокоммуникационные и вычислительные технологии и системы : материалы семинара молодых ученых в рамках 3 междунар. конф., г. УланУдэ - оз. Байкал, 6-11 сент. 2010 г. Улан-Удэ : Изд.-полигр. комплекс ВСГАКИ, 2010. 229 с.

4. Инфокоммуникационные и вычислительные технологии и системы : материалы Всерос. конф., г. Улан-Удэ - оз. Байкал, 5-6 авг. 2003 г. УланУдэ : Изд-во Бурят. гос. ун-та, 2003. 152 с.

5. Информационные технологии и вычислительные системы : материалы семинара молодых ученых с междунар. участием, г. Улан-Удэ - оз. Байкал, 22-26 июня 2011 г. Улан-Удэ : Изд.-полигр. комплекс ВСГАКИ, 2011. $245 \mathrm{c}$.

6. Михайлов А. И., Черный А. И., Гиляревский Р. С. Основы информатики. 2-е изд., перераб. и доп. М. : Наука, 1968. 756 с.

7. Новые информационные технологии в культуре и образовании : материалы регион. науч.-практ. конф. 26-30 июля 2000 года. Улан-Удэ : Изд.-полигр. комплекс ВСГАКИ, 2000. 167 с.

\section{References}

1. Arbatskaya O. A., Batorov A. R., Burlova Ye. N. Sovremennyje napravlenija podgotovki kadrov dlja social'no-kulturnoj sfery v oblasti vnedrenija novikh informacionnikh tehnologij [Modern specialties for socio-cultural sphere in the field of new information technology introduction] // Novije informacionnije tekhnologii $\mathrm{v}$ cul'ture i obrazovanii : materialy region. nauch.-prakt. konf. [New information technology in culture and education]. Ulan-Ude, 2000. Pp.98-102. [In Russ.].

2. Vestnik Vostochno-Sibirskogo gosudarstvennogo instituta cul'tury [Bulletin of East Siberian state institute of culture]. 2013. № 2. 124 p. [In Russ.]. 
3. Infokommunikacionnyje i vichislitel'nyje tekhnologii i sistemy : materialy seminara molodikh uchjenikh $\mathrm{v}$ ramkakh III mezdunar. konf., g. Ulan-Ude oz. Bajkal, 6-11 sent. 2010 g. [Infocommunicative and computational technology and systems : materials of the young scientists' seminar within the framework of the $3^{\text {rd }}$ intern.conf., Ulan-Ude-Lake Baikal, 6-11 Sept. 2010.]. Ulan-Ude, 2010. 229 p. [In Russ.].

4. Infokommunikacionnyie i vichislitel'nyie tekhnologii i sistemy : materialy Vseros. konf., g. Ulan-Ude - Bajkal, 5-6 avg. 2003 g. [Infocommunicative and computational technology and systems : materials of All-Russian conf., UlanUde city-Baikal, 5-6 August 2003]. Ulan-Ude, 2003. 152 p. [In Russ.].

5. Infokommunikacionnyje tekhnologii i vichislitel'nije sistemy : materialy seminara molodikh uchenikh s mezdunar. uchastijem. g. Ulan-Ude - oz. Bajkal, 22-26 ijunja. 2011 g. [Infocommunicative technology and computational systems : materials of the young scientists' seminar with intern. participation, Ulan-Ude city - Lake Baikal, 22-26 June 2011]. Ulan-Ude, 2011. 245 p. [In Russ.].

6. Michaylov A. I., Cherniy A. I., Gilyarevskiy R. S. Osnovy informatiki [Fundamentals of computer science]. $2^{\text {nd }}$ ed., rev. and enl.. M., 1968. 756 p. [In Russ.].

7. Novyje informacionnyje tekhnologii v cul'ture i obrazovanii : materialy reg. nauch.-prakt. konf. 26-30 ijulja 2000 goda [New information technology in culture and education : materials of the regional scient.-pract. conf. 26-30 July 2000]. Ulan-Ude, 2000. 167 p. [In Russ.]. 
Воронцова Л. С., Солнцева Г. Н.

Vorontsova L.S., Solntseva G.N.

\author{
КАФЕДРА ДИЗАЙНА - 15 ЛЕТ ТВОРЧЕСТВА \\ И ВОСПИТАНИЯ СОВРЕМЕННЫХ СПЕЦИАЛИСТОВ
}

\title{
THE DEPARTMENT OF DESIGN - 15 YEARS OF CREATIVITY AND EDUCATION OF MODERN SPECIALISTS
}

В статье рассматривается создание и современное развитие кафедры дизайна, основанной пятнадцать лет назад, которая стоит у истоков формирования школы дизайна во ВСГИК, и в целом, в Восточной Сибири и Дальневосточном федеральном округе.

The article considers the creation and modern development of the department of design set up fifteen years ago and that is at the source of forming the school of design in ESSIC, in Eastern Siberia and Far-Eastern federal region on the whole.

Ключевые слова: сценография, дизайн, кафедра дизайна, студенты, Восточно-Сибирский государственный институт культуры, творчество.

Keywords: scenography, design, department of design, students, East Siberian state Institute of culture, creativity.

Создание кафедры дизайна определили тенденции, связанные с возрастанием роли искусства дизайна, которое вошло в нашу жизнь, заменив одним словом то, что мы называли «художественное конструирование», «оформительское искусство», «сценография» и т.п.

В 1996 году, в академии по инициативе проректора по учебной работе Сергея Александровича Добрынина была создана «Лаборатория сценографии и дизайна». К работе были привлечены преподаватели сценограф Имеева Наталья Витальевна и художник-дизайнер Солнцева Галина Николаевна. Лаборатория занималась сценографией спектаклей и художественным оформлением различных мероприятий, таких как «Созвездие Лиры», «Студенческая весна», международный симпозиум «Байкальские встречи», музыкально-инструментальный конкурс «Кубок Байкала» и др.

В «Лаборатории сценографии и дизайна» проходила очень интересная совместная творческая работа педагогов и студентов кафедр, где преподавались дисциплины по сценографии и декоративно-художественное оформление.

Теоретические дискуссии, профессиональные, практические и методические споры преподавателей творческих направлений вуза привели к идее открытия специальности «Дизайн».

При поддержке и личном участии ректора Восточно-Сибирской государственной академии культуры и искусств, профессора Раисы Ивановны Пшеничниковой было создано отделение «Дизайн» при кафедре «Декора- 
тивно-прикладного искусства», заведующей которого стала Имеева Наталья Витальевна.

В 2005 году состоялся первый набор студентов на очное обучение на коммерческой основе по специальности 070601.65 «Дизайн», квалификация 070601.65 .04 «Дизайнер (дизайн среды), специализация: «Дизайн интерьера», «Ландшафтный дизайн». С 2006 года заведующей отделением становится Солнцева Галина Николаевна, которая создала высокопрофессиональный творческий коллектив, в который вошли:

Андрей Поликарпович Хомяков, известный скульптор, член Союза художников России, Заслуженный скульптор СССР, первым освоивший технологию изделий из керамики в республике;

Игорь Вацлавович Соколовский, член Союза архитекторов Российской Федерации, руководитель детской студии архитектуры и дизайна «Белый город»;

Любовь Сергеевна Воронцова, член Союза художников Российской Федерации, член Международной ассоциации «Союз дизайнеров», заслуженный художник Республики Бурятия;

Лариса Александровна Дагданова, член Международной ассоциации дизайнеров, ведущий модельер студии дизайна одежды «Лора-мода». Авторские коллекции одежды Ларисы Александровны демонстрировались в Республике Бурятия, по стране и за рубежом.

Валерий Константинович Гурьянов, кандидат исторических наук, доцент, член Союза защиты памятников архитектуры, им опубликованы работы об архитектурных памятниках Республики Бурятия;

Галина Николаевна Солнцева, руководитель студенческой учебнопроизводственной лаборатории, член Творческого Союза России, заслуженный работник культуры Республики Бурятия.

В декабре 2008 года отделение было выделено в самостоятельное структурное подразделение - кафедру дизайна. Образовательная программа направления подготовки «Дизайн» продолжает традиции Строгановского училища, и включила в себя дисциплины: академический рисунок, академическую живопись, академическую скульптуру и пластическое моделирование, конструирование, цветоведение и колористика, композиция, историю искусства и т. д. Эстетическое воспитание по этой программе становилось неким универсальным средством пробуждения творческой активности в каждом обучающемся без исключения.

Главной задачей кафедры является развитие всех видов дарования личности студента - интеллектуальных, технических, художественных. Отсюда важность и необходимость выполнения этой задачи для дальнейшей профессиональной практической деятельности выпускников. На кафедре ведется активная работа по внедрению инновационных форм и методов обучения в образовательный процесс: проводятся деловые игры, тренинги и т. П.

В 2020 году кафедра отмечает свое пятнадцатилетие, сегодня в состав кафедры входят 7 штатных педагогов: 3 доцента, 3 старших преподавателя, 1 преподаватель. Преподаватели и студенты кафедры живут напря- 
женной творческой жизнью, участвуя в самых разнообразных проектах вуза: Ольга Анатольевна Кабанова, доцент, заслуженный учитель Республики Бурятия, Татьяна Михайловна Решетникова, Анастасия Игоревна Красногорова, старший преподаватель, лауреат международных конкурсов, старший преподаватель, Игорь Анатольевич Тимаков, старший преподаватель, Андрей Анатольевич Клапотовский, преподаватель.

За время существования отделения, а затем кафедры дизайна преподавателями и студентами было реализовано около 150 творческих проектов. Кафедра активно взаимодействует с администрацией г. Улан-Удэ и районными администрациями Республики Бурятия, культурным центром г. УланУдэ, выполняют проекты федерального уровня; принимают участие в творческих мероприятиях (выставках, конкурсах и др.) вузовского, городского, регионального и международного уровней.

Педагоги кафедры, являясь практикующими специалистами, осуществляют персональные творческие проекты и руководство творческой работой студентов: разработка макетов, проектов в области дизайна среды (дизайн интерьера, проекты благоустройства и озеленения), произведений графического дизайна (эмблемы, гербы районов, брэнды и др.), созданием произведений изобразительного искусства (живопись, скульптура), фотоработы, коллекции костюмов.

Кафедра установила тесные связи и сотрудничает с ведущими дизайнерами и архитекторами, высококвалифицированными специалистами, а также с творческими союзами архитекторов, художников и дизайнеров города и России. Это такие известные ведущие специалисты и деятели в области архитектуры и дизайна: Мясищев М.Н., Дубов А.Ю., Элоян С.Н., Бухаев В.Б., Анчиров Д.Д.

Преподаватели кафедры ежегодно принимают в работе научных и научно-методических симпозиумах, конференциях, круглых столах и осуществляют руководство научно-исследовательской работой студентов, ими подготовлено полное учебно-методическое обеспечение образовательной программы в соответствии со стандартом.

Ежегодно студенты успешно и активно участвуют в олимпиадах, выставках, конкурсах, в работе различных секций в рамках научнопрактических конференциях, показывают не только высокий уровень научной подготовки, но и успешно раскрывают творческий потенциал, занимают призовые места, лауреатов и дипломантов международных, региональных конкурсов. Среди них дипломанты победители Международного конкурса «Кубок России»: Цыбиков Бадма, Бардаханова Галина, Семенникова Люба, Международного выставки-конкурса современного искусства «Art Week»: Жолдожбекова Динара, Матвеева Татьяна, Морозова Александра, Ануфриева Дарья. Наши выпускники Гадецкая Ксения и Бальжинимаева Мыдыгма в 2020 году стали победителями регионального конкурса за лучшую концепцию благоустройства территории площади Революции г. Улан-Удэ.

Кафедра стремится соответствовать духу времени, требованиям новых образовательных и профессиональных стандартов, воспитывая новое поколение специалистов в области дизайна. 


\section{Ериова О. С.}

Yershova O.S.

\section{ЦЕНТР ЗАОЧНОГО И ДОПОЛНИТЕЛЬНОГО ОБРАЗОВАНИЯ: ИСТОРИЯ СТАНОВЛЕНИЯ И РАЗВИТИЯ \\ CENTER OF EXTRAMURRAL AND ADDITIONAL EDUCATION: HISTORY OF FORMATION AND DEVELOPMENT}

В статье дается краткий экскурс в историю организации и развития центра заочного и дополнительного образования ВСГИК, рассмотрены структурные реорганизации. В статье изучены основные направления деятельности и основные достижения Центра.

The article provides a brief review of the history of organizing and developing the center of extramural and additional education and considers some structural reorganizations. The main activities and main achievements of the Center have been studied.

Ключевые слова: дополнительное профессиональное образование, система повышения квалификации. tem.

Keywords: additional professional education, professional upgrading sys-

Дополнительное профессиональное образование (ДПО) - важный элемент образовательной деятельности. В современных условиях дополнительное профессиональное образование становится особенно актуальным, т.к. ориентировано на потребности государства в высококвалифицированных кадрах.

Переживая на современном этапе активный процесс реформирования и поиска путей совершенствования подготовки кадров, система дополнительного профессионального образования требует ее осмысления с точки зрения организационного оформления, становления и развития. В связи с этим представляет интерес обращение к истории создания, опыту работы системы ДПО в Восточно-Сибирском государственном институте культуры, что и является целью данной статьи.

Решением Ученого совета академии в марте 1996 года был создан региональный институт дополнительного профессионального образования, директором которого была назначена доцент Галина Николаевна Родина. Задачей данного подразделения была разработка и реализация программ, относящихся к повышению квалификации, стажировкам, профессиональной переподготовке кадров отрасли, региона, и также проведение научных исследований в области дополнительного профессионального образования, формирования фонда учебных программ, обеспечение методическими и учебными пособиями [2, с. 99]. 
За короткое время существования РИДПО установил хорошие деловые связи с органами и учреждениями культуры и искусства, высшими и средними специальными заведениями Восточно-Сибирского региона [2, с. 81]. На договорной основе строили свою деятельность региональные факультеты - представительства академии (филиалы и представительства: Тувинский филиал, Читинский филиал, Якутское представительство и Иркутское представительство) [1, с. 43].

7 апреля 2000 г. на основании решения Ученого совета ВСГАКИ Региональный институт дополнительного профессионального образования переименовывается в Центр довузовской подготовки, который возглавила Кургузова Зоя Сергеевна, доцент кафедры маркетинга и менеджмента информационной деятельности. Основными функциональными задачами Центра стали: развитие познавательного интереса старшеклассников, поиск и поддержка талантливой молодежи, профориентационная работа с учащимися, пропаганда деятельности академии.

По решению Ученого Совета академии Центр довузовской подготовки объединился с региональным институтом дополнительного и профессионального образования в структурное подразделение Центр дополнительных образовательных услуг. Деятельность и структура Центра ДОУ определилась социальными заказами и условиями рынка образовательных услуг.

Система ДПО постоянно совершенствуется и в современных условиях возникает необходимость формирования гибкой системы дополнительного образования, с помощью которой человек может в течение всей жизни повышать свои профессиональные навыки, которые позволяют быть мобильной и творчески активной личностью. Институт культуры всегда шел в ногу со временем и был в гуще современных событий и с 2004 года, под руководством Перовой Елены Юрьевны, кандидата экономических наук, Центр в соответствии с запросами и потребностями граждан и различных учреждений организует на договорной основе обучение в различных формах, привлекая высококвалифицированных специалистов из числа профессорско-преподавательского состава академии [3, с. 40].

Положительные изменения, происходящие в Центре ДОУ, это результат работы всего коллектива. Инициативность, требовательность, устремленность к достижению целей, трудолюбие и коммуникабельность позволили структуре внести значительный вклад в подготовку и повышение квалификации кадров социально-культурной сферы.

За 10 лет активной работы в Центре прошли обучение 12822 человека, в том числе по программам высшего образования - 2487 чел., по программам профессиональной переподготовки - 91 чел., по программам повышения квалификации - 1141 слушатель, на различных краткосрочных курсах - 1239 чел., других образовательных услуг - 7864 чел., в том числе иностранные граждане.

На основании решения Ученого совета от 26.08.2015 г. произошло объединение структурных подразделений «Заочное отделение» и «Центр дополнительного и инновационного образования» с образованием структур- 
ного подразделения «Центр заочного и дополнительного образования» под руководством Ануевой Ирины Васильевны.

Сегодня в область деятельности Центра входит высшее образование по заочной форме, дополнительное профессиональное образование (повышение квалификации, профессиональная переподготовка), подготовительные курсы, профориентационная работа.

Профессиональная переподготовка специалистов является важным направлением работы Центра, цель которой - получение ими знаний, умений и навыков по дополнительным образовательным программам, предусматривающим изучение отдельных дисциплина, необходимых для выполнения нового вида профессиональной деятельности [3, с. 40]. Наиболее популярные такие программы как «Менеджмент организаций культуры и искусства», «Библиотечно-информационная деятельность», «Психологопедагогическое образование», учитывая практическую направленность и актуальность, в перечень программ переподготовки вошли «Режиссура концертно-зрелищных форм», «Музейное дело», «Режиссура драмы». Количество слушателей программы переподготовки в период с 2015 года по 2020 год составило более 350 слушателей.

Другое направление работы Центра - разработка и реализация программ повышения квалификации, которые способствуют обновлению теоретических и практических знаний специалистов в связи с повышением требований к уровню квалификации и необходимостью освоения современных методов решения профессиональных задач [4, с. 236].

За последние пять лет курсы повышения квалификации прошли свыше 3000 слушателей по темам: «Психолого-педагогические аспекты профессиональной подготовки как вида образовательной деятельности», «Арт-терапия в образовании», «Основы экскурсоведения для начинающих. Базовый курс», «Актуальные вопросы управления персоналом современной организации», «Пространственная модернизация современной библиотеки», «Школа руководителя: стратегия развития КДУ Иркутской области», «Методы танцевально-двигательной терапии в образовании», «Улан-Удэ в экскурсионных объектах («Зеленая линия»)», «Основы менеджмента и маркетинга сельских культурно-досуговых учреждений», «Современные тенденции в организации музейной работы», «Государственный и муниципальный архивы: организация и методика работы», «Современная библиотека в социокультурном пространстве» и др.

В вузе уделяется особое внимание повышению квалификации профессорско-преподавательского состава, в реализации этого направления играет значительную роль ЦЗиДО. Ежегодно центр организует различные курсы по дополнительному образованию без ограничения минимального уровня образования и сроков подготовки, такие как: мастерство устной речи, риторика, организатор детского досуга (вожатый), гид-проводник, китайский язык, деловой английский язык. Количество слушателей курсов дополнительного образования с 2015 г. по 2020 г. составило 3000 человек.

В настоящее время современные тенденции развития ДПО актуализируют внимание к дистанционным образовательным технологиям. В этой 
связи Центр принимает активное участие в специальной программе профессионального обучения и дополнительного профессионального образования лиц в возрасте 50-ти лет и старше, а также лиц предпенсионного возраста, организовывая дистанционное обучение слушателей по программам «Менеджмент организаций культуры и искусства», «Библиотечноинформационная деятельность».

Одним из важных направлений работы ЦЗиДО является организация учебного процесса по заочной форме в ускоренные сроки. Данная форма обучения позволяет приобрести новые профессиональные знания и навыки. В период с 2015 г. по 2020 г. количество студентов, получивших высшее образование по заочной форме обучения в ускоренные сроки, составило 614 человек.

Сплочённая и слаженная работа профессорско-преподавательского состава вуза и Центра заочного и дополнительного образования на протяжении длительного периода обеспечивает сферу культуры и искусства высококвалифицированными специалистами, которые являются основой интеллектуального потенциала региона.

\section{Примечания}

1. Доржиев Б. Ш. Восточно-Сибирский государственный институт культуры в 1968-1990 гг. (становление-развитие). Улан-Удэ, 2016. 43 с.

2. Никифоров С. И. Виват, академия! Улан-Удэ, 2000. 99 с.

3. Перова Е. Ю. Роль центра дополнительных образовательных услуг ВСГАКИ в развитии дополнительного профессионального образования // ФГОУ ВПО «Восточно-Сибирская государственная академия культуры и искусств» в культурном пространстве Восточной Сибири и Севера : материалы межрегион. круглого стола. Улан-Удэ, 2007. С. 38-41.

4. Перова Е. Ю. Состояние и перспективы развития дополнительного профессионального образования во ВСГАКИ // Кадровое обеспечение социально-культурной сферы Восточной Сибири: состояние и перспективы развития : материалы межрегион. науч.-практ. конф. 20-21 нояб. 2003 г. УланУдэ, 2003. С. 235-239.

\section{References}

1. Dorzhiev B. Sh. Vostochno-Sibirskij gosudarstvennyj institut kul'tury v 1968-1990 gg. (stanovlenije-razvitije) [East Siberian state institute of culture in 1968-1990 (formation and development). Ulan-Ude, 2016, 43 p. [In Russ.].

2. Nikiforov S. I. Vivat, akademija! [Vivat, academy!]. Ulan-Ude, 2000. 99 p. [In Russ.].

3. Perova Ye. Yu. Rol' centra dopolnitel'nykx obrazovatel'nykx uslug VSGAKI v razvitii dopolnitel'nogo professional'nogo obrazovanija [The role of center of additional educational services of ESACA in the development of additional professional education // FGOU VPO «Vostochno-Sibirskaja gosudarstvennaja akademija kul'tury i iskusstv» v kul'turnom prostranstve Vostochnoj Sibiri i severa: materialy mezhreg. kruglogo stola [FSEI HPE «East Siberian state academy of culture and arts» in the cultural space of Eastern Siberia and the north : materials of the interreg. round table]. Ulan-Ude, 2007. Pp. 38-41. [In Russ.]. 
4. Perova Ye. Yu. Sostojanije i perspektivy razvitija dopolnitel'nogo professional'nogo obrazovanija vo VSGAKI [Condition and perspectives of developing additional professional education in ESSAC] // Kadrovoje obespechenije social'no-kul'turnoj sfery Vostochnoj Sibiri: sostojanie i perspektivy razvitija : materialy mezhregional'noj nauchno-prakticheskoj konferencii 20-21 nojabrja 2003 g. [Staffing of the socio-cultural sphere of Eastern Siberia: condition and perspectives of development : materials of the interreg. scient.-pract. conf. 20-21 November, 2003]. Ulan-Ude, 2003. Pp.235-239. [In Russ.]. 


\title{
РОЛЬ ОЛИМПИАДНОГО ДВИЖЕНИЯ В РАЗВИТИИ КОММУНИКАТИВНОЙ КОМПЕТЕНЦИИ СТУДЕНТОВ ВСГИК
}

\author{
THE OLYMPIAD MOVEMENT ROLE IN DEVELOPING \\ COMMUNICATIVE COMPETENCE OF THE STUDENTS OF ESSIC
}

В статье раскрывается роль олимпиадного движения в ВосточноСибирском государственном институте культуры, определяется его значимость в развитии коммуникативной компетенции студентов. Прослеживается динамика изменения конкурсных заданий в коммуникативном аспекте. Подчёркивается высокая результативность итогов участия студентов вуза в олимпиадах и отмечается вклад педагогов кафедр иностранных языков и общей лингвистики, литературы и языкознания.

The article reveals the role of the olympiad movement in East-Siberian state institute of culture and determines its significance in developing students' communicative competence. The dynamics of changing the contest tasks in the communicative aspect is traced. High results of the students' participation of the higher educational institution in the olympiads are stressed and the contribution of the teachers of the departments of foreign languages and general linguistics and literature and linguistics is noted.

Ключевые слова: студенческая олимпиада, олимпиадное движение, коммуникативная компетенция, английский язык, бурятский язык, русский язык и культура речи, монгольский язык, задание, тематика.

Keywords: students' olympiad, olympiad movement, communicative competence, the English language, the Buryat language, the Russian language, the Mongolian language, task, themes.

Высшие учебные заведения России в современных условиях сталкиваются с многочисленными вызовами, которые требуют тщательного анализа и проработки. Модернизации требуют как сама система организации обучения, нацеленная на соответствие федеральным государственным стандартам высшего образования (ФГОС ВО), так и подходы к формированию универсальных и профессиональных компетенций будущих специалистов. Проведение лекций, семинаров и практических занятий с использованием инновационных образовательных технологий сегодня становится велением времени. Кроме того, возрастает роль внеаудиторных видов деятельности студентов, нацеленных на развитие их интеллектуального и творческого потенциала. В частности, активное участие студентов в олимпиадах по лингвистическим дисциплинам и в олимпиадах филологической направленности способствует формированию у обучающихся умений и навыков грамотно подходить к решению нестандартных задач, логически обосновывать вы- 
двигаемые тезисы, аргументировано доказывать свою точку зрения по заданной проблеме или проблемной ситуации. Все эти составляющие коммуникативной компетенции необходимы в профессиональной деятельности, что, вне всяких сомнений, повышает конкурентоспособность будущих специалистов сферы культуры и искусства. Именно олимпиадное движение способствует значительному прогрессу в знаниях обучаемых, повышению их самооценки и мотивации к дальнейшему изучению языков.

Кафедры иностранных языков и общей лингвистики, литературы и языкознания Восточно-Сибирского государственного института культуры (ВСГИК) накопили огромный опыт не только подготовки команд к участию в республиканских, региональных, международных студенческих олимпиадах среди высших учебных заведений, но и организации и проведения таких конкурсов. На протяжении более 25 лет педагоги кафедр прилагают немало усилий по развитию олимпиадного движения в вузе культуры по таким дисциплинам, как «Английский язык», «Бурятский язык», «Русский язык и культура речи», «Монгольский язык» и др., вовлекая студентов в процесс языковой подготовки. Объединение усилий как педагогов, так и самих обучаемых - необходимое условие достижения результативности, а взаимодействие с профессиональным сообществом и привлечение компетентного жюри из числа носителей языка, специалистов образовательных и научных учреждений только способствуют коллаборации вузов-участников.

Цель статьи - провести анализ участия студентов ВСГИК в олимпиадах республиканского и международного уровня по лингвистическим дисциплинам и учебным предметам филологической направленности, выявить особенности, специфику их проведения, а также определить вклад педагогов кафедр в развитие олимпиадного движения.

Основным документом, регламентирующим проведение подобных олимпиад, является Положение. Оно ежегодно разрабатывается вузоморганизатором и принимается вузами-участниками, определяя статус, цели, задачи и порядок их проведения. Так, например, целью и задачами олимпиад последних лет являются: повышение качества подготовки будущих специалистов в области коммуникации на русском, бурятском и иностранных языках с целью развития их коммуникативной компетенции; содействие созданию профессионального сообщества и обмену опытом в сфере преподавания лингвистических дисциплин в высших учебных заведениях Республики Бурятия; развитие когнитивных умений будущих специалистов, их способности к самообразованию; популяризация и пропаганда изучения языков среди студентов высших учебных заведений; выявление одаренной молодежи и активизация ее научного и творческого потенциала.

Результативность участия в подобных конкурсах достигается благодаря наработанной методике подготовки, нацеленной на развитие способности самостоятельно и творчески решать различные коммуникативные задачи в рамках тематики, ежегодно определяемой путем согласования со всеми вузами. Особенностью олимпиад последних лет является их тематическая насыщенность, отражающаяся в актуальных, представляющих интерес темах. Так, если взглянуть на тематику в ретроспекции, то можно заметить, 
что вузы следуют методике проблемно-ориентированного обучения, когда центральной становится проблемная ситуация, которую надо разрешить в течение ограниченного количества времени. Тематика олимпиад необычайно расширена, так как акцентируется роль молодежи в решении актуальных проблем современности: «Молодежь в гармонии с окружающей средой и миром», «Молодежные инициативы», «Арктический диалог в глобальном мире», «Бросай Интернет - вставай на лыжи», «Перспективы и проблемы молодежи в глобальном мире», «Современная молодежь и перспективы развития туризма в Республике Бурятия», «Живи в гармонии с окружающим миром», «Мир, молодежь, досуг», «Слова, что созидают мир», «Язык - орудие мышления» и др.

Конечной целью обучения языкам является формирование коммуникативной компетенции как способности осуществлять речевую деятельность в устной и письменной формах языковыми средствами в соответствии с целью и нормами речевого поведения в различных ситуациях общения. Поскольку коммуникативная компетенция формируется из трех видов компетенций (языковой, речевой, социокультурной), можно утверждать, что конкурсные задания позволяют активизировать и расширять умения и навыки по изучаемым языкам. Знание системы языка, правил функционирования языковых единиц в речи отображается в способности пользоваться языком для формулирования мыслей (собственно языковая компетенция). Лексикограмматические тесты, тесты на понимание содержания прочитанного, диктанты и переводы текстов на олимпиадах демонстрируют сформированность языковой компетенции. Речевая компетенция предполагает умение пользоваться языком для выражения своих мыслей и интенций в различных формах, реализуясь в дебатах, спонтанных диалогах, кейс анализе ситуаций, конкурсах ораторов, инсценировках, стихотворных экспромтах, в полной мере. Знание национально-культурных особенностей, специфики речевого поведения носителей языка и умение понимать и адекватно использовать эти знания в процессе общения - показатель социокультурной компетенции участников олимпиад, которые проявляются в подготовке и демонстрации традиционных обрядов и обычаев, мультимедийных презентациях об уникальности природного и культурного наследия народов.

Макси-задача по формированию коммуникативной компетенции и определяет содержательное наполнение конкурсных заданий всех лингвистических олимпиад в соответствии с меняющимися ФГОС ВО. Поскольку олимпиада представляет определенное системное явление, проанализировав условия и требования к заданиям, можно проследить, как менялись с течением времени содержательное наполнение заданий и их уровень. В начале 2000-х годов на олимпиадах типичными были задания на выполнение лексико-грамматических тестов, тестов на понимание содержания прочитанных научно-популярных текстов, а также показ инсценировок с элементами театрализации по тематике с использованием музыкального сопровождения. Компетентное жюри обращало внимание на соответствие содержания высказывания заданной теме, правильность и идиоматичность речи, объем и структурированность высказываний, речевую плотность и плотность ино- 
язычной коммуникации, артистизм и музыкально-художественное оформление выступления. В 2006-2007 гг. организаторы ввели в структуру проведения олимпиад конкурсы на продуктивный вид речевой деятельности - диалогическое высказывание по заданной ситуации общения на основе жеребьёвки и компьютерное тестирование на автоматический контроль усвоения знаний, что потребовало более качественной и продолжительной подготовки олимпийцев. С 2012 года стали внедряться новые творческие комбинированные задания на развитие навыков неподготовленной диалогической речи и полилога. Например, на основе просмотра фрагмента видеофильма необходимо было продумать его завершение и разыграть остальную часть так, как бы могли разворачиваться последующие события, по сути, представить компетентному жюри инсценировку продолжения видеофильма. Еще одним интересным новшеством в командном первенстве в эти годы стали задания на решение реальной проблемы (case study). Командам предлагались конкретные ситуации делового общения, специально выделяемые на основе фактического материала, с целью последующего разбора и принятия решения. В ходе работы над кейсом студентам нужно было выполнить задания на систематизацию и анализ текстовых материалов, сделать интернет-запрос для уточнения деталей конкретной информации. Задача студентов состояла в творческой разработке стратегий решения проблем деловой ситуации с демонстрацией культурной и языковой специфики делового общения, а также навыков публичной речи. Другая форма публичной защиты кейса это выступление спикера команды, который должен убедить членов жюри принять резолюцию. Спикер команды должен продемонстрировать высокий уровень ораторского мастерства, умение аргументировать и обосновывать решение, выступая со своим кейсом в поддержку данной резолюции. Задача команды оппонента - постараться «разрушить» аргументы спикера с помощью контраргументов.

В последние годы командное первенство проходит в формате дебатов, когда члены команды представляют парламентское обсуждение определенного тематического вопроса. Каждый участник команды «играет» свою роль: он может быть модератором, премьер-министром, лидером оппозиции, членом правительства или членом оппозиции. Если обратить внимание на оценивание дебатов, то определяющими параметрами являются содержание и тематическая целостность (соответствие аспектов и аргументов (контраргументов) теме дебатов, полнота, глубина, доказательность и разнообразие аргументов (контраргументов), оригинальность подхода к раскрытию темы; коммуникативное поведение, логика и последовательность изложения, беглость говорения всех участников команды, адекватность и естественность речи (в том числе соответствие стилю общения), интерактивные стратегии; языковое оформление (лексическое, грамматическое, фонетическое оформление речи). С 2017 года студенты ВСГИК успешно участвуют в Открытых международных Интернет-олимпиадах на базе Новосибирского государственного технического университета, демонстрируя высокий уровень владения языковыми нормами. 
Анализируя изменение конкурсных заданий во времени, можно констатировать сдвиг в сторону коммуникативности, когда определяющим фактором при оценивании участников становится именно сформированность коммуникативных навыков и умений. Это, несомненно, отличительное преимущество и огромный шаг вперед. Кроме того, участвуя в олимпиадах подобного уровня, студенты вуза значительно продвигаются в своем развитии, раскрывают свой потенциал, видят свои слабые стороны, возможности и сильные стороны «соперников». В ходе подготовки становится важным научить аргументированно вести диалог или полилог: выдвигать аргументы за и против, обосновывать свою точку зрения, опровергать мнение оппонента, чтобы, в конечном итоге, прийти к консенсусу.

Необходимо отметить, что студенты ВСГИК успешно принимают участие не только в подобных лингвистических конкурсах, но и в олимпиадах общей филологической направленности. К их числу следует отнести Межвузовскую студенческую олимпиаду «Дүрбэн бэрхэ», Международную студенческую олимпиаду «Миф-фольклор-литература монголоязычных народов в контексте истории и современности». Цель олимпиад - создание дополнительных условий в рамках сохранения и развития монгольских языков (бурятского, калмыцкого, монгольского), фольклора, литературы, культуры монголоязычных народов в субъектах РФ, а также за рубежом, повышения мотивации и усиления интереса к изучению и совершенствованию знания родного языка, воспитания уважительного и бережного отношения к родной культуре и истории, развития эрудиции, литературоведческих и культурологических способностей студентов. К числу олимпиадных заданий относятся: подготовка и защита проекта-презентации «Фольклорнообрядовая импровизация»; интеллектуальный турнир по этнической генеалогии; генеалогические задачи «Алгебра родства» (на материале бурятского языка); комплексный лингвостилистический анализа текста; написание эссе, творческое задание (подготовка и защита буктрейлера по фольклору и литературе монголоязычных народов) на бурятском языке и др.

Безусловно, подготовка к олимпиадам и само участие в них закрепляют знания особенностей систем языков разных народов, развивают умение логического мышления, раскрывают креативные возможности и творческое воображение обучаемых. Хороший уровень знания студентами английского, бурятского, русского и монгольского языков, вне сомнений, расширяют их возможности успешно решать поставленные задачи в рамках участия в олимпиадах. Призовые командные и личные места в республиканских, региональных и международных олимпиадах по указанным предметам свидетельствуют о профессионализме и новаторстве талантливых и опытных педагогов - руководителей команд и организаторов: заслуженного работника образования Республики Бурятия, к.пед.н., доцента Нимаевой И.Б., к.филол.н., доцентов Забановой Л.Е., Хобраковой Л.М., Шойбоновой С.В. и Ринчиновой А.В. Именно благодаря эффективной, напряженной работе этих преподавателей, олимпиадное движение в регионе развивается в поступательном направлении. 
Таким образом, активное участие студентов ВСГИК способствует закреплению теоретических знаний по изучаемым дисциплинам, повышению их интеллектуальной активности, формированию научного и творческого потенциала личности обучаемых. Несомненно, роль олимпиадного движения в современных условиях неуклонно возрастает, способствуя формированию коммуникативной компетенции у будущих специалистов сферы культуры и искусства. 


\section{Рещиков Н. И.}

Reshchikov N. I.

\section{ИЗ ИСТОРИИ НАРОДНО-ПЕВЧЕСКОГО ОБРАЗОВАНИЯ В ВОСТОЧНО-СИБИРСКОМ ГОСУДАРСТВЕННОМ ИНСТИТУТЕ КУЛЬТУРЫ}

\section{FROM THE HISTORY OF FOLK SINGING EDUCATION AT EAST SIBERIAN STATE INSTITUTE OF CULTURE}

Одной из ярких страниц в истории ВСГИК является открытие в 1983 году отделения по подготовке руководителей самодеятельных народнохоровых коллективов. Это событие не только положило начало формированию многоуровневой системы народно-певческого образования в регионе, но и в немалой степени способствовало целенаправленной и систематической работе по собиранию, изучению и популяризации песенного фольклора народов Восточной Сибири.

В преддверии 60-летнего юбилея ВСГИК, автор статьи - один из первых студентов этого отделения - характеризует деятельность созданной впоследствии кафедры народного пения, информирует о ее достижениях и выпускниках. Особенно подчеркивается роль вуза в развитии народнопевческого образования, исполнительства и народного художественного творчества Восточной Сибири и Забайкалья.

One of the brightest pages in the history of East Siberian state Institute of culture is opening the department for training leaders of amateur folk choirs in 1983. This event not only laid the foundation for the formation of the multilevel system of folk singing in the region, but also contributed, to some extent, to the focused and systematic work of collecting, studying and popularizing song folklore of the peoples of Eastern Siberia.

On the eve of the $60^{\text {th }}$ anniversary of East Siberian state Institute of culture, the author of the article as one of the first students of this department characterizes the activity of the department of folk singing created subsequently, informs about its achievements and graduates. The role of East Siberian State Institute of Culture in the development of folk singing, performance and folk art of Eastern Siberia and Transbaikalia is given emphasis to.

Ключевые слова: история, народно-певческое образование, подготовка специалистов, народное пение, народный хор.

Keywords: history, folk singing education, specialists' training, folk singing, folk choir.

В 60-е гг. прошлого века одним из самостоятельных направлений музыкального исполнительского искусства становится русское народнопевческое исполнительство и, по словам профессора М.В. Медведевой, начинает активно развиваться в профессиональной, самодеятельной и 
учебной формах [1, с. 19]. Закономерным явлением стало открытие в стенах ГМПИ им. Гнесиных отделения по подготовке руководителей народных хоров, положившее начало истории народно-певческого образования в России. Это знаковое событие, имеющее большое значение для национальной музыкальной культуры, произошло в 1966 г. Спустя год подобное отделение открылось в Саратовской государственной консерватории им. Л. В. Собинова, инициируемое художественным руководителем Уральского государственного русского народного хора Л.Л. Христиансеном. «Открытие подготовки руководителей народного хора, а затем специалистов сольного народного пения в вузах и средних специальных учебных заведениях России явилось в те годы важной вехой, обозначившей на государственном уровне осознание необходимости сохранения и развития национально-певческих традиций и определившей важнейшую составляющую в решении этой многотрудной задачи подготовку профессиональных кадров» [2, с. 5-6].

Начавшийся процесс становления и развития народно-певческого образования в России постепенно расширял свои горизонты. Поэтому закономерным явлением стало открытие в 1983 г. при кафедре хорового дирижирования ВСГИК отделения по подготовке руководителей самодеятельных народно-хоровых коллективов. Данное событие стало важным для Восточно-Сибирского региона. Оно не только положило начало формированию многоуровневой системы народно-певческого образования в регионе, но и в немалой степени способствовало целенаправленной и систематической работе по собиранию, изучению и популяризации песенного фольклора народов Восточной Сибири.

Первый набор студентов осуществила выпускница Саратовской государственной консерватории Людмила Петровна Лисогорова. Ученица выдающегося музыковеда, педагога, ученого, Л.Л. Христиансена, Л.П. Лисогорова сумела заложить основы региональной подготовки профессиональных кадров в области народно-певческого искусства, безусловно имеющей свою специфику. Фундаментальные знания, полученные в консерватории, сложились впоследствии в стройную рациональную систему и явились той базой, на основе которой постепенно сформировались методические и педагогические принципы обучения студентов в полиэтническом регионе.

В связи с отсутствием в республике специалистов, необходимых в работе с самодеятельными народными хорами, с самого начала было принято решение об использовании одновременно двух форм обучения очной и заочной. Таким образом, первый набор студентов на отделение по подготовке руководителей самодеятельных народно-хоровых коллективов был произведен в 1983 г. В целях более качественного освоения одной из важнейших профилирующих дисциплин - «Методика собирания и расшифровки народных песен» был создан специализированный кабинет, оснащенный всем необходимым оборудованием для проведения учебных занятий. Уже в конце первого учебного года, в июне 1984 г., студенты под руководством Л.П. Лисогоровой выехали в свою первую фольклорную 
экспедицию. Сбор песенного фольклора производился в трех семейских селах - Большой Куналей, Десятниково и Тарбагатай.

Сосредоточив в своих руках преподавание основных специальных дисциплин, Л.П. Лисогорова уже в скором времени пришла к осмыслению необходимости пополнения отделения преподавателями, имеющими профилирующее образование. Так, в 1985 г. была приглашена для работы в отделении выпускница Ленинградского государственного института культуры им. Н.К. Крупской Виктория Сергеевна Рещикова (Оганесян).

Будучи приверженцем ленинградской школы этномузыкологии и воспитанной на трудах выдающихся ее представителей Е.В. Гиппиуса, И.И. Земцовского, А.М. Мехнецова, Т.А. Берштам и других ученых, В.С. Рещикова придерживалась принципиальной позиции в отношении подходов к обучению народному пению. Вместо концертно-сценического стиля исполнения народных песен, настойчиво насаждаемого в то время многими деятелями музыкального искусства, она ориентировала студентов на постижение этноинтонационной природы народной песни, развитие эмоционально-ценностного отношения к песенному фольклору в целом.

Серьезным фактором, детерминирующим поиск методических приемов обучения народному пению, явился полиэтнический состав студенческих групп, состоящих из русских, бурят, якутов, тувинцев. При универсальности форм и методов обучения вокалу необходимо было учитывать особенности этнического пения. Одним из путей решения задачи стало освоение студентами в рамках вокальных дисциплин фольклорных произведений народов Восточной Сибири, что, с одной стороны, способствовало реализации принципа межкультурной коммуникации, а с другой - формированию у студентов навыков кросс-культурной грамотности.

Одновременно с учебной и учебно-методической работой В.С. Рещикова начала активно заниматься собиранием и расшифровкой песенного фольклора казаков и семейских (старообрядцев) Забайкалья. Собранный ею подлинный народно-песенный материал включался в репертуар учебных хоров, а также в репертуар вокальной группы, созданной ею из числа студентов отделения при ансамбле народной музыки «Сибирский сувенир» (художественным руководителем ансамбля являлся доцент В.В. Китов). Часть записанных и расшифрованных В.С. Рещиковой произведений песенного фольклора семейских впоследствии вошла в нотное издание «Цветок в янтаре», подготовленное ею совместно с Н.И. Рещиковым [3].

В 1986 г. в работу отделения влилась сначала концертмейстером, а спустя год - преподавателем, выпускница ВСГИК Галина Александровна Даренских, уже имевшая на тот период опыт работы с самодеятельным народным хором. Проработав во ВСГИК всего несколько лет (до 1989 г.), Г.А. Даренских, между тем, внесла в учебную, учебно-методическую, научную и творческо-исполнительскую жизнь молодого отделения существенный вклад. Ее знания, профессиональный опыт, творческое вдохновение подняли на новый уровень хоровой класс. Обладая ярким 
педагогическим даром, она последовательно воспитывала в студентах любовь к народно-хоровому искусству. Артистизм и профессиональное владение вокально-исполнительским мастерством позволили ей успешно влиться в состав Ансамбля народной музыки «Сибирский сувенир» и стать его солисткой.

В 1989 г. Г.А. Даренских была направлена в ассистентуру-стажировку в ГМПИ им. Гнесиных по классу сольного народного пения. Ее руководитель - Народная артистка СССР, профессор Н.К. Мешко вскоре рекомендовала Галину Александровну на должность главного хормейстера Государственного академического Северного русского народного хора. С 1990 г. она становится главным хормейстером этого прославленного коллектива. В 2001 г. за личные заслуги в плодотворной творческой деятельности, подготовке концертных программ, принесших широкое общественное признание, Г.А. Даренских было присвоено почетное звание «Заслуженный артист Российской Федерации».

Образование в 1989 г. самостоятельной кафедры народного пения расширило горизонты учебной, научной, методической и творческоисполнительской деятельности. В состав новой кафедры вошли доцент Я.А. Бодягин, преподаватели Г.А. Даренских, В.С. Рещикова, А.М. Лесовиченко и окончившие годом ранее МГИК О.Н. Судакова и В.Х. Хадонова (ныне Назарова). Заведующим кафедрой был назначен Я.А. Бодягин - опытный преподаватель, выпускник Уральской государственной консерватории, имеющий на то время почетное звание «Заслуженный работник культуры Бурятской АССР».

Яков Азарович Бодягин - человек необыкновенно доброй души, много сил и энергии отдал становлению созданного структурного подразделения. На кафедре он преподавал дирижирование, хороведение, методику работы с народным хором, руководил практикой студентов, являлся хормейстером вокальной группы ансамбля народной музыки «Сибирский сувенир». В то время этот ансамбль особенно интенсивно вел гастрольную деятельность, участвовал в многочисленных международных фольклорных фестивалях, проходящих в Италии, Франции, Испании, Канаде и других странах. И везде, где бы ни побывал ансамбль, его вокальная группа под руководством Я.А. Бодягина достойно представляла фольклорное искусство народов Восточной Сибири. В 2000 г. трагический случай оборвал жизнь этого талантливого педагога и замечательного человека...

Возвращаясь ко времени становления кафедры народного пения, необходимо охарактеризовать его, как период ее расцвета. Вновь созданная кафедра все увереннее заявляла о себе. Неуклонный рост количества студентов способствовал расширению преподавательского состава кафедры. В 1990-е гг. пришли на кафедру С.Ц.-Н. Очиров, Т.С. Танганова, Е.С. Штейн, М.С. Антонова, Г.М. Евтушенко (Терентьева). Каждый из педагогов внес свой особенный вклад в развитие кафедры и подготовку специалистов, для каждого был характерен творческий подход к учебному процессу. 
Смелым новаторством стал опыт занятий с хором и ансамблем Галины Михайловны Евтушенко (Заслуженного работника культуры РФ, доцента). Являясь главным хормейстером фольклорного ансамбля «Забава», в то время уже перешагнувшего порог ВСГИК и ставшего профессиональным, она успешно совмещала художественно-творческую деятельность с педагогической. Выступая композитором и аранжировщиком многих вокальных произведений, Галина Михайловна со свойственной ей любовью к джазовой гармонии, привнесла некоторые ее свойства и черты в собственные обработки народных песен. Впоследствии одни из них вошли в сборник авторских произведений под названием «Отчий край» [4], другие - пополнили репертуар профессиональных и самодеятельных народно-певческих коллективов.

Придя на кафедру, Г.М. Евтушенко привнесла с собой т.н. наддиалектный стиль исполнения народных песен, крепко утвердившийся в то время в народно-хоровом искусстве, особенно профессиональном. Установка на реализацию в обучении принципа связи теории и практики - двух неразрывно связанных сторон единого процесса познания, многолетний практический опыт работы с народно-певческими коллективами и богатый творческий потенциал позволили Г.М. Евтушенко добиться значительных результатов в педагогической сфере. Многие ее ученики сегодня успешно трудятся в сфере культуры, искусства и образования. Среди них О.Н. Петунина, Г.В. Плотникова, Ю.Е. Варданян (Суслова), Р.В. Лопатин и др.

Важно отметить, что открытие кафедры способствовало активизации научных исследований в области культуры и искусства. Наиболее плодотворным стал период 2000-2006 гг. Именно в это время окончили аспирантуру и успешно защитили кандидатские диссертации О.Н. Судакова («Русские лирические протяжные песни Забайкалья: региональная традиция: Вторая половина ХХ века», 2000 г.), М.С. Антонова («Художественное самодеятельное творчество в культуре Бурятии», 2000 г.), Т.Г. Балханова («Композиторская школа в музыкальной культуре Бурятии как фактор межкультурной интеграции народов России», 2002 г.), В.Х. Назарова («Певческое искусство старообрядцев Забайкалья - семейских: Опыт историко-музыковедческого исследования», 2003 г.), Т.С. Танганова («Певческие традиции западных бурят: эхиритов и булагатов: Опыт историко-искусствоведческого исследования», 2006 г.).

Особенно весомый вклад в развитие регионального народнопевческого образования и исполнительства, в разработку теоретической базы в области локальных песенных традиций Предбайкалья и Забайкалья внесли О.Н. Судакова, В.Х. Назарова и Т.С. Танганова. В течение 20-ти лет ими велась кропотливая работа по вокальному воспитанию студентов и в хоровом коллективе, и в классе по постановке голоса, в результате чего многие из учеников становились лауреатами и дипломантами различных фестивалей и конкурсов.

Надо отдать должное Оксане Николаевне Судаковой (Заслуженному работнику культуры РБ, доценту), усилиями которой народно-певческое образование в Институте заметно оживилось с назначением ее в 2000 г. на 
должность заведующего кафедрой. О.Н. Судакова на тот момент завершила обучение в аспирантуре, защитила диссертацию и получила ученую степень кандидата филологических наук. Будучи сторонником исполнения студентами местного песенного фольклора, О.Н. Судакова организовывала и проводила большую собирательскую работу, выезжая со студентами в фольклорные экспедиции. Собранный материал неизменно пополнял репертуар учебных народно-певческих коллективов.

Наравне с организационной, педагогической и научноисследовательской работой, О.Н. Судакова успешно осуществляла творческо-исполнительскую деятельность. Она стояла у истоков создания профессионального фольклорного ансамбля «Забава». Созданный первоначально на базе ВСГИК (1989 г.), в состав которого вошли студенты разных специализаций, в том числе и студенты-народники, ансамбль «Забава» под руководством Н.Б. Осипова (ныне Заслуженного деятеля искусств РБ и РФ) уже в следующем году стал дипломантом первого Всероссийского телерадиоконкурса исполнителей народной песни «Голоса России», состоявшегося в г. Смоленск. Спустя год ансамбль был приглашен для выступления на сцене Колонного зала Дома Союзов и концертном зале им. П.И. Чайковского. Все это время хормейстерскую работу осуществляла О.Н. Судакова. Среди учеников Оксаны Николаевны - Н. Жарникова (Лабутина) и Л. Крылова (Шевелева), успешно защитившие под ее руководством кандидатские диссертации, О. Эпова, Е. Рейзвих и И. Хавлина - лауреаты международных конкурсов и фестивалей.

Значительными научными и творческими достижениями отмечается педагогическая деятельность Венеры Хушиновны Назаровой (Заслуженного работника культуры РБ, канд. искусствоведения, доцента). Работая на кафедре, Венера Хушиновна параллельно осуществляла хормейстерскую работу в ансамбле «Сибирский сувенир» (1989-1994 гг.), а после и в муниципальном фольклорном ансамбле «Забава» (1999-2000 гг.), трудилась регентом церковного хора храма «Вознесение Господне» (с 2001 г.).

За время работы в ВСГИК В.Х. Назарова воспитала немало талантливых специалистов. В числе ее учеников - Заслуженная артистка РБ Т. Пантелеева, Заслуженная артистка РБ Е. Шашина, Заслуженный работник культуры РБ С. Доржиев, Заслуженный работник культуры РБ В. Долженко и др.

Научно-исследовательская работа В.Х. Назаровой связана с изучением певческого искусства семейских Забайкалья [5]. Защитив в 2003 г. кандидатскую диссертацию, Венера Хушиновна продолжила исследования певческой культуры старообрядцев, поступив в очную докторантуру при МГИК. В настоящее время В.Х. Назарова занимает должность профессора кафедры русского народно-певческого искусства МГИК.

Существенных результатов в области исследования традиционной народной музыки достигла выпускница кафедры народного пения ВСГИК, а ныне кандидат искусствоведения, доцент Тамара Сергеевна Танганова. Большая часть научных трудов Т.С. Тангановой посвящена выявлению этнической специфики системы вокальной музыки устной традиции западных 
бурят - эхиритов и булагатов [6]. Полевые исследования по записи бурятских народных песен проводились в районах Бурятии и Иркутской области. Обладая большим опытом проведения научных исследований, Тамара Сергеевна настойчиво приобщала студентов к научной деятельности, руководила научным студенческим кружком кафедры. Среди подготовленных ею выпускников, продолжающих заниматься научной деятельностью кандидат искусствоведения О.Ш. Дарижапова (Заслуженный работник культуры АБАО).

Говоря о развитии в регионе народно-певческого образования нельзя не отметить в нем роли кафедры хорового дирижирования ВСГИК, в недрах которой сформировалось сначала отделение, а затем и самостоятельная кафедра народного пения. Первым, кто инициировал открытие в ВСГИК отделения по подготовке руководителей самодеятельных народно-хоровых коллективов, был заведующий кафедрой хорового дирижирования, профессор М.А. Белокрыс. В то время он также являлся художественным руководителем Забайкальского семейского народного хора, поэтому проблемы сохранения и развития в регионе народно-певческого искусства ему были хорошо понятны. Впоследствии кафедра хорового дирижирования на протяжении многих лет неизменно выступала в качестве партнера в подготовке руководителей самодеятельных народно-хоровых коллективов. Многие специалисты кафедры вели у «народников» учебные занятия по дирижированию, чтению хоровых партитур, хоровой аранжировке. Среди них А.И. Аштаев (Заслуженный работник высшей школы РФ, профессор), М.А. Ербахаева (Заслуженный работник культуры РБ), Ю.А. Банеев, Т.Г. Балханова и др.

По мере подготовки руководителей самодеятельных народнохоровых коллективов внутри кафедры народного пения ВСГИК сформировалось еще одно направление - школа игры на русских народных духовых инструментах Восточно-Сибирского региона. Основателем ее стал Сергей Николаевич Стефанов (Заслуженный работник культуры РБ, ст. преподаватель), в прошлом артист фольклорного ансамбля «Забава», мастер-самоучка по изготовлению русских народных духовых и шумовых инструментов. Обучение студентов игре на народных музыкальных инструментах фольклорной традиции осуществлялось в русле повсеместно сложившейся практики подготовки руководителей народных хоров, владеющих основами традиционного инструментального исполнительства и применения инструментов в репетиционной и концертно-исполнительской работе с народнопевческими коллективами.

С 2009 г. преподавание народных музыкальных инструментов фольклорной традиции продолжил Олег Геннадьевич Шаренда (Заслуженный работник культуры РБ, ст. преподаватель). Еще до прихода на педагогическую деятельность в Институт, О.Г. Шаренда зарекомендовал себя как опытный педагог, талантливый исполнитель, композитор и аранжировщик. Им написаны десятки произведений для народных и академических инструментов, для ансамблей и оркестров русских и бурятских народных инструментов. Ныне Олег Геннадьевич является художественным руководителем творческо-исполнительской лаборатории ВСГИК «Ансамбль народной му- 
зыки и танца «Сибирский сувенир», успешно совмещая художественнотворческую и педагогическую деятельность (преподает учебные дисциплины «Народные музыкальные инструменты», «Аранжировка народных песен», «Изучение концертного и педагогического репертуара»).

Новый этап в истории кафедры начался с 2009 г., когда после ряда реорганизационных мероприятий, проведенных в вузе, кафедра народного пения была переименована в кафедру народно-певческого искусства. В немалой степени этому способствовал переход от ГОС ВПО по специальности 053000 «Народное художественное творчество» на ФГОС ВПО третьего поколения по направлению 53.03.04 «Искусство народного пения», в соответствии с которым кафедра начала осуществлять подготовку бакалавров по профилям «Хоровое народное пение» и «Сольное народное пение».

В это же время заведующим кафедрой был назначен Николай Иванович Рещиков (Заслуженный работник культуры РБ, доцент). Будучи одним из первых выпускников, окончивших отделение народного хора ВСГИК, Н.И. Рещиков всю профессиональную деятельность посвятил развитию регионального народно-певческого искусства. Он - автор многих научных, учебно-методических и творческих работ, участник научно-практических и научно-методических конференций [7].

Переход на ФГОС ВПО по направлению 53.03.04 «Искусство народного пения» и реализация образовательной программы по профилю «Сольное народное пение» стали весьма непростыми задачами для кафедры, т.к. все предыдущие годы во ВСГИК осуществлялась подготовка исключительно руководителей народно-хоровых коллективов. В связи с этим пришлось в сжатые сроки решать целый ряд учебных, учебно-методических, организационных и кадровых вопросов. Потребовались разработка и внедрение новых учебных дисциплин, специальных курсов, учебных и производственных практик.

Неоценимую помощь в их решении оказали Т.А. Зырянова (Заслуженная артистка РБ, художественный руководитель народного ансамбля песни и танца «Раздолье»), О.Г. Шаренда (Заслуженный работник культуры РБ), Т.С. Кузнецова, С.Н. Перелыгина, В.С. Рещикова (Заслуженный работник культуры РБ), С.Ц. Маншеева, Е.Н. Мосохова, О.В. Золотарева, Л.Е. Кириллова, концертмейстеры П.Н. Дружинин, А.Г. Кузнецов и Г.Н. Хасанова. Огромный вклад в развитие нового направления подготовки внесла Е.О. Засимова (Заслуженный деятель искусств РФ, профессор кафедры сольного народного пения МГИК), щедро делясь своими знаниями, умениями и богатым практическим опытом обучения студентов сольному народному пению. Общее руководство образовательной программой по направлению 53.03.04 Искусство народного пения взял на себя Н.И. Рещиков.

Результат совместных усилий не заставил себя ждать. За последнее десятилетие подготовлено 38 выпускников, реализованы десятки научных, учебно-методических и творческих работ. Значительные успехи в области концертного исполнительства достигнуты старшим преподавателем Т.А. Зыряновой, подготовившей ряд творческих мероприятий, среди которых 
сольные концерты студенток М. Кравченко и М. Пивоварчик. Обе исполнительницы, а также вокальный квартет «Багряница», созданный из студентов отделения, под руководством Т.А. Зыряновой становились лауреатами международных и региональных конкурсов исполнителей народной песни. В настоящее время Т.А. Зырянова ведет учебные занятия по сольному и ансамблевому пению, является хормейстером вокальной группы ТИЛ ВСГИК «Ансамбль народной музыки и танца «Сибирский сувенир».

В рамках исполнительской практики студенты ежегодно принимают участие в различных творческих мероприятиях. С большим успехом прошли отчетные концерты «Песни - крылья России», «Когда поет душа, весь мир вокруг прекрасен!», «С Россией в сердце», «Пусть будет так!». Сольные концертные программы представили городской публике студенты отделения сольного народного пения Дарья Размахнина (класс доцента Г.М. Евтушенко, руководитель проекта - О. Шаренда), В. Соломенникова (класс доцента Н.И. Рещикова), Сайзана и Сай-Суу Саая (класс доцента С.Ц. Маншеевой). На Международном конкурсе-фестивале детского и молодежного творчества «Преображение» в г. Санкт-Петербург М. Кравченко (класс Засл. артистки РБ Т.А. Зыряновой) получила звание лауреата I степени. Дипломантом IX Всероссийского конкурса исполнителей народной песни им. Л.А. Руслановой (г. Саратов) стала В. Соломенникова, ныне продолжающая обучение в РАМ им. Гнесиных по программе магистратуры. Обладателем диплома II степени на IV Всероссийском фестивале-конкурсе эстрады «Байкал art-спектр» является О. Вологжина (класс Засл. артистки РБ Т.А. Зыряновой и Засл. работника культуры РБ О.Г. Шаренда).

Сегодня, оглядываясь назад, трудно переоценить роль народнопевческого образования, осуществляемого ВСГИК, в развитии музыкального искусства и народного художественного творчества Восточной Сибири и Забайкалья. Более 300 выпускников кафедры осуществляют в регионе и за его пределами музыкально-исполнительскую, педагогическую, культурнопросветительскую деятельность. Многие из них удостоены почетных званий российского и регионального уровня. Среди них Е. Баранова (Заслуженная артистка РБ), Г. Даренских (Заслуженная артистка РФ), Т. Зырянова (Заслуженная артистка РБ), Р. Лопатин (Заслуженный деятель искусств Заб. края), А. Мозгунова (Заслуженный деятель искусств Забайкальского края), А. Нечаев (Заслуженный артист РБ), Т. Пантелеева (Заслуженная артистка РБ), Н. Рещиков (Заслуженный работник культуры РБ), Ж. Сидинкина (Народная артистка РБ) и др.

В числе выпускников - известные деятели культуры, искусства и образования: директор Государственного национального театра песни и танца «Амар сайн» О.Ш. Дарижапова (Заслуженный работник культуры АБАО), зав. сектором русского фольклора РЦНТ В.Н. Долженко (Заслуженный работник культуры РБ), зам. директора РЦНТ, «Лидер культуры-2014» С.Д. Доржиев (Заслуженный работник культуры РБ), главный хормейстер Государственного ансамбля песни и пляски «Забайкальские казаки» С.Н. Кириллов (Заслуженный работник культуры 
Забайкальского края), ведущий специалист Центра духовной культуры «Арчы Дьиэтэ», отличник культуры Республики Саха Б.Н. Михайлов (Заслуженный работник культуры Республики Саха), директор Забайкальского краевого училища культуры А.И. Рюмкин (обладатель премии Правительства РФ «Душа России»), солистка московской фолькгруппы «Слобода», лауреат всероссийских и международных конкурсов $\mathrm{T}$. Ларина, солист муниципального Театра народной музыки и танца «Забава» А. Адианов, преподаватели учебных заведений СПО - Л.М. Егорова, О.В. Золотарева, Т.В. Лущинская, О.Н. Пакулова, Ж.Ц. Цынгуева и др.

Многие выпускники являются артистами профессиональных творческих коллективов, таких как ГУК Театр национальных культур «Забайкальские узоры» (г. Чита), ГУК Ансамбль песни и пляски «Забайкальские казаки» (г. Чита), Муниципальный фольклорный Театр «Забайкалье» (г. Чита), Бурятский государственный национальный Театр песни и танца «Байкал» (г. Улан-Удэ), Тувинский государственный ансамбль песни и танца «Саяны» (г. Кызыл), Муниципальный театр народной музыки и танца «Забава» (г. Улан-Удэ) и др.

Значительная часть выпускников является руководителями любительских вокально-хоровых коллективов, фольклорных ансамблей, детских художественных коллективов и студий. Некоторые коллективы, созданные выпускниками кафедры, стали своеобразными школами по приобщению детей и юношества к духовным ценностям традиционной народной культуры. Это образцовый фольклорный ансамбль «Забавушка» ГКЦ г. Улан-Удэ, студия народного пения «Потешки» ГДДЮТ, образцовый ансамбль семейской песни «Черпачок» с. Тарбагатай, ансамбль казачьей песни «Задоринки» п. Селенгинск и др.

Таким образом, в современных, непростых условиях реформирования российского образования Восточно-Сибирским государственным институтом культуры сохраняется и обеспечивается дальнейшее развитие регионального народно-певческого образования. В вузе разработана и принята Концепция развития ФГБОУ ВО ВСГИК до 2025 г., которая призвана обеспечить выполнение стратегических целей учебного заведения - вхождение в группу инновационных образовательных учреждений культуры и искусств России и международного сообщества посредством обеспечения высокого качества подготовки специалистов сферы культуры и искусства. Концепция открывает широкие перспективы продвижения искусства народного пения на качественно новый уровень, что соответствует задачам сохранения и развития национальной культуры России.

\section{Примечания}

1. Медведева М. В. История и перспективы развития народнопевческого искусства в России: «гнесинская» школа народного пения // Проблемы и перспективы развития народно-певческого исполнительства и образования в России : к 100-летию Нар. артистки СССР, проф. Н. К. Мешко и 50-летию народно-певческого образования в России : по материалам Все- 
рос. науч.-практ. конф. в рамках фестиваля-конкурса «Вечные истоки». М., 2017. C. 13-28.

2. Каргин А. С., Новожилов В. В. Народно-певческое образование в России: история и современность // Народно-певческое образование в России : сб. материалов науч.-практ. конф. М., 2009. С. 5-18.

3. Цветок в янтаре : песни семейских Забайкалья / сост., предисл., примеч.: В. С. Рещикова, Н. И. Рещиков. Улан-Удэ, 2007. 152 с.

4. Евтушенко Г. М. Отчий край : сборник авторских произведений аранжировок и обработок. Улан-Удэ, 2006. 98 с.

5. Назарова В. Х. Песенная традиция семейских Забайкалья. УланУдэ, 2001. 42 с. ; Назарова В. Х. Певческое искусство старообрядцев Забайкалья. Улан-Удэ, 2008. 170 с. ; Назарова В. Х. Источники исследования песенной культуры старообрядцев Забайкалья // Вестник Московского гос. унта культуры и искусств. 2009. № 3. С. 56-64.

6. Танганова Т. С. Застольные песни бурят Предбайкалья // Этнические процессы и традиционная культура. М. ; Улан-Удэ, 2005. С. 181-196 ; Танганова Т. С. Общая характеристика песенной культуры бурят Предбайкалья // Песенный фольклор в контексте традиционной культуры : материалы междунар. науч.-практ. конф. М., 2009. С. 53-60 ; Танганова Т. С. Певческое искусство бурят Предбайкалья. Улан-Удэ, 2011. 164 с.

7. Рещиков Н. И. Пространственно-временные парадигмы в традиционной культуре старообрядцев (семейских) Забайкалья // Старообрядчество: история и современность, местные традиции, русские и зарубежные связи : материалы 5 Междунар. науч.-практ. конф. (31 мая-1 июня 2007 г., г. УланУдэ). Улан-Удэ, 2007. С. 448-455 ; Рещиков Н. И. К проблеме изучения современного состояния традиционной праздничной культуры семейских // Культурное пространство Восточной Сибири и Монголии: региональные особенности и международное сотрудничество : материалы 7 междунар. науч.-практ. конф. Улан-Удэ, 2017. С. 143-151 ; Рещиков Н. И. История народно-певческого исполнительства : учеб.-метод. пособие. Улан-Удэ : Изд.полигр. комплекс ВСГИК, 2018. 88 с.

\section{References}

1. Medvedeva M. V. Istorija i perspektivy razvitija narodno-pevcheskogo iskusstva v Rossii: «gnesinskaja» shkola narodnogo penija [History and perspectives of the folk singing art department in Russia: "Gnesin's" school of folk singing // Problemy i perspektivy razvitija narodno-pevcheskogo iskusstva v Rossii: $\mathrm{k}$ 100-letiju Nar. artistki SSSR, prof. N. K. Meshko i 50-letiju narodnopevcheskogo obrazovanija v Rossii : po materialam Vseros. nauch.-prakt. conf. v ramkakh festivalja-konkursa «Vechnije istoki» [Problems and perspectives of the development of folk singing performance and education in Russia: to the $100^{\text {th }}$ anniversary of the People's artist of the USSR, prof. N. K. Meshko and the $50^{\text {th }}$ anniversary of folk singing education in Russia : on the materials of All-Russian scient. pract. conference within the framework of the festival-contest "Eternal sources"]. M., 2017. Pp. 13-28. [In Russ.]. 
2. Kargin A. S., Novozhilov V. V. Narodno-pevcheskoje obrazovanije v Rossii [Folk-singing education in Russia: history and modernity] // Narodnopevchekoje obrazovanije $\mathrm{v}$ Rossii : sb. materialov nauch.-prakt. konf. [Folksinging education in Russia : collection of the scient.-pract. conf. materials]. M., 2009. Pp. 5-18. [In Russ.].

3. Cvetok v jantare : pesni semejskikh Zabajkalja [Flower in amber : songs of the Old Believers of Transbaikalia] / comp., foreword and references: V. S. Reshchikova. N. I. Reshchikov. Ulan-Ude, 2007. 152 p. [In Russ.].

4. Yevtushenko G. M. Otchij kraj : sbornik avtorskikh proizvedenij aranzhirovok i obrabotok [Native land : collection of the author's arrangement and rendition works]. Ulan-Ude, 2006.98 p. [In Russ.].

5. Nazarova V. Kh. Pesennaja tradicija semejskikh Zabajkalja [Song tradition of the Old Believers of Transbaikalia]. Ulan-Ude, 2001. 42 p.; Nazarova V. Kh. Pevcheskoje iskusstvo staroobrjadcev Zabajkal'ja [The singing art of the Old Believers of Transbaikalia]. Ulan-Ude, 2008. 170 p. ; Nazarova V. Kh. Istochniki issledovanija pesennoj kul'tury staroobrjadcev Zabajkal'ja [The study sources of the song culture of the Old Believers of Transbaikalia] // Vestnik Moskovskogo gos. un-ta kul'tury i iskusstv [Bulletin of Moscow state university of culture and arts]. 2009. No. 3. Pp. 56-64. [In Russ.].

6. Tanganova T. S. Zastol'nije pesni burjat Predbajkal'ja [Buryat songs at the table of Prebaikalia] // Etnicheskije processy i tradicionnaja kul'tura [Ethnic processes and traditional culture]. M. ; Ulan-Ude, 2005. Pp. 181-196 ; Tanganova T. S. Obshchaja kharakteristika pesennoj kul'tury burjat Predbajkal'ja [General characteristics of the song culture of the Buryats of Prebaikalia] // Pesennij fol'klor $\mathrm{v}$ kontekste tradicionnoj kul'tury : materialy mezhdunar. nauch.-prakt. konf. [Song folklore in the context of traditional culture : materials of the intern. scient.-practical conf.] M., 2009. Pp. 53-60 ; Tanganova T. S. Pevcheskoje iskusstvo burjat Predbajkal'ja [The singing art of the Buryats of Prebaikalia]. UlanUde, 2011. 164 p. [In Russ.].

7. Reshchikov N. I. Prostransvenno-vremennyje paradigmy v tradicionnoj kul'ture staroobrjadcev [Space-time paradigms in the traditional culture of the Old Believers of Transbaikalia // Staroobrjadchestvo: istorija i sovremennost', mestnyje tradicii, russkije i zarubezhnyje svjazi : materialy 5 Mezhdunar. nauch.prakt. konf. (31 maja-1 ijunja 2007 goda, g. Ulan-Ude [Old Believers: history and modernity, local traditions, Russian and foreign relations : materials of the $5^{\text {th }}$ Intern. scient. pract. conf. (May 31 - June 1, 2007, Ulan-Ude). Ulan-Ude, 2007. Pp. 448-455 ; Reshchikov N. I. K probleme izuchenija sovremennogo sostojanija tradicionnoj prazdnichnoj kul'tury semejskikh [To the problem of studying the current condition of the traditional festive culture of the Old Believers] // Kul'turnoje prostranstvo Vostochnoj Sibiri i Mongolii: regional'nyje osobennosti i mezhdunarodnoje sotrudnichestvo [Cultural space of Eastern Siberia and Mongolia: regional peculiarities and international cooperation : proceedings of the $7^{\text {th }}$ intern. scient. pract. conf.] Ulan-Ude, 2017. Pp. 143-15 ; Reshchikov N. I. Istorija narodno-pevcheskogo ispolnitel'stva : ucheb.-metod. posobije [History of folk singing : a teaching manual]. Ulan-Ude, 2018. [In Russ.]. 


\section{Маншеева С. Ц.}

Mansheeva S. Ts.

\section{ИЗ ОПЫТА ТВОРЧЕСКОЙ ДЕЯТЕЛЬНОСТИ СТУДЕНЧЕСКОГО ФОЛЬКЛОРНОГО АНСАМБЛЯ «УЛЬГЭР» \\ FROM THE EXPERIENCE OF THE CREATIVE ACTIVITY OF THE STUDENTS' FOLK ENSEMBLE «ULGER»}

В статье рассмотрена творческая деятельность студенческого фольклорного ансамбля «Ульгэр», действующего при кафедре этнологии и народной художественной культуры ФГБОУ ВО «Восточно-Сибирский государственный институт культуры». Автор раскрывает специфику деятельности фольклорного ансамбля, определяет значимость фольклорного коллектива, способствующего сохранению и популяризации традиционного культурного наследия, формированию национального самосознания молодого поколения. Развитие талантов, знание традиций народной культуры, этнографическая достоверность - все это позволяет студенческому ансамблю успешно представлять бурятский народ как внутри нашего многонационального государства, так и за рубежом.

The article considers the creative activity of the students' folklore ensemble "Ulger" performing under the guidance of the Department of Ethnology and Folk Art Culture of the FSBEI HE "East Siberian state Institute of culture". The author reveals the specifics of the folklore ensemble activities, determines the importance of the folklore group which contributes to the preservation and popularization of the traditional cultural heritage, formation of the national identity of the younger generation. The development of talents, knowledge of the traditions of folk culture, ethnographic authenticity allow the students' ensemble to represent the Buryat people successfully both within our multinational state and abroad.

Ключевые слова: фольклор, фольклорный ансамбль, народная песня, творчество, творческая деятельность, традиционная культура бурят.

Keywords: folklore, folklore ensemble, folk song, creativity, creative activity, traditional Buryat culture.

Негативным последствием глобализационных и интеграционных процессов в современном мире является унификация культур, спровоцировавшая опасность исчезновения этнографического разнообразия. Под угрозой многие виды и жанры традиционной культуры. Поэтому неудивительно, что в последние десятилетия исследовательский интерес к культурному наследию народа неуклонно растет. Данная тенденция обусловлена особой ценностью фольклора, который отражает жизненное мировоззрение, многовековую мудрость народа. В нем современный человек, далекий от первоначальных истоков бытия, может найти средство для решения многих насущных задач: от самовыражения, реализации своих творческих потребностей 
до воспитания и развития подрастающего поколения. Поэтому важнейшей задачей современности является сохранение, восстановление и передача потомкам народных обычаев, праздников, сопутствующих им обрядов, традиционного декоративно-прикладного и изобразительного искусства. Необходимо более чуткое отношение к памятникам истории и искусства, к народному художественному творчеству, содержащему в себе бесценные знания, мудрость, позволяющему нам получить представление об истории народа, его мыслях и чаяниях. Вся картина народной жизни, духовные, нравственные аспекты бытия ярко представлены в произведениях устного народного творчества.

Такая характерная особенность фольклора, как локальность находит отражение в работе любого фольклорного коллектива. Локальность подразумевает «различимость местных (локальных) песенных традиций, мелодических напевов и других параметров» [1]. Наряду с этим, нельзя отрицать и наличие общих свойств и характеристик.

Одним из ключевых моментов работы творческого коллектива является подбор репертуара. В студенческом фольклорном ансамбле «Ульгэр» для пополнения репертуара используется электронная база РЦНТ «Бурятские народные песни» [4]. Данная база регулярно обновляется, в неё по результатам фольклорных экспедиций добавляются произведения устного народного творчества. Таким образом и происходит учет региональных особенностей и колорита различных локальных художественных традиций.

Вся деятельность творческого коллектива нацелена на изучение, сохранение и популяризацию традиционной культуры бурят посредством творческо-исполнительской деятельности участников. Основная цель студенческого ансамбля состоит в самореализации личности через совместную художественно-творческую деятельность. Освоение студентами бурятских народных певческих традиций способствует сохранению и пропаганде народного художественного творчества.

В начале творческого пути ансамбля, у истоков стояли Валентина Цыденовна Дамбуева и Дашинима Санжиевич Дугаров. Они в свое время собрали бесценный фольклорный материал со всей этнической Бурятии, на основе которого воссоздано множество шедевров бурятского песенного наследия. Дашинима Санжиевич является автором множества трудов по изучению бурятского музыкального фольклора.

С 2006 года ансамблем руководит Соёлма Цыдыповна Маншеева. Будучи талантливой исполнительницей народных песен (знатоком фольклора), Соёлма Цыдыповна старается передать ученикам все богатство народных певческих традиций.

Ансамблю «Ульгэр» присуща особая форма музыкального исполнительства, которую отличает самобытность, достоверность интерпретации и высокий уровень мастерства. В репертуаре коллектива представлены образцы фольклорного наследия как районов Республики Бурятия, так и Забайкальского края и Иркутской области. Кроме того, в него вошли и произведения устного народного творчества шэнэхэнских бурят. Это эпические и ехорные напевы, ритуально-обрядовые действа, молодежные игры, малые 
поэтические и прозаические жанры устного народного творчества, лирические, исторические, застольные, санные, кумысные песни и др. Неизменный успех у публики имеют обрядовые постановки, сюжетом которых служат эпизоды из календарного цикла или жизни человека от рождения до смерти. Зрителям также интересны бурятские традиционные игры. Многие игры сопровождаются текстом и мелодией, такие как «Алта нюулга», «Бээлэй нюулга», «Шоно тарбагашааха», «Дуу андалдаан» и многие другие.

Естественная, непринужденная и этнографически достоверная манера исполнения достигается благодаря регулярным занятиям и участию коллектива в различных творческих мероприятиях, организуемых в институте, городе, республике. Сценическое мастерство участников оттачивается средствами фольклорно-театрализованных представлений, праздников, концертных, конкурсно-фестивальных выступлений [3].

Большинство фольклорных праздников Бурятии проходит при участии студенческого ансамбля «Ульгэр». В рамках мероприятий, посвященных традиционному празднику Сагаалган, коллектив ежегодно дает мастерклассы по ёхору, студенты проводят в общеобразовательных школах занятия по обучению младших школьников бурятским народным танцам, песням и играм. Кроме того, коллектив уделяет большое внимание благотворительным проектам, которые предоставляют возможность больным детям получить дорогостоящее лечение.

Гастрольные туры ансамбля, помимо районов республики, охватывают соседние и другие регионы страны, выступления за рубежом. О том, что в целом творческая жизнь коллектива находится на подъеме, свидетельствуют такие результаты как различные титулы, награды, признания на конкурсах и фестивалях разных уровней.

Особую гордость ансамбля составляют его солисты, исполнители народного вокала, такие как Лайжатова Виктория, Лауреат I степени IV Международного конкурса-фестиваля «Зимняя соната-2020», V Международного конкурса «Таланты России-2020». Также на конкурс «Таланты России-2020» в номинации «Народный вокал» творческую работу предоставила Батуева Баина и завоевала Диплом Лауреата І степени. Цыреторова Сэлмэг участвовала в Международном конкурсе «Ступеньки к успеху-2020» и стала Лауреатом II степени. Активное участие в вышеперечисленных мероприятиях принимала Эрдынеева Валентина, Лауреат II степени конкурса-фестиваля «Зимняя соната-2020» и конкурса «Ступеньки к успеху-2020». Кроме того, она стала Лауреатом I степени Международного фестиваля-конкурса «Солнечный круг-2020».

Участникам ансамбля особенно запомнилась поездка в Финляндию на «Hollo\&Martta International Folklore Festival», который проходил в г. Холлола с 29 октября по 5 ноября 2017 года. В XIV Международном фестивале народного танца и музыки принимало участие более 180 коллективов. Ансамбль к данной поездке подготовился основательно, серьезно проработали репертуар, дополнив его фольклорным материалом свадебной обрядности западных бурят. Были продемонстрированы игры развлекательного характера и малые жанры бурятского фольклора. Исполнители горлового пения вы- 
звали бурю эмоций у зрителей. Также горячий отклик у зрительного зала получил солнечный танец бурятского народа «Ёхор». В целом, вся программа ансамбля была оценена по достоинству, коллектив завоевал Приз зрительских симпатий. Исполнительный директор господин Аймо Хентинен (Aimo Hentinen) по итогам особо отметил высокий уровень мастерства участников ансамбля [2].

Немаловажным моментом в характеристике деятельности коллектива является то, что наряду с образовательной ведется и научноисследовательская работа. В сферу научных интересов попадают проблемы возрождения и сохранения локальных диалектных и стилевых особенностей народной песенной и танцевальной культуры. Были предприняты ряд экспедиций по сбору полевого материала, по восстановлению обрядовопраздничных традиций. Научные исследования проводились в селах Нарсатуй и Хошун-Узур Мухоршибирского района, в селе Монды Тункинского района, в селе Санага Закаменского района Республики Бурятия, в селе Гунэй Агинского района Забайкальского края и других населенных пунктах данных регионов.

Таким образом, творческая деятельность студенческого фольклорного ансамбля «Ульгэр» способствует сохранению самобытной культуры бурят. Участники, сами успешно приобщаясь к фольклору в процессе освоения традиций народа, популяризируют бурятскую культуру в молодежной среде, также в целом в местном социуме. Студенты в рамках профориентационной работы кафедры этнологии и народной художественной культуры ВСГИК посещают общеобразовательные школы, средние специальные учебные заведения, учреждения дополнительного образования Республики Бурятия и соседних регионов, проводят беседы с учащимися. Демонстрация их таланта, умений, мастерства помогает школьникам осознать свой творческий потенциал, определиться с выбором будущей профессии.

Обширная конкурсно-фестивальная деятельность коллектива способствует пропаганде фольклорных традиций бурятского народа за пределами нашего региона, как внутри Российской Федерации, так и на международном уровне. В целом, демонстрируя образцы традиционного бурятского музыкального творчества, ансамбль «Ульгэр» вносит существенный вклад в дело сохранения традиционной культуры бурят.

\section{Примечания}

1. Самбуева С. Б., Гончикова М. Ц. Музыка бурят истоки и традиции : учеб. пособие. Улан-Удэ, 2013. С. 6.

2. ФГБОУ ВО Восточно-Сибирский государственный институт культуры. URL: https://www.vsgaki.ru/subdivisions/faculties/humanities-faculty-ofinformation/the-department-of-ethnology-and-folk-art-and-culture/ (дата обращения: 19.06.2020).

3. Маншеева С. Ц. Фольклорный ансамбль как фактор сохранения традиционной народной культуры (на примере студенческого фольклорного ансамбля «Ульгэр») // Сохранение, изучение и популяризация наследия: опыт участия и векторы развития : материалы всерос. с междунар. участием 
науч.-практ. конф. (18 апр. 2019 г., г. Улан-Удэ). Улан-Удэ : Изд.-полигр. комплекс ВСГИК, 2019. Т. 1. С. 258-261.

4. Электронная база «Буряад арадай дуунууд». Бурятские народные песни: по материалам фольклорных экспедиций. URL: http://xn-80aab7afbga0a3d.xn--p1ai/elektronnaya-baza-buryatskie-narodniepesni1/elektronnaya-baza-buryatskie-narodnie-pesni (дата обращения: 20.06.2020).

\section{References}

1. Sambueva S. B., Gonchikova M. Ts. Muzyka burjat istoki i tradicii : ucheb. posibije [Music of the Buryats origin and traditions : manual]. Ulan-Ude, 2013. P. 6. [In Russ.].

2. FGBOU VO Vostochno-Sibirskij gosudarstvennyj institut kul'tury
[FSBEI HE East-Siberian state institute of culture]. URL: https://www.vsgaki.ru/subdivisions/faculties/humanities-faculty-ofinformation/the-department-of-ethnology-and-folk-art-and-culture/ (19.06.2020). [In Russ.].

3. Mansheeva S. Ts. Fol'klornyj ansambl' kak factor sokhranenija tradicionnoj narodnoj kul'tury (na primere studencheskogo fol'klornogo ansamblja «Ul'ger» [Folk ensemble as a factor of preserving traditional folk culture (taking the students' ensemble «Ulger» as an example]) // Sokhranenije, izuchenije i populjarizacija nasledija: opyt uchastija i vektory razvitija : materialy vseros. $\mathrm{s}$ mezhdunar. uchastiem nauch. prakt. konf. (18 apr. 2019 g., Ulan-Ude) [Heritage preservation, study and popularization: the participation experience and vectors of development : materials of the All-Rus. scientific and practical conference with intern. participation (18 April 2019, Ulan-Ude)]. Ulan-Ude, 2019. V. 1. Pp. 258261. [In Russ.].

4. Elektronnaja baza «Буряад арадай дуунууд». Burjatskije narodnije pesni: po materialam fol'klornjkh ekspedicij [The electronic base «Буряад арадай дуунууд». The Buryat folk songs : on the materials of the folklore expeditions]. URL: $\quad$ http://xn--80aab7afbga0a3d.xn--p1ai/elektronnaya-baza-buryatskienarodnie-pesni1/elektronnaya-baza-buryatskie-narodnie-pesni (20.06.2020). [In Buryat]. 


\section{ВЕХИ И СУДЬБЫ}

DOI 10.31443/2541-8874-2020-3-15-148-164

УДК 378.6(091)(571.54-25)

Орлов Л. Г.

Orlov L. G.

Уважение к минувшему - вот черта, отделяющая образованность от дикости А.С. Пушкин

\section{ГОДЫ ВО ВСГИКЕ: ГЛАЗАМИ ОЧЕВИДЦА YEARS IN ESSIC: THE VIEW OF THE EYEWITNESS}

Статья посвящена воспоминаниям, связанным с вузом периода с 1973 по 2008 гг. Приводятся воспоминания о выдающихся ученых и педагогах, с которыми посчастливилось трудиться и дружить автору.

The article is devoted to the memories associated with the higher educational institution from 1973 to 2008. The memories about the outstanding scientists and teachers with whom the author was lucky to work and make friends are given.

Ключевые слова: институт культуры, преподаватели, история, выпускники.

Keywords: institute of culture, teachers, history, graduates.

Прошло уже почти полвека с того времени, когда в далеком 1973 году я переступил порог замечательного Восточно-Сибирского государственного института культуры и открывал его двери ровно 35 лет до 2008 года. Условно, да и не только условно, а по существу, по факту эти три с половиной десятка лет можно подразделить в равной мере на два периода - советский до начала 1990-х гг. и период так называемой демократической России, который как будто продолжается до текущих лет, демократический с большой натяжкой и сомнением. Конечно, тот или иной период наложили свой отпечаток на жизнь страны, ее людей, не стал исключением и наш вуз. Но мы здесь не беремся сопоставлять и сравнивать на примере жизни института эти времена, но скажем, что Россия вновь, уже второй раз, вступила в стадию буржуазного, капиталистического развития, которое напроч отрицалось в предыдущие времена. Многое чего пришлось увидеть, услышать в эти переходные времена, принять вольно или невольно собственное в них участие. Вот уж поистине правду говорят, что «не дай бог жить в эпоху перемен».

Приступая к составлению настоящих заметок, записок под характерным названием, которое обязывает, мы еще приведем здесь вторую русскую пословицу, что «самый ненадежный свидетель - это очевидец». Да, многие из нас бывали свидетелями, когда об одном и том же событии два очевидца говорят и высказывают противоположные суждения... 
В институт на работу я поступил по рекомендации знавших меня людей и принимался заведующим кафедрой истории Батуевым Бато Бадмаевичем - человеком более чем разумным, опытным, о котором сохраняю самые добрые и теплые воспоминания. Вскоре он защитил докторскую диссертацию и был едва ли не единственным профессором нашего вуза. Это позже, лет через 20-30 такие высокие научные ранги стали присваиваться здесь, в Улан-Удэ, да и повсюду, почти в массовом порядке и привели их к девальвации, что и следовало ожидать в условиях смутного времени.

Переход на работу в вуз - дело, конечно, нерядовое для каждого индивидуума, не исключая и автора этих строк. Ведь я поступал на должность рядового преподавателя кафедры истории, а уходил с должности директора школы №44 г. Улан-Удэ, а это значило понижение статуса, низкая зарплата. И сегодня на вопрос - следовало ли это делать? - склоняюсь к ответу - нет, не следовало. Но при всем при том, об институте культуры у меня остались добрые воспоминания: его людях, творческих и колоритных, с которыми работал бок о бок десятилетия, и конечно, о студентах. Такова эта суетная жизнь, в вечных противоположностях, сомнениях, и многое мы осознаем поздним умом, как говорил поэт.

Наши настоящие заметки - заметки частного человека, человека со стороны, давно отошедшего от служебных обязанностей и цель наша просто зафиксировать письменно, печатно то, что сохранилось в памяти от прошлого. Ведь быстротекущее время в своем поступательном и вечном движении неумолимо отодвигает прошлые события, образы людей, которые вершили историю вуза. В то же время в жизнь превозносятся новые ценности, новые представления об окружающей действительности и было бы несправедливо, если были бы забыты те, кто создавал вуз, способствовал его становлению.

Замечательный вклад в утверждение истории ВСГИК сделал в недавнем прошлом второй ректор института Сергей Иванович Никифоров, издавший книги «Виват, Академия», «Из личного архива» и другие. Он как ответственный по своему служебному положению и подлинный радетель и знаток института, рассказывает о становлении вуза, проблемах, которые разрешал педагогический коллектив в контексте тех исторических событий, которые переживала наша страна. Очень советуем нынешним поколениям педагогов и студентов открыть страницы этих изданий, автор которых был одним из главных действующих лиц своего времени.

Восточно-Сибирский государственный институт культуры был третьим в стране среди вузов подобного профиля: первый вуз культуры был создан в Ленинграде, второй в Москве. Эти два вуза Центральной России и пришли на помощь при организации своего собрата за Байкалом. Посланцы этих вузов, многие из которых приехали в Улан-Удэ по целевому направлению - библиотекари, музыканты, хоровики, хореографы способствовали тому, что ВСГИК почти сразу встал в один ряд со столичными вузами. Необходимо отметить, что наш вуз создавался как библиотечный по своему профилю. Многие из этих посланцев, выполнив свою миссию, оставили наш город, другие еще работали. На моем слуху, на устах тех, кто знал посланцев, были И.Г. Моргенштерн, Н.С. Карташев - будущий директор Государ- 
ственной библиотеки СССР им. В.И. Ленина. Забыта А.В. Морозова, Д.С. Марков. При мне еще работал почти легендарный Л.А. Бройтман, Г.Н. Тубельская, Н.Ф. Новичкова, Д.А. Гольштейн, З.К. Померко. Пусть все эти заслуженные педагоги, ученые останутся в истории на этих страницах. Называя имена посланцев издалека поименно, поставивших институт культуры на ноги, мы здесь вспомним в общем порядке, что в России не раз бывало, когда Центр, Москва не оставляли без внимания свои окраины, провинции, способствовало их развитию на общегосударственном уровне. В институт уже приходили и приходили не менее замечательные уроженцы наших мест, педагоги первого поколения: А.А. Белоусов, Г.А. Иофин, Н.С. Кузнецкий, М.М. Клочихина, А.И. Устинович, и добрые друзья-сослуживцы Б.3. Юшин, Н.П. Конев, А.Г. Изосимова, В.Н. Калаганская. И сегодня так и видятся их дорогие лица, образы и хочется сказать о них, ушедших от нас, бесконечно много добрых слов. Но мы только скорбно склоним голову в честь их имён и памяти вечной за их дела и заслуги.

Однако, по служебным делам и товарищеским отношениям мне ближе всего были, конечно, мои историки кафедры. В целом, надо наперёд сказать, что случившиеся в стране общегосударственные пособия, как пресловутая перестройка, распад СССР, межнациональные конфликты, ликвидация мировой системы социализма, скажем по большому счету, более всего и больнее всего коснулись нашей прошлой и текущей истории. Вот тогда-то и вошла в обиход поговорка «О нашем непредсказуемом прошлом», с развенчанием которого и пошли все пертурбации. Понятно, что в умственном, идейном отношении все эти непредсказуемые процессы не остались в стороне от историков. Некоторые из моих товарищей по кафедре, чья научнопедагогическая деятельность была связана напрямую с историей Коммунистической партии, переживали все «новшества» очень болезненно. Заметим в этой связи, что история всегда была наукой, предметом политическим и находилась под опекой любой господствующей в тот или иной период государственной власти, требуя всегда, как и сейчас трактовать историю с позиции собственных интересов, выгоды. Историкам всегда отводилась роль быть на стороне главенствующих политических сил. История никогда не писалась по-другому со времён Древнего Рима. Это большой, сложный вопрос, который нельзя объяснить каким-то априори умышленным обманом.

В начале 1990-х годов из программ преподавания были исключены такие предметы, как «Научный коммунизм», «История Коммунистической партии Советского Союза» и другие. В эти непростые годы перехода от одной общественной формации к другой очень болезненно, в том числе и автору этих строк, были восприняты трагические события ухода в прошлое государственных символов - герба, флага, гимна и других знаковых атрибутов советских лет, на которых выросли и сформировались историки моей кафедры. А на ней работали профессионалы, которых в другом качестве просто невозможно было представить. Многие из них были 1920-х годов рождения, некоторые из них, как Б. Батуев, М. Шмулевич были участниками Великой Отечественной войны 1941-1945 гг. Историки - это не физики или математики, законы которых остаются во все времена неизменны, историк 
так или иначе должен отвечать своему времени, быть толкователем тех взглядов и идей, которыми и живет это общество. Но далее скажем о своих товарищах, их человеческих качествах, особенностях характера. Каждый из них имел свою индивидуальность и выделялся, скажем так, «лицом необщим выражения».

Более десяти лет назад в институте силами кафедры истории проводилась памятная научная конференция «Батуевские чтения», где автор этих строк представил материал под характерным названием «Такими их знали при жизни». Цель той статьи была очень проста и понятна - сказать благодарственное слово о своих старших товарищах, с которыми много лет работал бок о бок. На страницах предстали Б.Б. Батуев, Б.З. Юшин, С.С. Бадмацыренов, М.М. Шмулевич, М.И. Лабыгин, К.Х. Халзанов, Ю.И. Рубцов. Именно они много сделали для развития и утверждения истории в институте культуры как науки и предмета преподавания. И это было бы крайне несправедливо забыть их имена на рубеже 60-летия ВСГИКа. Именно этими побуждениями руководствуемся мы и сейчас, говоря печатно благодарственные слова.

Когда вспоминаешь своих старших коллег, то в первую очередь хочется сказать не об их строго преподавательской деятельности, а и о некоторых человеческих качествах. И здесь не хотелось бы в порядке очередности придерживаться некой субординации, но все же начнем с имени заведующего кафедрой, что соответствует смыслу и логике нашего повествования.

Вспоминая совместную многолетнюю работу с Бато Батуевичем Батуевым, в первую очередь хочется сказать, что с ним было легко сотрудничать и как с человеком, и как с заведующим: никогда не ощущалось какогото принуждения с его стороны, мелочной придирчивости или менторского тона - неотъемлемой части многих недалеких чинуш. Он всегда делал то, что говорил и говорил то, что делал. Это сразу исключало всякую закулисную заглазность, двусмысленность. И при всем при том для всех нас он оставался авторитетом, слово которого имело должное значение. Надо понять, что подобная линия отношений с его стороны не была следствием какой-то осмысленности, заданности, а все было естественно и определялось его личным характером и, конечно, многолетним опытом работы с людьми. Скажем так по-канцелярски, Б.Б. Батуев был одарен ясным умом и характером крупного ученого, которому излишние мелочи претили по сути.

Как видит читатель, подобные высокие слова мы говорим спустя много лет после того времени, когда сообща сотрудничали и потому эти суждения о личности доктора исторических наук, профессора Б. Батуева должны быть приняты со всей полнотой искренности.

В условиях общественно-политического кризиса Б.Батуев, как историк, не мог оставаться безучастным ко всему, что происходило вокруг, в условиях смены общественно-экономической формации, когда уходил социализм с его базовыми ценностями на власть, собственность, менялась система идеологических представлений. Мы не будем касаться смысла этих изменений, но скажем, что Бато Бадмаевич переживал это глубоко, болезненно, но все равно достойно и с честью реагировал на новые обстоятельства жизни. 
Советский Союз был многонациональным государством, как и Россия. А национальный вопрос, то есть взаимоотношения народов, проживающих в пределах того или иного государства, всегда бывает непрост и требует разумного внимания. Ведь не случайно, СССР распался в начале 1990-х гг., строго по границам национальных образований, по границам союзных республик. Масло в этот костер добавили опрометчивые и недальновидные слова высокого политического деятеля, сказавшего «Берите суверенитета столько, сколько проглотите». Все это привело к радикализму в сфере национальных отношений, которые требуют особого внимания, но не столь провокационного понимания их. Не обошли эти проблемы и здешние забайкальские края, Бурятию в том числе. Ряд местных деятелей, в том числе и вузовской профессуры, поддались на призывы о сепаратизме и стали усиленно реанимировать тезис «о собирании бурятских земель», предъявлять государственным властям требование о признании бурят репрессированным народом, отмены государственных актов 1920-1930-х годов о панмонголизме, старомонгольской графике и другие.

К чести, Б. Батуева, он не посчитал нужным присоединять свой голос по отстаиванию этих утративших историческую актуальность политических вопросов. В своей монографии «Мария Михайловна Сахьянова» (УланУдэ, 1992 г.) он прямо высказал свое мнение как гражданин и ученый по поводу воссоединения бурятских округов, расположенных в соседних регионах, что «в 1992 году большинство населения автономных округов, в том числе и бурятское, высказывается против объединения с Бурятской республикой в настоящее время», показывает глубокие основания хозяйственноэкономического, территориального тяготения их к Иркутской и Читинской областям [1, с. 53].

Не должно быть забыто имя одаренного педагога, лектора, Заслуженного деятеля культуры Бурятии Юшина Бориса Зиновьевича. Здесь к месту и априори скажем, что нам посчастливилось, еще до совместной работы в Восточно-Сибирском государственном институте культуры, познакомиться в 1964 году во время совместной поездки лекторовмеждународников от Бурятии на межзональный семинар в город Владивосток, когда я еще проходил четвертый курс обучения в Бурятском государственном пединституте им. Д. Банзарова и одновременно выступал с публичными лекциями на предприятиях и в организациях г. Улан-Удэ. А Борис Зиновьевич был одним из основных ведущих по этой проблематике на местном телевидении и радио. В моей памяти образ Юшина привлекал личным обаянием, не показной, а внутренней интеллигентностью, добродушием, которое исходило от него и, конечно, скромностью и порядочностью. Такие высокие оценочные суждения об одном из замечательных педагогов, ученых ВСГИКа говорим здесь на основании впечатлений, которые сохранились в памяти спустя много десятилетий. Как подчас приходится сожалеть сегодня, что мы уже не имеем возможности сполна оценить столь достойных людей, нас окружавших. Особенно хочется отметить Бориса Зиновьевича, как замечательного лектора: студенты никогда не забудут стройность его рассуждений, логическую ясность, убедительную доказательность, наполненную так- 
том и научной достоверностью. В семейном архиве Юшиных приходилось видеть восторженные письменные отзывы его слушателей-студентов.

Каждый из коллег-историков так или иначе имел свою индивидуальную особенность. Долгое время, почти до последних дней своей жизни работал на кафедре профессор Бадмацыренов Сосорон Санжаевич. Он был, пожалуй, самым старшим из всех своих коллег. Этот заслуженный и известный человек долгое время до ВСГАКи проработал в должности министра просвещения Республики Бурятия, имел правительственные отличия, научные труды по вопросам педагогики, школьного воспитания. Однако, при всем при том, он, как знаток жизни во всех ее проявлениях, отличался здоровым и хорошим юмором, был доступен в общении со всеми, особенно со студентами, которые с уважением за глаза звали его именем римского исторического деятеля - кого, - можно догадаться по созвучию с именем - Цицерон. Для полноты картины отметим, что он был выдающимся оратором, почти легендой в этой ипостаси, а Сосорон Санжеевич в определенном месте своих публичных лекций нередко вопрошал аудиторию так: «Вы что думаете, коммунизм придет к Вам, тук-тук в дверь? Нет! Для этого много нужно работать самим!» И при этом главное слово в этой тираде «коммунизм» он произносил с некоторым акцентом и вместо буквы «К» произносил ее как «Х» и таким образом, в памяти слушателей подобные сюжеты оставались надолго. Многое в условиях изменившейся общественно-политической обстановки, слушаются и оцениваются по-другому. Интересно, что одна из любезно подаренных мне его книг так и называлась «Труд - основа коммунистического воспитания школьников» [2]. Вот как меняются времена, а вместе с ними и мы - «человеки».

Отдавая дань памяти своим замечательным старшим друзьямтоварищам, скажем признательные слова незабываемой и одаренной личности Михаила Моисеевича Шмулевича. Его книга-брошюра «ТроицкоСеленгинский монастырь» неизменно находится на моем столе и как справочник, и как занимательное и достойное чтение [3]. Он работал по проблемам Западного Забайкалья и позднее его близкие и родственники издали монографию на эту тему [4]. Своей научной темой он был одержим и не раз приходилось слышать его рассказы о поисках материала и скажем здесь, не знаем к месту ли, что свою жизненную кончину он встретил в читальном зале Государственного архива Забайкалья в городе Чита. Умер как на посту, отдав дань научным поискам, изысканиям. Михаил Моисеевич - участник Великой Отечественной войны. Как разносторонне одаренный человек, он изящно играл на рояле, знал шахматы, занимался фотографией, которая тогда была почти редкостью, исполнял песни разных времен и жанров, чему многие были свидетелями в один из сезонов отдыха на Байкале в пансионате «Ослик» (оздоровительный студенческий лагерь института культуры).

Одной из целей наших заметок, есть желание сохранить память о тех, кто ВСГИК считал своим вторым домом, кто знал и понимал студентов главный объект каждого учебного заведения в лучшем смысле понимания этого выражения. Ученый-историк, доцент Халзанов Кирилл Харлампович как профессионал был соавтором ряда крупных академических изданий, в 
том числе «Очерков истории культуры Бурятии» [5]. Его семья, родители в известные годы преследований были вынуждены бежать на Север, скрываться от репрессий и долго жить в условиях страха. Кирилл тогда был малолетним ребенком. Дело это было массовым и сегодня оно уже вышло из поля общественного зрения и остаётся уделом истории. Халзанов интересно рассказывал и нередко вводил своими юморными повествованиями в заблуждение слушателей, как, например, своей байкой о том, что он, будучи в Москве охотился из форточки на лося в одном из столичных парков. Рассказ его был так правдоподобен, что многими, в том числе и автором этих строк, воспринимался наяву. Почти сродни Мюнхгаузену. Как историк и любитель, занимался коллекционированием разных редкостей и этот собранный материал был представлен обширной коллекцией денежных знаков разных эпох, стран и народов, использовал на занятиях со студентами. Кирилл Харлампович был человеком бесхитростным, открытым, несмотря на пережитое. О таких людях сохраняется светлая память и теплые воспоминания.

Завершая свои воспоминания о коллегах-историках, хотелось бы вспомнить и имя Лабыгина Михаила Ильича - проректора вуза по заочному обучению, историка и члена нашей кафедры. Немногословный, тактичный и рассудительный, степенный в общении - таким он сохранился в памяти и в глазах тех, кто шел с ним рядом по жизни.

Скажем еще об одном из тех, кого сегодня нет с нами. Это Рубцов Юрий Иванович - историк и педагог, как говорится, от Бога. Он специализировался на зарубежной исторической проблематике и был поклонником поэтического творчества русских поэтов-классиков, имел слабость к собственному сочинительству и все это умело применял в работе со студентами.

Как видим, каждый из названных нами уважаемых историков имел ту или иную оригинальность, жизненную склонность, разнообразие и нес это в студенческую аудиторию, посвящая молодежь в свое «хобби», которое может быть более всего и остается в памяти благодарных слушателей, вводя их не только в академический предмет, но и в жизнь во всем ее многообразии.

К поколению «старичков» отнесем и еще одного из старожилов кафедры - человека заслуженного во многом и работавшего до самых последних ныне текущих дней - это Бадма Шаркуевич Доржиев. С ним мы знакомы с середины 1960-х годов, когда автор этих строк, начинал свою педагогическую работу в далеком городе Закаменске, что лежит на границе с Монголией. Бадма Шаркуевич возглавлял тогда Закаменский районный отдел народного образования, а автор был директором средней школы №1 г. Закаменска. А школа-то была - ой, ой! - пятых и шестых классов в ней доходило до буквы «И». И вот мы снова встретились в стенах ВСГАКИ, и причем, мой приход в институт был шагом, к которому меня подтолкнула рекомендация моего старого товарища по Закаменску, городу, вольфрам и молибден которого послужил победе в Великой Отечественной войне.

Справедливо сказать, не по годам, а по заслугам и делам, что не один год вместе с названными ветеранами трудились на кафедре истории. Санжиева Елена Гармажаповна, спокойный, разумный и знающий свое дело ис- 
торик, которая продолжает свою педагогическую деятельность в вузе и сегодня.

Время не стоит на месте, все в этом продуманном мире течет, изменяется, как говорили еще древние, подобно Гераклиту Темному - греческому философу. Так и в нашей обыденной жизни на смену одному поколению историков шло уже другое, не менее достойное. Заняли свое место на кафедре Владимир Лукич Кургузов, Леонид Владимирович Курас, Александр Иванович Шаповалов, Борис Ванданович Базаров - все они стали докторами исторических наук. В таком же звании на кафедре трудилась и трудится Ирина Батуевна Батуева. Большая часть из них на сегодня оставила ВСГИК, перешли в другие ведомства или уехали за пределы Сибири, как А.И. Шаповалов, которого можно считать одним из достойных ученых и педагогов. Это поколение тоже уже вступило в пенсионный возраст.

Мы здесь не составляем историю кафедры, но помнится, что на рубеже 1990-х годов кафедра как-то наполнилась многими молодыми лицами, которых и поименно-то вспомнить трудно, да просто невозможно. Не то это были аспиранты, не то штатные сотрудники. Лучше об этом мог бы рассказать Л.В. Курас, который тогда возглавлял кафедру. Но по всему было видно и невооруженным взглядом, что кафедра теряла свой стиль, которым она обладала много лет: сплоченность, научный потенциал, влияние на совокупную жизнь и деятельность вуза. Дело прошедшее, и не станем его больше тревожить, опять же исходя из вечной истины - все течет и меняется, не стоит на месте...

Под стать старшему поколению, отдавали свое мастерство, талант и призвание поклонники Клио (богини истории) и последующие педагогиисторики кафедры: Базаров Олег Дашиевич, Кузнецов Виктор Васильевич, Мункуева Надежда Мироновна, Бабаков Виктор Валерьевич, Голосовская Татьяна Владимировна, Цыремпилова Ирина Семеновна, Игумнов Евгений Владимирович, Банзаракцаева Елена Васильевна, Хлыстов Евгений Афанасьевич, Софонов Виталий Семенович, Бахрунова Елена Васильевна. Просим прощения, если кого-то пропустили без умысла. Никогда не забудется имя лаборантки Розы Васильевны Бараевой, которая в своем деле была как образец, ведь лаборант - это почти распорядитель жизни кафедры. Под стать были и лаборантки Минеева Ольга Петровна, Симухина Татьяна Васильевна.

Относительно преподавания истории как предмета, особо отметим, что в институте культуры, как и во многих других вузах, история относится к числу общеобразовательных дисциплин. Отсюда следует, что студент может смотреть на историю как второстепенный и необязательный предмет. А в тоже время помнится, что история непременно стояла в расписании на вступительных экзаменах в институт культуры, в состав экзаменационной комиссии входило несколько человек. Это как бы налагает особую дополнительную ответственность ведущего преподавателя за уровень своего предмета, чтобы возникали какие-то претензии со стороны студентов в целом по кафедре. 
Из своей практики вспоминаю, такой красноречивый факт: однажды по курсу «Истории России» мне пришлось студентам хореографического отделения прочитать наизусть строфы из «Евгения Онегина» А.С. Пушкина, где он в первой главе восторженно говорит о знаменитой русской танцовщице его времени Истоминой:

«Стоит Истомина; она,

Одной ногой касаясь пола,

Другою медленно кружит,

И вдруг прыжок, и вдруг летит,

Летит, как пух от уст Эола;

То стан совьет, то разовьет,

И быстрой ножкой ножку бьет».

Так мои слушатели готовы были носить на руках.

Так складывалась моя преподавательская работа, что больше приходилось общаться со студентами, как говорят в институте культуры, творческих кафедр, как хореографии, хоровиками, музыкантами, театралами и меньше с библиотекарями. Поэтому больше и ближе знал преподавателей этих дисциплин. Разве можно забыть почти рыцаря по виду и поступкам, речи и идеалам, заведующего кафедрой хореографии Леоненко Александра Ивановича и его сподвижника Палилея, да и других. В памяти сохранились и всплывают образы колоритных и заслуженных деятелей театральной кафедры Вампилова Буды Николаевича, Логачёва Николая Ефремовича, Найдаковой Валентины Цыреновны, Тришина Валерия Александровича и других. Честное слово, о каждом из них можно написать книгу, подобно серии «Жизнь замечательных людей». Заведующий кафедрой хорового дирижирования Белокрыс Михаил Алексеевич, человек разносторонних научных интересов, библиофил. Музыканты Аштаев Анатолий Иванович, Китов Виктор Васильевич, Огнев Олег Владимирович, Мусихин Владислав Федорович, Ваулин Александр, Михайлов Виктор, балалаечник Рогов, Прибылов Александр Александрович; культурологи, фотомастера Петров Василий Иванович, Манзырев Валерий, Чистяков Григорий Григорьевич, Крашневский, Герасимова О.А., Ильина Л.Н., Добрынин С.А., Рябушев В.Н., Хосомоев Н.Д., Родина Г.Н., Шалыгин Г.Ф., Сутягин А.М., Шепелева И.Д., Рещиков Н.И. и другие.

Много лет и даже не одно десятилетие костяк преподавателей библиотечного факультета, по крайней мере в мою бытность и на памяти, составляли инициативные и замечательные профессионалы своего дела, блиставшие не только на институтском поприще, но и в городе, республике и России ученые и энтузиасты - Баранов О.А., Езова С.А., Шулунова Л.В., Олзоева Г.К., Ажеева Р.Б., Модогоева Р.А., Ангапова З.Д., Баранова Э.Н., Авраева Ю.Б. Они прошли все степени педагогического роста, некоторые вышли из числа студентов нашего вуза.

ВСГИК всегда жил многообразной жизнью. Из его стен вышли художественные коллективы «Сибирский сувенир», под руководством выдающегося музыканта и дирижера Виктора Китова. 
Помнится ноябрь 1989 г., сцена аудитории 202, когда первый шаг сделал один из самых известных не только в Бурятии, но и в России, ансамблей «Забава». Его создание стало заслугой студента ВСГИК и Ленинградского института культуры, ныне видного музыкального деятеля Осипова Николая Борисовича.

В первом составе его были студенты нашего вуза - Бородина Татьяна, Гордейчук Сергей (единственный, кто и сегодня выступает в составе коллектива), Стефанов Сергей, Потапов Вячеслав, Нелюбина Татьяна, Малицкая Татьяна, Чучман Оксана, Козырь Юрий, Лоскутников Сергей. Интересно, что имя «Забава» молодежному студенческому коллективу русского фольклора дал не кто иной, как нынешний проректор института Столбовский Виктор Геннадьевич, ставший режиссёром коллектива. Об творчестве ансамбля «Забава» автору этих строк приходилось говорить со страниц республиканских газет. Ректор института С.И. Никифоров назвал «Забаву» одной из визитных карточек института культуры.

Работа в вузе - это, прежде всего, работа со студентами и для студентов. Как правило, к питомцам института я относился с высоким чувством ответственности и доброжелательностью, требовательностью и уважительно. Может быть, правда, и задним числом в чем-то себя и винишь, упрекаешь, но еще и до сих пор некоторые из выпускников, имя которых уже не помнишь, приветливо здороваются с тобой, - что и есть знак благодарности и доброй памяти.

Приходилось немало заниматься научным руководством докладами студентов, с которыми они ежегодно выступали на общевузовских конференциях. По подсчетам, сделанным по издававшимся программам, за все годы работы пришлось опекать почти сотню таких докладчиков, многие были монгольскими студентами. Ольга Красина работала над докладом «Славные сыны народа» в 1977 г. и прошла все инстанции отбора, в том числе и межвузовского и была рекомендована для участия в работе VI «Всесоюзной конференции по общественным наукам», где выступила успешно и достойно. Я, как научный руководитель, сопровождал свою подопечную в поездке в Москву на финальный этап конференции. Доклад был посвящен революционерам-железнодорожникам г. Верхнеудинска 1905 г., что вполне соответствовало времени и идеологии.

Немалое место в моей жизни занимали шахматы, которыми и ныне при возможности не пренебрегаю. А начало этому издалека, с родной Байкало-Кудары. Шахматы посильны всем возрастам и не знают служебной субординации. Эта «болезнь», говоря полушутя, неизлечима и было бы очень здорово, если бы ей было заражено как можно больше любителей. Не случайно в шахматном мире есть такая поговорка на латинском языке «gens uma sumus», что в переводе означает «мы одна семья» (девиз ФИДЕ). Сказать, что шахматы во ВСГИКе в мои времена были весьма популярны, их поклонниками были и первый проректор Бартенев Герман Федорович, и музыканты Тихонов Евгений Викторович, Зарецкий Александр, преподаватель кафедры «Кино-фото» Ханин, сегодня уж подзабыл имена некоторых. Каждый из них имел как бы свой почерк, линию поведения в игре на черно- 
белой доске. Спокойный Бартенев, взрывной и непоседливый Тихонов. Он, кстати, как музыкант тесно сотрудничал с одним из замечательных бурятских вокалистов народным артистом СССР Дугаржапом Дашиевым. Шахматы как игра и форма культуры, не обходились вниманием свыше и в 1976 г. Министерство культуры санкционировало проведение шахматного турнира среди вузов культуры. Он проходил в г. Петрозаводске, столице Карельской АССР. И мне выпала честь представлять ВСГИК на этих соревнованиях, высокого места я не занял, но выполнил норму первого любительского разряда.

Каждый, кто говорит или вспоминает о ВСГИКе, его людях, истории не может обойти тему почти легендарного лагеря «ОСЛИК», что находится на берегу нашего замечательного моря-озера Байкал. Это поселок с редким названием Энхалук, севернее устья реки Селенги, главного притока Байкала. Это очень благодатное по своим природным особенностям место, побережье, и выбор этого места для студенческого лагеря было непростым делом, сопряжённым с преодолением немалых административных трудностей. Эту проблему успешно разрешил наш ректор С.И. Никифоров, о чем он повествует в своих воспоминаниях. А я вспоминаю детство в Байкало-Кударе, слова матери, которая рыбачила на этих берегах еще в 1920-е годы, когда они добывали омуля - «стояли на сетях», неводили, что означало стоять босыми ногами в ледяной байкальской воде. Энхалук моя мать называла красивейшим берегом Байкала.

«ОСЛИК» имеет длинную историю и до Энхалука размещался как временный летний лагерь отдыха в районе озера Котокель, вблизи неспокойного и «боевого» Баргузинского тракта, более чем в 200 км. от г. УланУдэ. Пребывание там было и беспокойным, и опасным, так как по тракту люд ехал разный, а в лагере-то девчонки-студентки... И судьба привела «ОСЛИК» в Энхалук. Дело по устройству лагеря было возложено на кафедру физического воспитания, которая тогда крепко стояла на ногах, а возглавлял ее разумный и деятельный человек Семен Николаевич Кириков, известный лыжник Бурятии, уроженец Прибайкалья. Под стать были и его коллеги - преподаватели физического воспитания Коняев Николай Петрович, Двоеглазов Владимир Васильевич, Сахаровский Валерий Павлович, деятельная лаборантка Осколкова Татьяна Федоровна. И начали они и отдыхающие забивать первые гвоздики в штакетник ограды лагеря... Приходилось это не только видеть, но и активно участвовать...

Летние сезоны второй половины 1970-х - начала 1980-х гг. помнятся товарищеским, дружеским складом общения. Отдыхающих было много, но почти «штатно» на Байкал ездили семья М.А. Белокрыса, А. Аштаева, Л. Свитина, Ю.А. Хараева, В.К. Назарова - почти как «визитная карточка» ВСГИКА, З.К. Хуригановой, скрашивал своим незабываемым юмором и добродушием общество отдыхающих О.Н. Бурлаков. Не буду больше поименно называть друзей по «ОСЛИКу» по сбивчивости памяти и давности времени... Замечательное было время и его люди! Год назад зашел почти случайно в ограду «ОСЛИКа» и вижу современный железный забор, проход на берег Байкала через замковую калитку, строгие лица новых «команди- 
ров». Аттестовать эти новшества с позиции уже далекого времени не беремся - «каждому времени свои песни», как говорится в русской пословице.

Среди знаковых событий прошлого не стираются из памяти участие института культуры, всего коллектива в организации и проведении значимых праздников страны - 1 Мая - День Международной солидарности трудящихся и 7 Ноября - День Октябрьской революции 1917 г. Сегодня эти праздники тихо и без шума ушли в прошлое. Это были чисто политические праздники, о содержании и оценке их мы здесь воздержимся, но вспомним, как шла подготовка к ним и участие.

Как правило, заранее, примерно за месяц, создавались по инициативе партийной организации и поддержке ректората комиссии, на плечах которой лежала ответственность проведения всех подготовительных мероприятий, таких как подготовка транспарантов, лозунгов, портретов видных политических деятелей страны прошлого и текущего времени, внешнее оформление здания вуза, проведение торжественных собраний. В дни праздников на центральной площади Советов г. Улан-У дэ проводились демонстрации, куда направлялись своей колонной все преподаватели и сотрудники института. За день-два до этого в институте приводились собрания, на которых выступали докладчики, вручались грамоты отличившимся членам коллектива. Чаепитий по этому поводу что-то не припоминаю. Сегодня поднявшееся поколение 20-30-летних всего этого не видели, а некоторые кто постарше едва ли помнят.

В ряду со сказанным, в институте систематически проводились партийные собрания коммунистов, но посетить их мог каждый, хотя с трудом помнится, чтобы это было так. На них обсуждались разные вопросы, конечно, вытекавшие в основном из жизни самого вуза. Автору уже накануне роспуска КПСС приходилось быть секретарем партийной организации ВСГИКа, но до окончания срока по собственной инициативе я оставил эту общественную обязанность, которую возложили на Бориса Базарова - нынешнего директора ИМБТ СО РАН, широко известного в Бурятии. Такая рокировка состоялась накануне запрета КПСС и исключения из Конституции страны статьи №6 «О руководящей роли партии в СССР». Все это были эпохальные, почти трагические события, о которых мы говорили выше.

Наши заметки составляются как раз в дни празднования 75-летия со дня Победы. Вспомнилось, что перед уходом из института в 2007 г., в канун этого праздника, пытаясь узнать мнения студентов об это празднике, попросил их сказать, что они думают. Хотелось, чтобы молодые люди высказались, пусть и письменно, но искренне и потому я попросил их не указывать имена, фамилии, но одновременно уточнил, что мне интересно их мнения. Это были студенты, помнится, театрального отделения, двадцать человек, те есть учебная группа. И сегодня эти свидетельства, которые хранятся и ныне, возьми любое из них, и в каждом, молодые люди с высокой степенью благодарности говорят о победителях и стране, выражают свои соболезнования жертвам войны. Тема, вопрос для суждений моих студентов был поставлен в самой простой форме: «Что я думаю о Дне Победы». Для иллюстрации приведем несколько записей подлинных свидетельств молодых людей: 
I. «На мой взгляд День победы - это самый замечательный день. День, который весь мир ждал столько лет, противостоял фашистским захватчикам. На сегодняшний день осталось очень мало людей, кто пережил эти страшные годы войны. Мне стыдно за то, что их чтят и вспоминают лишь один день в году, что им не дали достойно жить после войны. Именно они, защитники, которые не дали обладать тиранам миром. Они - самые достойные жители земли. Пройдут года, века, тысячелетия, но память о них будет жить всегда».

II. «Для меня этот день всегда был праздником. Помню, как еще совсем маленькой ходила с дедушкой, ветераном войны, на праздничные парады. Помню то радостное и светлое чувство, которое меня переполняло. Оно и сейчас осталось во мне. Единственно, что меня разочаровывает, то, что сейчас власти превратили этот праздник во многих городах нашей Родины в некий рекламный трюк, то есть повод для рекламы политических партий, магазинов. Мне кажется, что в этот светлый день не должна быть примешена политика. Для меня День Победы - это наша память, великая память нашего народа».

III. «День Победы - это праздник всего народа. 9 мая - это великий день. День, наполненный слезами, скорбью, смехом, радостью. В нем все неоднозначно и все же праздник. О если б можно было докричаться до тех, кто погиб, спасая Родину и сказать им огромное спасибо. Мы, люди нового поколения, времени, многим обязаны - жизнью обязаны. Спасибо Вам, спасибо за этот день!».

Эти три свидетельства взяты из общей стопки почти наугад, так как были покороче других, но смысл почти тот же. Студентам заранее не говорилось, что им придется писать о Дне Победы, и их суждения можно рассматривать как устоявшееся, постоянное мнение о победе. Как видно, высказаны зрелые мысли, достойные похвалы, и мы их рассматриваем как суждения поколения современной российской молодежи. Мы видим, что молодые люди критично оценивают политическую конъюнктуру властей на некоторые стороны праздника и дают им свою оценку той парадной и шумной кампании, которую мы наблюдаем и по сей день. А ведь эти записи сделаны более 10 лет назад, молодые люди видят себя сопричастными Дню Победы и это делает им честь!

В контексте похвальных слов о достойном уровне мировоззрения студентов, их чувстве долга гражданина, напомним современному читателю, что в условиях пика перестройки, примерно в конце 1980-х годов, времени демократизации был предпринят эксперимент по введению наиболее активных студентов в состав Ученого Совета ВСГАКИ. Нам представляется, что этот шаг был верным и может быть достоин повторения.

За время работы во ВСГАКИ в моем послужном списке было заведование кафедрой в непростые 1993-1998 гг., когда происходила переориентация блока предметов исторического цикла с учетом изменившейся в России политической обстановки. Почти в эти же годы принимал участие в выполнении хоздоговорных тем и на этой работе был занят несколько лет, в частности, в качестве руководителя по социально-культурному развитию колхо- 
за «Сибиряк» Тункинского района. До сих пор сохраняю теплые воспоминания об этой работе, в том числе о замечательном и деятельном сослуживце Гунзынове Владимире Цыреновиче, а также о педагоге хоровой кафедры Назаровой Венере Хушиновне, хореографе Слодовой Любови и других.

И вот летом 2008 года я оставляю институт и становлюсь «свободным» гражданином. Прошло уже ровно 12 лет с того памятного для меня шага, но я не сидел на месте и не лежал на диване. Еще до оставления института я на основе, архивных материалов написал и издал несколько трудов о своей Малой родине - истории села Байкало-Кудара, Кабанского района Республики Бурятия: в 2002 году иллюстрированную книгу-альбом «Байкало-Кудара: 300 лет истории» - моё и до сего дня любимое «детище» [6]. В соавторстве с выпускницей Кударинской средней школы Любовью Алексеевной Зайцевой - доктором исторических наук мы написали книгу «Байкало-Кударинская школа. 150 лет» [7]. Несколько позже, в 2007 году составил и издал еще одну книгу «Трудные судьбы раскулаченных крестьян БайкалоКудары» [8]. Истории своей Малой родины я посвятил ряд статей, опубликованных в разных сборниках, выходивших в Улан-Удэ. Одновременно, по возможности, сотрудничал с коллективом школы своего села, православным храмом Благовещенской церковью Байкало-Кудары, о которой сделал ряд публикаций, готовил тексты для рекламных баннеров. С учётом видно всех этих обстоятельств и как уроженцу местная администрация присвоила мне звание «Почетный гражданин МО СП Байкало-Кударинское» за №1. Принял это с пониманием.

Государственный архив Республики Бурятия стал в текущие годы базовым местом для написания других книг, посвященных истории православия в наших краях, за Байкалом. В 2012 г. мною в Иркутске была издана книга «Верхнеудинская Спасская церковь. 1696 - 1930 годы» [9]. На это праведное дело меня подвигло то, что этот храм может по праву считаться первым в нашем городе, (тогда, в конце XVII века, Удинске - Верхнеудинске, с 1934 г. - Улан-Удэ) и трагически закончил свою историю в мае 1936 года, когда был взорван местными правителями. Книгу можно рассматривать как памятник и храму, и сотням верующих, которые столетиями молились в его стенах не только за себя, но за нас, потомков. В книге названы имена прихожан Спасской церкви: мещан, посадских крестьян, чиновников, казаков, служилых людей, многих священно-церковнослужителей разного ранга, крестьян и других. Книге дали рецензии местный епископ Савватий и замечательный краевед города Голубев Евгений Александрович. Как я сам приступил к написанию этого труда, что меня подтолкнуло? На этот вопрос не могу ответить и сейчас, но больше всего, наверное, желание, как историка, сказать благодарственное слово о предках, которым мы многим обязаны.

На основе страниц моей книги и в память о Верхнеудинской Спасской церкви в 2014 году «Общество русской культуры» при въезде на Удинский мост с правой стороны воздвигло достойный Поклонный крест, ставшим началом улицы Соборной. Теперь каждый проезжающий в Октябрьский район города Улан-Удэ может лицезреть это сооружение, в установке которого мне посчастливилось участвовать. 
В 2013 году издал еще одну книгу под названием созвучным первой «Итацинская Спасская церковь XVIII века» [10]. Начало этого труда было необычным, я сотрудничал с организацией «Русский культурный центр» и один из его участников попросил написать что-то об этой церкви. Поначалу эту просьбу я не воспринял всерьез, а через некоторое время этот человек упал мне в ноги с этой же просьбой. Что оставалось делать? Так и родилась это достаточно объемная книга о гражданах Итанцинской долины.

Мое внимание к истории местного христианства имеет под собой не столько религиозный, сколько общественный и гражданский смысл - высказать благодарственное слово о предках и по возможности, назвать их поименно, так как они сохранились на страницах архивных дел и фондов. Хорошо известна истина, что без знания прошлого нет и будущего. Вот это и есть главный двигатель моих изысканий в данном направлении.

По возможности и по силам продолжаю и сегодня что-то делать, поступают просьбы и из районов сказать письменное слово о сакральных местах...

В завершении нашего повествования, скажем, что представляли огласке только то, чему были сами свидетелями или участники, занявшие свою нишу в институтской иерархии. ВСГИК прошел в своей истории несколько ступеней: первоначально был библиотечным институтом, после стал институтом культуры, вслед за этим перешел в статус академии. Но не помнится, что это возвеличивание было в коллективе воспринято с энтузиазмом. Время было такое, когда реклама в какой бы не было сфере, выходила на передний план. И вот мы снова институт культуры - это как-то твёрже и слышится, и правдивее.

Следовало хотя бы бегло сказать о главных фигурах вуза - ректорах. При мне их было три, и что интересное все «Ивановичи»: Сергей Иванович Никифоров, Гаврила Иванович Балханов и Раиса Ивановна Пшеничникова. Не беремся говорить об их достоинствах и недостатках. Я был более расположен к Сергею Ивановичу Никифорову - человеку сдержанному, интеллигентному, которого знал еще с первой половины 1960-х гг., когда он еще молодой, красивый читал студентам педагогического института исторические дисциплины. Меньше могу сказать о Гавриле Ивановиче Балханове, да и работал он только один срок. Ректорство Раисы Ивановны пришлось на непростые годы отечественной истории, когда надо было биться за жизнь института, отстаивать его существование в 1990 -е и последующие года. И тут боевой и напористый стиль руководства со стороны Раисы Ивановны как раз оказался к месту. И всем троим - большое спасибо за их труды и самоотверженность!

Сегодняшняя жизнь института во всем ее многообразии нам неизвестна, да это и не наше время, не наша забота. Но хотелось бы, чтобы вузом руководили люди такие же достойные, знавшие его жизнь не понаслышке, а изнутри. Не хотелось бы, чтобы вуз оказался в руках случайных людей, что в наше время не исключено. Одним из залогов на пути такого несчастья может быть коллективная зрелость преподавателей, для которых, надеемся и верим, судьба вуза есть и их судьба. 


\section{Примечания}

1. Батуев Б. Б. Мария Михайловна Сахьянова: страницы политической биографии / науч. ред. Л. В. Курас ; Вост.-Сиб. гос. ин-т культуры ; Обществ.-науч. центр "Сибирь". Улан-Удэ, 1992.

2. Бадмацыренов С. С. Труд - основа коммунистического воспитания учащихся. Улан-Удэ : Бурят. кн. изд-во, 1975. 136 с.

3. Шмулевич М. М. Троицко-Селенгинский. Улан-Удэ : Бурят. кн. изд-во, 1982. 64 с.

4. Шмулевич М. М. Очерки истории Западного Забайкалья. XVII середина XIX в. Новосибирск : Наука, Сиб. отд-ние, 1985. 286 с.

5. Очерки истории культуры Бурятии : в 2 т. / [общ. ред.: Д. Д. Лубсанов (гл. ред.), [и др.] ; АН СССР. Сиб. отд-ние. Бурят. филиал, Бурят. ин-т обществ. наук. Улан-Удэ : Бурят. кн. изд-во, 1972-1974.

6. Байкало-Кудара: 300 лет истории / [авт. проекта и текста Л. Г. Орлов ; фотохуд. С. М. Конечных]. Улан-Удэ, 2002. 30 с.

7. Зайцева Л. А., Орлов Л. Г. Байкало-Кударинская школа: 150 лет. Улан-Удэ : Изд-во БГСХА, 2002. 126 с.

8. Орлов Л. Г. Трудные судьбы раскулаченных крестьян БайкалоКудары. 1920-1930: история, документы, комментарии / Вост.-Сиб. гос. акад. культуры и искусств. Улан-Удэ : БНЦ СО РАН, 2007. 276 с.

9. Орлов Л. Г. Верхнеудинская Спасская церковь (1696-1930 годы): исторические сюжеты / Ком. по межнац. отношениям и развитию граждан. инициатив при Правительстве Респ. Бурятия, Окружное казачье о-во РБ "Верхнеудинское". Улан-Удэ ; Иркутск, 2012. 216 с.

10. Орлов Л. Г. Итанцинская Спасская церковь XVIII века : док. повествование. Улан-Удэ : БНЦ СО РАН, 2013. 406 с.

\section{References}

1. Batuev B. B. Marija Mikhajlovna Sakhjanova: stranicy politicheskoj biografii [Mariya Mikhailovna Sakhyanova: pages of political biography] / scient. editor L. V. Kuras] ; East Siberian state institute of culture ; Public scient. center "Siberia". Ulan-Ude, 1992. [In Russ.].

2. Badmatsyrenov S. S. Trud - osnova kommunisticheskogo vospitanija uchashchikhsja [Labour - the basis of the learners' communist education]. UlanUde, 1975. 136 p. [In Russ.].

3. Shmulevich M. M. Troicko-Selenginskij monastyr' [Troitsk Selenginsk monastery]. Ulan-Ude, 1982. 64 p. [In Russ.].

4. Shmulevich M. M. Ocherki istorii Zapadnogo Zabajkal'ja. XVII seredina XIX v. [Feature articles about the history of Western Zabaikalia]. Novosibirsk, 1985. 286 p. [In Russ.].

5. Ocherki istorii kul'tury Burjatii [Feature articles of the culture history of Buryatia] : in 2 vol.] / [edited by D. D. Lubsanov (chief ed.), [et al] ; AS SSSR. $\mathrm{Sib}$. branch of the Buryat depart, Buryat in-t of social sciences. Ulan-Ude, 19721974. [In Russ.]. 
6. Bajkalo-Kudara: 300 let istorii [Baikalo-Kudara: 300 years of history] / [the author of the project and text L. G. Orlov; photoartist S. M. Konechnykh]. Ulan-Ude, 2002. 30 p. [In Russ.].

7. Zaitseva L.A. , Orlov L.G. Bajkalo-Kudarinskaja shkola: 150 let [Baikalo-Kudara school]. Ulan-Ude, 2002. 126 p. [In Russ.].

8. Orlov L. G. Trudnyje sud'by raskulachennykh krest'jan BajkaloKudary. 1920-1930: istorija, dokumenty, kommentarii [Hard destinies of the dispossessed peasants of Baikal-Kudara. 1920-1930] / East-Sib. state academy of culture and arts. Ulan-Ude, 2007. 276 p. [In Russ.].

9. Orlov L. G. Verkhneudinskaja Spasskaja cerkov' (1696-1930 gody): istoricheskije sjuzhety [Verkhneudinsk Spasskaya church [1696-1930): historical stories] / The com. of intern. relations and development of civil initiatives at the Government of the Republic of Buryatia, District Cossacks' society of RB "Verkneudinskoye". Ulan-Ude, 2012. 216 p. [In Russ.].

10. Orlov L. G. Itancinskaja Spasskaja cerkov' XVIII veka : dok. povestvovanije [Itansta Spasskaya church of the XVIII century: doc. narration]. Ulan-Ude, 2013. 406 p. [In Russ.]. 
DOI 10.31443/2541-8874-2020-3-15-165-168

УДК 1-051(571.54)+378.6(571.54-25)

Дандарон М. Б.

Dandaron M. B.

ПРОФЕССОР Г. И. БАЛХАНОВ В НАУКЕ И ОБРАЗОВАНИИ

PROFESSOR G. I. BALKHANOV IN SCIENCE AND EDUCATION

Балханов Гавриил Иванович, доктор философских наук, профессор, член-корреспондент Сибирского отделения Академии наук высшей школы РФ, заслуженный деятель науки Республики Бурятия и Российской Федерации, заслуженный работник Высшей школы Российской Федерации, ректор ВСГИК с 1990 по 1995 гг., заведующий кафедрой социально-философских дисциплин 1998-2006 гг.

Gavriil Ivanovich Balkhanov, Doctor of Philosophy, professor, corresponding member of the Siberian branch of the Academy of Sciences of higher educational school of the Russian Federation, honored scientist of the Republic of Buryatia and the Russian Federation, honored worker of the Higher educational school of the Russian Federation, rector of ESSIC from 1990 to 1995, chief of the department of social and philosophical disciplines in 1998-2006.

Ключевые слова: Балханов Гавриил Иванович, доктор философских наук, профессор, краткая биография, научный путь, философская школа, ученики.

Keywords: Balkhanov Gavriil Ivanovich, Doctor of Philosophy, professor, short biography, scientific path, school of philosophy, students.

Балханов Гавриил Иванович, доктор философских наук, профессор, член-корреспондент Сибирского отделения Академии наук высшей школы РФ, заслуженный деятель науки Республики Бурятия и Российской Федерации, заслуженный работник Высшей школы Российской Федерации. Имеет свыше 60 публикаций, из них 5 монографий. Был научным руководителем свыше 10 кандидатов и докторов наук. Под его научным руководством аспиранты, докторанты защитили диссертации по философии, социологии, культурологии, политологии. Балханов Г.И. читал лекционные курсы по «Философии», «Политологии», «Истории и методологии науки», «Философии науки» для студентов, магистрантов, аспирантов и соискателей.

Балханов Гавриил Иванович родился 26 сентября 1934 г. в деревне Хоргелок Иркутской области, в многодетной семье крестьянина был старшим сыном. Отец его рано умер, он с детства начал помогать матери, работавшей в колхозе. Несмотря на то, что ему приходилось заботиться о семье, поднимать младших детей, он всегда хорошо учился и успешно прошел все этапы учебы, которые были доступны в то время. В 1941 г. пошел в начальную школу, после окончания которой, учился в Верхнеединской семилетке, затем поступил в Боханское педагогическое училище. После окончания училища, до призыва в армию, в течение одного года работал учителем русско- 
го языка и литературы в Орликской средней школе Бурятской АССР [2, с. $151]$.

В 1955 г. был призван в армию, прослужил 3 года. Затем поступил в Иркутский государственный университет. Во время учебы в университете начинает работу. Два года проработал учителем в родной Укырской школе. В системе народного образования работал учителем, завучем школы, директором школы, инспектором райОНО (отдел народного образования) и окрОНО.

После переезда в Усть-Орду был одним из организаторов окружного радио, которое вещало на русском и бурятском языках. Работал в качестве корреспондента-журналиста, главного редактора, был автором радиопрограмм и новых проектов вещания на русском и бурятском языках, в результате был принят в Союз журналистов СССР. Проблемы бурятско-русского двуязычия, с которыми приходилось сталкиваться при журналистской работе, зародили интерес к научно-исследовательской работе.

В конце 1960-ых годов в Бурятии было организовано научноисследовательское академическое учреждение - Бурятский филиал Сибирского отделения Российской академии наук - БФ СО РАН СССР. В институте общественных наук (БИОН) сформировался сектор социологии для конкретно социологических исследований СМИ (средств массовой информации). Там закончил аспирантуру, подготовил кандидатскую диссертацию по философии, затем защитил докторскую диссертацию в диссертационном совете по философии СО РАН в Новосибирске. После присвоения ученой степени доктора философских наук, прошел по конкурсу на заведующего кафедрой социально-философских дисциплин Восточно-Сибирского государственного института культуры.

В 1990 г. на первых демократических выборах был избран ректором института. Конец 80-х - начало 90-х гг. ХХ века было временем радикальных перемен в жизни страны. Вузы в те годы оказались в трудном положении - резко сократилось финансирование, было прекращено обеспечение их материалами, оборудованием, техникой. Главным лозунгом тех лет было "выжить" и сохранить научные и педагогические кадры. В сложное переходное время институт приобрел известность в сфере подготовки кадров в области культуры и искусства. Научный авторитет ректора открыл дорогу институту в сферу профессионального искусства и научноисследовательских изысканий. Когда в академии была открыта аспирантура и диссертационный Совет по защите докторских и кандидатских диссертаций по культурологии, Гавриил Иванович был заместителем председателя данного Совета. Также он входил в диссертационный Совет Российской Федерации - Д. 212.022.01 по защите докторских и кандидатских диссертаций по философии, социологии, политологии Бурятского госуниверситета. Являлся членом диссертационных Советов БГУ, ВСГАКИ, а также зам. председателя диссертационного Совета по культурологии ВСГАКИ.

С 1998 по 2006 годы Гавриил Иванович возглавлял кафедру сначала социально-философских дисциплин, а затем философии. Под руководством профессора Г.И. Балханова осуществлены научные исследования по поли- 
тическим проблемам, по проблемам религиозного сознания, его влияния на духовно-нравственный облик личности.

Политологическая проблематика получила свое научное осмысление в его работах, а также в диссертациях, подготовленных под руководством профессора Г.И. Балханова. В 1985 г. он защитил докторскую диссертацию «Политическая пропаганда в системе идеологической деятельности» на соискание ученой степени доктора философских наук. В 2005 г. его аспирант Д.Ц. Будаева выполнила диссертационную работу «Электоральное поведение населения в условиях реформирования российского общества (на материалах Республики Бурятия)». Обращение к данной проблеме было продиктовано тем, что, хотя система демократических выборов была введена в российскую действительность, однако не до конца решена задача широкого вовлечения населения в процесс формирования выборных органов власти. Эйфория первых альтернативных выборов, когда на них являлось до 90\% избирателей, постепенно замещалась разочарованием, аполитичностью, неверием в возможность образования демократических институтов власти. Перед исследователями встала задача проведения социально-философского анализа причин абсентизма и негативизма, и определения электоральных предпочтений регионального электората [1, с. 172]. Исследование проблемы электорального поведения населения было продолжено диссертантом В.Э. Матхановым в диссертации «Выборы как политико-правовой институт избирательного поведения населения» под руководством Г.И. Балханова. В ней дан философский анализ избирательного поведения как составной части политической культуры, выявлены основные тенденции электорального поведения и методы их прогноза и планирования, намечены пути реализации стратегического плана выборной компании. Эти работы представляют не только научный интерес, но и практическую значимость [1, с. 173].

Профессором Г.И. Балхановым разрабатывались философские аспекты традиционных и национальных форм феномена культуры. Под его руководством защищена кандидатская диссертация на соискание ученой степени кандидата культурологии Ц.Е. Ренчиновой «Сагаалган в духовнонравственной культуре бурят», издана монография в соавторстве. Философские аспекты исследования были продолжены в работах по анализу религиозных форм сознания. Под его руководством написана и защищена кандидатская диссертация Э.А. Николаева «Христианство как фактор формирования духовно-нравственных основ личности», где продолжается исследование духовно-нравственного развития и становления личности под влиянием религии - христианства. Профессор Г.И. Балханов является научным руководителем диссертационного исследования М.Б. Дандарон «Социальное конструирование религиозного сознания» на соискание ученой степени доктора философских наук. Анализ религиозного сознания, его происхождение и становление концептуально основан на комплексе современных философских теорий: исследование измененных состояний сознания ИСС и их роль в возникновении религиозных верований и представлений (С. Гроф, Е. Торчинов, А. Миндел и др.), теория социального конструирования реальности Бергера и Лукмана и др. 
В целом заданный профессором Гавриилом Ивановичем Балхановым вектор проблем философских научных исследований, их тематика, способ постановки и решение, методологические подходы являются актуальными и современными и это направление имеет большой теоретикометодологический потенциал, а также возможности практического применения в дальнейших научных изысканиях.

О нем:

Балханов Гавриил Иванович // Преподаватели Восточно-Сибирской государственной академии культуры и искусств (1995 - май 2005 гг.) : справочник / Восточно-Сибирская государственная академия культуры и искусств" ; сост.: Т. В. Бурлакова, И. А. Поняева ; науч. ред. Р. И. Пшеничникова]. - Улан-Удэ, 2005. - С. 23-24.

Балханов Гавриил Иванович // Ученые-исследователи Бурятского института общественных наук СО РАН : (к 75-летию ин-та) : библиогр. справ. / Бурят. науч. центр СО РАН, Ин-т обществ. наук ; редкол.: В. Ц. Найдаков [и др.] ; сост. Л. Д. Бадмаева [и др.]. - Улан-Удэ, 1997. - С. 33.

Осинский И. И. Состав диссертационного совета. Балханов Гавриил Иванович // В научном поиске (взгляд сквозь призму диссовета) / И. И. Осинский ; М-во образования и науки Рос. Федерации, Бурят. гос. ун-т. Улан-Удэ, 2013. - С. 39.

Дандарон М. Б. Балханов Гавриил Иванович // Бурятия : календарь знаменательных и памятных дат на 2019 год : справ.-библиогр. изд. / Нац. бка Респ. Бурятия, Центр библиогр. и краеведения ; сост. З. Б. Жигмитова [и др.]. - Улан-Удэ, 2018. - С. 151-153.

\section{Примечания}

1. Осинский И. И. В научном поиске (взгляд сквозь призму диссовета) / Бурят. гос. ун-т. Улан-Удэ, 2013. 264 с.

2. Дандарон М. Б. Балханов Гавриил Иванович // Бурятия : календарь знаменательных и памятных дат на 2019 год : справ.-библиогр. изд. / Нац. бка Респ. Бурятия, Центр библиогр. и краеведения ; сост. З. Б. Жигмитова [и др.]. Улан-Удэ, 2018. С. 151-153.

\section{References}

1. Osinskiy I. I. V nauchnom poiske (vzgljad skvoz prizmu dissoveta) [In the scientific search (a glimpse through the prizm of the dissertation council] / Buryat. gos. un-t [The Buryat state university]. Ulan-Ude, 2013. 264 p. [In Russ.].

2. Dandaron M. B. Balkhanov Gavriil Ivanovich [Balkhanov Gavriil Ivanovich] // Burjatija : kalendar' znamenatel'nykh i pamjatnykh dat na 2019 god : sprav.-bibliogr. izd. [Buryatia : calendar of significant and memorable dates in 2019 : reference-bibliogr. edition / National library of the Republic of Buryatia, Centre of bibliogr. and local history ; comp. by Z. B. Zhigmitova [et al]. UlanUde, 2018. Pp. 151-153. [In Russ.]. 


\section{СВЕДЕНИЯ ОБ АВТОРАХ}

1. Амгаланова Мария Викторовна, кандидат культурологии, доцент кафедры культурологии и искусствоведения ФГБОУ ВО ВСГИК (г. Улан-Удэ).

2. Арбатская Ольга Александровна, кандидат педагогических наук, доцент кафедры библиотечно-информационных ресурсов ФГБОУ ВО ВСГИК (г. Улан-Удэ).

3. Аюшеева Марина Васильевна, кандидат исторических наук, старший научный сотрудник Института монголоведения, буддологии и тибетологии СО РАН (г. Улан-Удэ).

4. Бадмаев Алдар Геннадьевич, кандидат географических наук, научный сотрудник ФГБУН Байкальский институт природопользования СО РАН (г. Улан-Удэ).

5. Базарова Оюна Владимировна, кандидат экономических наук, доцент кафедры международного права и международных отношений ФГБОУ ВО ВСГУТУ (г. Улан-Удэ).

6. Бояк Татьяна Николаевна, доктор социологических наук, профессор кафедры социально-культурной деятельности ФГБОУ ВО ВСГИК (г. Улан-Удэ).

7. Волобуева Наталия Владимировна, старший преподаватель кафедры инструментального исполнительства и музыкального искусства эстрады ФГБОУ ВО ВСГИК (г. Улан-Удэ).

8. Воронцова Любовь Сергеевна, доцент кафедры дизайна ФГБОУ ВО ВСГИК (г. Улан-Удэ).

9. Гомбожапов Александр Дмитриевич, кандидат исторических наук, старший преподаватель кафедры международного права и международных отношений ФГБОУ ВО ВСГУТУ (г. Улан-Удэ).

10. Дандарон Мэдэгма Бидияевна, доктор философских наук, профессор кафедры истории и философии ФГБОУ ВО ВСГИК (г. Улан-Удэ).

11. Дементьева Виктория Викторовна, кандидат культурологии, доцент кафедры культурологии и искусствоведения ФГБОУ ВО ВСГИК (г. Улан-Удэ).

12. Дикий Ярослав Витальевич, лаборант-исследователь Института монголоведения, буддологии и тибетологии СО РАН (г. Улан-Удэ).

13. Ершова Оксана Сергеевна, специалист центра заочного и дополнительного образования ФГБОУ ВО ВСГИК (г. Улан-Удэ).

14. Кириллова Наталия Константиновна, кандидат технических наук доцент кафедры реставрации и экспертизы объектов культуры ФГБОУ ВО СПбГИК (г. Санкт-Петербург).

15. Маншеева Соёлма Цыдыповна, доцент кафедры этнологии и народной художественной культуры ФГБОУ ВО ВСГИК (г. Улан-Удэ).

16. Назаров Виктор Кузьмич, кандидат педагогических наук, доцент кафедры культурологии и искусствоведения ФГБОУ ВО ВСГИК (г. Улан-Удэ). 
17. Немчинова Тамара Александровна, кандидат исторических наук, доцент, начальник учебно-методического управления ФГБОУ ВО ВСГИК (г. Улан-Удэ).

18. Орлов Леонид Георгиевич, кандидат исторических наук, доцент, почетный профессор ФГБОУ ВО ВСГИК (г. Улан-Удэ).

19. Рещиков Николай Иванович, доцент кафедры хорового дирижирования, звукорежиссуры и вокального искусства ФГБОУ ВО ВСГИК (г. Улан-Удэ).

20. Солнцева Галина Николаевна, доцент, заведующий кафедрой дизайна ФГБОУ ВО ВСГИК (г. Улан-Удэ).

21. Тимошенкова Анастасия Максимовна, магистрант 1 курса направления подготовки «Реставрация произведений декоративноприкладного искусства» ФГБОУ ВО СПбГИК (г. Санкт-Петербург).

22. Хобракова Людмила Матвеевна, кандидат филологических наук, доцент, заведующий кафедрой иностранных языков и общей лингвистики ФГБОУ ВО ВСГИК (г. Улан-Удэ).

23. Цыремпилова Ирина Семеновна, доктор исторических наук, доцент, проректор по научной работе ФГБОУ ВО ВСГИК (г. Улан-Удэ)

24. Шойбонова Саяна Викторовна, кандидат филологических наук, доцент кафедры литературы и языкознания ФГБОУ ВО ВСГИК (г. Улан-Удэ). 


\section{INFORMATION ABOUT THE AUTHORS}

1. Amgalanova Mariya Viktorovna, Ph.D. in Culturology, associate professor of the department of Culturology and Art History, FSBEI HE «East Siberian state institute of culture» (Ulan-Ude city).

2. Arbatkaya Olga Alexandrovna, Ph.D. in Pedagogy, associate professor of the department of Library Information Resources, FSBEI HE «East Siberian state institute of culture» (Ulan-Ude city).

3. Ayusheeva Marina Vasilyevna, Ph.D. in History, senior researcher, Institute for Mongolian, Buddhist and Tibetan Studies, SB RAS (Ulan-Ude city).

4. Badmayev Aldar Gennadyevich, Ph.D. in Geography, researcher, FBIS «Baikal Nature Management Institute», SB RAS (Ulan-Ude city).

5. Bazarova Oyuna Vladimirovna, Ph.D. in Economics, associate professor of the department of International Law and International Relations, FSBEI HE «East Siberian state university of technology and management» (Ulan-Ude city).

6. Boyak Tatyana Nikolaevna, D.Sc. in Sociology, professor of the department of Socio-Cultural Activity, FSBEI HE «East Siberian state institute of culture» (Ulan-Ude city).

7. Volobueva Natatiya Vladimirovna, senior teacher of the department of Instrumental Performing and Variety Musical Art, FSBEI HE «East Siberian state institute of culture» (Ulan-Ude city).

8. Vorontsova Lubov Sergeevna, associate professor of the department of Design, FSBEI HE «East Siberian state institute of culture» (Ulan-Ude city).

9. Gombozhapov Alexander Dmitrievich, Ph.D. in History, senior teacher of the department of International Law and International Relations, FSBEI HE «East Siberian state university of technology and management (Ulan-Ude city).

10. Dandaron Medegma Bidiyaevna, Sc.D. in Philosophy, professor of the department of History and Philosophy, FSBEI HE «East Siberian state institute of culture» (Ulan-Ude city).

11. Dementyeva Viktoria Viktorovna, Ph.D. in Culturology, associate professor of the department of Culturology and Art History, FSBEI HE «East Siberian state institute of culture» (Ulan-Ude city).

12. Dikiy Yaroslav Vitalyevich, laboratory researcher, Institute for Mongolian, Buddhist and Tibetan Studies, SB RAS (Ulan-Ude city).

13. Yershova Oksana Sergeevna, specialist of the center of extramural and additional education, FSBEI HE «East Siberian state institute of culture» (UlanUde city).

14. Kirillova Nataliya Konstantinovna, Ph.D. in Engineering, associate professor of the department of Restoration and Examination of Cultural Objects, HSBEI HE «Saint Petersburg state institute of culture» (Saint Petersburg city)

15. Mansheeva Soelma Tsydypovna, associate professor of the department of Ethnology and Folk Artistic Culture, FSBEI HE «East Siberian state institute of culture» (Ulan-Ude city). 
16. Nazarov Viktor Kuzmich, Ph.D. in Pedagogy, associate professor of the department of Culturology and Art History, FSBEI HE «East Siberian state institute of culture» (Ulan-Ude city).

17. Nemchinova Tamara Alexandrovna, Ph.D. in History, associate professor, chief of the Training and Doctrine department, FSBEI HE «East Siberian state institute of culture» (Ulan-Ude city).

18. Orlov Leonid Georgievich, Ph.D. in History, associate professor, honored professor, FSBEI HE «East Siberian state institute of culture» (Ulan-Ude city).

19. Reshchikov Nikolay Ivanovich, associate professor of the department of Choral Conducting, Sound Directing and Vocal Art, FSBEI HE «East Siberian state institute of culture» (Ulan-Ude city).

20. Solntseva Galina Nikolaevna, associate professor of the department of Design, FSBEI HE «East Siberian state institute of culture» (Ulan-Ude city).

21. Timoshenkova Anastasia Maximovna, 1st-year magistrate, specialization «Restoration of the Decorative and Applied Art Works», HSBEI HE «Saint Petersburg state institute of culture» (Saint Petersburg city).

22. Khobrakova Lyudmila Matveevna, Ph.D. in Philology, associate professor, chief of the department of Foreign Languages and General Linguistics, FSBEI HE «East Siberian state institute of culture» (Ulan-Ude city).

23. Tsyrempilova Irina Semyonovna, Sc.D.in History, associate professor, vice-rector in charge of scientific work, FSBEI HE «East Siberian state institute of culture» (Ulan-Ude city).

24. Shoibonova Sayana Viktorovna, Ph.D. in Philology, associate professor of the department of Literature and Linguistics, HSBEI HE «Saint Petersburg state institute of culture» (Ulan-Ude city). 


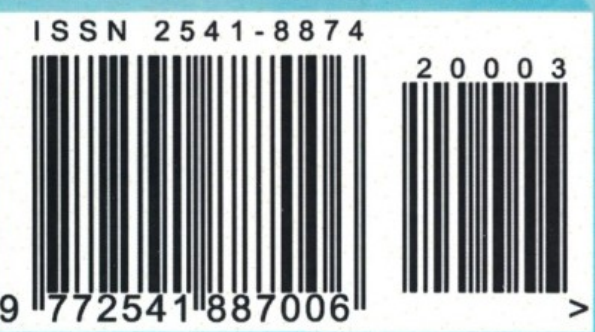

